AGRICULTURAL BUFFER CRITERIA

FOR THE CITY OF ARROYO GRANDE

\author{
A Professional Project \\ Presented to the Faculty of \\ California Polytechnic State University \\ San Luis Obispo
}

\begin{abstract}
In Partial Fulfillment
of the Requirements for the Degree of

Master of City and Regional Planning
\end{abstract}

Prepared by:

Laura A. Pennebaker

May 2009 
(C)2009

Laura A. Pennebaker

ALL RIGHTS RESERVED 
COMMITEE PAGE

TITLE:

AGRICULTURAL BUFFER CRITERIA FOR THE CITY OF ARROYO GRANDE

AUTHOR: $\quad$ LAURA PENNEBAKER

DATE SUBMITTED: $\quad$ MAY 2009

COMMITTEE CHAIR: Paul Wack, AICP

COMMITTEE MEMBER: Adrienne Greve

COMMITTEE MEMBER: Teresa McClish, AICP 


\section{ABSTRACT \\ AGRICULTURAL BUFFER CRITERIA FOR THE CITY OF ARROYO GRANDE}

\section{LAURA A. PENNEBAKER}

The conservation of agricultural land is an important and challenging part of local and regional planning. Prime agricultural soils and viable agricultural operations serve as a vital part of California's identity and economy. The conversion of land from farming to non-agricultural use significantly increases the potential for conflict between adjoining land uses and intensifies the pressure to develop adjacent farmland. Agricultural buffers serve as a tool to mitigate potential conflict between adjacent non-compatible land uses and protect both farming operations and residents from nuisance complaints.

The City of Arroyo Grande has agricultural buffer policies which apply to development taking place adjacent to agricultural land. The City’s general plan requires a minimum100 foot buffer between all parcels proposed for non-agricultural development adjacent to agricultural land. The buffer area is also required to contain a minimum 20 foot wide landscaped area. City policy however, does not provide any specific direction or criteria regarding the actual construction of an agricultural buffer. The purpose of this project is to evaluate agricultural buffer policies present in other jurisdictions throughout California and determine appropriate criteria for the construction and maintenance of an agricultural buffer in the City of Arroyo Grande.

The project involves literature review as well as review of general plan and development code policies throughout California. The project concludes with a draft document entitled Criteria for Agricultural Buffers in the City of Arroyo Grande which includes agricultural buffer specifications such as plant palette and planting density which will be incorporated by reference into the City of Arroyo Grande Municipal Code. 


\section{ACKNOWLEDGMENTS}

I greatly appreciate the support and encouragement of the following individuals who assisted in the review and completion of this research:

\section{Adrienne Greve, Ph.D. Professor}

Teresa McClish, AICP

Paul Wack, AICP, Professor

Kaila Dettman

and

William Pennebaker 


\section{Table of Contents}

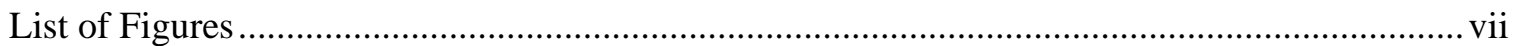

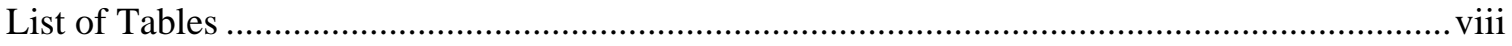

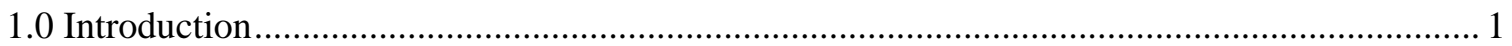

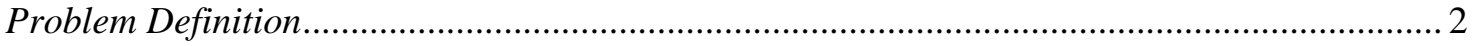

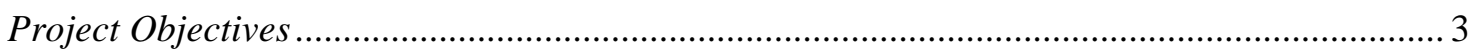

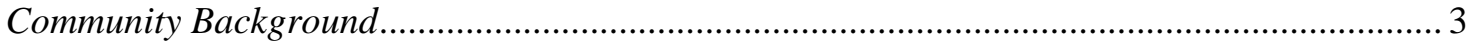

2.0 Current City of Arroyo Grande Agricultural Buffer Practices.................................................. 9

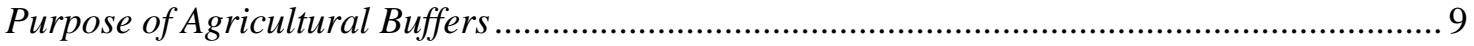

History of Agricultural Land Conservation, Buffer Policies and Practices ............................... 9

Current Issues and Opportunities for Analysis ........................................................................ 11

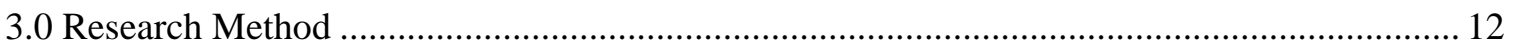

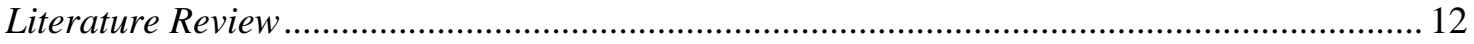

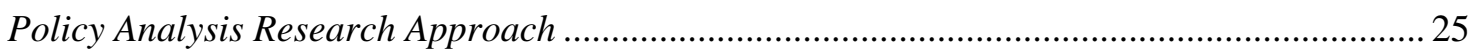

4.0 Policy Analysis of Agricultural Buffer Practices Throughout California................................ 27

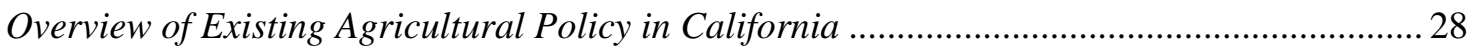

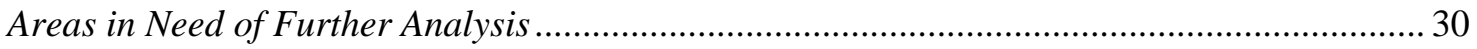

5.0 Policy Analysis of Specific Jurisdiction Buffer Practices....................................................... 31

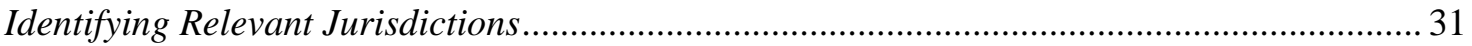

Identifying Effective Agricultural Buffer Policies.................................................................. 32

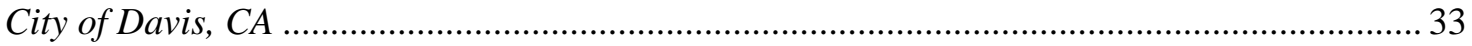

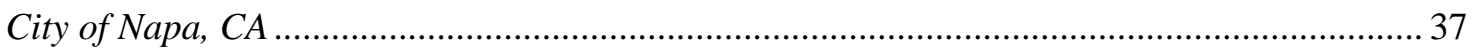

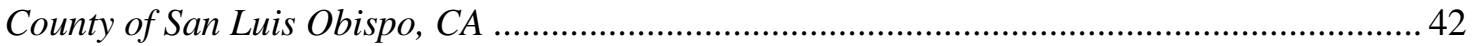

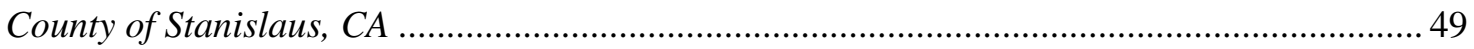

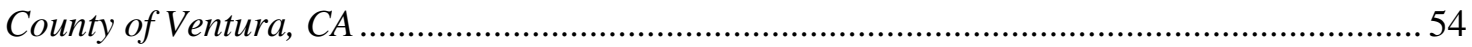

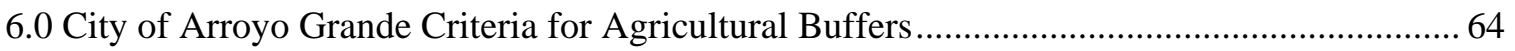

Strengths and Weaknesses of Arroyo Grande Agricultural Buffer Criteria ............................... 64

Draft Agricultural Buffer Criteria for the City of Arroyo Grande ............................................ 67

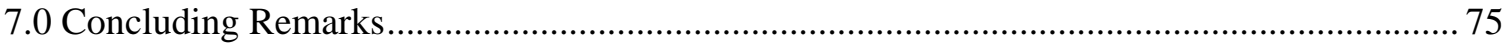

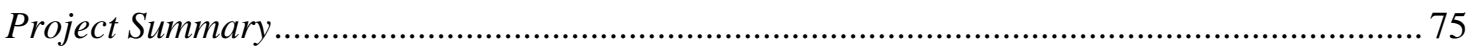

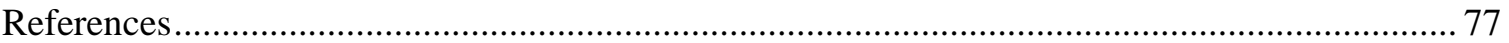

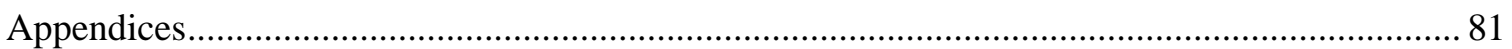




\section{List of Figures}

Figure 1.0 - Aerial view of Arroyo Grande City Limits ........................................................... 4

Figure 1.1 - Agricultural Landscape in Arroyo Grande ............................................................. 6

Figure 1.2 - Agricultural Urban Interface in Arroyo Grande ................................................. 6

Figure 1.3 - Class I and II Soils in Arroyo Grande ................................................................... 7

Figure 1.4 - Arroyo Grande Agriculture: Zoning and Land Use............................................. 7

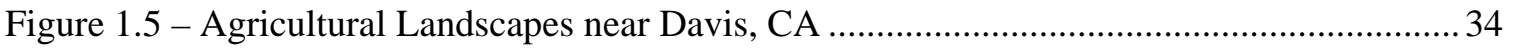

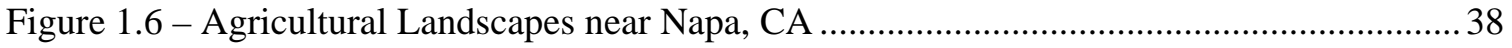

Figure 1.7 - Agricultural Landscapes in San Luis Obispo County CA ...................................... 43

Figure 1.8 - Agricultural Landscapes in Stanislaus County CA ….............................................. 49

Figure 1.9 - Agricultural Landscapes in Ventura County CA....................................................... 55

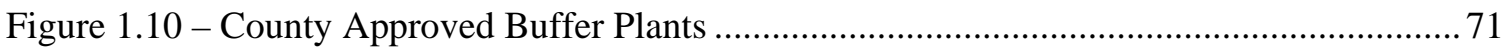

Figure 1.11 - Example Minimum Buffer Schematic .................................................................... 73

Figure 1.12 - Example Moderate Buffer Schematic....................................................................... 73

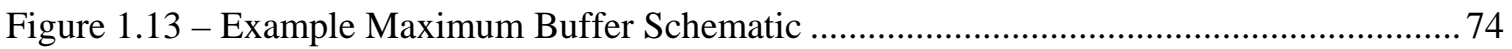




\section{List of Tables}

Table 1.0 - General Policy Review Jurisdictions ...................................................................... 27

Table 1.1 - Buffer Policy in the City of Davis General Plan........................................................ 35

Table 1.2 - Buffer Policy in the City of Davis Municipal Code.................................................... 36

Table 1.3 - Buffer Policy in the City of Napa General Plan......................................................... 39

Table 1.4 - Buffer Policy in the City of Napa Municipal Code .................................................. 40

Table 1.5 - Buffer Policy in the San Luis Obispo County General Plan ..................................... 44

Table 1.6 - Buffer Policy in SLO County General Plan Appendix D .........................................46

Table 1.7 - Buffer Distance Policy in SLO County General Plan Appendix D ........................... 47

Table 1.8 - Buffer Policy in the Stanislaus County General Plan ................................................50

Table 1.9 - Stanislaus County Agricultural Buffer and Setback Guidelines ................................ 51

Table 1.10 - Additional Stanislaus County Agricultural Buffer and Setback Guidelines.............. 52

Table 1.11 - Buffer Policy in the Ventura County General Plan.................................................... 56

Table 1.12 - Ag Futures Alliance Buffer Principles and Recommendations ............................... 58

Table 1.13 - Ventura County Agricultural/Urban Buffer Policy - Design ................................... 60

Table 1.14 - Ventura County Agricultural/Urban Buffer Policy - Use ........................................ 61

Table 1.15 - City of Arroyo Grande Agricultural Principles and Objectives............................... 64

Table 1.16 - City of Arroyo Grande General Plan Buffer Policy .................................................... 65 
Chapter 1

\subsection{Introduction}

Agricultural land represents a resource that is irreplaceable and therefore must be protected and preserved. Productive farmland provides a source of food, fiber and livelihood. In the state of California, a very large and diverse agricultural system must coexist with an extensive urban population. Competition for resources between agricultural production and urban development is rampant, tension is inevitable and values often differ significantly between land

users. Urban residents and local government officials tend to value farmland as a scenic resource while other demographics including farmers value agricultural land as an economic resource and source of livelihood. As urban development continues in California, farmers will continue to be forced to adjust production practices to accommodate nearby residential uses and residents living near farmland will need to adjust to living on the urban edge.

Without proper regulation of residential or commercial development adjacent to agricultural land, the potential for conflict between land uses is significant. Common negative impacts associated with agricultural production have been identified as air, soil and water pollution \& nuisance such as the presence of lights, noise and odor (Copprock and Kreith, 1997 and Hammond, 2002). Common negative impacts associated with commercial or residential uses adjacent to agriculture include litter, introduction of pests, vandalism, increased liability, farming restrictions and loss of profit (Copprock and Kreith, 1997 and Hammond, 2002).

Municipalities have legal authority to regulate development to protect resident health, safety and general welfare. The regulation of development adjacent to agricultural land to reduce conflict generally takes the form of an agricultural buffer. The implementation of agricultural buffer policy requires a careful balance of 1.) scientific basis for determination of buffer distances 2.) visual and aesthetic buffer components and 3.) consideration of how buffer construction may affect farming practices and quality of life for adjacent residents (Hammond, 2002). 


\section{Problem Definition}

The City of Arroyo Grande is one of few cities remaining in California with productive agricultural lands within the city limits. Most cities and counties focus agricultural preservation efforts on conserving agricultural resources outside the urban area. The City of Arroyo Grande has chosen to protect and sustain its urban agriculture and promote working agricultural landscapes within its jurisdictional boundaries without relying solely upon county regulations to preserve farmland. In December 2003 the Arroyo Grande City Council approved Ordinance 550 which established farmland preservation buffers and created an Agricultural Preservation Overlay District placing a 100-foot perimeter around agriculturally zoned properties within the City and incorporating new regulations for development proposed adjacent to agricultural zoning districts. Since that time, several questions and issue areas have arisen relating to the interpretation of current agricultural buffer policies specifically regarding location of, planting density and plant palette within an agricultural buffer.

When applying agricultural buffer policies to a proposed project, the public, elected officials and City staff have the following resources: the 2001 City of Arroyo Grande General Plan Conservation and Open Space Element Agriculture Objectives and Policies (amended March 23, 2004) as well as Chapter 16 Section 12.170 of the Municipal Code. These policies do not provide any minimum planting density requirements or recommended plant species. In an effort to help City staff, elected officials and the public understand and comply with the agricultural buffer requirements, development of specific criteria for the construction and maintenance of an agricultural buffer in the City of Arroyo Grande is necessary.

The agricultural buffer criteria document should provide specific criteria including: minimum buffer setback width, minimum vegetation buffer width and placement, minimum planting density, appropriate plant species, permitted uses within the buffer and maintenance requirements. 


\section{Project Objectives}

The end product is a document entitled Criteria for Agricultural Buffers in the City of Arroyo Grande which is contained in Chapter 6. This document shall be clear, easy to

understand, and consistent with the City of Arroyo Grande General Plan and current City, County, State and Federal regulations. The objectives of the project are to:

- Examine the literature and issues regarding agricultural buffer effectiveness and design.

- Conduct a policy review of General Plan and Zoning/Development Code documents for five jurisdictions to determine setback and vegetative screening criteria used.

- Draft agricultural buffer criteria to be incorporated by reference into the City of Arroyo Grande Municipal Code.

\section{Community Background}

The City of Arroyo Grande occupies approximately 5.45 square miles of land along U.S. Highway 101 in Southwestern San Luis Obispo County (City of Arroyo Grande, 2004). Figure 1.0 below illustrates an aerial view of the City limits. 
Figure 1.0 - Aerial view of Arroyo Grande City Limits

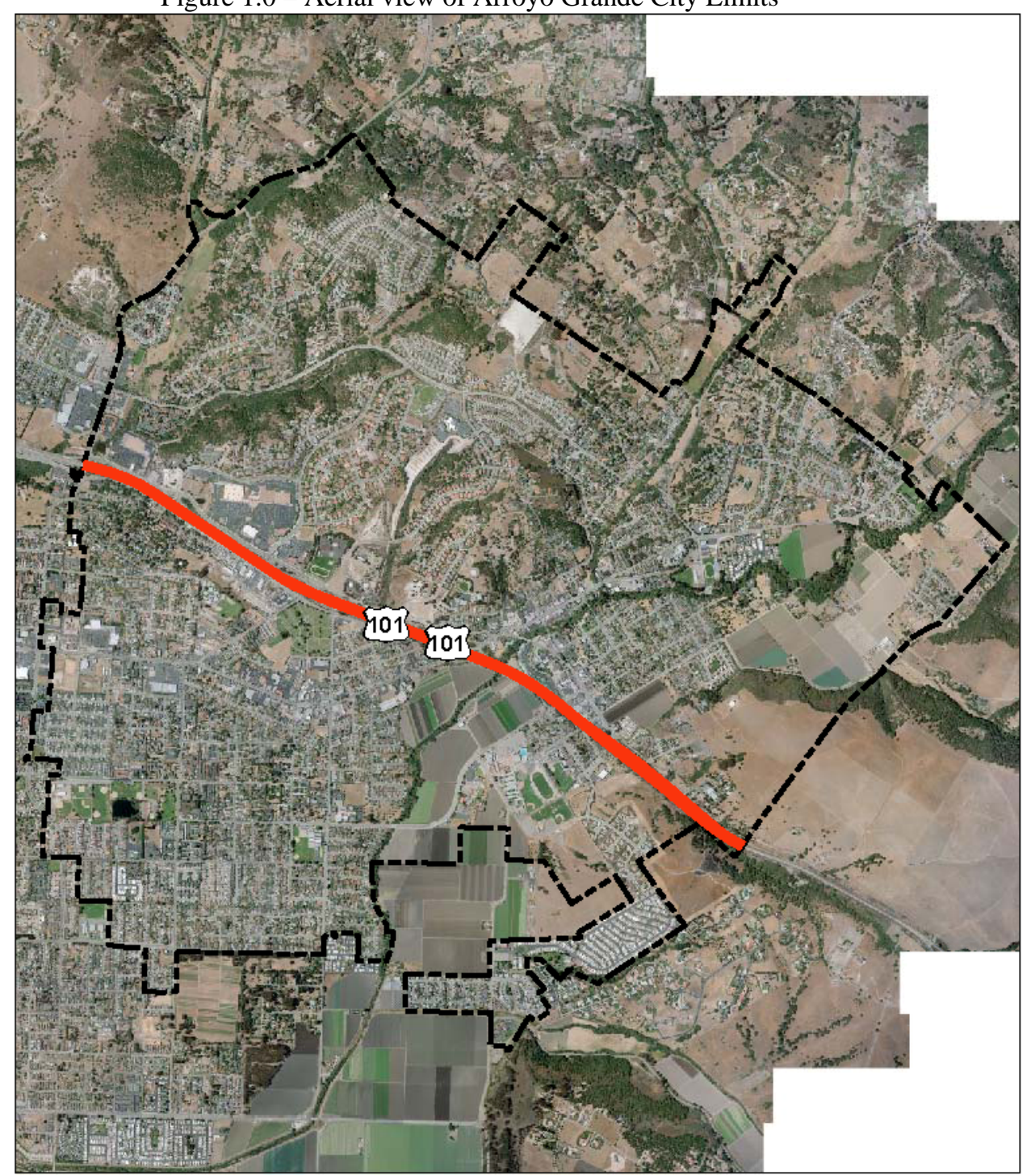

Source: City of Arroyo Grande, 2009

It is immediately bounded to the west and southwest by urban development within the Cities of Pismo Beach, Grover Beach and the unincorporated community of Oceano.

Unincorporated lands adjoin the City to the north, east and south and are characterized by rural residential and suburban development. Agriculture uses dominate the Arroyo Grande Valley that extends northeast of the City limit and the La Cienega Valley which runs south of the City. Arroyo Grande Creek runs in a generally north-south direction through the eastern portion of the City. 
According to the California Department of Finance, the City of Arroyo Grande is home to 17,036 residents (CA Department of Finance, 2008). Current estimates from the San Luis Obispo County Council of Governments project the City’s General Plan “build-out” population to be 19,000 - 20,000 residents by 2023 (City of Arroyo Grande General Plan, 2001).

The Arroyo Grande Valley and La Cienega Valley comprise approximately 2,500 acres of land along Arroyo Grande Creek. There are 25 soil types present in the Arroyo Grande region, 12 types (roughly 91\% of the area) are classified as prime agricultural soils (City of Arroyo Grande, 1997). According to the Coordinated Agricultural Support Program (CASP) summary report published in 1997:

The Arroyo Grande Valley contains some of the world's most productive agricultural land. Its deep soils, combined with adequate irrigation and frost-free climate have yielded abundant quantities of fruits and vegetables for over a century. In 1994, the fertile soils in the Arroyo Grande Valley yielded approximately \$24 million in agricultural value, primarily row crops. (City of Arroyo Grande, 1997, p.1)

The Arroyo Grande region is world renown for its production of cool season vegetable and row crops including lettuce, cauliflower, broccoli, celery, cabbage and strawberries. Intense commercial vegetable production is conducted through the Valley by third and even fourth generation producers (City of Arroyo Grande, 1997). Production is augmented by local cooling, storage and shipping facilities including the Pismo Oceano Vegetable Exchange which facilitates the movement of local produce to a nationwide market. Figures 1.1 and 1.2 below illustrate agricultural landscapes in the Arroyo Grande Valley region. 
Figure 1.1 - Agricultural Landscape in Arroyo Grande

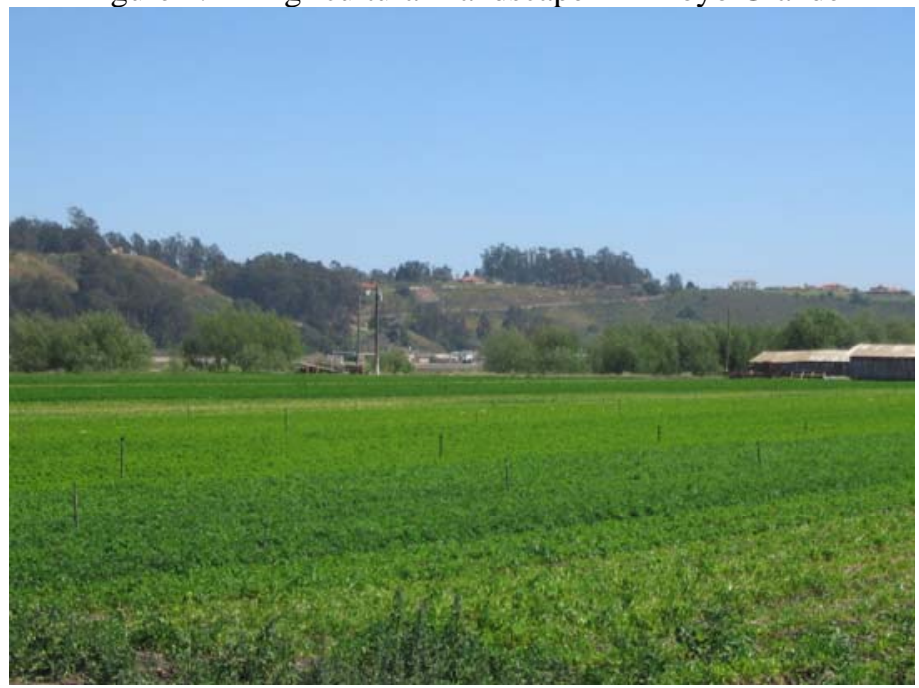

Source: City of Arroyo Grande 2008

Figure 1.2 - Agricultural Urban Interface in Arroyo Grande

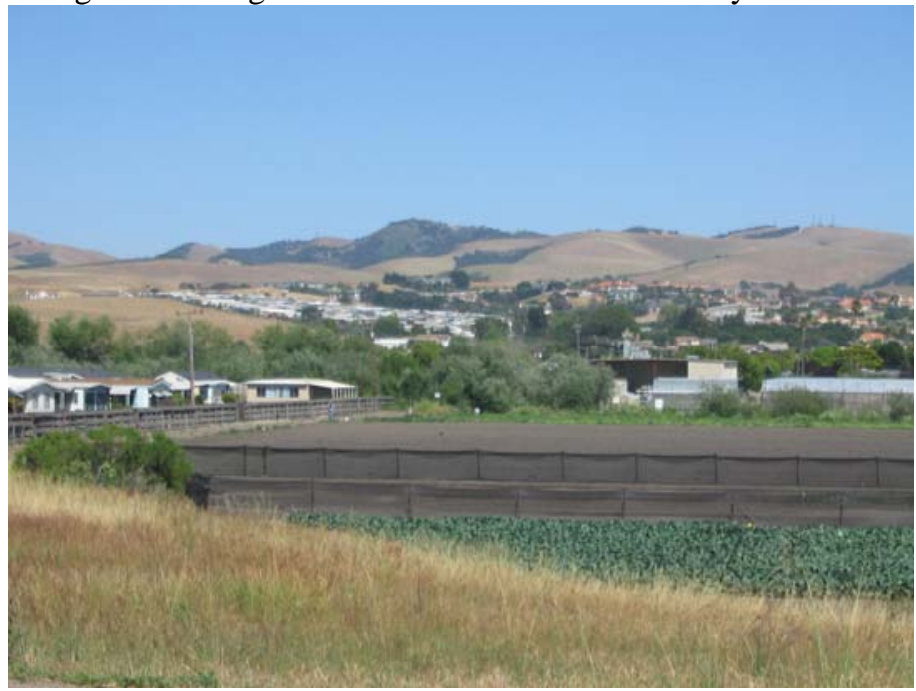

Source: City of Arroyo Grande 2008

The City of Arroyo Grande is unique in that it contains approximately 369 acres of land zoned Agriculture within City limits, and approximately 500 acres of Class I and II soils. Figures 1.3 and 1.4 below illustrate the presence of Class I and II soils within the City limits and parcels with agricultural land use and zoning designations. 
Figure 1.3 - Class I and II Soils in Arroyo Grande

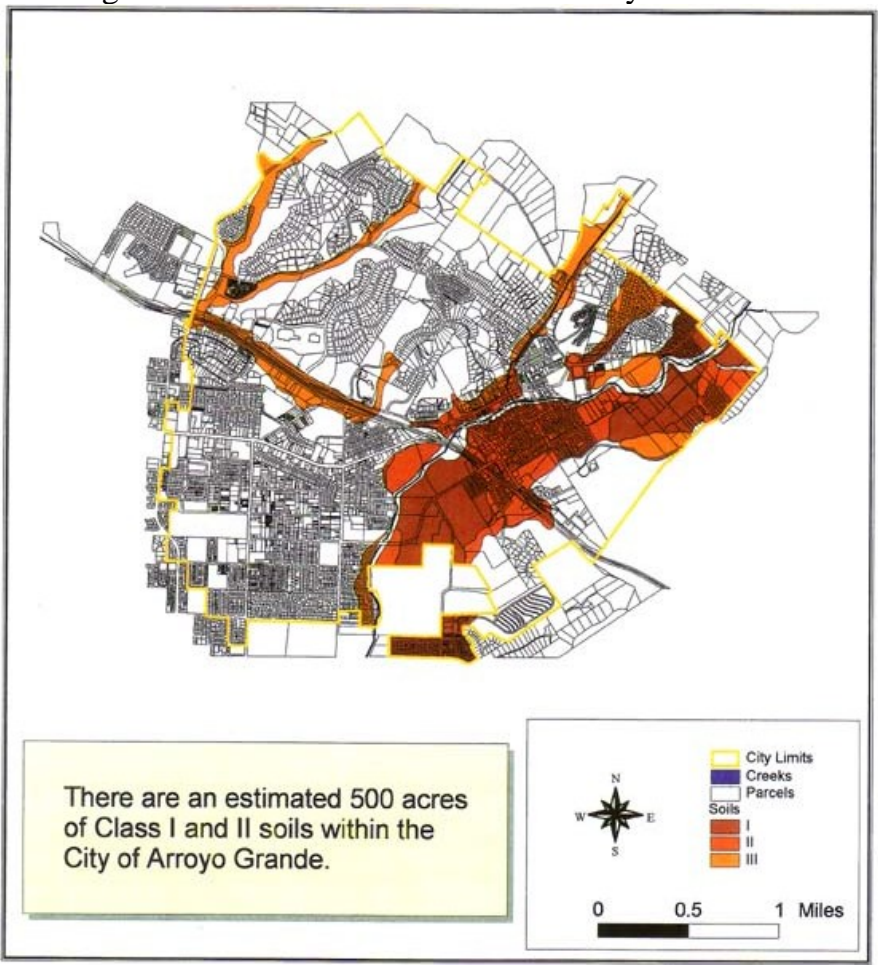

Source: City of Arroyo Grande 2001

Figure 1.4 - Arroyo Grande Agriculture: Zoning and Land Use

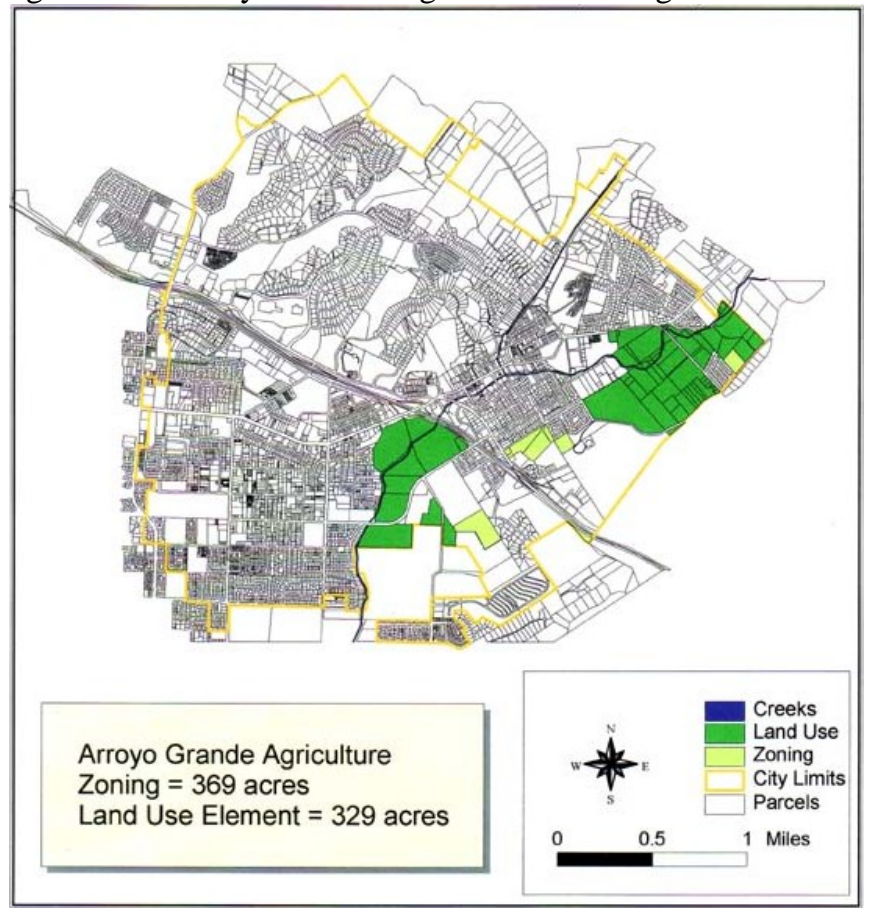

Source: City of Arroyo Grande 2001 
The City has a long history of preserving farmland which has included strong policies in the General Plan and Municipal Code, support of a study for the City in 1997 called The Coordinated Agricultural Support Program (CASP) as well as the development of policies to protect urban agriculture within the community which is further detailed in Chapter 2. 


\section{Chapter 2}

\subsection{Current City of Arroyo Grande Agricultural Buffer Practices}

\section{Purpose of Agricultural Buffers}

Agricultural buffers serve to protect the long term health of local agriculture by minimizing conflicts resulting from normal agricultural practices as a consequence of new or expanding non-agricultural uses adjacent to agriculturally zoned land (Stanislaus County, 2007). An agricultural buffer is defined as a physical separation between residential and agricultural uses of land which can consist of a topographic feature, a substantial stand of trees, a watercourse or other similar feature that serves to protect or insulate one type of land use from another (Hammond, 2002 and Stanislaus County, 2007).

\section{History of Agricultural Land Conservation, Buffer Policies and Practices}

The City of Arroyo Grande has historically been proactive in the conservation of agricultural resources within the City limits. On January 14, 2003, in response to increasing pressure to convert prime agricultural lands to non-agricultural uses, the City Council adopted Ordinance No. 536 suspending the acceptance of development applications for land containing prime farmland soils. Beginning in May 2003, a series of public workshops and meetings were held to solicit public input on policies protecting agriculture. In July 2003 the City Council adopted Resolution 3699 to implement specific recommendations from staff research and public input including:

- the initiation of an amendment to the General Plan Land Use Map;

- an amendment to certain policies of the General Plan;

- the establishment of agricultural conservation easement and support programs and;

- an amendment to the Municipal Code modifying allowable uses and standards in agricultural districts and establishing mitigation measures and a buffer overlay district.

In September 2003, the City Council adopted Resolution 3711 that approved General Plan amendment 03-002 which included changing the land use designation of four parcels to 
agriculture, modifying language in the Land Use Element and amending the Agriculture, Conservation and Open Space Element to revise implementation policy for mitigation of converted agricultural lands. In December 2003 the Arroyo Grande City Council approved Ordinance 550 incorporating regulations and amending the Zoning Map to create an Agricultural Preservation Overlay District placing a 100-foot perimeter around agriculturally zoned properties and incorporating new regulations for development proposed adjacent to Agricultural zoning districts. When applying agricultural buffer policies to a proposed project, the public, elected officials and City staff have the following resources: the 2001 City of Arroyo Grande General Plan Conservation and Open Space Element Agriculture Objectives and Policies (amended March 23, 2004) as well as Chapter 16 Section 12 of the Municipal Code. General Plan and Municipal Code policies are available in Appendix A.

Current basic agricultural buffer requirements (as outlined in the General Plan and Municipal Code) for the City of Arroyo Grande include:

- The provision of a minimum 100 foot agricultural buffer on all parcels proposed for nonagricultural development adjacent to agricultural uses.

- The buffer area shall be noticed and/or fenced and landscaped in such a manner to discourage human and domestic animal trespass and screen urban uses from dust and wind borne materials.

- The buffer must contain a minimum 20 foot landscaped transition area with plantings sufficiently dense and mature to provide aerosol protection within the first year of establishment. Pedestrian access is allowed in the landscaped transition area.

- Adjacent to the minimum 20 foot landscaped transition area, a minimum 80 foot agricultural buffer is required which is adjacent to the agricultural district.

- No portion of any new residential structure within a non-agricultural land use designation shall be located within 100 feet from the site of agricultural operations (restoration or remodel of existing homes is allowed).

- Permitted uses in the agricultural buffer include: native plants, trees or hedgerows, roads, drainage channels, storm retention ponds, natural areas i.e. creeks or drainage swales, utility corridors, storage, and any use (including agricultural, limited commercial or low intensity human uses) determined by the Planning Commission to be consistent with the use of the property as an agricultural buffer.

- Greater buffer distances may be required based upon site-specific circumstances. 


\section{Current Issues and Opportunities for Analysis}

In October 2004, the City Council considered an interpretation of the Agricultural Buffer provision from Ordinance 550, specifically related to residential uses within the buffer area including the location of backyards within the buffer area as well as the maintenance requirements for new buffers and the location of the 20 foot landscaped transition area within the 100 foot buffer area. The City Council rendered the following interpretation:

- No new residential uses (including backyards and garages associated with residential uses) are allowed within the 100 foot minimum buffer.

- New buffer areas are to be maintained by either a homeowners association, a maintenance district, or dedicated to the City for new residential uses.

- Flexibility regarding the location of the 20 foot landscape strip within the 100 foot minimum buffer is allowed with a preference for keeping the landscape strip as far away from agricultural operations as possible.

Since that time additional questions and issue areas have arisen relating to the interpretation of agricultural buffer policies specifically regarding planting density and plant palette within an agricultural buffer. Current policies do not provide any minimum planting density requirements or recommended plant species. In 2007, City Council asked for additional review and discussion of City buffer policy to investigate further amending the development code to address allowable non-residential uses within agricultural buffers as well as overall buffer construction. It was determined in January 2008 that City staff resources would not permit extensive re-visitation of the buffer policy guidelines and that the issue should marketed as a student intern project. In October 2008 this Professional Project began to investigate literature and policy for recommendations regarding the construction of an agricultural buffer in Arroyo Grande and the development of buffer criteria which will serve to augment existing General Plan and Municipal Code requirements and provide general guidance for staff, decision makers and the public. 


\section{Chapter 3}

\subsection{Research Method}

To facilitate the research associated with this project, the review is classified into two categories: literature and policy. The literature review reveals existing scientific and public policy publications from available resources. The policy review serves to document agricultural buffer requirements present in jurisdictions throughout California. The research consists of review of scientific and public policy literature to determine a scientific basis for agricultural buffer criteria as well as general plan and development code review to determine agricultural buffer criteria in place throughout California. Criterion were then developed to a.) select jurisdictions which have similar location, climate, topography and crop production for further analysis of agricultural buffer practices and b.) evaluate the buffer policies of these similar jurisdictions to identify effective buffer practices using criteria developed by Sonya Hammond and the Great Valley Center. Research concludes with the development of Criteria for Agricultural Buffers in the City of Arroyo Grande (See Chapter 6).

\section{Literature Review}

Common impacts associated with agricultural production have been identified in literature as air, soil and water pollution \& nuisance such as the presence of lights, noise and odor (Copprock and Kreith, 1997 and Hammond, 2002). Agricultural buffers are generally defined as “physical separations between residential and agricultural uses of land” (Hammond, 2002, p.7) and have been scientifically proven to reduce air, soil and water pollution impacts (Dosskey 2002, Lowrance et al. 2002, Owens et al. 2007, Popov et al. 2006, Sullivan and Lovell 2006, Vought et al. 1995). Buffers can take on several forms including setbacks, installed barriers, existing topographic features, building requirements or restrictions, recreational areas and modified agricultural uses (Hammond, 2002, p.11). In addition to the reduction of air, soil and water 
pollution, buffers have also been proven to provide aesthetic benefits and have been determined to be visually preferable by rural urban interface stakeholders (Handel 1994, Nassauer, 1989, Ryan 2002, and Sullivan et al. 2004).

Much of the scientific research identifying the pollution prevention functions of agricultural buffers focuses on the use of vegetation to mitigate impacts to air, soil and water quality (Dosskey 2002, Lowrance et al. 2002, Owens et al. 2007, Popov et al. 2006, Sullivan and Lovell 2006, Vought et al. 1995); however, there is very little research which details the efficacy of buffers in reducing conflict between agriculture and adjoining land uses. Several studies in the Midwestern United States have clearly documented agroforestry buffers which serve to reduce sediment and nutrient transport between agricultural land and adjacent natural systems such as streams or wetlands (Dosskey et al., 2002, Lowrance et al., 2002, and Owens et al., 2007). Additionally extensive research has been conducted in Europe and Australia indicating that the presence of in-field vegetative biostrips reduces transport of sediment born pesticide particles (Popov et al., 2006 and Vought et al., 1995). Field studies conducted in the Hollandse Delta in South Holland measured surface water emissions from agricultural fields containing mandatory vegetative buffers and found that buffer strips reduced nutrient emission to surface water by 50 89\% and pesticide emissions by 75 - 95\% (Sloots and Van der Vlies, 2007). Studies in Holland also determined that field buffers reduced pesticide use by serving to harbor beneficial insects (Sloots and Van der Vlies, 2007).

In addition to the body of research which has evaluated impacts to soil, air and water quality, considerable study has been dedicated to the determining the ability of vegetative buffers to reduce off-target pesticide spray drift from agricultural operations. The majority of compiled pesticide spray drift research is available through the Spray Drift Task Force (SDTF). The SDTF was developed in 1990 in partnership with the US Environmental Protection Agency Office of Pesticide Programs to provide information and a depository for spray drift research (Spray Drift 
Task Force, 1997). Pesticide drift research is subject to a number of confounding variables including type of crop production, type of product used, spray method and droplet size, as well as climatic and wind conditions. Airblast and ground pesticide application studies in the Netherlands found that vegetation can significantly reduce drift from spray application to orchards and row crops (Zande et al., 2004). Field studies conducted to determine the effect of trees as buffer zones for the interception of pesticide found that the minimum height of the vegetative barrier should be 1.5 times the spray release height (Spillman and Woods, 1989). Research also determined that dense vegetative barriers can direct wind flow up and over the barrier reducing drift filtration, while more porous barriers direct more airflow through the barrier rather than over it, thus increasing filtration (Spillman and Woods, 1989). Additional field studies have also determined that very dense field margin vegetation will not allow adequate air flow through the buffer canopy (Miller and Lane, 1999).

Using multiple rows of vegetation was found to allow for an increase in the amount of spray catching surfaces within the buffer while minimizing air flow deviation over the buffer and $40-50 \%$ porosity was determined to be the optimum level for spray interception (Dorr et al., 1998). Research conducted by the U.S. Department of Agriculture found that conifer foliage was effective in catching small pesticide droplets (Barry, 1984). The study of vegetative buffer zones for drift reduction in Australia found that trees and shrubs with small needle-like leaves or stems were more efficient at removing small pesticide droplets (Voller, 1999). Research has also indicated that minimum vegetative barrier height should be 1.5 times spray release height (Spillman and Woods, 1989 and Voller, 1999). Consensus in the literature suggests that significant reduction in pesticide spray drift can be attributed to the use of multiple rows of vegetation with some conifer composition and approximately 50\% porosity.

While the presence of scientific literature studying the efficacy of agricultural buffers to reduce impacts on soil, air, water quality and pesticide drift, literature studying the efficacy of 
buffers to mitigate actual conflict between farming and non-agricultural uses is minimal. However, several municipalities in Australia and Canada have published policy papers which build upon field studies to evaluate existing buffer policies and recommend setback, vegetation, and design strategies which can serve to reduce conflict at the urban/rural edge. Additionally, non-profit organizations in the United States including the Great Valley Center in California, have published policy papers which serve to evaluate issues associated with the agricultural/urban interface and provide guidance to municipalities seeking to improve upon or establish new agricultural buffer policies. Policy papers were evaluated to determine buffer recommendations for reducing conflict associated with pesticide drift, dust/odor, and noise.

The Provincial Agricultural Land Commission of British Columbia (PALC) was one of the first entities to develop recommendations for agricultural buffers in western Canada. In 1993 the PALC published Landscaped Buffer Specifications which served to provide a practical guide for councils, regional boards, and other agencies where the opportunity exists to create or improve the buffer between agricultural and non-agricultural land. Landscaped Buffer Specifications sets out a graduation of buffer types ranging from simple vegetation screens to comprehensive buffers incorporating berms, fencing and planting for the screening of noise, views, dust and sprays. This graduation of buffer types is applicable to Arroyo Grande’s small agricultural parcel setting as it offers a range of buffer screening features. The report identifies four main recommended buffer types:

1.) Minimum Vegetative Screen - provided minimum visual screening and protection of farmland from trespass/vandalism. Design features entail:

- Minimum buffer width of 10 feet unless otherwise determined.

- Minimum double row of trespass inhibiting shrubs.

- Minimum single row of coniferous/broadleaf evergreen hedge.

- Fencing. 
2.) Minimum Vegetative Screen (Medium Height Trees) - inhibits trespass/vandalism while providing minimum protection to non-farm developments from the movement of dust and pesticide spray from adjacent farm operations. Design features include:

- Minimum buffer width 20 feet unless otherwise determined.

- Minimum single row deciduous trees.

- Minimum triple row trespass inhibiting shrubs.

- Minimum single row screening shrubs.

- Minimum distance from shared property line to first row of trees should be 10 feet.

- Fencing.

3.) Airborne Particle and Visual Screen - inhibits trespass/vandalism while offering greater physical setback between land uses, visually screening uses from one another and minimizing the exchange of undesirable airborne particulate matter. Design features entail:

- Minimum buffer width 50 feet (minimum distance from shared property line to the first row of trees is 16 feet).

- A.) Yearly Screen - minimum double row of deciduous and coniferous trees.

- B.) Summer Screen - minimum double row of screening shrubs.

- Additional shrubs and/or groundcover as specified.

- Fencing.

4.) Noise, Airborne Particle, and Visual Screen - buffers agricultural land from trespass/vandalism as well as visually screening incompatible uses, reducing the exchange of particulate matter and reducing noise transmission. Design features entail:

- Minimum buffer 66 feet unless otherwise specified.

- A.) Yearly Screen - minimum double row deciduous and conifer trees.

- B.) Summer Screen - minimum double row deciduous trees.

- Minimum distance from shared property line to first row of trees is 16 feet.

- Minimum berm height should be 6 feet above adjacent grades plus fencing at the top.

- On non-agricultural side of the berm there should be a minimum double row of screening shrubs and a minimum triple row of trespass inhibiting shrubs.

The Department of Natural Resources, Local Government and Planning (DNRLGP) in Queensland Australia published the policy paper Planning Guidelines: Separating Agriculture 
and Residential Land Uses, in 1997 which provides technical advice and guidance on reducing the potential for conflict between farming activities and residential development. The Planning Guidelines are considered to be a foundational work regarding buffer design specifications and are incorporated by several jurisdictions throughout California in agricultural buffer policy recommendations. DNRLGP cites buffer areas as legitimate planning tools to separate conflict generating land uses which may help contribute to conservation of agricultural land and production. In the Planning Guidelines, DNRLGP introduces the concept that complaints from agricultural production are often based as much on perception as reality particularly in relation to chemical spray drift and thus determined that,

... a suitable visual barrier between development and agricultural land in the form of a vegetation screen can significantly reduce the level of complaint by minimizing the cause and perception of the nuisance. (DNRLGP, 1997, p.2).

Vegetative components alone may not be enough to properly buffer residential development from farming practices; however, DNRLGP concluded that vegetative screening used in conjunction with other buffering techniques may serve to reduce the incidence of nuisance complaints and promote coexistence between adjoining land uses.

DNRLGP recommends that conflict assessment be conducted at the predevelopment phase to establish separation requirements and buffer area design including determination of 1.) type of agricultural production, 2.) the presence of natural buffer features, 3.) presence of sensitive receptors, 4.) type and method of chemical application, 5.) wind speed and direction. Recommended buffer sizes will also vary based upon local topography and climate. DNRLGP determined based upon research conducted by J. Harden in 1992 that, “....negligible spray drift may exist at a separation distance of 300 meters (approximately 984 feet)” and vegetative buffers have been shown to be effective in capturing up to $80 \%$ of pesticide spray drift measured from application upwind of a single row of trees (DNRLGP, 1997, p. 9-10). The Planning Guidelines 
therefore recommend a general buffer width of 300 meters (984 feet) for open ground conditions and 40 meters (131 feet) where a vegetated buffer element can be installed and maintained.

DNRLGP also studied buffer requirements for odor, dust/smoke and noise generation associated with livestock production, farm machinery, and pest control devices. Recommended buffer distances to address odor and noise impacts include: 500 meters (1640 feet) for livestock odor and between 60 - 500 meters (196 - 1640 feet) for intermittent daytime noise and 1000 meters (3280 feet) for nighttime noise (DNRLGP, 1997, p. 14). Recommended buffer distances to address dust/smoke include 40 meters (131 feet) of vegetative screening or a 150 meter (492 feet) separation distance (DNRLGP, 1997, p. 17). The Planning Guidelines also outline elements of vegetated buffer design and recommend the following:

- Vegetated buffers should be a minimum total width of 40 meters (131 feet)

- Vegetated buffers should contain random plantings of a variety of tree and shrub species of differing growth habits spaced a $4-5$ meters $(13-16$ feet) for a minimum width of 20 meters (65 feet).

- Vegetated buffers should include species with long, thin, rough foliage (from the base to the crown) which facilitates the efficient capture of spray droplets.

- Vegetative buffers should provide a permeable barrier with roughly 50\% porosity (half of the vegetative screen should be air space).

- Vegetative buffers should contain species which are fast growing, hardy, and with a mature tree height of 1.5 times the spray release height or target vegetation height, whichever is taller.

- Vegetative buffers should contain species with mature height, dimensions, and characteristics which will not adversely affect adjacent crop lands (i.e. shading).

DNRLGP cites several advantages of vegetated buffers including: 1.) the creation of wildlife corridors and habitat, 2.) increased biological diversity which can assist in pest control, 3.) favorable microclimate influence, 4.) aesthetic value, 5.) recreation use opportunities, and 6.) reduction of noise and dust impacts.

The City of Abbotsford, British Columbia introduced a draft policy document entitled $A$ Landscape Buffering Strategy for the Agricultural-Urban Interface in July 2008. This document serves to outline a strategy for designing the interface areas between agriculture and urban uses in a rapidly growing area of 135,000 people in western Canada. The City of Abbotsford prefaces its 
agricultural buffer guidelines with policies directed at encouraging denser, more compact development at the urban core. A Landscape Buffering Strategy recommends similar characterization of urban/rural interface areas as recommended in The Planning Guidelines; however, the City of Abbotsford designated and mapped interface areas based upon: 1.) type of urban land uses present, 2.) type of agricultural production, and 3.) edge conditions present between the two land uses. Edge conditions include components such as streets and public rights of way, riparian areas and corridors, steep slopes or other topographic features, as well as urban/rural edges without any of these characteristics.

Five buffer types were developed to address the main types of edge conditions present at the periphery of Abbotsford pursuant to the Agricultural Land Commission of British Columbia's Landscape Buffer Specifications developed in 1993:

1.) Minimal Landscape Buffer - this design is appropriate where there is a minimal risk of conflict issues. Design elements of a minimal landscape buffer include:

- $\quad 10$ - 20 foot wide buffer containing;

- Planting of a 7 foot wide single row of trees with trespass inhibiting shrubs and;

- Fencing along the property line.

2.) Street Edge Buffer - this design is appropriate where the urban-agriculture edge is defined by a public road without a public trail or sidewalk on the agricultural edge. Design elements include:

- 10 - 20 foot wide buffer located closest to the agricultural production including;

- Planting of a single row of trees and trespass inhibiting shrubs or ditch/drainage swale and;

- Fencing maintained along the property line.

3.) Natural Edge Buffer - this design is appropriate where there is an existing or proposed natural edge buffer between urban and agricultural uses. Natural buffers generally take the form of riparian corridor and other topographical features. Design elements include:

- 50 - 100 foot wide buffer containing;

- Trails along the urban side of the buffer and; 
- Retention/augmentation of existing vegetation and management to ensure native understory condition and;

- Fencing along the property line and;

- Trail location, width, and fencing requirement as determined by environmental study.

4.) Moderate Landscape Buffer - this design is appropriate where there is a moderate risk of conflict between urban and agricultural land uses related to: trespass, nuisance complaints, traffics, light, noise or airborne dust. Typically these conditions exist where urban uses abut active farming areas. Design elements include:

- 25 - 50 foot wide buffer including;

- Planting of trespass inhibiting shrubs and a double row of trees;

- Trails along the urban side of the development and;

- Fencing along the property line.

5.) Maximum Landscape Buffer - this design is appropriate in particularly sensitive areas or where there is a significant risk of urban agricultural conflict. Including places with a high risk of trespass and a high risk that trespass will cause damage to farming operations at the urban edge. Design elements include;

- Minimum 50 foot wide buffer and;

- Water feature i.e. detention ponds, ditches and swales as appropriate;

- Trails along the urban side of the buffer only and;

- Planting of several rows of trespass inhibiting shrubs and 3 rows of trees;

- Berms and;

- Minimum 6 foot high solid fencing along the property line.

In addition to the five specific buffer types, the City of Abbotsford also recommends the following general requirements of landscaped buffers:

- Walkways and bike paths forming part of a buffer may constitute no more than $1 / 3$ of the buffer width, must be located away from the edge of the agricultural land, and must not reduce the effectiveness or primary purpose the landscaped buffer.

- Buildings and structures may not be built within buffer areas.

- Berms, detention ponds, ditches, and swales must be professionally designed and approved.

- Landscape plans shall show the location, size, condition, and species of all plant material proposed as well as details of existing vegetation to be retained and proposed fencing.

- Vegetation should be designed for a mature height of 20 feet with $60 \%$ maximum crown density and $60 \%$ minimum conifer composition. 
- Ultimately buffer design type will be determined based on site specific interface classification.

In September 2003 the British Columbia Ministry of Agriculture and Lands Resource Management Branch (BCMA) located in Abbotsford, published a study entitled, Vegetative Buffers in BC - An Investigation of Existing Buffers and their Effectiveness in Mitigating Conflict, which served to examine established and functioning vegetative buffers to better understand the effectiveness of different types of designs and to generate recommendations that could be used to improve existing buffer guidelines. The investigation involved physically assessing 27 vegetative buffers to determine species composition, height, crown width, crown density, physical gaps, separation from adjacent properties and overall health of the buffer. Presence of fences, ditches, berms, and irrigation systems were also noted. Consultation with individuals on both sides of the buffer was also conducted and included 60 interviews which provided information regarding the purpose of, installation details, cost of and maintenance activities conducted on the buffer.

The BCMA study revealed common problems associated with vegetative buffers including bird and rodent pests, insects and weeds, unwanted shading, inadequate separation between the buffer and neighboring fields or homes as well as vegetation comprised of well-established deciduous trees. The study also revealed benefits provided by the buffers including the ability of vegetative buffers to reduce urban and agricultural related impacts. Buffers were found to provide the following benefits to agricultural and non-farming interests: increased aesthetics, reduced wind, provision of shade, privacy, wildlife habitat, economic value through increased harvest and keeping farms “out of sight and out of mind” (BCMA, 2003, p.31).

Overall, study results suggested that while both non-farm and agricultural "sides” of vegetative buffers viewed them positively, buffers alone cannot be relied upon to eliminate all farm and urban related impacts. Vegetative buffers do provide however, an important tool for reducing conflict at the urban/rural interface. Based on the challenges and benefits revealed 
during the physical assessment and interview processes, the BCMA made the following recommendations regarding development of new vegetative agricultural buffer guidelines:

- Buffers should be visually appealing to increase their acceptability and perceived effectiveness;

- Buffers composed of single or multiple rows of entirely or primarily evergreen plants are preferred over similar buffers composed of entirely or primarily deciduous plants.

- Trees in buffers should be separated from fields, yards, or other structures by a significant amount of space (i.e. 16 feet).

- Buffers should be as solid and consistent as possible (i.e. no gaps between or along the length of the buffer.)

- Based on an analysis of the effectiveness of buffers in reducing impacts, buffers approximately 30 to 40 feet high and 40 feet wide at maturity may be best.

- Buffers should have a diversity of plants and include a shrub layer as well as a tree layer.

- The list of species provided for vegetated buffers should be as large as possible to facilitate choice based on availability, function, and personal preference.

In addition to the policy papers and studies completed and published by regional and municipal entities in Australia and Canada, similar information was reviewed based on research conducted specific to California by the Great Valley Center located in Modesto. From 1998 to 2001, Sonya Hammond submitted questionnaires and conducted follow up interviews with the seventy jurisdictions in California which require agricultural buffers. Additionally, interviews were conducted with various California County Farm Bureaus and County Agricultural Commissioners. Research was targeted at determining the rationale, design and planning process associated with agricultural buffers in cities and counties throughout California. Based upon this research, in 2002 Hammond published Can City and Farm Co-exist? The Agricultural Buffer Experience in California which served to provide guidance for municipalities seeking to improve upon existing or establish new agricultural buffer policies. The document focuses on recent municipal experiences with buffers in the Central Valley region regarding buffer development and design.

Hammond identifies five main agricultural buffer types used throughout California and identifies the major advantages and disadvantages of each based upon interview responses: 
1.) Installed Barriers - this type of buffer consists of walls, fences or commercial uses which can block noise and unwanted access. Fences which are tight fitting to the ground were found to reduce the movement of certain rodents and pests. High concrete barriers or walls while generally viewed as effective, were not found to be aesthetically pleasing and can serve as targets for graffiti. Installed barriers such as warehouses/storage/industrial/commercial uses were not favored as successful if poorly landscaped or viewed as “run down.” Hammond determined that acceptability from an urban perspective tends to rely heavily upon aesthetic character and quality of landscaping/maintenance.

2.) Existing Topographic Features - this type of buffer includes features such as roads, canals, hills/valleys, roadways and utility right-of-ways, airports, parking lots and designated greenbelts. Hammond found that agricultural buffer design which incorporates the use of existing topographic or natural features can be both cost effective and help ensure that site specific topographic considerations are taken into account in the buffer design process. Incorporation of existing features into buffer design also allows for efficient use of land resources.

3.) Building Requirements or Restrictions - this buffer involves special use types, building features and setbacks. Zoning regulations are often used to create buffering effects between agriculture and residential land. Hammond found that the policy of several jurisdictions use the term setback and buffer interchangeably. Hammond further concluded that while a setback is one type of buffer, “not all setbacks are buffers” (Hammond, 2002, p.11). Hammond identified the following questions which jurisdictions should consider regarding the determination of setbacks as a component of agricultural buffer policy:

- What is a rational setback distance and who determines that distance?

- What scientific evidence supports the setback distance?

- How are provisions made for exceptions/reduction and who grants them?

- Is the setback distance process open to too much pressure or subjectivity? 
4.) Recreational or "Value-Added" Buffers - these types of buffers may include jogging trails or recreational areas and are a good option where land values are high. Hammond concluded however, that the recreational value or attraction of a value-added buffer may need to be carefully designed and managed so as to not diminish the buffer's primary purpose of conflict mitigation. In Arroyo Grande’s urban agricultural setting, recreational or “valueadded” buffers have high applicability when pedestrian access and amenities are properly screened and positioned within the buffer. With proper design, the edges of urban/agricultural parcels provide an important opportunity for connectivity in the community.

5.) Organic Farming and Modified Agricultural Uses - this buffer type involves restricting commodity practices which can be politically contentious. The financial feasibility of organic or small scale crop production is crucial to the successful implementation of this type of buffer. Hammond also emphasizes that many farmers operating on the urban edge are already subject to modified uses particularly in terms of pesticide application.

In addition to interviews, Hammond conducted review of jurisdiction agricultural buffer policy and determined that communities which were successful in implementing agricultural buffers had: 1.) a defined agricultural identity and agricultural principles, 2.) incorporation of fact and science based solutions, 3.) flexibility of buffer requirements without undue exceptions which dilute them. These criteria will be used to evaluate agricultural buffer documents and specific buffer practices in Chapter 5 .

Hammond also addressed the importance of cost to successful buffer implementation and emphasized that buffers should be promoted as another aspect of infrastructure needed to make a site suitable for housing. Such infrastructure costs are generally incorporated into the cost of the home. The use of existing infrastructure (roads, right-of-ways, canals) within buffers is also highlighted as a cost effective component of buffer design. Litter removal, painting, bank 
restoration and plant care are cited as common maintenance requirements associated with agricultural buffers. Hammond emphasizes the importance of agricultural buffers which are selfsupporting. Low maintenance buffer design, ownership and maintenance of agricultural buffers by outside entities such as Homeowner's Associations are commonly cited mechanisms through which buffers can be self-supporting.

Literature review has indicated that vegetative agricultural buffers have been scientifically proven to reduce air, soil and water pollution impacts (Dosskey 2002, Lowrance et al. 2002, Owens et al. 2007, Popov et al. 2006, Sullivan and Lovell 2006, Vought et al. 1995). Additionally, literature review has indicated that vegetative agricultural buffers have the ability to intercept and reduce pesticide spray drift (Barry, 1984, Dorr et al., 1998, Miller and Lane, 1999, Spillman and Woods, 1989, Voller, 1999, and Zande et al., 2004). Research conducted by various municipal organizations in Canada and Australia has indicated that the use of agricultural buffer policies which incorporate spatial, physical and vegetative screening components may decrease conflict experienced along the urban/agricultural edge. Buffers have also been proven to provide aesthetic benefits and have been determined to be visually preferable by rural urban interface stakeholders (Handel 1994, Nassauer, 1989, Ryan 2002, and Sullivan et al. 2004). Literature review has also determined that buffer policies vary widely among jurisdictions in California particularly in terms of setback width and vegetative screening requirements (Handel 1994).

\section{Policy Analysis Research Approach}

While the general efficacy of and stakeholder preference for vegetative buffers has been established in scientific literature and policy development research, the range for agricultural buffers in terms of setback width and vegetative screening requirements in California is still considerable. In order to make a well-founded recommendation to the City of Arroyo Grande regarding the construction of an agricultural buffer: a.) buffer implementation policies were broadly reviewed then b.) five jurisdictions were selected for further buffer criteria review and c.) 
buffer policies of the five specific jurisdictions were evaluated to determine policy effectiveness and to inform the development of Criteria for Agricultural Buffers in Arroyo Grande.

Methodology and results related to the general agricultural buffer policy survey and specific jurisdiction buffer policy analysis are detailed in Chapters 4 and 5 respectively. 


\section{Chapter 4}

\subsection{Policy Analysis of Agricultural Buffer Practices Throughout California}

A survey of the general plan and/or development code policies relating to agricultural buffers was conducted for seventeen (17) cities and eighteen (18) counties in California as displayed in Table 1.0 below.

Table 1.0 - General Policy Review Jurisdictions

\begin{tabular}{|ll|ll|}
\hline \multicolumn{1}{|l|}{ Cities } & \multicolumn{1}{l|}{ Counties } & \\
\hline City of Arroyo Grande & City of Sanger & Santa Barbara County & Sonoma County \\
City of San Luis Obispo & City of Goleta & Butte County & Sutter County \\
City of Brentwood & City of Davis & Contra Costa County & Yolo County \\
City of Salinas & City of Half Moon Bay & Monterey County & Mendocino County \\
City of Napa & City of Oakley & Sacramento County & Santa Cruz County \\
Town of Esparto & City of Ontario & Napa County & El Dorado County \\
City of El Centro & City of Fairfield & Tuolumne County & Stanislaus County \\
City of Santa Maria & & Yuba County & Kern County \\
\hline
\end{tabular}

Jurisdictions were randomly selected for evaluation based upon location within the central portion of California and the presence of agricultural land. The policy survey focused on medium sized cities with a 2000 U.S. Census of under 200,000 residents and counties which were not located within major metropolitan areas such as the Los Angeles Basin. Development code and general plan documents including Agriculture, Conservation and Open Space and Land Use elements were reviewed for reference to requirements for agricultural buffers. Details of specific buffer widths, vegetative requirements, and modification provisions were noted. Results of the document survey are available in Appendix A. 


\section{Overview of Existing Agricultural Policy in California}

Initial policy research determined that agricultural buffers for California cities generally range from 0 - 300 feet or are entirely case specific and agricultural buffers in California counties generally range from 0 - 800 feet. Certain communities have no required minimum agricultural buffer (Cities of Ventura and Santa Maria) while some jurisdictions stipulate a minimum range (Sonoma County, Cities of Brentwood and Napa). Of the thirty-five jurisdictions surveyed, seventeen referenced the use of a vegetative component within agricultural buffers and nearly all allow modification of buffer requirements for special site-specific circumstances which may require a lesser or greater buffer. The majority of jurisdictions incorporate County Agricultural Commissioner review and recommendation of agricultural buffer design. Table 1.1 below summarizes the minimum buffer widths and vegetative component requirements for the thirtyfive jurisdictions analyzed. 
Table 1.1 Summary of Jurisdiction Buffer Widths and Vegetative Component Requirements

\begin{tabular}{|c|c|c|}
\hline Jurisdiction & $\begin{array}{l}\text { Minimum Buffer Width or } \\
\text { Average Range }\end{array}$ & $\begin{array}{c}\text { Vegetative Component } \\
\text { Required or Recommended? } \\
(\mathrm{Y} / \mathrm{N})\end{array}$ \\
\hline City of Arroyo Grande & 100 feet minimum & Y (required) \\
\hline City of San Luis Obispo & Not specified & Y (recommended) \\
\hline City of Paso Robles & Not specified & $\mathrm{N}$ \\
\hline City of Brentwood & $100-300$ feet & Y (recommended) \\
\hline City of Salinas & Not specified & $\mathrm{N}$ \\
\hline City of Santa Maria & Not specified & $\mathrm{N}$ \\
\hline City of Napa & $80-120$ feet & Y(required) \\
\hline Town of Esparto & 100 feet & $\mathrm{N}$ \\
\hline City of El Centro & Not specified & $\mathrm{N}$ \\
\hline City of Sanger & Not specified & $\mathrm{N}$ \\
\hline City of Goleta & Not specified & Y (recommended) \\
\hline City of Davis & 150 feet & Y (required) \\
\hline City of Ventura & Not specified & $\begin{array}{l}\text { Y (if recommended by Ag } \\
\text { Commissioner) }\end{array}$ \\
\hline City of Half Moon Bay & Not specified & $\mathrm{N}$ \\
\hline City of Ontario & 100 feet & $\mathrm{N}$ \\
\hline City of Oakley & Not specified & $\mathrm{N}$ \\
\hline City of Fairfield & 300 feet (same as Solano County) & $\mathrm{N}$ \\
\hline Santa Barbara County & Not specified & Y (required) \\
\hline Sonoma County & $100-200$ feet & Y (recommended) \\
\hline Butte County & 300 feet & $\mathrm{N}$ \\
\hline Sutter County & $100-300$ feet & Y (recommended) \\
\hline Kern County & Not specified & $\mathrm{N}$ \\
\hline Contra Costa County & $100-500$ feet (Contra Costa Co.) & $\mathrm{N}$ \\
\hline Yolo County & $150-300$ feet & $\mathrm{N}$ \\
\hline Ventura County & $150-300$ feet & Y (required for 150 foot buffer) \\
\hline $\begin{array}{l}\text { San Luis Obispo } \\
\text { County }\end{array}$ & $100-800$ feet & Y (recommended as mitigation) \\
\hline Monterey County & 200 feet & Y (required for reduced setback) \\
\hline Mendocino County & 200 feet & $\mathrm{N}$ \\
\hline Sacramento County & $300-500$ feet & $\mathrm{N}$ \\
\hline Santa Cruz County & 200 feet & Y (required) \\
\hline Napa County & $80-120$ feet & Y (recommended) \\
\hline El Dorado County & 200 feet & $\mathrm{N}$ \\
\hline Tuolumne County & 200 feet & $\mathrm{N}$ \\
\hline Stanislaus County & $150-300$ feet & Y (required) \\
\hline Yuba County & 300 feet & Y (required for reduced setback) \\
\hline
\end{tabular}




\section{Areas in Need of Further Analysis}

Very few jurisdictions surveyed, particularly incorporated cities, offered specific guidelines or criteria for the composition of an agricultural buffer in terms of planting recommendations or density. In order to develop an informed recommendation for the City of Arroyo Grande regarding the construction of an agricultural buffer, a more in-depth analysis of specific jurisdiction buffer practices was conducted. Five (5) jurisdictions were selected for further agricultural buffer practice review based upon their applicability to the City of Arroyo Grande in terms of climate, topography or type of agricultural production. 


\section{Chapter 5}

\subsection{Policy Analysis of Specific Jurisdiction Buffer Practices}

\section{Identifying Relevant Jurisdictions}

Relevant jurisdictions were determined to be those that would reduce variation in agricultural buffer characteristics associated with climate, topography and type of agricultural production by being located in the central and coastal portion of California. Relevant jurisdictions were also selected based upon the presence of specific vegetative agricultural buffer implementation policies within the general plan and development code. Of the eighteen jurisdictions identified in the general policy survey as having a landscape or vegetative component of agricultural buffer requirements, three counties and two cities were selected for further policy review.

- The city of Davis, CA was selected based upon its location within central California, strong agricultural buffer policies, and types of crop production.

- The city of Napa, CA was also selected based upon its central location, coastal climate influence, similar topography and types of agricultural production. Both of these cities require fairly detailed agricultural buffer policy and offer political climates that tend to favor slower growth and protection of agricultural land.

- San Luis Obispo County was selected based upon its status as a neighboring jurisdiction to the City of Arroyo Grande as well as obvious similarities in climate, topography and crop production.

- Ventura County was also selected for similarity in climate, topography and crop production as well as for a political climate and history of land use policy which has favored agricultural land conservation. 
- Stanislaus County was selected primarily for its location in central California, detailed buffer policy and types of crop production.

\section{Identifying Effective Agricultural Buffer Policies}

To identify effective agricultural buffer practices, criteria developed by Sonya Hammond for the Great Valley Center and utilized in the 2002 policy paper, Can City and Farm Co-exist? The Agricultural Buffer Experience in California, were used to evaluate agricultural buffer implementation policy for the five aforementioned jurisdictions. Hammond found that effective agricultural buffer policy implementation required the following: 1.) a defined agricultural identity and agricultural principles, 2.) incorporation of fact and science based solutions, 3.) flexibility of buffer requirements without undue exceptions which dilute them. Evaluation criteria are further explained below:

\section{1.) A Defined Agricultural Identity and Agricultural Principles}

Jurisdictions with a defined agricultural identity realize the importance of agricultural land and productivity to the environmental, social and economic well-being of the community. This importance should be well - articulated within general plan goals and policies and supported within zoning ordinances or the development code. In order to evaluate a jurisdictions' agricultural identity and principles the following information will gathered during document analysis of agricultural buffer implementation policy:

- Presence of a general plan element which specifically addresses agriculture.

- $\quad$ Presence of general plan goals, policies and programs which address agriculture.

- Presence of zoning or development regulations which serve to protect agriculture.

\section{2.) Incorporation of Fact or Science-Based Solutions}

Jurisdictions which offer specific agricultural buffer requirements should preface those requirements with a factual or scientific basis to prevent arbitrary regulations. In order to 
evaluate a community's adherence to the incorporation of fact or science-based solutions into agricultural buffer implementation policy the following information will be noted during document analysis:

- Citation of or reference to any scientific studies which were used in the formation of agricultural buffer policy.

- Citation of or reference to any studies which were conducted regarding local agriculture.

\section{3.) Flexibility of Buffer Requirements}

Agricultural buffer requirements should incorporate flexibility which allows site-specific circumstances to be evaluated and addressed during the buffer design process.

Requirements should not, however, contain overly ambiguous language or provisions for exception which dilute their effectiveness or enforceability. In order to evaluate a jurisdictions' buffer policy flexibility the following information will be gathered during document analysis:

- Presence of exception or modification provisions in the buffer policy.

- Process by which exceptions or modifications may be made to buffer requirements.

\section{City of Davis, CA}

The City of Davis, CA is located eleven miles west of Sacramento on the Putah Creek Plain. Topography is generally flat with elevation ranging from 25 to 60 feet above sea level. Davis is characterized by a temperate Mediterranean climate featuring hot, dry summers and cool wet winters with average annual rainfall of 17.3 inches and a mean temperature of 62 degrees Fahrenheit (City of Davis, 2005). There is adequate rainfall for crop growth during seven months of the year; irrigation is required for continued growth during the rest of the year. Approximately 275 days of the year have a minimum temperature of 32 degrees, which constitutes the growing season. The City features a well-educated population of 65,814 residents (California Department 
of Finance, 2008) which is augmented considerably by the presence of the University of California, Davis campus. The area is characterized by extremely productive agricultural land which supports production of numerous tree, fruit and field crops including almonds, tomatoes, rice, wine and table grapes (Yolo County, 2007). Similar to the City of Arroyo Grande, Davis has some agricultural lands within the City limits. Agriculture is the most significant industry in the region. Figure 1.5 below illustrates typical agricultural landscapes near the City and in unincorporated Yolo County.

Figure 1.5 - Agricultural Landscapes near Davis, CA

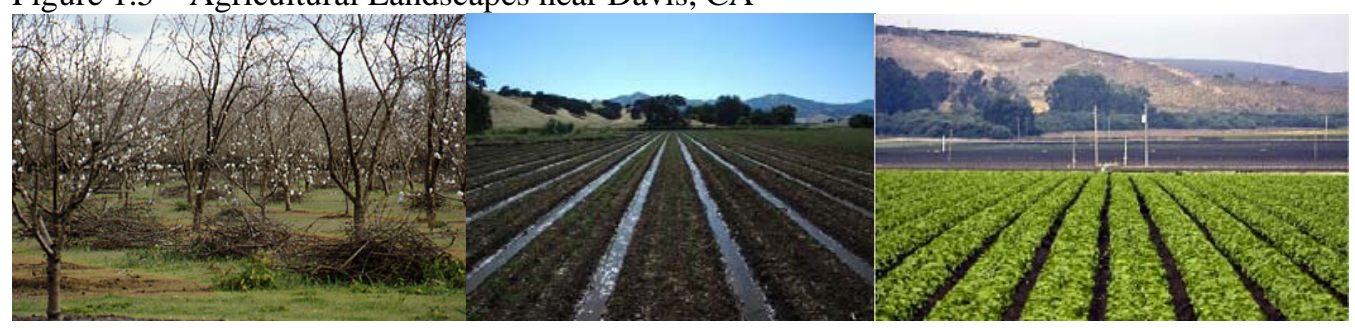

Source: UC Davis and Yolo County Department of Agriculture

The City of Davis was incorporated in 1917 and currently operates under a CouncilManager form of government with planning and development services provided through the Community Development Department (City of Davis, 2005). The City’s General Plan contains goals, policies, standards and actions for 22 different topics. The Community Resource Conservation section (VI) contains a chapter which specifically provides policy for the conservation of agriculture, soil and minerals (City of Davis, 2007a). Section VI, Chapter 15 of the Davis General Plan was last amended in January 2007. In addition to the goals, policies, standards and actions present in the Agriculture, Soil and Minerals Chapter of the General Plan, the City of Davis also has an entire chapter of the Municipal Code dedicated to Right to Farm and Farmland Preservation policy. Within this section of the Municipal Code the City has specific policies which stipulate agricultural buffer requirements. Table 1.2 below contains a summary of goals, policies, standards and actions related to the conservation of agricultural resources and the protection of agricultural land from urban development. Table 1.3 below contains a summary of 
agricultural buffer requirements contained within the municipal code including: buffer

composition, allowable uses within the buffer area and requirements for improvements,

dedication and maintenance.

Table 1.2 - Buffer Policy in the City of Davis General Plan

\begin{tabular}{|c|c|c|c|}
\hline Goal & Policies & Standards & Actions \\
\hline \multirow{7}{*}{$\begin{array}{l}\text { AG-1: } \\
\text { Maintain } \\
\text { agriculture } \\
\text { as an } \\
\text { important } \\
\text { industry } \\
\text { around } \\
\text { Davis. }\end{array}$} & \multirow{7}{*}{$\begin{array}{l}\text { AG 1.1 - } \\
\text { Protect } \\
\text { agricultural land } \\
\text { from urban } \\
\text { development } \\
\text { except } \\
\text { where the } \\
\text { general plan } \\
\text { land use map } \\
\text { designates the } \\
\text { land for urban } \\
\text { use. }\end{array}$} & \multirow{7}{*}{$\begin{array}{l}\text { New residential } \\
\text { subdivisions and other } \\
\text { urban development are } \\
\text { discouraged in areas of } \\
\text { Class } 1 \text { and } 2 \text { soils except } \\
\text { where the general plan land } \\
\text { use map has designated the } \\
\text { area for urban uses. }\end{array}$} & $\begin{array}{l}\text { Encourage participation in the Williamson Act and } \\
\text { other farmland preservation programs. }\end{array}$ \\
\hline & & & $\begin{array}{l}\text { Establish a } 150 \text { foot minimum agricultural } \\
\text { buffer around the City. Require dedication from } \\
\text { developers of lands to make up the buffer } \\
\text { concurrently with any peripheral development. }\end{array}$ \\
\hline & & & $\begin{array}{l}\text { Continue to work with counties, other cities and the } \\
\text { general public to minimize conflicts with land uses } \\
\text { such as agriculture and wildlife habitat when } \\
\text { developing agricultural buffers. }\end{array}$ \\
\hline & & & $\begin{array}{l}\text { Implement the provisions of AB } 1190 \text { to provide } \\
\text { that certain existing agricultural activities, } \\
\text { operations or facilities do not constitute a nuisance } \\
\text { as long as they continue to operate in a similar } \\
\text { manner to that in which they have historically } \\
\text { operated. }\end{array}$ \\
\hline & & & $\begin{array}{l}\text { Define land development guidelines for new } \\
\text { projects proposed adjacent to existing agricultural } \\
\text { activities. Such guidelines may include but are not } \\
\text { limited to: specific mitigation such as sound walls, } \\
\text { landscaping, berms and other constructions } \\
\text { standards. }\end{array}$ \\
\hline & & & $\begin{array}{l}\text { Continue to require disclosure agreements for new } \\
\text { developments within } 1,000 \text { feet of agricultural land. }\end{array}$ \\
\hline & & & $\begin{array}{l}\text { Continue to implement provisions of the Farmland } \\
\text { Preservation Ordinance requiring buffering, } \\
\text { notification and conflict resolution in the Planning } \\
\text { Area. Maintain a strong Right to Farm Policy. }\end{array}$ \\
\hline
\end{tabular}


Table 1.3 - Buffer Policy in the City of Davis Municipal Code

\begin{tabular}{|c|c|}
\hline \multicolumn{2}{|l|}{ Requirement For Agricultural Bu } \\
\hline \multicolumn{2}{|c|}{$\begin{array}{l}\text { - The City has determined that the use of property for agricultural operations is a high priority. } \\
\text { - To minimize future potential conflicts between agricultural and non-agricultural land uses and to protect the } \\
\text { public health, all new developments adjacent to designated agricultural preserve/agricultural open } \\
\text { space/greenbelt lands shall be required to provide an agricultural buffer/agricultural transition area. } \\
\text { - } \quad \text { Public access to a portion of the agricultural buffer will permit public views of farmland. } \\
\text { The agricultural buffer/agricultural transition area shall be a minimum } 150 \text { feet measured from the edge of } \\
\text { the agricultural/greenbelt/habitat area. } \\
\text { To achieve a maximum separation and to comply with the } 500 \mathrm{ft} \text { aerial spray setback established by Yolo and } \\
\text { Solano Counties, a buffer wider than } 150 \mathrm{ft} \text { is encouraged. }\end{array}$} \\
\hline \multicolumn{2}{|l|}{ Buffer Composition } \\
\hline \multicolumn{2}{|c|}{$\begin{array}{l}\text { The minimum } 150 \text { foot agricultural transition area/buffer shall be comprised of } 2 \text { components: } \\
\text { - A } 50 \text { foot wide agricultural transition area located contiguous to; } \\
\text { - } \quad \text { A } 100 \text { foot wide agricultural buffer located contiguous to the agricultural/greenbelt/habitat area. }\end{array}$} \\
\hline \multicolumn{2}{|c|}{ Uses Allowed in the 50 foot Agricultural Transition Area: } \\
\hline $\begin{array}{ll}\text { - } & \text { Bike paths } \\
\text { - } & \text { Community Gardens } \\
\text { - } & \text { Organic Agriculture } \\
\text { - } & \text { Native Plants } \\
\text { - } & \text { Tree and Hedge Rows }\end{array}$ & $\begin{array}{ll}\text { - } & \text { Benches } \\
\text { - } & \text { Lights } \\
\text { - } & \text { Trash Enclosures } \\
\text { - } & \text { Any other uses determined by Planning } \\
& \text { Commission to be of the same general character } \\
& \text { of aforementioned uses } \\
\end{array}$ \\
\hline \multicolumn{2}{|l|}{ Uses Allowed in the 100 foot Agri } \\
\hline $\begin{array}{ll}\text { - } & \text { Native Plants } \\
\text { - } & \text { Tree or Hedge Rows } \\
\text { - } & \text { Drainage Channels } \\
\text { - } & \text { Storm Retention Ponds }\end{array}$ & $\begin{array}{ll}\text { - } & \text { Natural Areas such as Creeks or Drainage } \\
\text { - } & \text { Swales } \\
\text { - } & \text { Railroad track and other utility corridors } \\
& \text { Commission to be consistent with the use of the } \\
& \text { property as an agricultural buffer. }\end{array}$ \\
\hline \multicolumn{2}{|l|}{ Other Requirements } \\
\hline \multicolumn{2}{|c|}{$\begin{array}{l}\text { - There shall be no public access to the } 100 \text { foot agricultural buffer unless otherwise permitted due to the } \\
\text { - } \\
\text { - Thensitive nature of the area. } \\
\text { - The buffer plan shall include provision for the establishment, management, and maintenance of the area. } \\
\text { - The plan shall incorporate adaptive management concepts and include the use of integrated pest management } \\
\text { techniques. } \\
\text { The property shall be dedicated to the City in fee title, or an easement in favor of the City shall be recorded } \\
\text { against the property which shall include the requirements of this article. } \\
\text { The City reserves its right to form a special benefit assessment district or other applicable district as is } \\
\text { permitted under state law to maintain the agricultural buffer and transition area once the land is improved, } \\
\text { dedicated and annexed. }\end{array}$} \\
\hline
\end{tabular}

\section{The City of Davis agricultural buffer policies were measured for effectiveness based}

upon the aforementioned criteria developed by Hammond. Davis was found to have both a

defined agricultural identity and agricultural principles which is established through explicit

language within the general plan and development code and the presence of a general plan

element which specifically addresses agriculture. As evidenced in Table 1.2 above, within the

general plan, there are specific goals, policies, standards and actions which serve to protect and

conserve agricultural land and production. The City of Davis further enhances general plan goals 
and policies through Chapter 40A of the Municipal Code which is dedicated solely to Farmland Preservation and Right to Farm policy as evidenced in Table 1.3 above.

City of Davis policies do not make any direct reference to scientific studies or information upon which the agricultural buffer practices are based. Buffer practices do however, offer flexibility in terms of uses permitted within the agricultural transition areas and buffers. City of Davis buffer policies stipulate a firm minimum buffer setback distance and offer few if any exceptions that may cause dilution. Buffer policy explicitly states that "To achieve a maximum separation and to comply with the 500 ft aerial spray setback established by Yolo and Solano Counties, a buffer wider than 150ft is encouraged" (City of Davis, 2007). The City of Davis agricultural buffer policy was determined to lack scientific foundation and basic flexibility, however policies were found to be firm and well-defined with permitted uses within buffers properly addressed. Specific guidance regarding construction of vegetative components within an agricultural buffer was not apparent.

City of Napa, CA

The City of Napa, CA was founded in 1847 and is located in the northern San Francisco Bay area roughly 50 miles north east of Oakland and San Francisco along the Napa River. The City has a population of 77,106 residents and an elevation of approximately 19 feet above sea level (California Department of Finance, 2008 and City of Napa, 2008). The Napa Valley region has a Mediterranean climate with roughly 24 inches of annual precipitation received between the months of October and March. Average minimum and maximum temperatures range from 37 degrees Fahrenheit in January to 82 degrees Fahrenheit in July. Napa Valley’s temperate climate and fertile soil enables a thriving agricultural industry which began with the planting of vineyards and orchards in the mid-nineteenth century and which has grown to encompass 391 wineries and annual fruit and nut crop revenues of $\$ 400,606,100$ (Napa County, 2008). According to the most recent Napa County Crop Report, the region produced 115,864 tons of wine grapes and 544 tons 
of olives in 2008. Agriculture and Tourism are the most significant industries in the region. Similar to the City of Arroyo Grande and the City of Davis, Napa contains some urban agriculture primarily small vineyards parcels. Figure 1.6 below illustrates agricultural landscapes in the Napa Valley area.

Figure 1.6 - Agricultural Landscapes near Napa, CA

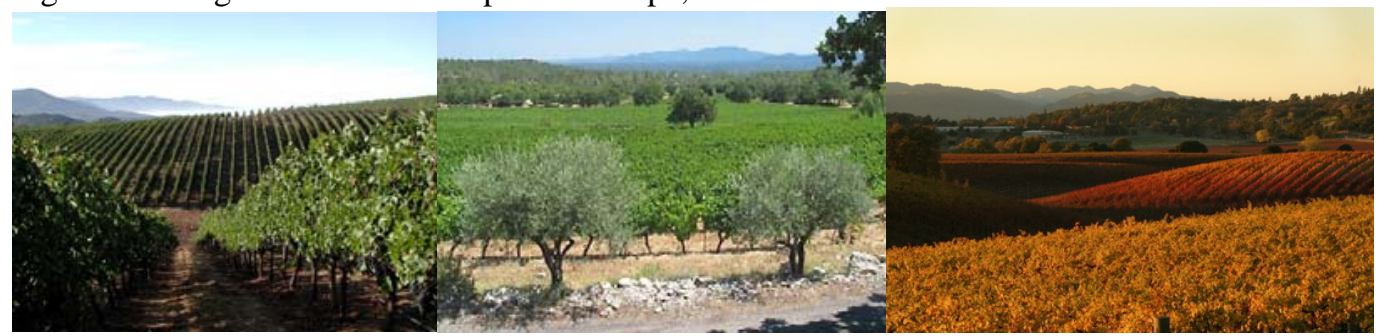

Source: Napa Valley Vintner’s Association and Napa County Farm Bureau

The City of Napa currently operates under a Council-Manager form of government with planning and development review services provided through the Planning Division of the Community Development Department. The City’s General Plan was last updated in July 2008 and contains goals, policies and programs for the following ten chapters/topics: land use, housing, transportation, community services, parks \& recreation, historical resources, natural resources, health \& safety, economics and administration. Conservation of agricultural land and the use of agricultural buffers are addressed in the Land Use chapter. A summary of goals, policies and programs related to the protection of agricultural land from urban development is located in Table 1.4 below. In addition to the goals, policies and programs present in the Land Use element of the General Plan, the City of Napa also has a section of the Municipal Code under Chapter 17.52 Site Use and Regulations which stipulated requirements for agricultural buffers. Table 1.5 below contains a summary of agricultural buffer requirements contained within section 17.52 .040 of the Municipal Code. 
Table 1.4 - Buffer Policy in the City of Napa General Plan

\begin{tabular}{|c|c|c|}
\hline Goal & Policies & Programs \\
\hline $\begin{array}{l}\text { LU - 1: To maintain and } \\
\text { enhance Napa's small-town } \\
\text { qualities and unique } \\
\text { community identity. }\end{array}$ & $\begin{array}{l}\text { LU } 1.1 \text { - The City shall maintain the Rural } \\
\text { Urban Limit (RUL) and Greenbelt designation } \\
\text { to define the extent of urban development } \\
\text { through the year } 2020 \text { and to provide for the } \\
\text { maintenance of the City's surrounding open } \\
\text { space and agriculture to separate Napa from } \\
\text { other Communities. } \\
\text { LU } 1.5 \text { - Greenways, open space, riparian } \\
\text { corridors, wetland areas, and agricultural land } \\
\text { shall be considered as important components } \\
\text { when they exist in gateway locations. }\end{array}$ & $\begin{array}{l}\text { None specifically mentioned } \\
\text { regarding agricultural land. }\end{array}$ \\
\hline $\begin{array}{l}\text { LU - 2: Maintain the Rural } \\
\text { Urban Limit (RUL) to } \\
\text { contain urban development } \\
\text { and support Napa County's } \\
\text { agriculture and other } \\
\text { resource areas. }\end{array}$ & $\begin{array}{l}\text { LU } 2.2 \text { - The City shall continue to cooperate with } \\
\text { the County to ensure that land proposed for } \\
\text { development within the RUL is annexed to the City, } \\
\text { and land outside of the RUL is conserved primarily } \\
\text { for agriculture and other resource and open space } \\
\text { uses. }\end{array}$ & $\begin{array}{l}\text { Chapter } 10 \text { - Administration } \\
\text { contains specific criteria for } \\
\text { General Plan Amendments } \\
\text { which seek to modify the } \\
\text { RUL. }\end{array}$ \\
\hline $\begin{array}{l}\text { LU - 3: Maintain an even } \\
\text { rate of development within } \\
\text { the RUL over the time } \\
\text { frame of the General Plan. }\end{array}$ & $\begin{array}{l}\text { LU } 3.2 \text { - To minimize urban/rural conflicts (e.g., } \\
\text { pesticides, odors, noise, vandalism, feral pets), the } \\
\text { City shall ensure a buffer is provided (agricultural } \\
\text { setback) between residential uses on the periphery of } \\
\text { the RUL and productive agricultural land outside the } \\
\text { RUL. }\end{array}$ & $\begin{array}{l}\text { LU - 3.D: The City shall } \\
\text { review and strengthen its } \\
\text { agricultural buffer standards } \\
\text { (landscape buffer widths, } \\
\text { plant materials within the } \\
\text { landscape buffer and } \\
\text { setback distances) to address } \\
\text { new concerns such as } \\
\text { Pierce's disease and to } \\
\text { assure it continues to meet } \\
\text { its purpose of minimizing } \\
\text { conflicts between } \\
\text { agricultural and urban } \\
\text { residential uses. }\end{array}$ \\
\hline $\begin{array}{l}\text { LU - 10: An urban pattern } \\
\text { that recognizes the } \\
\text { opportunities and constraints } \\
\text { presented by the } \\
\text { environmental setting and } \\
\text { includes accessible natural } \\
\text { amenities including hills, } \\
\text { watercourses and wetlands } \\
\text { benefitting city residents, } \\
\text { workers, and visitors. }\end{array}$ & $\begin{array}{l}\text { LU } 10.2 \text { - The City shall continue to apply special } \\
\text { development standards to proposed development } \\
\text { within or adjacent to the following areas: } \\
\text { - } \quad \text { Riparian corridors and wetlands (including } \\
\text { the Napa River); } \\
\text { - } \quad \text { Hillsides; } \\
\text { - } \quad \text { Agritical wildlife habitural and } \\
\text { LU } 10.5 \text { - When proposed development within the } \\
\text { density ranges prescribed by the underlying land use } \\
\text { designation is inconsistent with conservation of } \\
\text { critical environmental resources, the City Council } \\
\text { may reduce the project size, scale or density (to less } \\
\text { than the minimum density) provided the Council } \\
\text { makes one or more of the following findings: } \\
\text { The site is adjacent to or close to (within } 1 / 4 \text { mile) of } \\
\text { important agricultural resources or other areas } \\
\text { devoted to permanent agricultural activities which in } \\
\text { the Council's judgment are significant and would be } \\
\text { adversely affected by a project developed at the } \\
\text { minimum densities prescribed by the General Plan. }\end{array}$ & $\begin{array}{l}\text { LU - 10.B: The City shall } \\
\text { revise the Zoning } \\
\text { Designation of AR - } \\
\text { Agricultural Residential } \\
\text { District by renaming it AR - } \\
\text { Agricultural Resource } \\
\text { District to more closely } \\
\text { reflect the RA General Plan } \\
\text { designation, and by } \\
\text { requiring a Conditional Use } \\
\text { Permit for all uses (except } \\
\text { one single family residence } \\
\text { on a parcel), with a list of } \\
\text { considerations that reflect } \\
\text { the Resource, Conservation } \\
\text { and Health \& Safety } \\
\text { purposes of the General } \\
\text { Plan. }\end{array}$ \\
\hline
\end{tabular}


Table 1.5 - Buffer Policy in the City of Napa Municipal Code

Purpose and Required Provisions of Agricultural Buffers

The purpose of these regulations is to minimize potential conflicts between agriculture and urban residential uses by providing an appropriate agricultural buffer.

The following provisions shall be required for all residentially zoned lots adjacent to the Rural Urban Limit (RUL) when development is proposed:

- $\quad$ Setback - a special agricultural setback of between 80 and 120 feet between any dwellings or other buildings designed for human habitation and the nearest residential property line adjoining the URL. The exact distance shall be based upon the overall density of the residential project as follows:

$0-6$ units per acre $=80$ foot setback

$6-10$ units per acres $=100$ foot setback

Greater than 10 units per acre $=120$ foot setback

- $\quad$ Permanent landscape buffer area at least 20 feet wide.

Buffer Composition

Within the special agricultural setback a permanent landscape buffer area at least 20 feet wide measured from the residential property line(s) adjoining the RUL and nearest agricultural property line(s) shall provide a clear boundary between urban and agricultural uses. The landscape buffer shall consist of:

- A mix of trees, shrubs, berms, fences, walls, etc. sufficient to reduce noise, dust, diffuse light and act as a physical separation between the housing and agricultural activities in a design acceptable to the Planning Commission (or Community Development Department Director in the case of single-family dwellings exempt from Planning Commission review);

Submittal Requirements:

The agricultural buffer plan shall be drawn to scale, be of sufficient clarity to indicate the nature and extent of proposed work including timing or phasing and shall include the following information:

- $\quad$ Name and address of owner

- Location and Assessor's Parcel Number.

- $\quad$ North arrow and scale, as well as the name and location of the nearest public road intersection

- $\quad$ Site plan clearly showing special agricultural buffer in relation to property line(s) adjacent to the RUL line, adjacent property line(s), public streets and other features such as creeks and rivers as well as lot(s), building envelope(s) and any proposed building(s).
- $\quad$ Name, address, professional status, license number and phone number of the person who prepared the plan.

- Plans including detailed construction plans showing how the project complies with the requirements of an agricultural buffer plan including but not limited to building materials, construction techniques, and landscaping.

- A summary discussion of site design and proposed measures to mitigate the agricultural urban residential land use conflicts including setbacks, landscaping, grading and special construction techniques.

Other Requirements:

- $\quad$ No accessory structures are permitted within the landscape buffer area (except buffer fences and walls as well as pump stations or other similar improvements)

- $\quad$ Permanence of the landscaped buffer shall be assured through appropriate easements or equally effective restrictions and ongoing maintenance and funding mechanisms.

- $\quad$ Final landscape plans shall specify that all plant materials be certified by the Napa County Agricultural Commissioner inspection program for freedom from pests.

Waivers and Modifications

- $\quad$ The Planning Commission or Community Development Director may, after consultation with the Agricultural Commissioner, waive the requirement for an agricultural buffer plan for projects where it can be clearly demonstrated that no agricultural - urban land use conflicts will result from development of the property.

- The Planning Commission or Community Development Director may, after consultation with the Agricultural Commissioner, modify or substitute different requirements than those identified above for developments on a project specific basis if the different requirements will achieve the intended purpose of this section. 
The City of Napa's agricultural buffer policies were measured for effectiveness based upon the aforementioned criteria developed by Hammond. Napa was found to have a relatively well-defined agricultural identity and agricultural principles mainly established through explicit language within the general plan and development code. The City of Napa however, does not have a general plan element which specifically addresses agriculture and therefore Napa's agricultural identity and principles were found to be slightly less strong than those displayed by the City of Davis. As evidenced in Table 1.4 above, within the City of Napa general plan, there are specific goals, policies and programs which serve to protect and conserve agricultural land and production. The City of Napa further enhances its general plan goals and policies through Chapter 17.52 .040 of the Municipal Code which is dedicated to agricultural buffer policy as evidenced in Table 1.5 above.

Similar to the City of Davis, City of Napa policies do not make any direct reference to scientific studies or information upon which the agricultural buffer practices are based. Buffer practices do however, offer flexibility (minimum 80 feet - 120 feet) in terms of setback distance based upon proposed residential density of development adjoining the RUL. City of Napa buffer policies also stipulate a firm minimum permanent landscaped buffer area (20 feet) and provide clear direction as to how what the buffer area must contain and how it will reduce conflict between land uses. Specific guidance regarding construction of vegetative components within an agricultural buffer was not apparent; however, all vegetation proposed within the landscaped buffer area must be approved by the Napa County Agricultural Commissioner to prevent harboring of pests.

Buffer policies within the development code were found to provide flexibility to address site specific circumstances yet any waivers or modification of buffer requirements are subject to approval by the Planning Commission (or Community Development Director) in consultation with the County Agricultural Commissioner thereby reducing exceptions that may cause dilution. 
While buffer policy lacked explicit designation of allowable uses within buffer areas, the City of Napa buffer policies outlined in section 17.52.040 of the Municipal Code provide strong direction regarding the level of detail required for submittal of an agricultural buffer plan. Overall the City of Napa agricultural buffer policy was determined to lack scientific foundation and well-defined permitted uses within buffer areas; however, policies were found to be firm and clearly directive of the mechanisms by which conflict reduction between adjoining land uses shall be achieved through design and implementation of an agricultural buffer.

\section{County of San Luis Obispo, CA}

San Luis Obispo (SLO) County is located approximately halfway between San Francisco and Los Angeles on the Central Coast. According to the U.S. Census, SLO County encompasses roughly 3,316 square miles in area and is home to 269,337 residents (CA Department of Finance, 2008). SLO County has seven incorporated cities one of which is the City of Arroyo Grande, and fifteen area plans for unincorporated regions of the County (San Luis Obispo County, 2008). Agriculture, state institutions, tourism and recreation are the principle economic sectors in San Luis Obispo County. The City of San Luis Obispo which is the county seat is also home to California Polytechnic State University (Cal Poly), San Luis Obispo.

Fertile soil, available groundwater resources and a moderate Mediterranean climate provide for a thriving agricultural economy in SLO County. Some of the most highly productive agricultural regions of the County include irrigated croplands in the Arroyo Grande and La Cienega valleys, vineyards in Edna Valley and around Paso Robles, orchards in the Nipomo Valley as well as dry land farming in North county and cattle grazing in the coastal hills and interior valleys. San Luis Obispo County produces a variety of fruit, nut, and vegetable crops. According to the most recent Crop Report, revenue from fruit and nut production including crops such as avocados, wine grapes, lemons, strawberries and oranges totaled approximately $\$ 229,835,000$ in 2008 (San Luis Obispo County, 2008). SLO County also produces a variety of 
vegetable crops including bell peppers, broccoli, cabbage, cauliflower, lettuce, and celery. In 2008 SLO County vegetable crop revenues totaled approximately \$203,427,000. Figure 1.7 below illustrates agricultural landscapes in San Luis Obispo County.

Figure 1.7 - Agricultural Landscapes in San Luis Obispo County CA

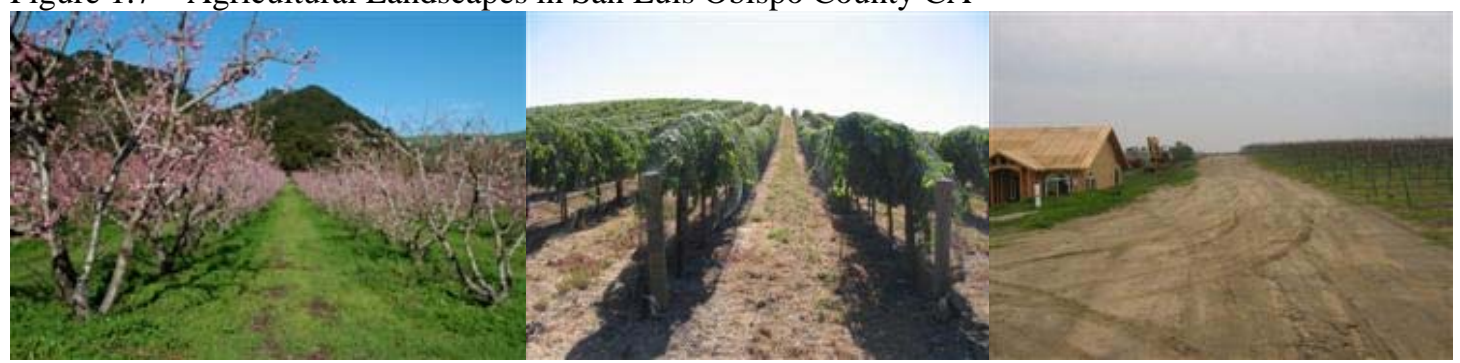

Source: San Luis Obispo County Agricultural Commissioner

San Luis Obispo County operates under a Board of Supervisors with additional land use decision-making authority and advisory input from the Planning Commission. Development Review services are provided through the Department of Planning and Building. The County Department of Agriculture's Agricultural Resources Land Use Program provides land use project review and input to ensure protection of County agricultural resources. The Agriculture and Open Space Element of the General Plan is currently going through the update process. Through this process the combined element will be divided into a separate Agriculture Element as well as a Conservation and Open Space Element. Draft elements and environmental review documents have been released and public hearings are scheduled to begin in June 2009. For the purposes of this case study the last amended Agriculture and Open Space Element (January 2007) was reviewed.

The SLO County Agriculture and Open Space Element contains four main goals including to: 1.) Support County Agricultural Production, 2.) Conserve Agricultural Resources, 3.) Protect Agricultural Lands and 4.) Encourage Public Education and Participation. SLO County has numerous policies within the Agriculture and Open Space element pertaining to the use of agricultural land, resource conservation and management and protection of agricultural land. Agriculture Policy AGP 17 specifically relates to Agricultural Buffers and states that the 
County will, Protect land designated Agriculture and other lands in production agriculture by using natural or man-made buffers where adjacent to non-agricultural land uses in accordance with the agricultural buffer policies adopted by the Board of Supervisors (Appendix D). This policy is further substantiated by two implementation measures which are summarized in Table 1.6 below.

Table 1.6 - Buffer Policy in the San Luis Obispo County General Plan

\begin{tabular}{|c|c|c|}
\hline Goal & Policy & Implementation Measures \\
\hline $\begin{array}{l}\text { AG2 - Conserve Agricultural } \\
\text { Resources } \\
\text { AG3 - Protect Agricultural Lands }\end{array}$ & $\begin{array}{l}\text { AGP } 17 \text { - Agricultural Buffers } \\
\text { Protect land designated Agriculture } \\
\text { and other lands in production } \\
\text { agriculture by using natural or } \\
\text { man-made buffers where adjacent to } \\
\text { non-agricultural land uses in } \\
\text { accordance with the Agricultural } \\
\text { Buffer Policies adopted by the Board } \\
\text { of Supervisors (Appendix D). }\end{array}$ & $\begin{array}{l}\text { 1.) The County Department of } \\
\text { Agriculture shall review } \\
\text { applications for land division, lot } \\
\text { line adjustments, land use } \\
\text { permits and proposed general } \\
\text { plan amendments for consistency } \\
\text { with the Agricultural Buffer } \\
\text { Policies adopted by the Board of } \\
\text { Supervisors (Appendix D). } \\
\text { 2.) The Department of Planning and } \\
\text { Building, the County Department } \\
\text { of Agriculture, and agricultural } \\
\text { interest groups should develop } \\
\text { proposed amendments to the } \\
\text { Agricultural Buffer Policies } \\
\text { establishing a disclosure process } \\
\text { (similar to that found in the Right } \\
\text { to Farm Ordinance, Title } 5 \text { of the } \\
\text { County Code) that would inform } \\
\text { potential buyers and sellers of } \\
\text { properties that, as part of the } \\
\text { County's approval of a } \\
\text { discretionary land use permit, an } \\
\text { agricultural buffer has been } \\
\text { applied to a property. }\end{array}$ \\
\hline
\end{tabular}

In addition to agricultural conservation goals and policies, the San Luis Obispo County Board of Supervisors adopted Appendix D of the Agriculture and Open Space Element in 2005 which provides specific policy for the use of agricultural buffers. According to the County Department of Agriculture, buffers are intended to provide:

“...space for typical farming practices to continue even when development occurs in or near farm operations. Buffers are intended to both protect farming operations from nuisance complaints and to protect the health and safety of the general public from the effects of farm operations including noise, dust, odor, legal pesticide use and other normal activities that are part of the art and business of farming and ranching." (San Luis Obispo County, 2005, p.1) 
All buffer recommendations made by the Agriculture Department are based upon the County’s Agricultural Buffer Policy contained within Appendix D of the Agriculture and Open Space Element of the General Plan which is summarized in Tables 1.7 and 1.8 below. Buffers are adopted through the land use review process and result in a legally required separation distance located on the property of the proposed development between residences, schools, and other land uses that may be potentially incompatible with nearby agricultural production. The type and extent of agricultural use as well as zoning, site specific non-agricultural factors and the nature of the land use proposal are the major factors considered by the Department of Agriculture in determining potential for significant land use conflict between proposed development and existing agricultural production. Realistic future agricultural uses on agriculturally zoned parcels are considered in the development of buffer recommendations and buffer distances are applied on a case-by-case basis considering all relevant site specific factors such as type of crop production and existing topography. 
Table 1.7 - Buffer Policy in SLO County General Plan Appendix D

Overall Agricultural Buffer Policy Statement and Objectives

The County's land use planning program serves to:

1.) Promote and protect agriculture

2.) Protect the public's health and safety

3.) Provide the Board of Supervisors and City Councils with technical information and assistance in dealing with land use compatibility and capability issues affecting agriculture.

These policies are carried out through:

- Review of land use proposals in or near agricultural areas; and

- $\quad$ Recommend mitigation measures where necessary.

Determination of Significant Land Use Conflict and Land Use Compatibility/Issue Areas

The determination of significant land use conflict is based upon the following factors:

1.) Type and extent of agricultural use, such as type of crop production.

Objectives of the County Department of Agriculture Land

Use Program serve to ensure that the Department will:

1.) Make a determination of "significant land use conflict” on project referrals and provide a basis for such determination.

2.) Recommend mitigation measures to be provided if a significant land use conflict determination is made.

2.) Zoning of the adjacent parcels.

3.) Site-specific non-crop factors such as topography and prevailing wind direction.

4.) Nature of the land use proposal.

The following land use compatibility and issue areas are considered to determine conflict potential and mitigation:

- $\quad$ Pesticide Use

- $\quad$ Noise

- Dust

- Trespass/Litter/Vandalism/Theft/Liability

- Rodent Control

- Agricultural Burning

- $\quad$ Bee Keeping

- $\quad$ Erosion and Development

- $\quad$ Other sources of land use conflict unique to certain situations

Referral Process for County Department of Agriculture Review of Land Use Proposals Affecting Agricultural Land

1.) The Agricultural Commissioner's office responds to referrals sent by the Environmental Coordinator's Office, Planning Department or city government. Responses are in writing and advisory only.

2.) An on-site evaluation is conducted usually with the applicant and/or agent. Nearby agricultural operators are contacted whenever possible.

3.) Existing agricultural use (within an appropriate range) is evaluated for potential significant land use conflict with the proposal. Realistic future agricultural uses on agriculturally zoned parcels may be considered.

4.) Buffer determinations and other mitigation measures are made on a case-by-case basis considering all relevant factors. County-wide standard or minimum setback distances are not used.

5.) Recommended mitigation measures are subject to review and modification by our staff as long as the margin of safety is maintained, potential nuisance issues are adequately addressed and potential land use conflict is maintained at a level below significance.

6.) Agricultural Commissioner land use reports will also identify potential land use conflicts and negative impact to agriculture in situations which may be partially or not mitigated. For example, even with buffer setbacks, agriculturalists may be further restricted in production practices or experience losses due to adjacent development.

Overview of Mitigation Measure Objectives and Scope

The use of agricultural buffers as mitigation measures is based upon the following:

- $\quad$ Building setbacks (buffers) and/or screening techniques such as walls and landscaping are useful to increase the likelihood of compatibility between development (homes, schools etc.) and agricultural property.

- $\quad$ Buffers are the most effective mitigation measure.

The scope of agricultural buffers as mitigation measures reflects the following:

- $\quad$ Building setbacks shall specify distances between agricultural property lines and future building sites.

- Uses within an agricultural buffer may include landscaping, barns, storage buildings, orchards, pastures, etc.

- $\quad$ The County does not have authority to restrict agricultural land use to accomplish the recommended buffer. The Commissioner may impose spray buffers and other pest management practice restrictions if needed. 
Table 1.8 - Buffer Distance Policy in SLO County General Plan Appendix D

\begin{tabular}{|c|c|c|}
\hline \multicolumn{3}{|l|}{ Agricultural Buffer Distance Determinations } \\
\hline $\begin{array}{l}\text { General guidelines for buffer distance determinations } \\
\text { include: } \\
\text { - Determinations are made based on all relevant } \\
\text { site and project criteria, practical knowledge of } \\
\text { agricultural practices, technical literature, } \\
\text { contact with other professionals within the } \\
\text { University, industry, government agencies and } \\
\text { training. } \\
\text { The concepts of “margin of safety” and } \\
\text { "probability” are used in determining setback } \\
\text { distances/ } \\
\text { Department land use reports will identify } \\
\text { recommended mitigation and not project } \\
\text { alternatives. } \\
\text { Buffer mitigations deal with reducing future or } \\
\text { additional impacts on agriculture. Existing } \\
\text { development may be such that a land use } \\
\text { proposal does not significantly worsen the } \\
\text { present land use conflict. }\end{array}$ & $\begin{array}{l}\text { considerably by type of crop, buffer } \\
\text { accordingly. Ranges are provided to } \\
\text { considerably by type of crop, buffer } \\
\text { accordingly. Ranges are provided to } \\
\text { specific or project specific factors: } \\
\text { Type of Crop } \\
\text { Vineyard } \\
\text { Irrigated Orchards } \\
\text { Irrigated Vegetables and Berries } \\
\text { Field Crops } \\
\text { Dry Farm Almonds } \\
\text { Rangeland/Pasture } \\
\text { Wholesale Nurseries } \\
\text { Animal Husbandry }\end{array}$ & $\begin{array}{c}400-800 \text { feet } \\
300-800 \text { feet } \\
200-500 \text { feet } \\
100-400 \text { feet } \\
100-200 \text { feet } \\
50-200 \text { feet } \\
100-500 \text { feet } \\
\text { See LUE }\end{array}$ \\
\hline \multicolumn{3}{|l|}{ Specific Situational Issues } \\
\hline \multicolumn{3}{|c|}{$\begin{array}{l}\text { The following specific situational issues are taken into account when the Department of Agriculture makes } \\
\text { determinations regarding land use conflict and mitigation measure recommendations: } \\
\text { - When buffers are recommended for proposed land use projects adjacent to production agriculture on non- } \\
\text { agriculturally zoned property, the report shall contain a statement that in the event farming on the adjacent } \\
\text { agricultural land is discontinued, the potential for significant land use conflict may cease and mitigation } \\
\text { measures may not be necessary. } \\
\text { The Department will not recommend the specific type of plant material or construction material for a wall or } \\
\text { fence, but may state objectives and evaluate an applicant's written proposal. Organic farming processes will } \\
\text { not typically influence mitigation measures. } \\
\text { - Specific types of proposed industrial land uses adjacent to agricultural land will be evaluated on a case-by- } \\
\text { case basis through the referral process. } \\
\text { Land use conflict may be significantly reduced is the agricultural use and the proposed use is owned/operated } \\
\text { by the same party (i.e. winery or road side stand added to an existing agricultural operation) } \\
\text { Pre-existing home sites existing within a buffer zone are not affected by buffer restrictions. Buffer only affect } \\
\text { location of new home sites. }\end{array}$} \\
\hline
\end{tabular}

\section{San Luis Obispo County’s agricultural buffer policies were measured for effectiveness}

based upon the aforementioned criteria developed by Hammond. SLO County was found to have

a relatively well-defined agricultural identity and agricultural principles mainly established

through explicit language within the general plan and presence of a specific element addressing

agriculture. As evidenced in Table 1.6 above, within the San Luis Obispo County general plan,

there are specific goals, policies and programs which serve to protect and conserve agricultural

land and production. SLO County further enhances its general plan goals and policies through

Appendix D of the Agriculture and Open Space Element of the general plan which is dedicated to agricultural buffer policy as evidenced in Tables 1.7 and 1.8 above. 
Similar to the Cities of Davis and Napa, SLO County policies do not make any direct reference to scientific studies or information upon which the agricultural buffer practices are based however; SLO County specifies that "determinations are made based on all relevant site and project criteria, practical knowledge of agricultural practices, technical literature, contact with other professionals within the University, industry, government agencies and training.” County buffer practices do offer flexibility (between 50 feet - 800 feet) in terms of setback distance based upon type of crop production. SLO County buffer policies do not stipulate a minimum permanent landscaped buffer area nor do they require a vegetative component. The Agriculture Department will not recommend specific types of plant material or construction materials for a wall or fence but will evaluate an applicant's written proposal. The County does provide an approved plant list which contains species determined to be appropriate for agricultural buffers. Buffer determinations and other mitigation measures are made on a case-bycase basis in consideration of all relevant crop and non-crop specific factors.

Buffer policies within the general plan were found to provide flexibility to address site specific issues due to County policy emphasizing case-by-case determination of buffer recommendations based crop and non-crop specific factors. Recommended buffer ranges by crop type were found to be much wider than buffer distances specified by the Cities of Davis and Napa. County buffer policy clearly states that buffer recommendations are advisory only which weakens the enforceability of buffer determinations. Overall San Luis Obispo agricultural buffer policy was determined to base land use conflict determination and buffer/mitigation recommendation on review of scientific and technical information; however, while policies were found to be firm and clearly directive of the mechanisms by which conflict reduction between adjoining land uses shall be determined, information regarding actual design and implementation of an agricultural buffer, independent of a stipulated crop specific setback range, was found to be limited. 


\section{County of Stanislaus, CA}

Stanislaus County is located in the heart of the Central Valley between San Joaquin and Merced counties. Stanislaus is one of the fastest growing counties in California encompassing roughly 1,494 square miles and home to approximately 525,903 residents (CA Department of Finance, 2008). The County consists of nine incorporated cities: 1.) Ceres, 2.) Hughson, 3.) Modesto, 4.) Newman, 5.) Oakdale, 6.) Patterson, 7.) Riverbank, 8.) Turlock and 9.) Waterford as well as seven unincorporated planning areas: 1.) Crows Landing, 2.) Del Rio, 3.) Denair, 4.) Knights Ferry, 5.) La Grange, 6.) Salida and 7.) Westley. The major economic base of Stanislaus County is agriculture; however, increased population growth has led to a diversifying economy and growth in economic sectors such as services and retail trade (Stanislaus County, 2007a). Agriculture is the leading industry in Stanislaus County generating an annual gross agricultural value in excess of two billion dollars (Stanislaus County, 2007b). Farm production supports the Stanislaus economy by generating the need for related industries such as food processing, retail and wholesale trade, marketing and transportation. Stanislaus County’s favorable climate and flat, fertile soils combined with available irrigation water and electricity have enabled it to become an agricultural epicenter within California producing a large variety of commodities such as milk, chicken and poultry products, almonds, cattle and calves, walnuts, silage, deciduous fruit and nut trees, tomatoes and peaches (Stanislaus County, 2007b). According to the 2007 Stanislaus County Crop Report, production total of all commodities equaled $\$ 2,413,571,000$. Figure 1.8 below illustrates agricultural landscapes in Stanislaus County. Figure 1.8 - Agricultural Landscapes in Stanislaus County CA

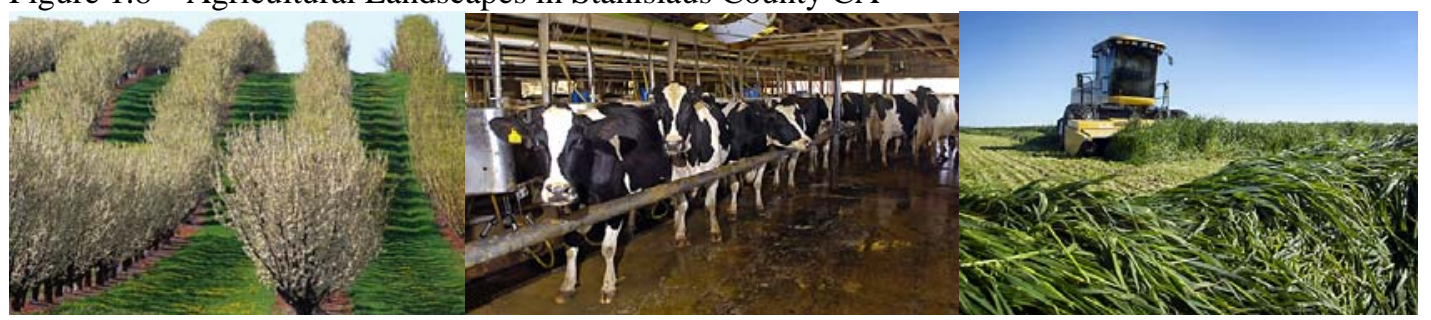

Source: Stanislaus County Farm Bureau and Agriculture Commissioner 
The same attributes that make Stanislaus County well suited for agriculture also make the County attractive for urban development (Stanislaus County, 2007a). Explosive population growth between the 1980's and 1990's and subsequent loss of agricultural resources led to the development of an Agricultural Element of the Stanislaus County General Plan in 1992 which was substantially updated in 2007. The purpose of the Agricultural Element is "to promote and protect local agriculture through the adoption of polices designed to achieve three main goals: 1.) Strengthen the agricultural sector of our economy, 2.) Conserve our agricultural land for agricultural uses, and 3.) Protect the natural resources that sustain Stanislaus County.” The Stanislaus County Agricultural Element focuses on mitigating negative economic and environmental impacts to agricultural land and establishes policies to protect agricultural production by minimizing conflicts between agriculture, the environment, and urban development. Table 1.9 below summarizes the goals, objectives, policies and implementation measures with specific emphasis on mitigating conflict between farming and non-agricultural land use.

Table 1.9 - Buffer Policy in the Stanislaus County General Plan

\begin{tabular}{|c|c|c|c|}
\hline Goal & Objective & Policy & Implementation Measures \\
\hline $\begin{array}{l}\text { 1.) Strengthen the } \\
\text { agricultural sector } \\
\text { of our economy. }\end{array}$ & $\begin{array}{l}1.7 \text { - Encourage regional } \\
\text { coordination in the Central } \\
\text { Valley }\end{array}$ & $\begin{array}{l}1.9 \text { - The County shall } \\
\text { continue to protect } \\
\text { agricultural resources by } \\
\text { limiting the circumstances } \\
\text { under which agricultural } \\
\text { operations may be deemed a } \\
\text { nuisance. } \\
1.10 \text { - The County shall } \\
\text { protect agricultural operations } \\
\text { from conflicts with non- } \\
\text { agricultural uses by requiring } \\
\text { buffers between proposed } \\
\text { non-agricultural uses and } \\
\text { adjacent agricultural } \\
\text { operations. } \\
\text { 1.22 - The County shall } \\
\text { encourage regional } \\
\text { coordination of planning and } \\
\text { development activities for the } \\
\text { entire Central Valley. }\end{array}$ & $\begin{array}{l}\text { 1-The County shall } \\
\text { continue to implement the } \\
\text { Right to Farm Ordinance; } \\
2 \text { - The County shall utilize } \\
\text { complaints related to } \\
\text { agricultural activities as } \\
\text { educational opportunities. } \\
1 \text { - The County shall require } \\
\text { buffers and setbacks for all } \\
\text { discretionary projects } \\
\text { introducing/expanding non- } \\
\text { agricultural uses in/or } \\
\text { adjacent to an agricultural } \\
\text { area consistent with the } \\
\text { guidelines presented in } \\
\text { Appendix A of the } \\
\text { Agricultural Element. } \\
1 \text { - The County shall } \\
\text { participate in regional efforts } \\
\text { to address long-range } \\
\text { planning issues. }\end{array}$ \\
\hline
\end{tabular}


Similar to San Luis Obispo County, Stanislaus County has specific agricultural buffer policies contained within an appendix to the Agricultural Element. Appendix A of the

\section{Agricultural Element of the Stanislaus County General Plan is dedicated to Agricultural Buffer}

and Setback Guidelines. Buffer guidelines and policies are summarized in Tables1.10 and 1.11.

below.

Table 1.10 - Stanislaus County Agricultural Buffer and Setback Guidelines

\begin{tabular}{|c|c|}
\hline & Buffer and Setback Gu \\
\hline & $\begin{array}{l}\text { Protect the long-term health of local agriculture by minimizing conflicts resulting from normal agricultural } \\
\text { practices as a consequence of new or expanding non-agricultural uses approved adjacent to the General } \\
\text { Agriculture zoning district. } \\
\text { Establish standards for the development and maintenance of buffers and setbacks designed to physically and } \\
\text { biologically avoid conflicts between agricultural and non-agricultural uses. }\end{array}$ \\
\hline Appl & cability \\
\hline & $\begin{array}{l}\text { guidelines shall apply to: } \\
\text { All new or expanding non-agricultural uses approved by discretionary permit in the General Agriculture } \\
\text { zoning district or on a parcel adjoining the General Agriculture zoning district. } \\
\text { Non-agricultural uses located within a LAFCO adopted SOI for an incorporated city shall be subject to these } \\
\text { guidelines if the project site is located within } 300 \text { feet of any production agriculture operation. } \\
\text { Buffer and setback requirements shall be located on the parcel for which a discretionary permit is sought and } \\
\text { shall protect the maximum amount of adjoining farmland. }\end{array}$ \\
\hline Buf & r Design Standards for New Non-Agricultural Uses \\
\hline & $\begin{array}{l}\text { All projects shall incorporate a minimum } 150 \text { foot wide buffer. Projects which propose people intensive } \\
\text { outdoor activities such as athletic fields shall incorporate a minimum } 300 \text { foot wide buffer. } \\
\text { All buffers shall incorporate a solid wall and vegetative screen consistent with the following standards: } \\
\text { Fencing: A six foot high solid wall of uniform construction shall be installed along any portion of a buffer } \\
\text { where the project site and the adjoining agricultural operation share a common parcel line. }\end{array}$ \\
\hline & $\begin{array}{l}\text { Vegetative Screen (minimum standards): } 2 \text { staggered rows of trees and shrubs characterized by } \\
\text { evergreen foliage extending from the base of the plant to the crown. Fast growing plants with a short life- } \\
\text { span shall be discouraged. Trees and shrubs should be vigorous, drought tolerant, and at least } 6 \text { feet in height } \\
\text { at the time of installation. Plants shall have } 50 \text { to } 70 \% \text { porosity. Plant height shall vary in order to capture } \\
\text { drift within } 4 \text { feet of ground application of pesticides. A mature height of } 15 \text { feet or more shall be required for } \\
\text { each tree. To ensure adequate coverage, two staggered rows of trees and shrubs shall be located } 5 \text { feet apart } \\
\text { and consist of minimum } 5 \text { gallon plants at least } 6 \text { feet tall planted } 10 \text { feet on center. Alternative spacing } \\
\text { between rows may be authorized to accommodate the needs of specific plant species. }\end{array}$ \\
\hline Per & itted Uses Within a Buffer Area: \\
\hline & $\begin{array}{l}\text { Public Roadways } \\
\text { Utilities } \\
\text { Drainage Facilities } \\
\text { Landscaping } \\
\text { Parking Lots } \\
\text { Similar low human intensity uses } \\
\text { Walking and bike areas are permitted if designed without rest areas } \\
\text { Landscaping shall be designed to exclude turf areas which may induce activities and add to overall } \\
\text { maintenance costs and water usage. }\end{array}$ \\
\hline
\end{tabular}


Table 1.11 - Additional Stanislaus County Agricultural Buffer and Setback Guidelines

Buffer and Setback Design for Expanding Non-Agricultural Uses:

- Where existing development on a project site will allow, accommodation of a buffer as required for new nonagricultural uses shall be provided.

- Where existing development on a project site will not allow a buffer as required for new non-agricultural uses, fencing and vegetative screening as required for non-agricultural uses shall be provided within the area available.

- A minimum building setback of 150 feet, measured from the property line of any adjoining property located in the General Agriculture district shall be required for any addition to an existing building or any new building associated with the expansion of a non-agricultural use.

Buffer Setback and Maintenance Criteria:

- Projects subject to these guidelines shall be conditioned to require that property owners be responsible for all aspects of on-going maintenance of buffer and setback areas.

- Property owner(s) shall be responsible for maintaining landscape plants in a healthy and attractive condition.

- A landowners association or other responsible entity shall be required to maintain buffers to control litter, fire hazards, pests, and other maintenance problems when a project consists of multiple parcels which may be held under separate ownership.

- The property owner, landowners association, or responsible entity shall be responsible for maintaining landscape plants in a healthy and attractive condition. Dead or dying plants shall be replaced with materials of equal size and similar variety within 30 days of weather permitting.

- When buffers are required as part of a specific plan, the County may require dedication of buffer areas and formation of a service district to insure long-term up keep and maintenance of the buffer. Agricultural Transition and Alternative Buffer and Setback Design Standards

- The Board of Supervisors may authorize the abandonment and reuse of buffer areas if agricultural uses on all adjacent parcels within 150 foot radius of the project site have permanently ceased.

- Any alternative buffer and setback design standards proposed by a project applicant shall be reviewed and supported by the Stanislaus County Agricultural Advisory Board prior to consideration by the Stanislaus County Planning Department. In no case shall the required standards be reduced, unless the proposed alternative is found to provide equal or greater protection to surrounding agricultural uses.

Stanislaus County’s agricultural buffer policies were measured for effectiveness based upon the aforementioned criteria developed by Hammond to determine presence of agricultural identity, scientific basis for agricultural buffer policies and policy flexibility. Stanislaus County was found to have a well-defined agricultural identity and agricultural principles mainly established through explicit language within the general plan and presence of a specific element addressing agriculture which identifies the importance of agriculture to the County's economy. As evidenced in Table 1.9 above, within the Stanislaus County general plan, there are specific goals, objectives, policies and implementation measures which serve to protect and conserve agricultural land and production. Stanislaus County further enhances its general plan goals and policies through Appendix A of the Agriculture Element of the general plan which provides specific agricultural buffer and setback guidelines as evidenced in Tables 1.10 and 1.11 above. 
Similar to the Cities of Davis, Napa and SLO County, Stanislaus County policies do not make any direct reference to scientific studies or information upon which the agricultural buffer practices are based however; County buffer and setback guidelines demonstrate consistency with several published buffer studies including the Landscaped Buffer Specifications developed by the Provincial Agricultural Lands Commission of British Columbia and the Planning Guidelines: Separating Agriculture and Residential Uses published by the Department of Natural Resources Local Government Planning in Queensland Australia. Unlike San Luis Obispo County, Stanislaus County buffer setback practices don’t offer setback distance flexibility based upon type of crop production but rather prescribe a minimum 150 foot setback for non-agricultural land uses adjacent to agriculturally zoned parcels and a minimum 300 foot setback for projects which propose people intensive uses such as athletic fields. Also unlike San Luis Obispo County, Stanislaus County buffer policy specifies a minimum buffer and requires both fencing and a vegetative component. Stanislaus County provides clear direction regarding attributes and planting density of the agricultural buffer vegetative component as summarized in Tables 1.10 and 1.11. Buffer guidelines outlined in Appendix A are considered to be minimum standards which may be intensified as needed to address project specific issues.

Buffer policies within Appendix A of the general plan were found to provide flexibility to address site specific issues yet not allow dilution of buffer effectiveness due to the requirement for alternative buffer design review and approval by the County Agricultural Advisory Board prior to consideration by the Board of Supervisors. Installation of agricultural buffers is also required for expansion of non-agricultural uses to the extent that property can accommodate buffer requirements. Appendix A also clearly stipulates buffer maintenance requirements. Overall Stanislaus County agricultural buffer policy was determined to base land recommended buffer policy on information from published buffer studies and policies were found to be firm and clearly directive regarding the construction and maintenance of an agricultural buffer. 


\section{County of Ventura, $C A$}

Ventura County is located northwest of Los Angeles County bordered by Kern County to the north, Santa Barbara County to the northwest, and the Pacific Ocean to the southwest. Ventura County formed in 1873 from Santa Barbara County and covers roughly 1,873 square miles with 43 miles of coastline. Operated as a general law county with a five member Board of Supervisors, Ventura County has ten incorporated cities, eight planning areas and approximately 831,587 residents (CA Department of Finance, 2008). Major industries within the County include: Agriculture, Biotechnology, Telecommunications, Manufacturing, Tourism and Military Testing/Development (Ventura County, 2008a).

Topography within Ventura County varies substantially from mountainous terrain in the eastern region with an elevation at Mount Piru of 8,831 feet, gradually decreasing westward through the interior valleys to the coastal plains at sea level. Ventura County’s diverse topography accounts for six different microclimates within the county’s jurisdictional boundaries. Ventura County features a Mediterranean climate ideally suited for agricultural production with an average annual temperature of 74 degrees Fahrenheit (Ventura County, 2008a). Ventura County is one of the principal agricultural counties in the state with over 80,500 acres of land zoned for agricultural production. The county grows row crops on the coastal plains, orchards on the hillsides, nursery stock in the valleys and is world renown for its high-value specialty crops such as strawberries (Ventura County, 2008a).

According to the 2007 Agricultural Commissioner’s Crop Report, Ventura County agricultural production yielded over $\$ 1.5$ billion in revenue from crops such as strawberries, nursery stock, lemons, celery and tomatoes. Figure 1.9 below illustrates agricultural landscapes in Ventura County. 
Figure 1.9 - Agricultural Landscapes in Ventura County CA

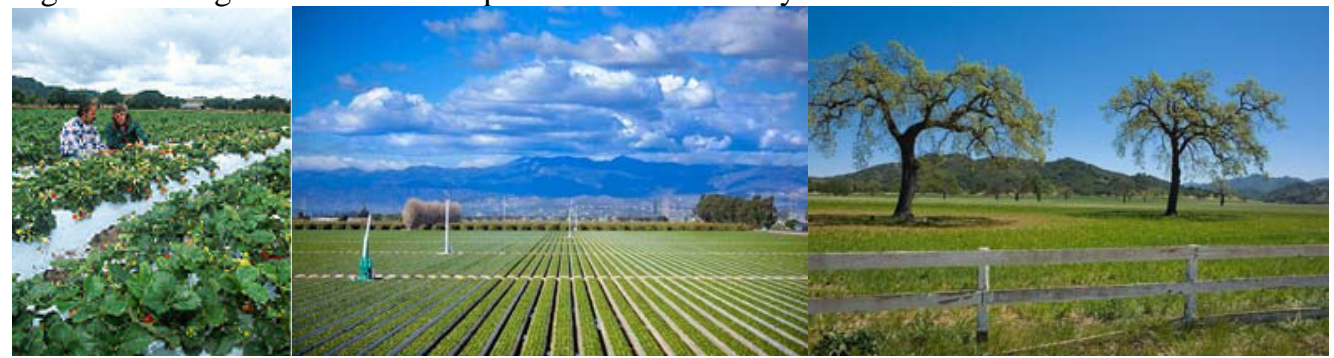

Source: Ventura County Agriculture Commissioner and Ventura County Farm Bureau

The urbanized nature of Ventura County presents many challenges to the long term viability of agricultural production (Ventura County, 2008b). The conservation of farmland resources is addressed in the Resources Element of the Ventura County General Plan, last amended in December 2008. Unlike San Luis Obispo and Stanislaus Counties, Ventura County’s general plan does not contain a separate agriculture element but rather addresses the conservation of farmland as an important county-wide resource in the Resource Element. Goals, policies and programs related to the conservation of agricultural resources in Ventura County are summarized in Table 1.12 below. 
Table 1.12 - Buffer Policy in the Ventura County General Plan

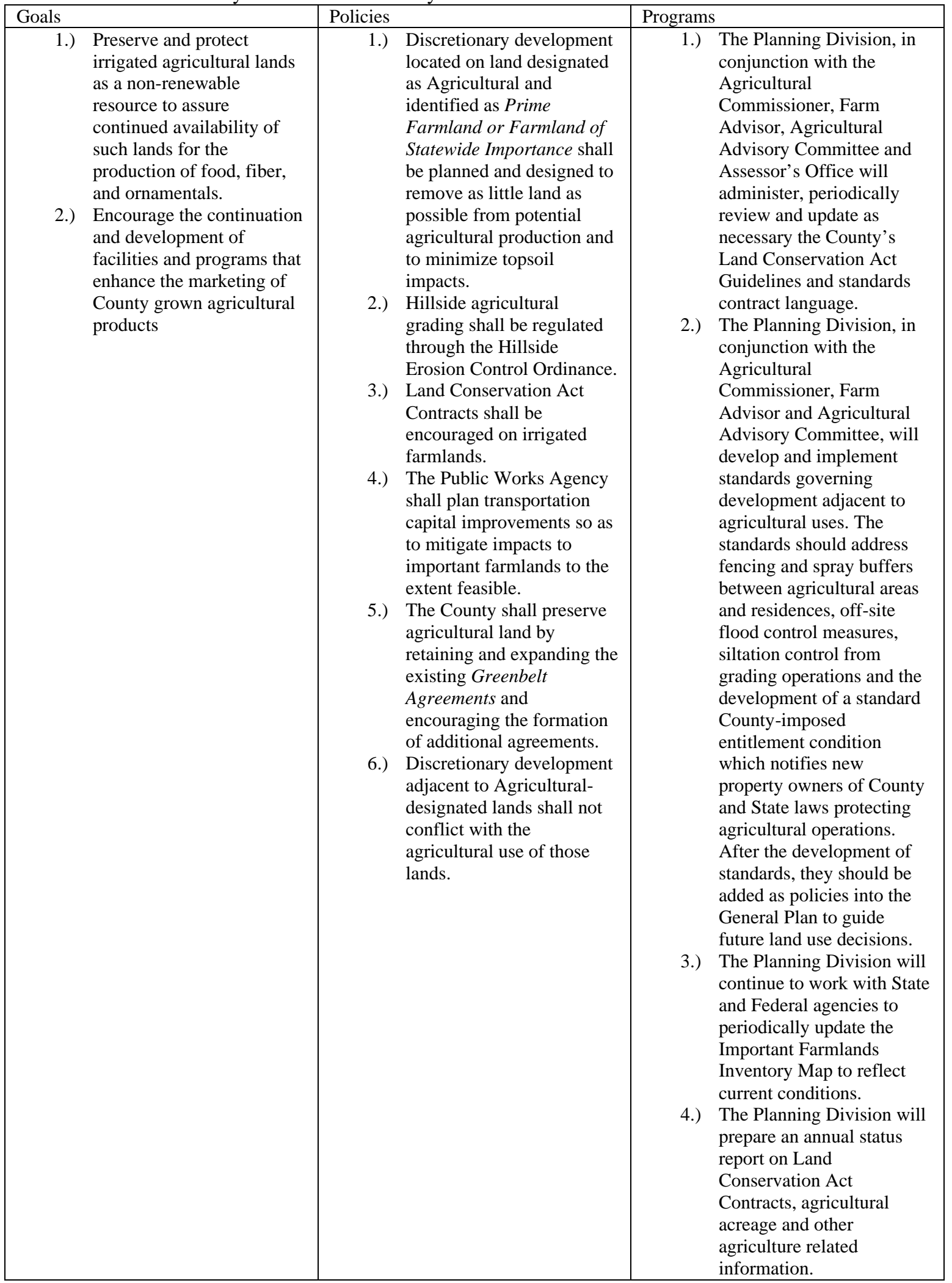


In addition to the goals, policies and programs contained within the Resources Element of the general plan, Ventura County also has several other policy mechanisms for agricultural resource protection including the Ventura County Right to Farm Ordinance as well review by the County Agricultural Commissioner's Office of all land use applications with the potential to affect agricultural resources. Land use application review at the County Agriculture Department level is two-fold: the Commissioner's Office employs a senior land use planner to review all applications and the Commissioner's Office provides staff support to the five-member Agricultural Policy Advisory Committee (APAC) which is appointed by the County Board of Supervisors to advise decision makers on individual projects, County Zoning Ordinance and General Plan amendments as well as other matters affecting the County’s agricultural resources. Another policy resource for the protection of agricultural resources in Ventura County is the “Save Open-Space and Agricultural Resources” (SOAR) Ordinance adopted in 1998 which requires county-wide voter approval of any change to the County General Plan involving the “Agricultural,” “Open-Space,” or "Rural” land use map designations, or any change to a General Plan goal or policy related to those land use designations. Ventura County's SOAR Ordinance is in effect through December 31, 2020. According to the Ag Futures Alliance (AFA), as of February 2006 every city in Ventura County with the exception of Port Hueneme is protected by either a SOAR ordinance or similar policy addressing growth (Ventura County 2008c). In addition to general plan policies, Right to Farm and SOAR ordinances, Ventura County has a third policy resource for agricultural resource protection. In September 2003, the Ventura County AFA published an issue paper, Land Use Principles to Achieve Agricultural Sustainability in Ventura County, available on the Agricultural Commissioner's website, which determined that:

Land use practices of building residential neighborhoods directly next to farmland cause continual conflicts, resulting in the steady erosion of the agricultural industry. The principles set forth in this document suggest buffers and reasonable boundaries between agricultural and urban uses to reduce conflicts and allow the best use for each segment of society, allowing both to survive and prosper. (Ventura County Ag Futures Alliance, 2003, p.3) 
The AFA set forth land use principles for agricultural sustainability in Ventura County which include the following: 1.) Buffers are necessary between agriculture and neighboring uses, 2.)

Permanent boundaries are needed between agricultural production areas and urban uses, 3.)

Development strategies should encourage protection of agricultural lands, and 4.) Regulatory

structure should allow flexibility for agricultural operations. Land use principles and policies for

long term conservation of agriculture were developed in a collaborative forum by a diverse group

of stakeholders representing agricultural, environmental and civic interests. In February 2006,

AFA published Findings and Recommendations: Follow-Up to Issue Paper No. 3 Land Use

Principles to Achieve Agricultural Sustainability in Ventura County. Table 1.13 below

summarizes the policies outlined under principle one which specifically involves the use of

agricultural buffers.

Table 1.13 - Ag Futures Alliance Buffer Principles and Recommendations

Principle 1: Buffers are necessary between agriculture and neighboring uses.

1.) Create and maintain buffers between agricultural lands and urban uses. Buffers can include both a.) physical separators such as set backs, vegetative barriers and fencing, and b) use-related separation through transitional zoning, restrictions and conditions.

2.) Buffer zones between urban and agricultural areas in all cities should be based upon consistent standards. The Ventura County Agricultural Policy Advisory Committee (APAC) and the Agricultural Commissioner should develop these consistent standards and monitor compliance by cities and the County.

3.) Responsibility for the buffer rests with the encroaching urban use, not the pre-existing agricultural use. Without buffers, urban uses can build right up to the agricultural operations or the SOAR line, jeopardizing adjoining agriculture.

4.) Where no buffer exists or is feasible, the grower should be compensated for loss of production or value due to the interfering urban use.

Recommendations:

- $\quad$ An ordinance requiring adherence with APAC guidelines must be adopted by all the cities and the county, as well as by applicable state agencies. These buffer policies need to be written into land use ordinances and General Plans in order to ensure continuity through staff and political changes within jurisdictions.

- $\quad$ Ordinances must allow for site-specific buffer solutions under special circumstances. Planners should use APAC guidelines to recommend site-specific buffer solutions that are appropriate to meet safety and functional requirements. Species of plants used, prevailing wind directions, elevations, method of application, etc. all affect the design successful buffers.

- Buffers must be the financial responsibility of the encroaching party, which generally is the urban development. They must provide land for a buffer from their encroaching project, must plant and maintain the appropriate vegetative shelter-belt and/or buy buffer rights from the adjacent farmer.

- $\quad$ LAFCO must adopt a set of rules regarding the buffer policy issue. LAFCO as the gatekeeper to new development within the county, must place appropriate conditions on any annexation of farmland in order to ensure that the adjacent farmland is able to continue sustainable farming practices. 
The proposed land use principles and recommendations outlined by the AFA are designed to be adopted by cities within Ventura County and incorporated into their planning process and documents to, "promote meaningful consensus on an applicable, long-term strategy for protection of agriculture in Ventura County.” (Ventura Ag Futures Alliance, 2003, p.3). While the land use principles are not enforceable outright, they provide an important policy resource for jurisdictions wishing to explore policy options to support agricultural sustainability and align their agricultural protection policies with those of Ventura County.

Similar to San Luis Obispo and Stanislaus Counties, Ventura County has specific agricultural/urban buffer policy however, it is not directly contained within the General Plan and is administered by the Agriculture Commissioner and the Agricultural Policy Advisory Committee (APAC). Ventura County’s Agricultural/Urban Buffer Policy was last updated in July 2006 and is summarized in Tables 1.14 and 1.15 below. 
Table 1.14 - Ventura County Agricultural/Urban Buffer Policy - Design

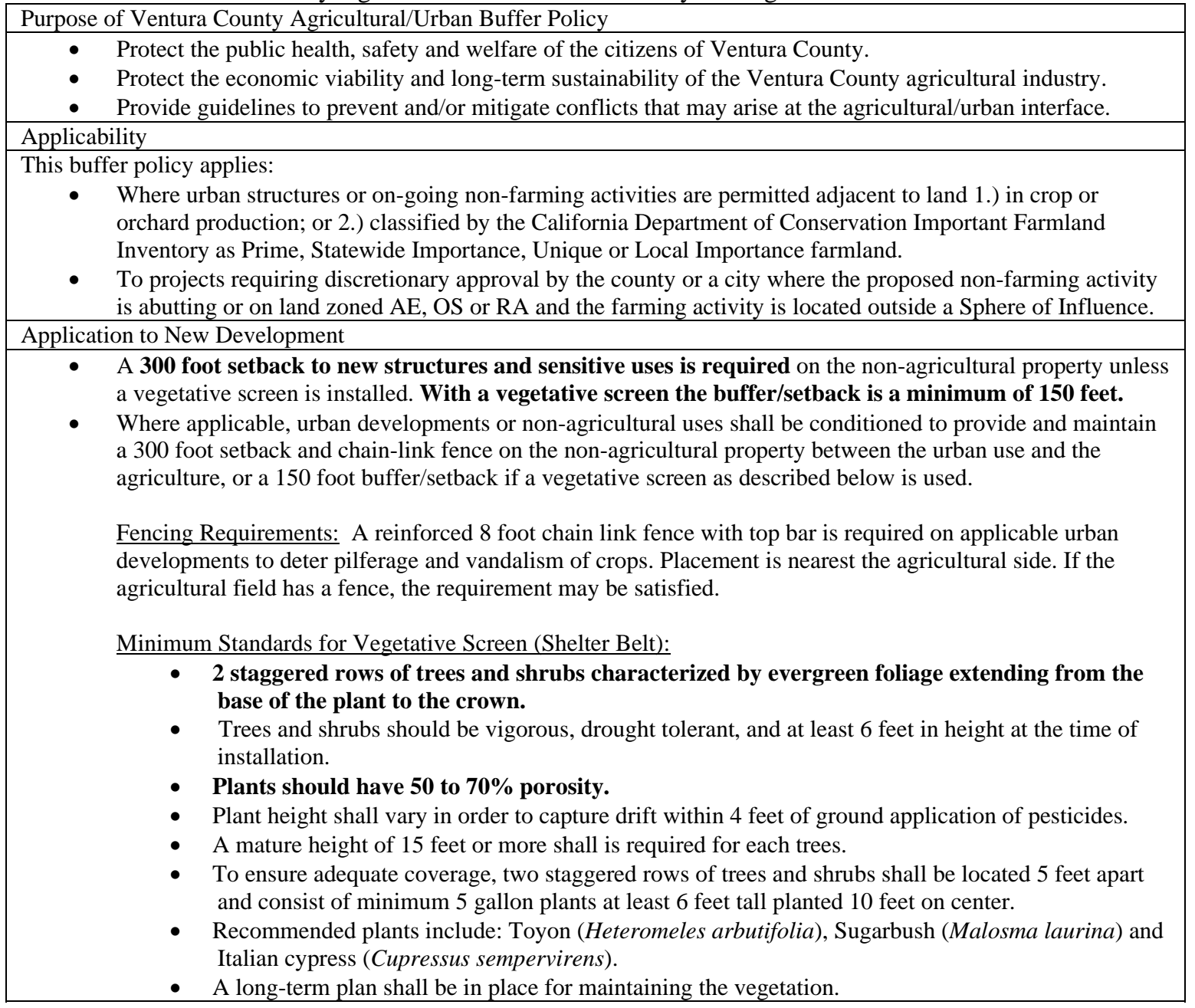


Table 1.15 - Ventura County Agricultural/Urban Buffer Policy - Use

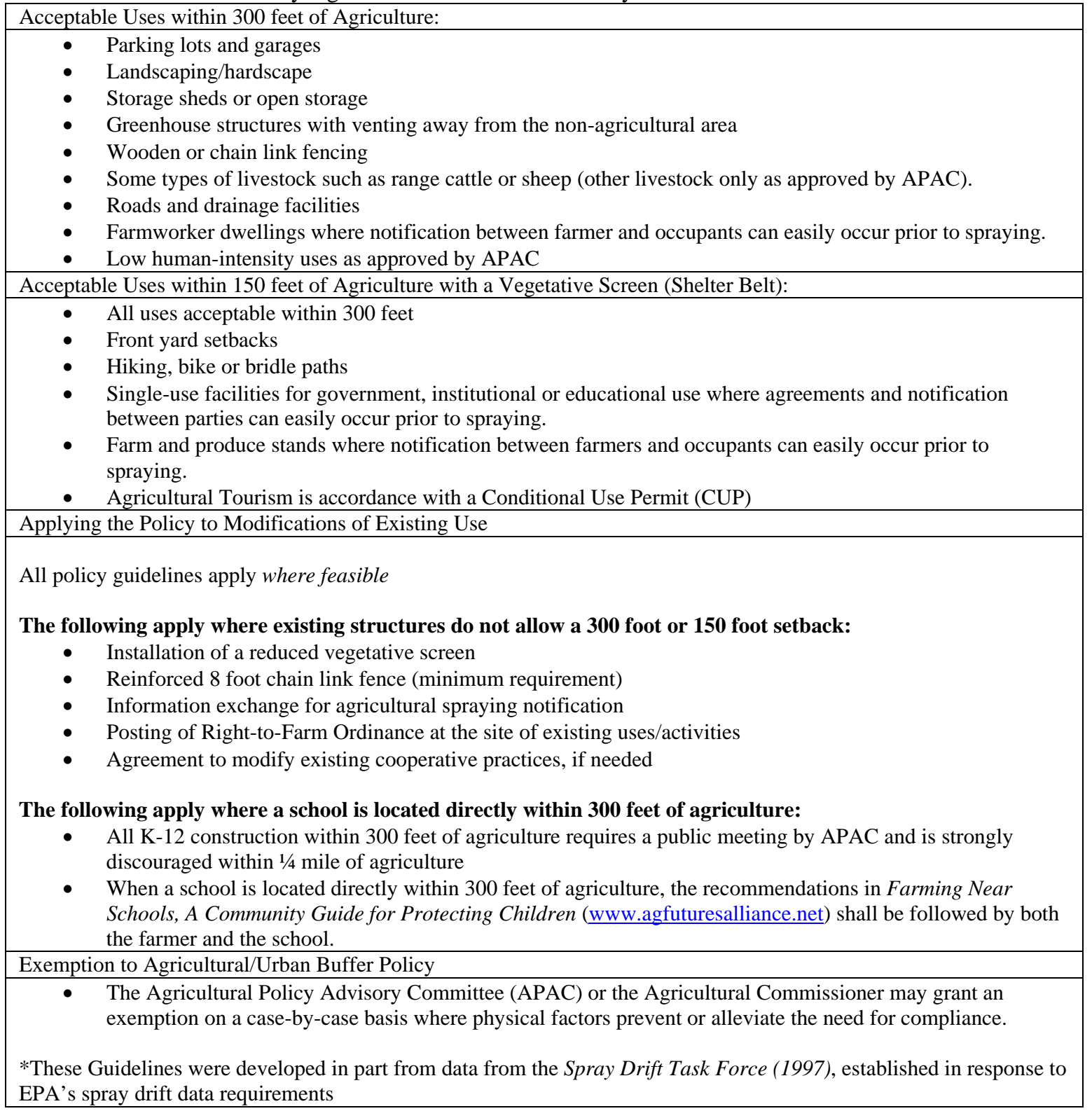

Ventura County’s agricultural buffer policies were also measured for effectiveness based upon the aforementioned criteria developed by Hammond to determine presence of agricultural identity, scientific basis for agricultural buffer policies and policy flexibility. Ventura County was found to have a moderately well-defined agricultural identity and agricultural principles mainly established through explicit language within the general plan identifying the importance of agriculture to the County's economy. As evidenced in Table 1.12 above, within the Ventura 
County general plan, there are specific goals, policies and programs which serve to protect and conserve agricultural land and production. Ventura County further enhances its general plan goals and policies through agricultural buffer policy resources published by the Ag Futures Alliance such as the Land Use Principles to Achieve Agricultural Sustainability in Ventura County summarized in Table 1.13 above and available on the County Agricultural Commissioner's website as well as specific agricultural/urban buffer policy evidenced in Tables 1.14 and 1.15 above.

Unlike the Cities of Davis, Napa, SLO County and Stanislaus County, Ventura County agricultural buffer policies do make direct reference to scientific studies and cite information upon which the agricultural buffer practices are based. Specific sources and criteria cited include studies compiled by the Spray Drift Task Force in cooperation with the US Environmental Protection Agency (EPA) Office of Pesticide Programs as well as the publications Farming Near Schools, A Community Guide for Protecting Children and Land Use Principles to Achieve Agricultural Sustainability in Ventura County both published by the Ag Futures Alliance. Similar to Stanislaus County, Ventura County agricultural/urban buffer guidelines also demonstrate consistency with additional published buffer studies including the Landscaped Buffer Specifications developed by the Provincial Agricultural Lands Commission of British Columbia and the Planning Guidelines: Separating Agriculture and Residential Uses published by the Department of Natural Resources, Local Government Planning in Queensland Australia.

Similar to Stanislaus County buffer setback practices, Ventura County agricultural/urban buffer policies also don't offer setback distance flexibility based upon type of crop production but rather prescribe a minimum 300 foot setback for non-agricultural land uses adjacent to land in agricultural production, state classified soils and agriculturally zoned parcels with a reduced setback of 150 feet with the provision of a vegetative shelter belt. Also similar to Stanislaus County, Ventura County buffer policy specifies a minimum buffer and requires both fencing and 
a vegetative component. Ventura County provides clear direction regarding attributes and planting density of the agricultural buffer vegetative component as summarized in Table X-X. Ventura County agricultural/urban buffer guidelines are considered to be minimum standards which may be reduced or intensified as needed to address project specific issues.

Ventura County buffer policies were found to provide flexibility to address site specific issues yet not allow dilution of buffer effectiveness due to the requirement that only the Agricultural Policy Advisory Committee (APAC) or the Agricultural Commissioner may grant an exemption on a case-by-case basis where physical factors prevent or alleviate the need for compliance. Installation of agricultural buffers is also required for expansion of non-agricultural uses to the extent that property can accommodate buffer requirements. Ventura County buffer policy requires that a long term plan be in place for maintaining the vegetation associated with an agricultural buffer yet does not clearly stipulate buffer maintenance requirements. Overall however, Ventura County agricultural buffer policy was determined to most closely meet the criteria outlined by Sonya Hammond regarding effective buffer policy. Ventura County buffer guidelines were found to be based upon information from published buffer studies and policies were found to be firm and clearly directive regarding the construction of an agricultural buffer. 


\section{Chapter 6}

\subsection{City of Arroyo Grande Criteria for Agricultural Buffers}

\section{Strengths and Weaknesses of Arroyo Grande Agricultural Buffer Criteria}

The City of Arroyo Grande is one of seven incorporated cities in San Luis Obispo County and is located within an ever urbanizing region which can threaten the viability of agricultural resources and production. The City of Arroyo Grande is unique in that it contains 369 acres of "urban agriculture" (land zoned agriculture within the city limits). The City of Arroyo Grande General Plan contains combined Agriculture, Conservation and Open Space elements which outline specific principals pertaining to the conservation of natural resources within the City's planning area as well as detailed objectives, policies and programs to support the specific protection and conservation of agricultural resources. Table 1.16 below outlines the principals and objectives within the Agriculture, Conservation and Open Space Element of the City of

Arroyo Grande General Plan which was last amended in March 2004.

Table 1.16 - City of Arroyo Grande Agricultural Principles and Objectives Principles and Objectives of the Agriculture, Conservation and Open Space Element

\begin{tabular}{|c|c|c|c|}
\hline \multicolumn{2}{|c|}{ Principles: } & \multicolumn{2}{|c|}{ Objectives: } \\
\hline 1.) & $\begin{array}{l}\text { Resources such as prime capability soils are } \\
\text { highly productive whether for agricultural } \\
\text { purposes, watershed, or natural habitat. }\end{array}$ & 1.) & $\begin{array}{l}\text { Avoid and/or mitigate loss of prime farmland } \\
\text { soils and conserve non-prime agricultural use } \\
\text { and natural resource lands. }\end{array}$ \\
\hline 2.) & $\begin{array}{l}\text { Resources that are irretrievable and/or } \\
\text { irreplaceable need to be protected and } \\
\text { preserved. }\end{array}$ & 2.) & $\begin{array}{l}\text { Allocate and conserve ground and surface water } \\
\text { resources for agricultural use and minimize } \\
\text { potential Fringe Area and urban development }\end{array}$ \\
\hline \multirow[t]{2}{*}{ 3.) } & $\begin{array}{l}\text { Individuals and the community have a } \\
\text { responsibility to future generations as well as to }\end{array}$ & & $\begin{array}{l}\text { that would divert such resources from } \\
\text { agriculture. }\end{array}$ \\
\hline & $\begin{array}{l}\text { wildlife to preserve and protect finite natural } \\
\text { resources. }\end{array}$ & 3.) & $\begin{array}{l}\text { Current acreage of agricultural uses within } \\
\text { Arroyo Grande's Area of Environmental }\end{array}$ \\
\hline \multirow[t]{2}{*}{ 4.) } & Resources lands contribute to overall public & & Concern shall be maintained. \\
\hline & $\begin{array}{l}\text { health, safety, and welfare beyond provision of } \\
\text { basic necessities such as foot, fiber, and } \\
\text { livelihood. }\end{array}$ & 4.) & $\begin{array}{l}\text { Support continued economic viability of } \\
\text { agriculture as a specialized site-specific } \\
\text { industry. }\end{array}$ \\
\hline \multirow[t]{2}{*}{ 5.) } & $\begin{array}{l}\text { Land use and urban development shall be } \\
\text { managed and limited to that which can be }\end{array}$ & 5.) & $\begin{array}{l}\text { Promote co-existence of agricultural and } \\
\text { urban land uses. }\end{array}$ \\
\hline & $\begin{array}{l}\text { sustained by the available resources and } \\
\text { serviced by the circulation and other } \\
\text { infrastructure systems. }\end{array}$ & 6.) & $\begin{array}{l}\text { Agriculture classification shall include } \\
\text { minimum development standards. }\end{array}$ \\
\hline
\end{tabular}


Objective Ag-5 within the general plan specifically provides policies and programs to prevent

conflict at the agricultural/urban interface. Table 1.17 below summarizes the policies and

implementation measures associated with promoting the co-existence of agricultural and urban

land uses.

Table 1.17 - City of Arroyo Grande General Plan Buffer Policy

\begin{tabular}{|c|c|c|}
\hline Objective & Policy & Program \\
\hline $\begin{array}{l}\text { AG-5 Promote Co-existence of } \\
\text { agricultural and urban land uses. }\end{array}$ & $\begin{array}{l}\text { AG-5-2 Establish criteria for buffers } \\
\text { between Agriculture land use } \\
\text { designations and non-Agriculture } \\
\text { land use designations. } \\
\text { AG-5-3 Land use conversions shall } \\
\text { not adversely affect existing or } \\
\text { potential agriculture production on } \\
\text { adjacent lands designated } \\
\text { Agriculture. } \\
\text { AG-5-4 Design special assessments } \\
\text { that are equitable with regard to } \\
\text { benefits, such that agricultural land } \\
\text { owners are not disproportionately } \\
\text { assessed for services that accrue to } \\
\text { urban residents more than farmers or } \\
\text { ranchers. Examples of such urban } \\
\text { services include fire protection, park } \\
\text { and recreation services and } \\
\text { neighborhood street lighting. } \\
\text { AG-5-5 Minimize trespassing into } \\
\text { agricultural areas, through signage, } \\
\text { access restrictions, fines and other } \\
\text { available means. } \\
\text { AG-5-6 Establish a grievance or } \\
\text { arbitration committee to mediate land } \\
\text { use disputes between farmers and } \\
\text { adjoining non-farm residents. }\end{array}$ & $\begin{array}{l}\text { AG-5-1.1 Extend Right-to-Farm } \\
\text { provisions to new areas that are } \\
\text { adjoining lands approved for addition } \\
\text { to the Agricultural district. } \\
\text { AG-5-2.1 Buffers shall be established } \\
\text { on all parcels proposed for non- } \\
\text { agricultural development adjacent to } \\
\text { agricultural uses, when the property } \\
\text { is exposed to agricultural operations. } \\
\text { AG-5-2.2 No portion of any new } \\
\text { residential structure within a non- } \\
\text { agricultural land use designation shall } \\
\text { be located closer than } 100 \text { feet from } \\
\text { the site of agricultural operations } \\
\text { within an agricultural land } \\
\text { designation. Greater distances may } \\
\text { be required based upon site-specific } \\
\text { circumstances to include } \\
\text { consideration of established or } \\
\text { existing farming operations or } \\
\text { practices. } \\
\text { AG-5-2.3 The buffer area shall be } \\
\text { noticed and/or fenced and landscaped } \\
\text { in such a manner to discourage } \\
\text { human and domestic animal } \\
\text { movement between the urban and } \\
\text { agricultural areas and to screen urban } \\
\text { uses from dust and wind-borne } \\
\text { materials. } \\
\text { AG-5-2.4 The buffer area shall } \\
\text { contain a minimum } 20 \text { feet depth of } \\
\text { landscaping. Plantings shall be } \\
\text { sufficiently dense and mature to } \\
\text { provide aerosol protection within the } \\
\text { first year of establishment. Greater } \\
\text { landscaping depth may be required } \\
\text { based upon site-specific } \\
\text { practing farming operations or } \\
\text { ponstances, to include }\end{array}$ \\
\hline
\end{tabular}


Based upon review of and comparison with other jurisdictions in California, the City of Arroyo Grande’s agricultural buffer policies were found to be relatively comprehensive, with strong directive language and minimum buffer setback requirements including fencing and screening. Additionally, the City's buffer policies offer flexibility to address site specific circumstances without overly permissive language which could dilute enforceability.

Arroyo Grande buffer policy was also found to have a few key weaknesses which may hinder implementation and successful application of buffer policies. While it is important to maintain flexibility to address site-specific circumstances, ambiguity associated with implementation measures can be confusing for project applicants, planners, and decision makers. For example, implementation measure AG-5-2.4 as noted in Table 1.17 above stipulates that "The buffer area shall contain a minimum 20 feet depth of landscaping. Plantings shall be sufficiently dense and mature to provide aerosol protection within the first year of establishment" (City of Arroyo Grande, 2001, p. AgC/OS-10). This measure adequately stipulates that the vegetative buffer shall be planted to provide aerosol protection, however, further direction is needed to provide guidance on the proper vegetative construction of a buffer for aerosol protection.

Additionally, Arroyo Grande buffer policies make no reference to or recommendation of planting materials to be used within an agricultural buffer besides the allowance of native plants, tree and hedgerows within the agricultural buffer area. San Luis Obispo County agricultural buffer policy also does not specifically address planting materials however the County does have an approved plant list which contains species approved for agricultural buffers and provides information on native species, mature height and drought tolerance as well. The San Luis Obispo County approved plant species list for agricultural buffers will be incorporated into the City of Arroyo Grande agricultural buffer criteria with specific emphasis on the utilization of drought tolerant, native species, with the ability to provide habitat for beneficial insects and low risk for 
harboring pests. The list of species will provide informal guidance for planting materials within an agricultural buffer.

In addition to lack of guidance regarding planting materials, City of Arroyo Grande buffer policies also do not provide much information regarding the construction of a buffer to provide sufficient density and height to address aerosol interception, dust and trespass. Based upon literature review and review of other jurisdictional buffer policies, some basic minimum requirements for the vegetative buffer component have been developed including:

- Planting multiple, staggered rows of trees and shrubs.

- Ensuring that vegetation provides at least $50 \%$ porosity.

- Staggered rows should consist of 5 gallon trees/shrubs at least 6 feet tall, planted 5 feet apart and 10 feet on center.

- Minimum mature tree height should be 15 feet.

- More specific language that residential yards are to be excluded from the agricultural buffer to maintain long term viability and integrity of the buffer

- More specific maintenance language including provisions to maintain porosity and replace vegetation.

- More specific maintenance language which stipulates that buffer maintenance should be included as the responsibility of the property owner or Homeowners Association in CC\&R's or included in a deed restriction.

- More specific submittal requirements for agricultural buffer plans.

\section{Draft Agricultural Buffer Criteria for the City of Arroyo Grande}

The following draft document was developed to outline adopted agricultural buffer polices in the City of Arroyo Grande General Plan and Municipal Code. A copy of the Draft Agricultural Buffer Criteria for the City of Arroyo Grande is also available in Appendix B. In addition to adopted polices, criteria for agricultural buffers are listed which provide informal 
guidance on the actual construction of an agricultural buffer in the City, Criteria define planting density and height requirements to address aerosol interception, dust and trespass as well as suggestions for plant species and fencing requirements. These criteria are based upon literature review as well as review of existing buffer policies in jurisdictions throughout California. The Agricultural Buffer Criteria for the City of Arroyo Grande are designed to be incorporated by reference into the municipal code to supplement general plan policies and municipal code language to provide informal guidance for project applicants, planners and decision makers regarding the site-specific construction of an agricultural buffer in Arroyo Grande.

\section{Purpose}

According to Section 16.12.170 E 1 of the Municipal Code, the purpose of these regulations is to minimize potential conflicts between agricultural and non-agricultural land uses including: the protection of public health, the reduction of noise and odor, and the reduction of risk to farm operations from domestic animal predation, crop theft, damage and complaints from neighboring urban dwellers.

\section{Applicability}

According to Section 16.12.170 E 1 of the Municipal Code, all new “development” adjacent to any designated agricultural district shall be required to provide an agricultural buffer.

“Development” includes: subdivision of land, issuance of use permits and building permits for new residential units. According to implementation measure AG-5-2.1 of the Arroyo Grande Agriculture Conservation and Open Space Element, buffers shall be established on all parcels proposed for non-agricultural development adjacent to agricultural uses, when the property is exposed to agricultural operations.

\section{Minimum Buffer Standards}


In accordance with the City of Arroyo Grande General Plan Agriculture Conservation and Open

Space Element as well as section 16.12.170 E of the Municipal Code, the following minimum

buffer standards are required:

- No portion of any new residential structure or use within a non-agricultural land use designation shall be located closer than 100 feet from the site of agricultural operations within an agricultural land use designation. Remodeling of existing residences is permitted. Greater distances may be required based upon site-specific circumstances, to include consideration of established or existing farming operations or practices.

- The buffer area shall be a minimum of 100 feet measured from the edge of the agricultural district. To achieve a maximum separation, a buffer wider than 100 feet is encouraged and may be required if it is determined through environmental review under CEQA and/or recommended by the San Luis Obispo County Agricultural Commissioner.

- A decreased buffer distance may be allowed if it can be demonstrated that a physical buffer exists (e.g. Arroyo Grande Creek) that is adequate and approved by the San Luis Obispo County Agricultural Commissioner. (Municipal Code Section 16.12.170 E 2)

- The minimum 100 foot $^{1}$ agricultural buffer area shall be comprised of two components: 1.) A 20 foot wide agricultural landscaped transition area $^{2}$ contiguous to;

2.) An 80 foot wide agricultural buffer located adjacent to the agricultural district.

- The buffer area shall contain a minimum 20 feet depth of landscaping. Plantings shall be sufficiently dense and mature to provide aerosol protection within the first year of establishment. Greater landscaping depth may be required based upon site-specific circumstances, to include consideration of established or existing farming operations or practices.

- The buffer area shall be noticed and/or fenced and landscaped in such manner to discourage human and domestic animal movement between the urban and agricultural areas and to screen urban uses from dust and wind borne materials.

Permitted Uses within the 100 foot Agricultural Buffer*

- Native Plants, Tree or Hedgerows

- Roads

- Drainage Channels and Storm Retention Ponds

- Natural areas such as creeks or drainage swales

- Utility corridors

- Storage

- Any use (including agricultural or limited commercial uses) determined by the Planning Commission to be consistent with the use of the property as an agricultural buffer.

- No new residential uses shall be permitted within the buffer area unless it is determined that there would be no other economically viable use of the property. Remodeling of existing residential structures is permitted.

\footnotetext{
${ }^{1}$ The combined 100 foot agricultural buffer shall not qualify as farmland mitigation as required by Section 16.12.170 F of the Municipal Code.

2 The 20 foot transition area may include pedestrian access.
} 
* Residential yards are not permitted within the agricultural landscaped transition area or within the agricultural buffer so as to maintain the viability and integrity of the buffer.

\section{Submittal and Maintenance Requirements}

- The 100 foot agricultural buffer shall be established by the developer pursuant to a plan approved by the Community Development Department Director and the Parks, Recreation, and Facilities Director.

- The plan shall include provisions for the use of integrated weed and pest management techniques and soil erosion control.

- An agreement in the form approved by the City Attorney shall be recorded which shall include the requirements of this section.

Additional Criteria for the Design and Maintenance of an Agricultural Buffer:

In addition to the Purpose, Applicability, Permitted Uses, Minimum Buffer Standards, Submittal and Maintenance Requirements outlined in the General Plan and Municipal Code, the following additional criteria for agricultural buffers are encouraged. Agricultural buffers should consist of a mix of trees, shrubs, berms, fences, walls etc. sufficient to reduce noise, dust, diffuse light and act as a physical separation between urban and agricultural activities. All buffers should incorporate a solid architectural, landscaped wall and vegetative screening component to reduce conflict potential between urban and agricultural uses. At minimum the following fencing and vegetative criteria should be used:

- Installation of a minimum 6 foot high solid fence or wall where the urban use and agricultural district share a common property line.

- Vegetative screen should consist at minimum of $1-2$ staggered rows of 5 gallon sized deciduous or coniferous trees and shrubs located 5 feet apart and planted 10 feet on center.

- Vegetative screen should have between 50 - 75\% porosity (50 - 75\% of the buffer vegetation should be airspace).

- Trees and shrubs should be vigorous, drought-tolerant and at least 6 feet in height at the time of installation.

- Fast growing plants with a short lifespan are discouraged. Species with long, thin, rough foliage are encouraged. Native plant species are preferred.

- Where the potential for conflict between agricultural and non-agricultural uses is high, additional rows of vegetation and physical screening may be appropriate. 


\section{Plant Palette}

Planting recommendations should be determined based upon site-specific circumstances with special emphasis on promoting integrated pest management, erosion, and weed control. Figure 1.10 below lists County-approved plant species that are approved for use in agricultural buffers.

Figure 1.10 - County Approved Buffer Plants

\begin{tabular}{|c|c|c|c|c|}
\hline Botanical Name & Common Name & Type & CA Native & Water Need \\
\hline Agonis flexuosa & Peppermint Tree & tr & $\mathrm{N}$ & 10 \\
\hline Arbuts 'Marina' & Marina Arbutus & tr & $\mathrm{N}$ & av \\
\hline Arbutus unedo & Strawberry Tree & tr & $\mathrm{N}$ & 10 \\
\hline Callistemon (varieties) & Bottlebrush & sh & $\mathrm{N}$ & hi \\
\hline Calocedrus decurrens & Incense Cedar & tr & $\mathrm{Y}$ & lo \\
\hline Cedrus deodora & Deodar Cedar & tr & $\mathrm{N}$ & av \\
\hline Choisya ternata & Mexican Orange & sh & $\mathrm{N}$ & to \\
\hline Cupressus glabra & Smooth Arizona Cypress & tr & $\mathrm{N}$ & 10 \\
\hline Garrya elliptica & Coast silk-tassel bush & sh/tr & $\mathrm{Y}$ & lo \\
\hline Geijera parviflora & Australian Willow, Wilga & tr & $\mathrm{N}$ & av \\
\hline Grevillea (varieties) & Grevillea & $\mathrm{tr} / \mathrm{sh}$ & $\mathrm{N}$ & 10 \\
\hline Hakea suaveolens & Sweet Hakea & sh & $\mathrm{N}$ & 10 \\
\hline Hetromeles arbutifolia & Toyon, Christmas Berry & sh/tr & $\mathrm{Y}$ & lo \\
\hline Lingustrum lucidum & Glossy Privet & tr & $\mathrm{N}$ & hi \\
\hline Melaleuca (varieties) & Melaleuca & sh/tr & $\mathrm{N}$ & 10 \\
\hline Metrosiderous excelsus & New Zealand Christmas Tree & tr & $\mathrm{N}$ & lo \\
\hline Photinia fraseri & Photinia & sh & $\mathrm{N}$ & av \\
\hline Pittosporum (varieties) ${ }^{\star \star}$ & Pittosporum & sh/tr & $\mathrm{N}$ & av \\
\hline Prunus caroliniana & Carolina Laurel Chetty & $\mathrm{sh} / \mathrm{tr}$ & $\mathrm{N}$ & lo \\
\hline Prunus ilicifolia & Holly-leaf Cherry & sh/tr & $\mathrm{Y}$ & 10 \\
\hline Prunus lyonii & Catalina Cherry & sh/tr & $\mathrm{Y}$ & 10 \\
\hline Quercus agrifola & Coast Live Oak & tr & $\mathrm{Y}$ & lo \\
\hline Quercus chrysolepsis & Canyon Live Oak & tr & $\mathrm{Y}$ & lo \\
\hline Quercus engelamnnii & Mesa Oak & tr & $\mathrm{Y}$ & lo \\
\hline Quercus wislizenii & Interior Live Oak & tr & $\mathrm{Y}$ & 10 \\
\hline Rhamnus californica & Coffeeberry & sh & $\mathrm{Y}$ & 10 \\
\hline Rhapiolepsis & Majestic Beauty & sh & $\mathrm{N}$ & 10 \\
\hline Rhus integrifolia & Lemonade Berry & sh & $\mathrm{Y}$ & 10 \\
\hline Rhus ovata & Sugar Bush & sh & $\mathrm{Y}$ & 10 \\
\hline
\end{tabular}

$\begin{array}{llll}\text { Height } & \text { Growth Rate } & \text { Climate } & \text { Other } \\ 25-35^{\prime} & \text { mod - fast } & 15-17,20-24 & \\ 40^{\prime} & \text { slow } & 8,9,14-24 & \text { oak root fungus resistant } \\ 8-35^{\prime} & \text { slow } & 4 \text { thru } 24 & \text { oak root fungus resistant, bears fruit } \\ 4-30^{\prime} & & 8,9,12-24 & \text { C. viminalis good for S } W \text { exposure } \\ 75-90^{\prime} & & 1-12,14-24 & \text { slow growth then 2' per year } \\ 80^{\prime} & \text { fast } & 2-12,14-24 & \text { good inland plant } \\ 8^{\prime} & \text { fast } & 7-9,12-17 & \\ 40^{\prime} & \text { fast } & 5,8 \text { thru } 24 & \text { wind resistant, good wildlife and inland plant } \\ 4-30^{\prime} & \text { mod - fast } & 5-9,14-21 & \text { good with oaks, near coast, wildlife, tolerate deer } \\ 25-35^{\prime} & \text { mod } & 8,913-24 & \text { resistant to oak fungus } \\ 3-60^{\prime} & \text { mod - fast } & \text { varies } & \text { good for S/W exposure } \\ & \text { fast } & 9,12-17,19-24 & \text { good for sea coasts } \\ 6-25^{\prime} & \text { slow - mod } & 5 \text { thru } 24 & \text { good with oaks, good wildlife cover } \\ 35-50^{\prime} & \text { fast } & 5,6,8-24 & \text { wind resistant, potentially invasive, messy fruit } \\ 6-30^{\prime} & \text { fast } & \text { varies } & \text { NOT M. linarifolia (highly ignitable) } \\ 30-35^{\prime} & \text { mod } & 17,23,24 & \text { (Tormentosus) } \\ 10^{\prime} & \text { mod } & 4 \text { thru } 24 & \text { caution around animals, good for } S M W \text { exposure } \\ 20-35^{\prime} & \text { slow - mod } & \text { varies } & \\ 20-40^{\prime} & \text { fast } & 7 \text { thru } 24 & \text { caution around animals, good for } S M \text { exposure } \\ 20-30^{\prime} & \text { mod } & 7-9,12-24 & \text { resistant to oak fungus, good with oaks, wildlife } \\ 25-35^{\prime} & \text { mod } & 7-9,12-24 & \text { resistant to oak fungus, caution around animals } \\ 20-70^{\prime} & \text { mod } & 7-10,12,14-24 & \text { good wildlife and inland plant } \\ 20-65^{\prime} & \text { mod } & 5-9,14-24 & \text { good wildlife and inland plant } \\ 50-60^{\prime} & \text { slow - mod } & 18-24 & \text { good wildlife and inland plant } \\ 30-75^{\prime} & \text { slow - mod } & 7-9,14-16,1-21 & \text { good wildlife and inland plant } \\ 15-20^{\prime} & & 4 \text { thru } 24 & \text { good with oaks } \\ 15^{\prime} & & 4-10,12-24 & \\ & & 15-17,20-24 & \\ & & 7 \text { thru } 24 & \text { heat tolerant } \\ & & & \end{array}$

Source: SLO County Agricultural Commissioner

\section{Additional Maintenance Guidelines}

Municipal code provisions stipulate that an agreement in the form approved by the City Attorney shall be recorded which include the requirements of Section 16.12.170 E. Additional basic maintenance guidelines should be included as project conditions including:

- Property owner(s) are responsible for all aspects of on-going maintenance of buffer and setback areas.

- Property owner(s) shall be responsible for maintaining landscape plants in a healthy and attractive condition. Dead or dying plants shall be replaced with materials of equal size and similar variety within 30 days of weather permitting.

- A Homeowners's Association or other responsible entity shall be required to maintain buffers to control litter, fire hazards, pests, and other maintenance problems when a project consists of multiple parcels which may be held under separate ownership.

- Buffer maintenance requirements shall be stipulated through inclusion in Covenants, Conditions and Restrictions (CC\&Rs) or through deed restriction. 


\section{Additional Submittal Guidelines}

In addition to the submittal requirements outlined in Section 12.16.170 E 5, the following submittal guidelines are encouraged to ensure that review and processing of project applications requiring agricultural buffers is efficient and effective. Agricultural buffer project submittals should include:

- Name and address of owner, property location and Assessor's Parcel Number.

- North arrow and scale as well as the name and location of the nearest public road intersection.

- Name, address, professional status, license number, and phone number of the person who prepared the plan.

- Site plan should clearly show the special agricultural buffer in relation to property lines adjacent to the agricultural district, adjacent property lines, public streets and other features such as creeks as well as lots, building envelopes and any proposed buildings.

- Plans should include detailed construction plans showing how the project complies with the agricultural buffer policies outlined in the Agriculture, Conservation and Open Space Element of the General Plan, Section 12.16.170 E of the Municipal Code and the additional buffer criteria in this document.

\section{Schematic Buffer Examples}

The following schematic examples illustrated in Figures 1.11, 1.12 and 1.13 were developed to demonstrate example buffer construction for development scenarios which involve minimum, moderate and maximum potential for conflict between urban and agricultural uses. Actual buffer design and construction will vary based upon site specific circumstances. 
Figure 1.11 - Example Minimum Buffer Schematic

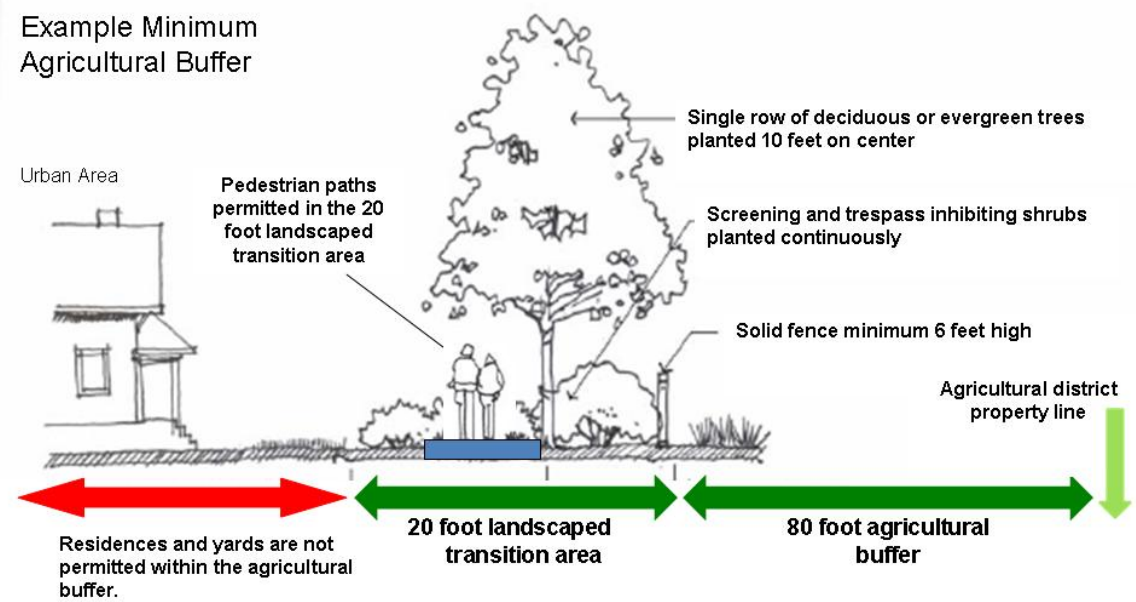

Applies to sites with minimal risk of conflict. Vegetation should have between $50-75 \%$ porosity. Drought tolerant native species should be used and mature height of trees should be at least 15 feet. Pedestrian paths are permitted within the 20 foot landscaped transition area.

Image Source: City of Abbottsford Canada

Figure 1.12 - Example Moderate Buffer Schematic

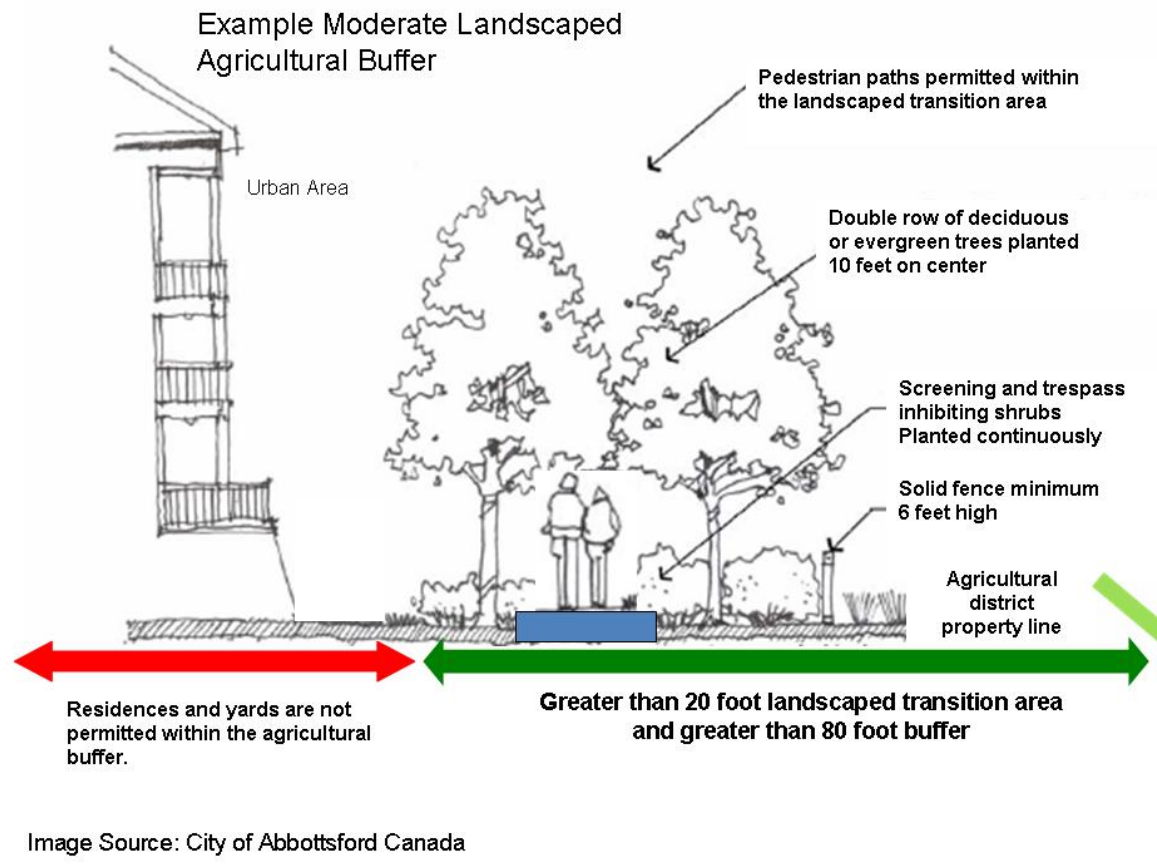


Figure 1.13 - Example Maximum Buffer Schematic

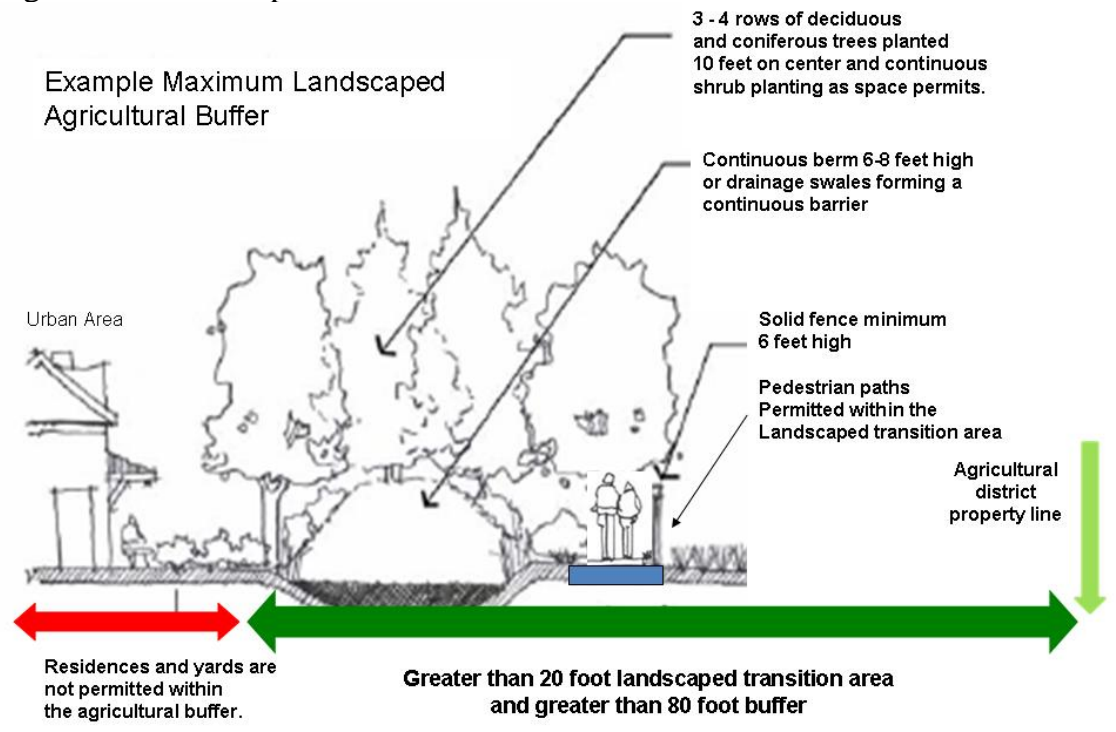

Image Source: City of Abbottsford Canada 


\section{Chapter 7}

\subsection{Concluding Remarks}

\section{Project Summary}

The process by which cities and counties approach agricultural land conservation and the mitigation of conflict at the rural/urban interface is inherently unique. Environmental, social and political factors all play a role in the development, implementation and enforcement of policies to conserve farmland and reduce conflict between adjoining land uses. A strong agricultural identity illustrated within the General Plan is the foundation for successful buffer policy. General plan policy must, however, be substantiated by clear, directive and enforceable language within the zoning or development code. Right-to-Farm ordinances also play an important role in the reduction of conflict at the urban edge. General plan appendices or specific buffer policy documents such as those adopted by San Luis Obispo, Stanislaus, and Ventura Counties are very helpful to delineate specific minimum standards and provide a forum in which agricultural buffer policy is readily available which may be simpler for applicants and the public than deciphering long passages in the general plan or development code.

The actual development of agricultural buffer policies requires consideration of numerous confounding variables as well as site and project specific variables. Scientific and fact-based policies can help reduce the delineation of arbitrary setbacks or buffer guidelines. Consultation with agricultural resource specialists and representatives from the agricultural community can help to further inform planners and decision makers regarding the nuances of buffering agriculture and residential uses. Knowledge of buffer policies in surrounding jurisdictions is very important particularly for neighboring jurisdictions. A united front of consistent regulation can help cities and counties align agricultural preservation goals when possible. 
Flexibility provisions within agricultural buffer policies are crucial to maintaining correct site-specific analysis and conditioning of development projects adjacent to agricultural land. Conversely, flexibility provisions which do not require sufficient review of buffer alternatives to determine that deviations from required buffer policies will provide equal or greater protection of agricultural land, will undermine the buffering process. The development of agricultural buffer criteria to supplement requirements within the general plan and municipal code can convey clear, understandable expectations for the construction and maintenance of agricultural buffers within a community.

This project provided excellent exposure to the realm of agricultural buffer policy within California cities and counties. Conducting scientific literature review as well as policy review provided substantial experience in the research associated with a policy issue. The exercise of bridging existing research and policy to develop and recommend additional policies in a jurisdiction was extremely informative. This process provided the opportunity to research, analyze and prescribe additional agricultural buffer criteria for incorporation by reference into the City of Arroyo Grande Municipal Code. Given the increasingly fragile nature of agricultural production systems within California and the rapidly disappearing farmland, the ability of people and agriculture to coexist peacefully with one another is of grave importance. Buffers provide one of many tools to reduce agricultural/urban conflict and hopefully this issue will continue to be studied within the field of planning. 


\section{References}

Barry, J. W. (1984) Deposition of Chemical and Biological Agents in Conifers. American Chemical Society Symposium Series 238, 117-37.

British Columbia Ministry of Agricultural Lands. (2003). Vegetative Buffers in British Columbia: An Investigation of Existing Buffers and their Effectiveness in Mitigating Conflict. Retrieved October 15, 2008 from: http://www.agf.gov.bc.ca/resmgmt/sf/publications/Urb_Ag_Buffer_03.pdf

British Columbia Ministry of Agricultural Lands. (2008).Guide to Edge Planning - Promoting Compatibility along Urban-Agricultural Edges. Retrieved October 15, 2008 from: http://www.al.gov.bc.ca/resmgmt/sf/publications/8231002_Guide_to_Edge_Planning.pdf

California Department of Finance. (2008).E-5 City/County Population and Housing Estimates Report. Retrieved March 5, 2009 from: http://www.dof.ca.gov/research/demographic/reports/estimates/e-5_2001-06/

City of Abbotsford British Columbia Canada. (2008). A Landscape Buffering Strategy for the Agricultural-Urban Interface. Retrieved October 7, 2008 from: http://www.abbotsford.ca/AssetFactory.aspx?did=8351

City of Arroyo Grande. (1997). Coordinated Agricultural Support Program (CASP) for the Arroyo Grande Valley. Prepared by Perspective Planning.

City of Arroyo Grande. (2001). General Plan. Arroyo Grande, CA.

City of Arroyo Grande. (2008). Municipal Code Chapter 16.12.170 Right to Farm. Arroyo Grande, CA

City of Davis. (2005). City of Davis Profile. Retrieved March 2, 2009 from: http://cityofdavis.org/aboutdavis/cityprofile/index.cfm?topic=welcome

City of Davis. (2007a). General Plan. Davis, CA

City of Davis. (2007b). Municipal Code Chapter 40A Right to Farm and Farmland Preservation. Davis, CA

City of Napa. (2006). General Plan. Napa, CA.

City of Napa. (2003). Municipal Code Chapter 17.52.040 Agricultural Buffers. Napa, CA.

Copprock, Ray and Kreith, Marcia. (1997) California's Future: Maintaining Viable Agriculture at the Urban Edge. University of California Agricultural Issues Center. University of California, Davis. 
Department of Natural Resources, Local Government and Planning, Queensland Australia. (1997). Planning Guidelines Separating Agricultural and Residential Land Uses. DNRQ Publication No. 97088. Scientific Publishing. Queensland Australia.

Dorr, G., Woods, N. and Craig, I. (1998) Buffer Zones for Reducing Drift from the Application of Pesticides. Paper No. SEAg 98/008, International Conference on Engineering in Agriculture.

Dosskey, Michael G. (2002) Setting Priorities for Research on Pollution Reduction Functions of Agricultural Buffers. Environmental Management. 30(5), 641 - 650.

Hammond, S.V. (2002) Can City and Farm Coexist? The Agricultural Buffer Experience in CA. Great Valley Center Agricultural Transactions Program, University of California Cooperative Extension Program. Modesto, CA. Retrieved online April 19, 2008 from: http://66.42.231/publications/agpubs/buffer_study.pdf

Handel, Mary E. (1994) Conflicts and Solutions When Agricultural Land Meets Urban Development. M.S. Thesis, Department of Human and Community Development, University of California, Davis.

Lowrance, Richard; Dabney, S.; Schultz, R. (2002) Improving Water and Soil Quality $\quad$ with Conservation Buffers. Journal of Soil and Water Conservation, 57(2), 36 - 44

Miller, P.C.H. and Lane, A.G. (1999) Relationship between spray characteristics and drift risk into field boundaries of different structure: Aspects of Applied Biology, Field Margins and Buffer Zones. Ecology, Management and Policy, 54, 45-51.

Napa County. (2008).Napa County Crop Report. Retrieved February 17, 2009 from: http://www.co.napa.ca.us/GOV/Departments/26400/Forms/2008AgriculturalCropReport2 0090407.pdf

Nassauer, Joan I. (1989). Agricultural Policy and Aesthetic Objectives. Journal of Soil and Water Conservation. 44(5), 384 - 387

Owens, P.N.; Duzant, J.H.; Deeks, L.K.; Wood, G.A.; Morgan, R.P.; Collins, A.J. (2007) Evaluation of Contrasting Buffer Features Within an Agricultural Landscape for Reducing Sediment and Sediment-Associated Phosphorous Delivery to Surface Waters. Soil Use and Management. 23(1). 165-175

Popov, V.H.; Cornish, P.S.; Sun, H. (2006) Vegetated Biofilters: The Relative Importance of Infiltration and Adsorption in Reducing Loads of Water-Soluble Herbicides in Agricultural Runoff. Agriculture, Ecosystems \& Management. 114(2), 351

Provincial Agricultural Land Commission of British Columbia. (1993). Landscaped Buffer Specifications. Retrieved November 2, 2008 from: http://www.alc.gov.bc.ca/publications/buffer/lbs_main.htm 
Ryan, Robert L. (2002) Preserving Rural Character in New England: Local Residents' Perceptions of Alternative Residential Development. Landscape and Urban Planning. 61, $19-35$.

San Luis Obispo County (2005). Agricultural Buffer Policies and Procedures. Retrieved March 1, 2009 from: http://www.slocounty.ca.gov/AssetFactory.aspx?did=13199

San Luis Obispo County. (2006). County Approved Plant List. Retrieved March 1, 2009 from: http://www.slocounty.ca.gov/AssetFactory.aspx?did=3429

San Luis Obispo County. (2007a). General Plan. San Luis Obispo County, CA.

San Luis Obispo County. (2007b). San Luis Obispo County Crop Report.

Retrieved February 22, 2009 from:

http://www.slocounty.ca.gov/Assets/AG/croprep/Crop_Report_for_the_Year_2007.pdf

Sloots, K.; Van der Vlies, A.W. (2007) Emission Reduction by Multipurpose Buffer Strips on Arable Fields. Water Science and Technology. 56(1), 81-88

Spillman, J. J. and Woods, N. (1989) cited by Dorr, G., Woods, N. and Craig, I. (1998) Buffer Zones for Reducing Drift from the Application of Pesticides. Paper No. SEAg 98/008, International Conference on Engineering in Agriculture. Perth, Western Australia.

Spray Drift Task Force. (1997). Retrieved March 1, 2009 from: www.agdrift.com

Stanislaus County. (2007a). General Plan. Stanislaus County, CA.

Stanislaus County. (2007b). Stanislaus County Crop Report. Retrieved February 25, 2009 from:http:/www.stanag.org/ag/croprpts/croppdf/2007-crop-report.pdf

Sullivan, William C.; Anderson, Olin M.; and Lovell, Sarah Taylor. (2004) Agricultural Buffers at the Rural-Urban Fringe: An Examination of Approval by Farmers, Residents and Academics in the Midwestern United States. Landscape and Urban Planning, 69(2), 299

Sullivan, William C.; Lovell, Sarah Taylor. (2006) Environmental benefits of conservation buffers in the United States: Evidence, promise, and open questions. Agriculture, Ecosystems and Environment, 112, 249-260.

Ventura County. (1997). Right to Farm Ordinance. Retrieved March 1, 2009 from: http://portal.countyofventura.org/pls/portal/docs/PAGE/AGCOMMISSIONER/LAND_U SE_PLANNING/RTF_0.PDF

Ventura County. (2006). Agricultural/Urban Buffer Policy. Retrieved March 6, 2009 from: http://portal.countyofventura.org/pls/portal/docs/PAGE/AGCOMMISSIONER/LAND_U SE_PLANNING/APACBUFFERPOLICY_0.PDF

Ventura County. (2007). Ventura County Crop Report. Retrieved February 20, 2009 from: http://portal.countyofventura.org/pls/portal/docs/PAGE/AGCOMMISSIONER/NEWS/V C\%20CROP\%20REPORT\%202007.PDF 
Ventura County. (2008a). County of Ventura Visitor Information. Retrieved March 3, 2009 from:http://portal.countyofventura.org/portal/page?_pageid=817,1093646\&_dad=portal\& _schema=PORTAL

Ventura County. (2008b). General Plan. Ventura County, CA.

Ventura County. (2008c). SOAR: Questions and Answers. Retrieved March 5, 2009 from: http://portal.countyofventura.org/pls/portal/docs/PAGE/AGCOMMISSIONER/LAND_U SE_PLANNING/SOAR\%20BROCHURE.PDF

Ventura County Ag Futures Alliance. (2003). Issue Paper No.3: Land Use Principles to Achieve Agricultural Sustainability in Ventura County. Retrieved March 5, 2009 from: http://portal.countyofventura.org/pls/portal/docs/PAGE/AGCOMMISSIONER/LAND_U SE_PLANNING/AFALANDUSEPAPER_0.PDF

Ventura County Ag Futures Alliance. (2006). Findings and Recommendations: Follow-Up to Issue Paper No. 3. Retrieved March 5, 2009 from: http://agfuturesalliance.org/files/ Ventura\%20AFA\%20Land\%20Use\%20Report\%20v3_1.pdf

Voller, P. (1999) Growing Trees on Cotton Farms, Rural Industries Research and Development Corporation, Canberra Press. Australia.

Vought, LBM; Pinnay, G.; Fuglsang, A.; Ruffinoni, C. (1995). Structure and Function of Buffer Strips from a Water Quality Perspective in Agricultural Landscapes. Landscape and Urban Planning. 31, 323 - 331.

Yolo County. (2007). Yolo County Crop Report. Retrieved February 20, 2009 from: http://www.yolocounty.org/Index.aspx?page=1419

Zande, J. C., Michielsen, J. M. G. P., Stallinga, H. and de Jong, A. (2004) The Effect of Windbreak Height and Air Assistance on Exposure of Surface Water Via Spray Drift. Proceedings from the British Crop Protection Conference - Pests and Diseases 2004, Brighton, U.K 


\section{Appendices}

A Document Analysis Results - Agricultural Buffer Policies in CA

B City of Arroyo Grande, CA

C City of Davis, CA

D City of Napa, CA

E San Luis Obispo County, CA

F Stanislaus County, CA

G Ventura County, CA 


\section{Appendix A}

Document Analysis Results - Agricultural Buffer Policies in CA 


\section{DRAFT Summary of Agricultural Buffer widths and requirements (as of December, 2008)}

\begin{tabular}{|c|c|c|}
\hline Jurisdiction & Buffer & Notes \\
\hline $\begin{array}{l}\text { GENERAL } \\
\text { SUMMARY }\end{array}$ & \multicolumn{2}{|c|}{$\begin{array}{l}\text { Buffers for California cities generally range from } 0-300 \mathrm{ft} \text {. or are case specific. Buffers in California counties generally range from } 0-800 \mathrm{ft} \text {. (County } \\
\text { of SLO.) Many communities have no minimum (Kern and Ventura, City of Santa Maria) and some have a minimum range (Sonoma, Santa Cruz } \\
\text { counties, City of AG, Davis, Petaluma.) The majority require a landscape/vegetative component and allow modification for special circumstances. }\end{array}$} \\
\hline \multicolumn{3}{|c|}{ 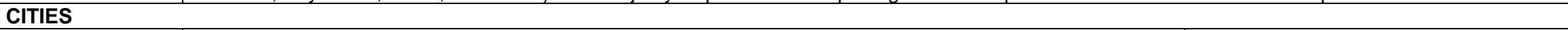 } \\
\hline $\begin{array}{l}\text { 1.) City of Arroyo } \\
\text { Grande }\end{array}$ & $\begin{array}{l}\text { Minimum } 100 \mathrm{ft} .: \\
\text { More encouraged, less if physical buffer (e.g. AG creek) and OK by County Ag Commissioner: } \\
20 \mathrm{ft} \text {. of buffer landscape strip. }\end{array}$ & $\begin{array}{l}100 \text { ft. buffer overlay district } \\
\text { surrounding all agricultural land within } \\
\text { the City. Intent to preserve long term } \\
\text { viable agriculture as part of city } \\
\text { character. }\end{array}$ \\
\hline $\begin{array}{l}\text { 2.) City of San } \\
\text { Luis Obispo }\end{array}$ & $\begin{array}{l}\text { Buffers associated with new development shall be on the site of the development, rather than on } \\
\text { neighboring land containing the open space resource. Buffers provide distance in the form of setbacks, } \\
\text { within which certain features or activities are not allowed or conditionally allowed. Buffers shall also use } \\
\text { techniques such as planting and wildlife-compatible fencing. Buffers shall be adequate for the most } \\
\text { sensitive species in the protected area, as determined by a qualified professional and shall complement the } \\
\text { protected area's habitat values. Buffers shall be required in the following situations: C. Between agricultural } \\
\text { operations and natural habitat, to address noise, chemical use, sediment transport, and livestock access. }\end{array}$ & $\begin{array}{l}\text { Can be modified or waived if there are } \\
\text { significant topographical differences, a } \\
\text { barrier of vegetation capable of } \\
\text { eliminating potential adverse impacts } \\
\text { associated with agriculture on adjacent } \\
\text { development, or existing physical } \\
\text { barriers between the urban } \\
\text { development and the agricultural land. } \\
\text { A mitigation fee to purchase agricultural } \\
\text { protection elsewhere within the } \\
\text { Greenbelt may be provided if a } \\
\text { developer cannot provide an adequate } \\
\text { agricultural buffer. }\end{array}$ \\
\hline $\begin{array}{l}\text { 3.) City of Paso } \\
\text { Robles }\end{array}$ & $\begin{array}{l}\text { General Plan Policy 2003: Establishment of agricultural buffer easements, berms and/or vegetative } \\
\text { screening, on property proposed for urban development as a condition of approval of discretionary } \\
\text { development applications. }\end{array}$ & \\
\hline $\begin{array}{l}\text { 4.) City of } \\
\text { Brentwood }\end{array}$ & $\begin{array}{l}\text { Policy to require a buffer but no set standard. Generally range 100-300 ft. May be implementing } 75 \mathrm{ft} \text {. } \\
\text { width that can vary on case by case. }\end{array}$ & \\
\hline 5.) City of Salinas & $\begin{array}{l}\text { Buffers Encourage the provision and maintenance of buffers, such as roadways, topographicfeatures, and } \\
\text { open space, to prevent incompatibilities } \\
\text { between agricultural and non-agricultural land uses. A number of factors shall be used to determine the } \\
\text { appropriate buffer, including type } \\
\text { of agricultural use, topography, and pesticide and machinery use, } \\
\text { among others. }\end{array}$ & \\
\hline 6.) City of Napa & $\begin{array}{l}\text { Agricultural setback between } 80-120 \mathrm{ft} \text {. (with } 20 \mathrm{ft} \text {. landscape area) is required between dwellings and } \\
\text { nearest agricultural property line as follows: } \\
0-6 \text { units }=80 \mathrm{ft} \text {. } \\
6-10 \text { units }=100 \mathrm{ft} \text {. }\end{array}$ & $\begin{array}{l}\text { Can be modified, reduced or waived } \\
\text { upon consent of Agricultural } \\
\text { Commissioner where it can be } \\
\text { demonstrated that no conflicts will }\end{array}$ \\
\hline
\end{tabular}




\begin{tabular}{|c|c|c|}
\hline Jurisdiction & Buffer & Notes \\
\hline & $>10$ units+120 ft. & $\begin{array}{l}\text { result, conflicts are otherwise mitigated } \\
\text { (e.g. physical buffer via creek or road) } \\
\text { or where the requirement would } \\
\text { preclude the use of the property. }\end{array}$ \\
\hline $\begin{array}{l}\text { 7.) Town of } \\
\text { Esparato }\end{array}$ & $\begin{array}{l}\text { Where new development adjoins agricultural lands, it shall be set back a minimum of } 100 \text { feet. A setback of } \\
300 \text { feet shall be required for urban uses that adjoin Agricultural Preserves or active orchards except where } \\
\text { the adjacent property owner agrees in writing that the } 300 \text { foot buffer is not needed. In no case shall the } \\
\text { buffer be reduced to less than } 100 \text { feet .... Such setback or buffer area shall be established by recorded } \\
\text { easement or other instrument, subject to the approval of County Counsel. A method and mechanism for } \\
\text { guaranteeing the maintenance of this land in a safe and orderly manner shall be also established at the } \\
\text { time of development approval. Options include creating a homeowners association, or dedication of the } \\
\text { buffer area to a non-profit organization or public entity. }\end{array}$ & \\
\hline $\begin{array}{l}\text { 8.) City of El } \\
\text { Centro }\end{array}$ & $\begin{array}{l}\text { COS-2: Agricultural Buffers: Encourage the provision and maintenance of buffers, such as roadways, } \\
\text { topographic features, and open space, to prevent incompatibilities between agricultural and non-agricultural } \\
\text { land uses. During the development review process, a number of factors shall be used to determine the } \\
\text { appropriate buffer, including the type of agricultural use, topography, and pesticide and machinery use. }\end{array}$ & \\
\hline 9.) City of Sanger & $\begin{array}{l}\text { General Plan provides goals and policies regarding Ag buffers or greenbelts. No specific city regulation on } \\
\text { "Ag buffers", but do have an urban reserve zone district that is used for undeveloped non urban areas (Ag } \\
\text { being the prominent one) that are planned (prezoned or land use designated) for future development that } \\
\text { do not yet have services available or that urbanized expansion is not immediate or necessary. }\end{array}$ & \\
\hline $\begin{array}{l}\text { 10.) City of } \\
\text { Goleta }\end{array}$ & $\begin{array}{l}\text { New development adjacent to property designated for agricultural uses shall include buffers and other } \\
\text { measures such as landscape screening to minimize potential conflicts with agricultural activities. The widths } \\
\text { of the buffers shall be determined based on site-specific findings at the time of approval of the } \\
\text { development. }\end{array}$ & 2006 General Plan \\
\hline 11.) City of Davis & $\begin{array}{l}\text { The City of Davis requires agricultural buffers of } 150 \text { feet with public uses being discouraged in the } 100 \text { feet } \\
\text { closest to the agricultural operation, while the last } 50 \text { feet can used as a transitional area that can support } \\
\text { uses such as bike trails and paths }\end{array}$ & $\begin{array}{l}\text { Note: Fundamental change in mitigation } \\
\text { policy (in code) effective December } \\
2007 \text { requiring a } 1 / 4 \text { mile agricultural } \\
\text { conservation easement for new projects } \\
\text { (generally annexations) at edge of City } \\
\text { to allow focus on agricultural lands } \\
\text { under greatest threat to preserve over } \\
\text { time an urban limit line. }\end{array}$ \\
\hline $\begin{array}{l}\text { 12.) City of } \\
\text { Ventura }\end{array}$ & $\begin{array}{l}\text { Requires performance standards for non-farm activities in agricultural areas that protect farm operations, } \\
\text { including requiring non-farm uses to provide all appropriate buffers as determined by the Agriculture } \\
\text { Commissioner's Office. }\end{array}$ & 2005 General Plan \\
\hline $\begin{array}{l}\text { 13.) City of Half } \\
\text { Moon Bay }\end{array}$ & Use of existing roadways and highways as buffer on perimeter of City. & $\begin{array}{l}\text { Consistent w/Coastal Act: Intent to } \\
\text { reduce conflicts between City growth } \\
\text { and County agricultural lands at } \\
\text { Urban/Rural Boundary. Protection of } \\
\text { approx. } 100 \text { acres for floriculture/ }\end{array}$ \\
\hline
\end{tabular}




\begin{tabular}{|c|c|c|}
\hline Jurisdiction & Buffer & Notes \\
\hline & & $\begin{array}{l}\text { Horticulture business. Allowing } \\
\text { remaining Agriculture within City some } \\
\text { short-term protections under Open } \\
\text { Space Reserve designation but to } \\
\text { phase/convert over the long term to } \\
\text { urban uses. }\end{array}$ \\
\hline $\begin{array}{l}\text { 14.) City of } \\
\text { Ontario }\end{array}$ & $\begin{array}{l}\text { Minimum of } 100 \mathrm{ft} \text {. between new residential, commercial, public assembly or industrial development and } \\
\text { exiting farm operations. }\end{array}$ & \\
\hline $\begin{array}{l}\text { 15.) City of } \\
\text { Oakley }\end{array}$ & $\begin{array}{l}\text { General Plan Conservation element provides policies to incorporate parks, open space and trails between } \\
\text { urban and agricultural uses to provide buffer and transition between uses. }\end{array}$ & \\
\hline $\begin{array}{l}\text { 16.) City of } \\
\text { Fairfield }\end{array}$ & $\begin{array}{l}\text { The City, in cooperation with the County, shall establish similar buffers between productive permanent } \\
\text { agricultural lands and development in other areas undergoing development. Solano County currently } \\
\text { requires a minimum } 300 \text { foot buffer between agricultural and non-agricultural uses (2008 General Plan). }\end{array}$ & \\
\hline \multicolumn{3}{|l|}{ COUNTIES } \\
\hline $\begin{array}{l}\text { 1.) Santa Barbara } \\
\text { County }\end{array}$ & $\begin{array}{l}\text { New development adjacent to agriculturally zoned property shall include buffers to protect agricultural } \\
\text { operations. Buffers composed of predominantly native and low water using species, or other appropriate } \\
\text { perimeter screening, such as fences and walls, shall be required, the size of which will be determined by } \\
\text { parcel specific review for all new development adjacent to agriculturally zoned property. }\end{array}$ & \\
\hline $\begin{array}{l}\text { 2.) Sonoma } \\
\text { County }\end{array}$ & $\begin{array}{l}\text { Buffers shall generally be defined as a physical separation of } 100 \text { ' to } 200^{\prime} \text { and/or may be topographic } \\
\text { feature, a substantial tree stand, watercourse or similar feature. In some circumstances a landscaped } \\
\text { berm may provide the buffer. The buffer shall occur on the parcel for which a permit is sought and shall } \\
\text { favor protection of the maximum amount of farmable land. The requirement for buffer may be modified } \\
\text { after hearing by the advisory agency following a written recommendation by the agricultural commissioner. }\end{array}$ & \\
\hline $\begin{array}{l}\text { 3.) County of } \\
\text { Butte }\end{array}$ & $300 \mathrm{ft} . \mathrm{b} / \mathrm{t}$ City's and unincorporated county lands & $\begin{array}{l}\text { Can be larger or smaller depending on } \\
\text { unusual circumstances of lot } \\
\text { development }\end{array}$ \\
\hline 4.) Sutter County & \multicolumn{2}{|c|}{$\begin{array}{l}\text { Buffers are required for any new "project" which proposes to locate adjacent to an existing or zoned agricultural use or a "project" which proposes to } \\
\text { expand its use through the granting of additional entitlements from the County and is located adjacent to an agricultural use. Buffers should be } \\
\text { located on the parcel proposed for non-agricultural use. In general, only non-habitated structures, and no residential structures will be allowed within } \\
\text { the setback zone. Other compatible uses may be allowed within the buffer area as determined by the County. The appropriate buffer distance shal } \\
\text { be determined on a site-by-site basis taking into account the type of existing agricultural uses, the nature of the proposed development, the natural } \\
\text { features of the site, and any other factors that may affect the specific buffering needs. Buffer distances range from } 50 \text { ' to } 300 \text { ' depending on the type } \\
\text { of agricultural use. } \\
\text { Eg. Mitigation: } 300 \text { residential exclusion area buffer w/o landscaping OR a } 100 \text { ft. buffer with The buffers will consist of either a } 300 \text {-foot-wide } \\
\text { residential exclusion area that does not contain landscaping or a } 100 \text {-foot-wide residential exclusion area containing a } 25 \text {-footwide landscape planting } \\
\text { area. }\end{array}$} \\
\hline 5.) Contra Costa & & \\
\hline
\end{tabular}




\begin{tabular}{|c|c|c|}
\hline Jurisdiction & Buffer & Notes \\
\hline County & \multicolumn{2}{|l|}{ presence of sensitive land uses (schools.) } \\
\hline 6.) Yolo County & \multicolumn{2}{|c|}{$\begin{array}{l}\text { With the exception of individual residences appurtenant to active farming operations, where new urban (non-agricultural) development is approved } \\
\text { adjacent to agricultural lands, it shall be set back a minimum of } 150 \text { feet. A setback of } 300 \text { feet shall be required for urban uses that adjoin agricultural } \\
\text { preserves or active orchards, except where the adjacent property owner agrees in writing that the } 300 \text {-foot buffer is not needed. In no case shall the } \\
\text { buffer be reduced to less than } 100 \text { feet. }\end{array}$} \\
\hline 7.) Ventura Co. & $\begin{array}{l}\text { New dwellings, non-agricultural work sites and ongoing outdoor public activities potentially conflict with agricultural } \\
\text { operations. A buffer/setback and fencing are therefore needed on these sites when they are developed adjacent to } \\
\text { the qualifying agricultural land. A 300-foot setback to new structures and sensitive uses is required on the non- } \\
\text { agricultural property unless a vegetative screen is installed. With a vegetative screen the buffer/setback is a } \\
\text { minimum of 150-feet. }\end{array}$ & Revised 7/06 \\
\hline 8.) County of SLO & \multicolumn{2}{|c|}{$\begin{array}{l}\text { Buffers range from } 400-800 \text { feet for vineyards, } 300 \text { to } 800 \text { feet for irrigated orchards and } 100 \text { to } 400 \text { feet for field crops. The buffer distance is usually } \\
\text { determined on a case-by-case basis depending upon variables, such as prevailing wind direction, type of crop, surrounding zoning, and topography. }\end{array}$} \\
\hline $\begin{array}{l}\text { 9.) Monterey } \\
\text { County }\end{array}$ & \multicolumn{2}{|c|}{$\begin{array}{l}200 \text { feet from property identified as Agricultural Land or on which commercial agricultural activities are being conducted. Less than } 200 \mathrm{ft} \text { may be } \\
\text { permitted if one or more of the following special circumstances exist: significant topographic differences, roads or other physical or vegetative barrier. } \\
\text { Not less than } 50 \mathrm{ft} \text {. buffer required adjacent to agricultural areas not designated for exclusive agricultural use. } \\
\text { buildings/sheds may be permitted as a conditioned use. }\end{array}$} \\
\hline $\begin{array}{l}\text { 10.) Mendocino } \\
\text { County }\end{array}$ & \multicolumn{2}{|c|}{$\begin{array}{l}\text { To minimize agricultural-residential conflicts, land divisions or site plans in a residential area shall not result in a residential structure being closer than } \\
200 \text { ' from a parcel designated for agricultural use unless there is no other feasible building site on the parcel. }\end{array}$} \\
\hline $\begin{array}{l}\text { 11.) Sacramento } \\
\text { County }\end{array}$ & \multicolumn{2}{|c|}{$\begin{array}{l}\text { Agricultural buffers shall generally consist of a physical separation } 300 \text { '-500' wide including roadways; narrower buffers may be approved depending } \\
\text { on the natural features of the buffer, applicable specific plan policies and on the relative intensities of the proposed urban use and the adjacent } \\
\text { agricultural use. Guidelines for maintenance of buffers are required, including, but not limited to, the following criteria: the County, a homeowners } \\
\text { association, or other appropriate entity shall maintain buffers to control litter, fire hazards, and pests; compatible agriculture shall be allowed on } \\
\text { buffers; and buffers may be removed once agricultural uses on all adjacent parcels have permanently ceased. }\end{array}$} \\
\hline
\end{tabular}




\begin{tabular}{|c|c|}
\hline Jurisdiction & uffer \\
\hline $\begin{array}{l}\text { 12.) Santa Cruz } \\
\text { County }\end{array}$ & $\begin{array}{l}200 \text { ft. agricultural buffer required between Type } 1,2 \text { or } 3 \text { commercial agricultural land and non-agricultural uses involving habitable spaces. The two } \\
\text { hundred (200) foot agricultural buffer setback shall incorporate vegetative or other physical barriers as determined necessary to minimize potential } \\
\text { land use conflicts. Outside of the Coastal Zone, notwithstanding the provisions of subsection (b) of this section an agricultural buffer setback distance } \\
\text { of less than two hundred (200) feet may be established for subdivision developments involving habitable uses on proposed parcels adjacent to lands } \\
\text { designated as an Agricultural Resource by the County's General Plan maps, provided that, (1) The proposed land division site is: (A) Located within } \\
\text { the Urban Services Line, (B) Suitable for development at buildout level within the carrying capacity of the area; and (2) The Agricultural Policy } \\
\text { Advisory Commission (APAC) finds special circumstances exist e.g. topographic or physical barriers, or the imposition of the two hundred (200) foot } \\
\text { agricultural buffer setback would, in a definable manner, hinder: infill development or the development of a cohesive neighborhood, or otherwise, } \\
\text { create a project incompatible with the character and setting of the existing surrounding residential development; and an APAC determination. An } \\
\text { agricultural setback distance of less than two hundred (200) feet may be established for developments involving habitable uses on existing parcels of } \\
\text { record under special circumstances e.g. significant topographic differences or a lesser setback distance is found to be adequate to prevent conflicts } \\
\text { between the non-agricultural development and the adjacent agricultural development and the adjacent agricultural land, based on the establishment } \\
\text { of a physical barrier. }\end{array}$ \\
\hline 13.) $\mathrm{N}$ & $\begin{array}{l}\text { Required Provisions. Except as provided in subsection E of this section, the following provisions shall be required for all residentially zoned } \\
\text { lots adjacent to the Rural Urban Limit (RUL) line when development is proposed. } \\
\text { 1. An agricultural buffer plan to address the following requirements: } \\
\text { a. Setback: A special agricultural setback of between } 80 \text { and } 120 \text { feet wide between any dwellings or other buildings designed for } \\
\text { human habitation and the nearest residential property line(s) adjoining the RUL. The exact distance shall be based on the overall density of } \\
\text { the proposed residential project as follows: } \\
\qquad>0-6 \text { units/acre }=80 \text { foot setback } \\
\qquad \begin{array}{l}> \\
\text { (10 units/acre }=100 \text { foot setback }\end{array} \\
\qquad 10 \text { units/acre }=120 \text { foot setback } \\
\text { Within the special agricultural setback, a permanent landscape buffer area at least } 20 \text { feet wide measured from the residential property line(s) } \\
\text { adjoining the RUL and nearest agricultural property line(s) shall provide a clear boundary between urban and agricultural uses. } \\
\text { Requirement may be waived for projects where it can be clearly demonstrated that no agricultural-urban residential land use conflicts will result from } \\
\text { the development of the property or where the requirement for an agricultural buffer plan meeting the above requirements would preclude the use of the } \\
\text { property. In particular, the agricultural setback between any dwellings or other buildings designed for human habitation and the nearest residential } \\
\text { property line(s) adjoining the RUL may be reduced where off-site roads, creeks or rivers provide additional setback distance between residential uses } \\
\text { and agricultural activities. } \\
\text { Further, the requirements of this section are waived for construction within an existing dwelling involving no expansion. }\end{array}$ \\
\hline $\begin{array}{l}\text { 14.) El Dorado } \\
\text { County }\end{array}$ & $\begin{array}{l}\text { Agriculturally incompatible uses adjacent to agricultural zoned lands within designated agricultural districts shall provide a minimum setback of } 200 \text { ' } \\
\text { from the boundary of the agriculturally zoned lands. Agriculturally incompatible uses adjacent to agriculturally zoned land outside of designated } \\
\text { agricultural districts shall provide a minimum setback of 200' of parcels } 10 \text { acres or larger. Administrative relief to these setbacks may be granted by } \\
\text { the County Planning Director, where appropriate. The Agricultural Commission may recommend a lesser setback to a minimum of } 100 \text { '. Projects } \\
\text { located within a Community Region or Rural Center planning concept area shall maintain a minimum setback of 50'. The 50' setback shall only apply } \\
\text { to incompatible uses including residential structures. }\end{array}$ \\
\hline $\begin{array}{l}\text { 15.) Tuolumne } \\
\text { County }\end{array}$ & $\begin{array}{l}\text { istruction of new residential/non-agricultural buildings, resulting from development closer than 200' from the boundary of a parcel classified } \\
\text { e agricultural land or agricultural land of local importance. This setback may be reduced by the Planning Director, with the concurrence of } \\
\text { ural Advisory Committee. }\end{array}$ \\
\hline 16.) Stanis & 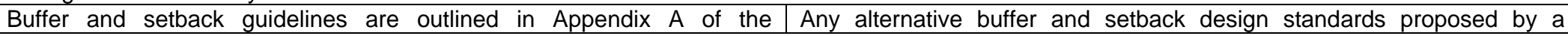 \\
\hline
\end{tabular}




\begin{tabular}{|c|c|c|}
\hline Jurisdiction & Buffer & Notes \\
\hline County & $\begin{array}{l}\text { Agriculture Element of the General Plan and apply to all new or } \\
\text { expanding non-agricultural uses approved by discretionary permit in or } \\
\text { adjoining the A-2 district. A minimum } 150 \text { foot wide buffer. Projects which } \\
\text { propose people intensive outdoor activities such as athletic fields must } \\
\text { incorporate a } 300 \text { foot buffer. All buffers shall incorporate a solid wall and } \\
\text { vegetative screen consistent with the following standards: } \\
\text { Fencing: A } 6 \text {-foot high solid wall of uniform construction shall be installed } \\
\text { along any portion of a buffer where the project site and the adjoining } \\
\text { agricultural operation share a common parcel line. } \\
\text { Vegetative Screening (minimum standards): } \\
\text { - Two staggered rows of trees and shrubs characterized by } \\
\text { evergreen foliage extending from the base of the plant to the } \\
\text { crown. Fast growing plants with a short life span shall be } \\
\text { discouraged. } \\
\text { Trees and shrubs should be vigorous, drought tolerant and at } \\
\text { least } 6 \text {-feet in height at the time of installation } \\
\text { Plants shall have } 50-70 \% \text { porosity (approximately } 50 \% \text { to } 75 \% \text { of } \\
\text { the plant is airspace) } \\
\text { Plant height shall vary in order to capture drift within } 4 \text {-feet of } \\
\text { ground application } \\
\text { A mature height of } 15 \text { feet or more shall be required for each } \\
\text { tree } \\
\text { To ensure adequate coverage, two staggered rows shall be } \\
\text { located } 5-f e e t \text { apart and consist of a minimum } 5 \text { gallon plants at } \\
\text { least } 6 \text { feet tall planted } 10 \text { feet on center. Alternative spacing } \\
\text { between rows may be authorized to accommodate the needs of } \\
\text { specific plant species. }\end{array}$ & $\begin{array}{l}\text { project applicant shall be reviewed and supported by the Stanislaus } \\
\text { County Agricultural Advisory Board prior to consideration by the } \\
\text { Stanislaus County Planning Department. In no case, shall the required } \\
\text { standards be reduced, unless the proposed alternative is found to provide } \\
\text { equal or greater protection to surrounding agricultural uses. }\end{array}$ \\
\hline 17.) Yuba County & \multicolumn{2}{|c|}{$\begin{array}{l}\text { New development projects shall incorporate a buffer zone of at least } 300 \text { in depth. This requirement may be eliminated or modified if there are } \\
\text { significant topographical differences, substantial vegetation, or existing physical barriers between urban and agricultural areas. }\end{array}$} \\
\hline $\begin{array}{l}\text { EG mitigation } \\
\text { from Cal State } \\
\text { Channel Islands } \\
\text { AMENDED } \\
\text { FROM THE } 2000 \\
\text { SUPPLEMENTAL } \\
\text { EIR: } \\
\text { SO3-AG-23(a) } \\
\text { Use Buffer for } \\
\text { Buildings and } \\
\text { Athletic } \\
\text { Fields. }\end{array}$ & \multicolumn{2}{|c|}{$\begin{array}{l}\text { Where building or athletic fields would be within } 300 \text { feet of agricultural operations, a 100-foot buffer use buffer shall be created along the project site's } \\
\text { property line facing agricultural operations. A minimum } 150 \text {-foot setback (in conjunction with a vegetative buffer) or } 300 \text {-foot setback (without } \\
\text { vegetative buffer) between any occupied campus structures, uses or athletic facilities and agricultural production shall be provided. The buffer may } \\
\text { include roads and landscaped areas, and internal paths. Said buffer shall be located on the project site, and not on the adjacent agricultural } \\
\text { development. If a minimum 150- foot setback with vegetative buffer is selected, said buffer shall consist of two staggered rows of bushes with } 50 \text { to } \\
75 \% \text { porosity }\end{array}$} \\
\hline
\end{tabular}




\section{Appendix B}

\section{City of Arroyo Grande, CA}

Draft Agricultural Buffer Criteria for the City of Arroyo Grande Agriculture, Conservation and Open Space Element of the General Plan

Section 16.12.107 of the Municipal Code - Right to Farm Provisions 


\title{
Agricultural Buffer Criteria for the City of Arroyo Grande
}

\author{
Adopted by City Council \\ Resolution No. \\ Date \\ ${ }^{\circ}$ 2009, City of Arroyo Grande \\ and Laura Pennebaker \\ All Rights Reserved
}




\section{Table of Contents}

2006 CITY OF ARROYO GRANDE ZONING MAP .............................................................. 3

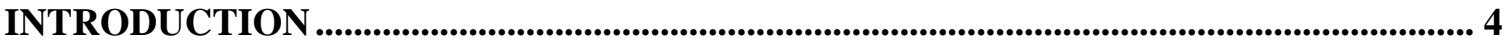

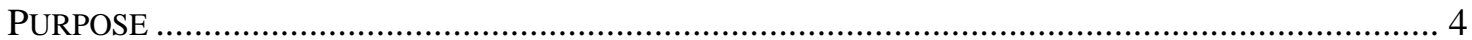

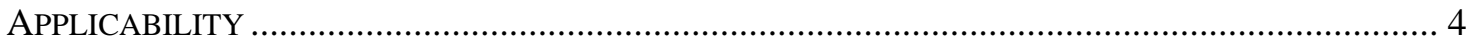

MINIMUM BUFFER REQUIREMENTS .............................................................................. 5

Minimum AgRicultural BUfFER REQUIREMENTS IN THE GENERAL PLAN ............................ 5

Minimum AgRICUlTURAL BUfFER REQUIREMENTS IN THE MUNICIPAL CODE ....................... 5

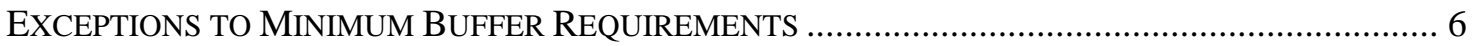

ADDITIONAL CRITERIA FOR BUFFER DESIGN ............................................................ 7

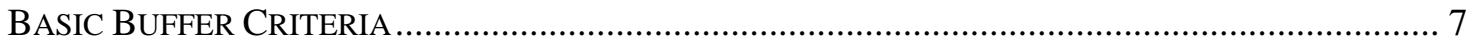

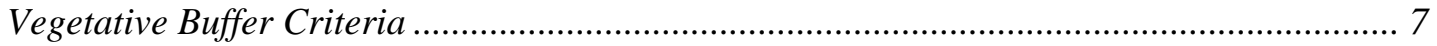

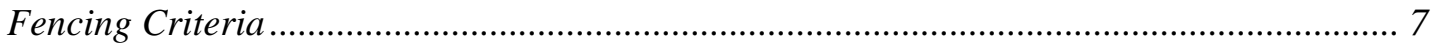

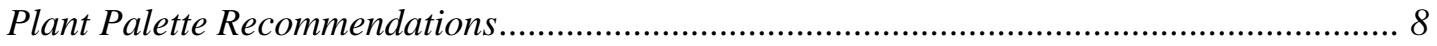

ADDITIONAL MAINTENANCE CRITERIA....................................................................... 9

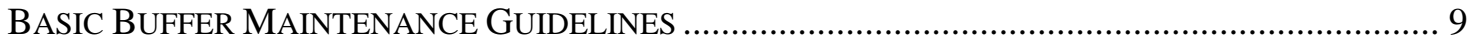

ADDITIONAL SUBMITTAL CRITERIA …............................................................................... 10

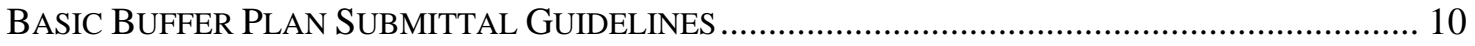

SCHEMATIC BUFFER EXAMPLES ...................................................................................... 11

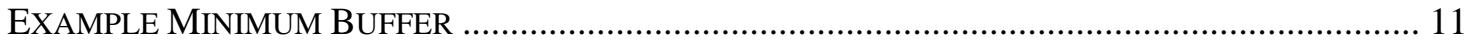

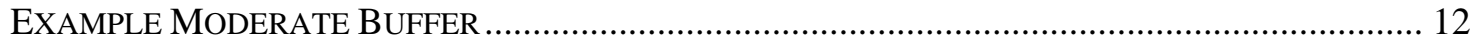

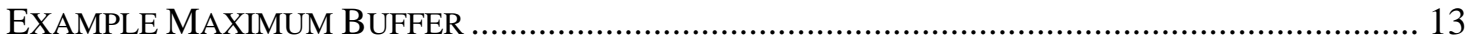

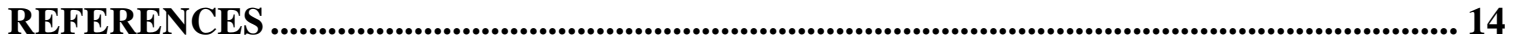




\section{CITY OF ARROYO GRANDE ZONING MAP}

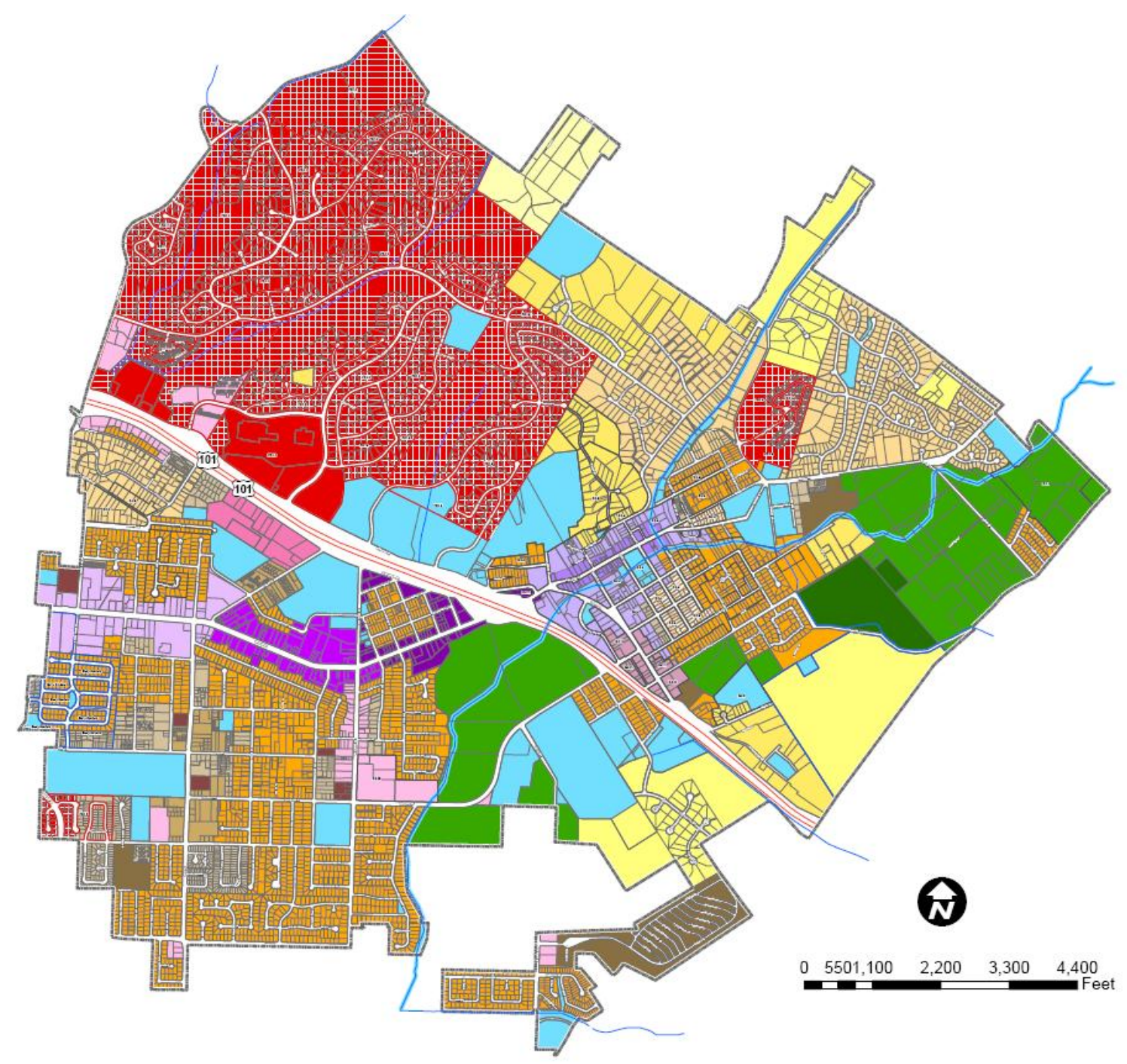

\section{Zoning Districts}

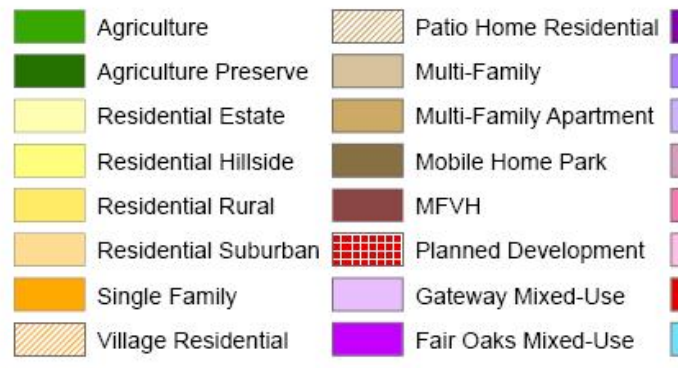

Highway Mixed-Use $\square$ Design Overlay
Village Core Downtown $\square$ Planned Development
Village Mixed Use $\quad \square$ Specific Plan
Traffic Way Mixed-Use
Industrial Mixed-Use
Office Mixed-Use
Regional Commercial
Public Facility




\section{INTRODUCTION}

\section{PURPOSE}

The Agricultural Buffer Criteria are intended to supplement the policies and regulations set forth in the Agriculture, Conservation and Open Space Element of the General Plan as well as Section 16.12.170 of the Municipal Code. These criteria were developed to provide guidance for planners, project applicants and decision makers regarding the construction of an agricultural buffer in the City of Arroyo Grande.

According to Section 16.12.101 E of the Municipal Code, the purpose of the City's agricultural buffer regulations is to minimize potential conflicts between agricultural and non-agricultural land uses including:

- The protection of public health;

- The reduction of noise and odor;

- The reduction of risk to farm operations from domestic animal predation, crop theft and damage and;

- The reduction of complaints from neighboring urban dwellers.

\section{APPLICABILITY}

According to implementation measure AG-5-2.1 of the Agriculture, Conservation and Open Space Element, buffers shall be established on all parcels proposed for non-agricultural development adjacent to agricultural uses, when the property is exposed to agricultural operations. According to Section 16.12.170 E of the Municipal Code, all "new development" adjacent to any designated agricultural zoning district shall be required to provide an agricultural buffer. New development includes the following:

- Subdivision of land;

- Issuance of use permits;

- Issuance of building permits for new residential units.

New development does not include the following:

- Restoration of a damaged residence within the buffer area in accordance with Section 16.48.110 or;

- Remodeling of an existing residence. 


\section{MINIMUM BUFFER REQUIREMENTS}

The General Plan and Municipal Code specifically provide minimum requirements for agricultural buffers as follows:

\section{Minimum Agricultural Buffer Requirements in the General Plan}

The Agriculture, Conservation and Open Space Element of the General Plan specifies the following requirements for agricultural buffers:

AG-5-2.1 Buffers shall be established on all parcels proposed for non-agricultural development adjacent to agricultural uses, when the property is exposed to agricultural operations.

AG-5-2.2 No portion of any new residential structure, within a non-Agricultural land use designation shall be located closer than 100 feet from the site of agricultural operations within an Agricultural land use designation. Greater distances may be required based upon site-specific circumstances.

AG-5-2.3 The buffer area shall be noticed and/or fenced and landscaped in such a manner to discourage human and domestic animal movement between the urban and agricultural areas and to screen urban uses from dust and wind-borne materials.

AG-5-2.4 The buffer area shall contain a minimum 20 foot depth of landscaping. Plantings shall be sufficiently dense and mature to provide aerosol protection within the first year of establishment. Greater landscaping depth may be required based upon site-specific circumstances, to include consideration of established or existing farming operations or practices.

AG-5-2.5 Buffer standards associated with non-residential structures and roadways shall account for the type of use, building orientation, as well as building and roadways design.

\section{Minimum Agricultural Buffer Requirements in The Municipal Code}

Section 16.12.170 E of the Municipal Code specifies the following requirements for agricultural buffers:

E-2 The buffer area shall be a minimum of 100 feet, measured from the edge of the designated agricultural district. Optimally, to achieve a maximum separation, a buffer wider than one hundred feet is encouraged and may be required if it is determined through environmental review under CEQA and/or recommended by the San Luis Obispo County Agricultural Commissioner. A decreased buffer distance may be allowed if it can be demonstrated that a physical buffer exists (e.g. Arroyo Grande Creek) that is adequate and approved by the San Luis Obispo County Agricultural Commissioner.

E-3 The minimum 100 foot buffer area shall be comprised of two components: a 20 foot wide agricultural landscaped transition area contiguous to an 80 foot wide 
agricultural buffer adjacent to the designated agricultural district. The 20 foot landscaped transition area may include pedestrian access. The combined 100 foot agricultural buffer shall not qualify as farmland mitigation as required by Section 16.12.170.F.

E-4 The following uses are permitted in the 100 foot agricultural buffer:

- Native plants

- Trees or hedgerows

- Roads

- Drainage channels

- Stormwater retention ponds

- Natural areas such as creeks or drainage swales

- Utility corridors

- Storage

- Any use (including agricultural, limited commercial and low humanintensity uses), determined by the Planning Commission to be consistent the use of the property as an agricultural buffer.

No new residential use shall be permitted within the buffer area unless it is determined there would be no other economically viable use of the property. Restoration of a damaged residence or remodel of an existing residence within the buffer area may be pursued in accordance with Section 16.48.110.

E-5 The 100 foot agricultural buffer shall be established by the developer pursuant to a plan approved by the community development director and the parks, recreation and facilities director. The plan shall include provisions for the use of integrated weed and pest management techniques and soil erosion control. An agreement in the form approved by the city attorney shall be recorded which shall contain the requirements of this section.

\section{EXCEPTIONS TO MINIMUM BUFFER REQUIREMENTS}

According to the Municipal Code, to achieve a maximum separation, a buffer wider than one hundred feet is encouraged and may be required if it is determined through environmental review under CEQA and/or recommended by the San Luis Obispo County Agricultural Commissioner. A decreased buffer distance may be allowed if it can be demonstrated that a physical buffer exists (e.g. Arroyo Grande Creek) that is adequate and approved by the San Luis Obispo County Agricultural Commissioner. 


\section{ADDITIONAL CRITERIA FOR BUFFER DESIGN}

In addition to the minimum buffer requirements outlined above, the following additional criteria are recommended by the City of Arroyo Grande regarding the design, vegetative, fencing and plant palette components:

\section{BASIC BUFFER CRITERIA}

Agricultural buffers should consist of a mix of trees, shrubs, berms, fences, walls etc. sufficient to reduce noise, spray drift and dust, diffuse light, and act as a physical separation between urban and agricultural uses. All buffers should incorporate a solid, architectural, landscaped wall and vegetative screening component to reduce conflict potential between urban and agricultural uses.

\section{Vegetative Buffer Criteria}

At minimum the following vegetative criteria should be used:

1. Vegetative screen should consist at minimum of 1-2 staggered rows of deciduous or coniferous trees and shrubs (5 gallon size at planting), located 5 feet apart and planted 10 feet on center.

2. Vegetative screen should have between $50-75 \%$ porosity ( $50-75 \%$ of the buffer should be air space).

3. Trees and shrubs should be vigorous, drought tolerant, and at least 6 feet in height at the time of installation.

4. Minimum mature tree height should be 15 feet.

5. Fast growing plants with a short lifespan are discouraged. Species with long, thin, rough foliage are encouraged.

6. Native plant species are preferred.

7. Where the potential for conflict between agricultural and non-agricultural uses is high, additional rows of vegetation and physical screening may be appropriate.

\section{Fencing Criteria}

At minimum the following fencing criteria should be used:

1. Installation of a minimum 6 foot high solid, architectural, landscaped wall or fence where the urban use and agricultural use share a common property line or as needed to prevent trespass between the urban and agricultural areas. 


\section{Plant Palette Recommendations}

Planting recommendations should be determined based upon site-specific circumstances with special emphasis on promoting integrated pest management, low water usage and weed control. County-approved plant species for use in agricultural buffers are outlined below.

San Luis Obispo County Approved Plants for Agricultural Buffers

\begin{tabular}{|c|c|c|c|c|}
\hline Botanical Name & Common Name & Type & CA Native & Water Need \\
\hline Agonis flexuosa & Peppermint Tree & tr & $\mathrm{N}$ & to \\
\hline Arbuts 'Marina' & Marina Arbutus & tr & $\mathrm{N}$ & av \\
\hline Arbutus unedo & Strawberry Tree & tr & $\mathrm{N}$ & to \\
\hline Callistemon (varieties) & Bottlebrush & sh & $\mathrm{N}$ & hi \\
\hline Calocedrus decurrens & Incense Cedar & tr & $\mathrm{Y}$ & to \\
\hline Cedrus deodora & Deodar Cedar & tr & $\mathrm{N}$ & av \\
\hline Choisya ternata & Mexican Orange & sh & $\mathrm{N}$ & 10 \\
\hline Cupressus glabra & Smooth Arizona Cypress & tr & $\mathrm{N}$ & to \\
\hline Garrya elliptica & Coast silk-tassel bush & sh/tr & $\mathrm{Y}$ & to \\
\hline Geijera parviflora & Australian Willow, Wilga & tr & $\mathrm{N}$ & av \\
\hline Grevillea (varieties) & Grevillea & $\mathrm{tr} / \mathrm{sh}$ & $\mathrm{N}$ & 10 \\
\hline Hakea suaveolens & Sweet Hakea & sh & $\mathrm{N}$ & to \\
\hline Hetromeles arbutifolia & Toyon, Christmas Berry & $\mathrm{sh} / \mathrm{tr}$ & Y & lo \\
\hline Lingustrum lucidum & Glossy Privet & tr & N & hi \\
\hline Melaleuca (varieties) & Melaleuca & sh/tr & $\mathrm{N}$ & lo \\
\hline Metrosiderous excelsus & New Zealand Christmas Tree & tr & $\mathrm{N}$ & lo \\
\hline Photinia fraseri & Photinia & sh & $\mathrm{N}$ & av \\
\hline Pittosporum (varieties) ${ }^{\star \star}$ & Pittosporum & sh/tr & $\mathrm{N}$ & av \\
\hline Prunus caroliniana & Carolina Laurel Chetty & sh/tr & $\mathrm{N}$ & to \\
\hline Prunus ilicifolia & Holly-leaf Cherry & sh/tr & $\mathrm{Y}$ & 10 \\
\hline Prunus lyonii & Catalina Cherry & sh/tr & $\mathrm{Y}$ & 10 \\
\hline Quercus agrifola & Coast Live Oak & tr & Y & lo \\
\hline Quercus chrysolepsis & Canyon Live Oak & tr & $\mathrm{Y}$ & lo \\
\hline Quercus engelamnnii & Mesa Oak & tr & $\mathrm{Y}$ & lo \\
\hline Quercus wislizenii & Interior Live Oak & $\operatorname{tr}$ & $\mathrm{Y}$ & 10 \\
\hline Rhamnus californica & Coffeeberry & sh & $\mathrm{Y}$ & 10 \\
\hline Rhapiolepsis & Majestic Beauty & sh & $\mathrm{N}$ & 10 \\
\hline Rhus integrifolia & Lemonade Berry & sh & $\mathrm{Y}$ & 10 \\
\hline Rhus ovata & Sugar Bush & sh & $\mathrm{Y}$ & lo \\
\hline
\end{tabular}

\begin{tabular}{|c|c|c|}
\hline $\begin{array}{l}\text { Growth Rate } \\
\text { mod - fast }\end{array}$ & $\begin{array}{l}\text { Climate } \\
15-17,20-24\end{array}$ & Other \\
\hline slow & $8,9,14-24$ & oak root fungus resistant \\
\hline \multirow[t]{3}{*}{ slow } & 4 thru 24 & oak root fungus resistant, bears fruit \\
\hline & $8,9,12-24$ & C. viminalis good for $\mathrm{S} / \mathrm{W}$ exposure \\
\hline & $1-12,14-24$ & slow growth then 2' per year \\
\hline fast & $2-12,14-24$ & good inland plant \\
\hline fast & $7-9,12-17$ & \\
\hline fast & 5,8 thru 24 & wind resistant, good wildlife and inland plant \\
\hline mod - fast & $5-9,14-21$ & good with oaks, near coast, wildlife, tolerate deer \\
\hline mod & $8,913-24$ & resistant to oak fungus \\
\hline mod - fast & varies & good for $S / W$ exposure \\
\hline fast & $9,12-17,19-24$ & good for sea coasts \\
\hline slow - mod & 5 thru 24 & good with oaks, good wildlife cover \\
\hline fast & $5,6,8-24$ & wind resistant, potentially invasive, messy fruit \\
\hline fast & varies & NOT M. linariifolia (highly ignitable) \\
\hline mod & $17,23,24$ & (Tormentosus) \\
\hline $\bmod$ & 4 thru 24 & caution around animals, good for $S W$ exposure \\
\hline slow - mod & varies & \\
\hline fast & 7 thru 24 & caution around animals, good for $S \mathrm{~W}$ exposure \\
\hline mod & $7-9,12-24$ & resistant to oak fungus, good with oaks, wildlife \\
\hline $\bmod$ & $7-9,12-24$ & resistant to oak fungus, caution around animals \\
\hline $\bmod$ & $7-10,12,14-24$ & good wildlife and inland plant \\
\hline $\bmod$ & $5-9,14-24$ & good wildlife and inland plant \\
\hline slow - mod & $18-24$ & good wildlife and inland plant \\
\hline \multirow[t]{5}{*}{ slow - mod } & $7-9,14-16,1-21$ & good wildlife and inland plant \\
\hline & 4 thru 24 & good with oaks \\
\hline & $4-10,12-24$ & \\
\hline & $15-17,20-24$ & \\
\hline & 7 thru 24 & heat tolerant \\
\hline
\end{tabular}

*P.crassifolium, P.undulatum, P.tobira, P.eugenioides, P.rhombifolium 


\section{ADDITIONAL MAINTENANCE CRITERIA}

Municipal Code provisions stipulate that an agreement in the form approved by the City attorney shall be recorded which include the requirements of section 16.12.170 E. Basic agricultural buffer maintenance guidelines as outlined below should also be included as project conditions.

\section{BASIC BufFer MaINTENANCE GUIDELINES}

- Property owner(s) are responsible for all aspects of on-going maintenance of buffer and setback areas.

- Property owner(s) shall be responsible for maintaining landscape plants in a healthy and attractive condition. Dead or dying plants shall be replaced with materials of equal size and similar variety within 30 days of weather permitting.

- A Homeowners Association or other responsible entity shall be required to maintain buffers to control litter, fire hazards, pests, and other maintenance problems when a project consists of multiple parcels which may be held under separate ownership.

- Buffer maintenance requirements shall be stipulated through inclusion in Covenants, Conditions and Restrictions (CC\&Rs) or through deed restriction. 


\section{ADDITIONAL SUBMITTAL CRITERIA}

In addition to the submittal requirements outlined in Section 12.16.170 E.5 of the Municipal Code, the following submittal guidelines are encouraged to ensure that review and processing of project applications requiring agricultural buffers is efficient and effective.

\section{Basic Buffer Plan Submittal Guidelines}

- Name and address of owner, property location and Assessor's Parcel Number.

- North arrow and scale as well as the name and location of the nearest public road intersection.

- Name, address, professional status, license number, and phone number of the person who prepared the plan.

- Site plan should clearly show the special agricultural buffer in relation to property lines adjacent to the agricultural district, adjacent property lines, public streets and other features such as creeks as well as lots, building envelopes and any proposed buildings.

- Plans should include detailed construction plans showing how the project complies with the agricultural buffer policies outlined in the Agriculture, Conservation and Open Space Element of the General Plan, Section 12.16.170 E of the Municipal Code and the additional buffer criteria in this document. 


\section{SCHEMATIC BUFFER EXAMPIES}

The following schematic examples were developed to demonstrate example buffer construction for development scenarios which involve minimum, moderate, and maximum potential for conflict between urban and agricultural uses. Actual buffer design and construction will vary based upon site specific circumstances.

\section{EXAMPLE MINIMUM BUfFER}

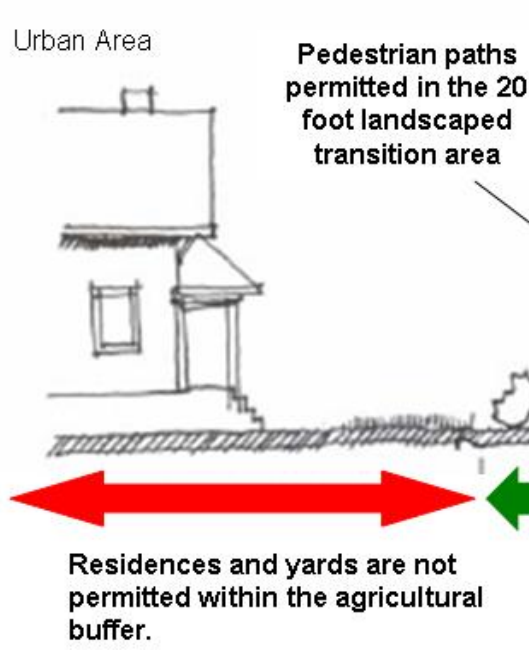

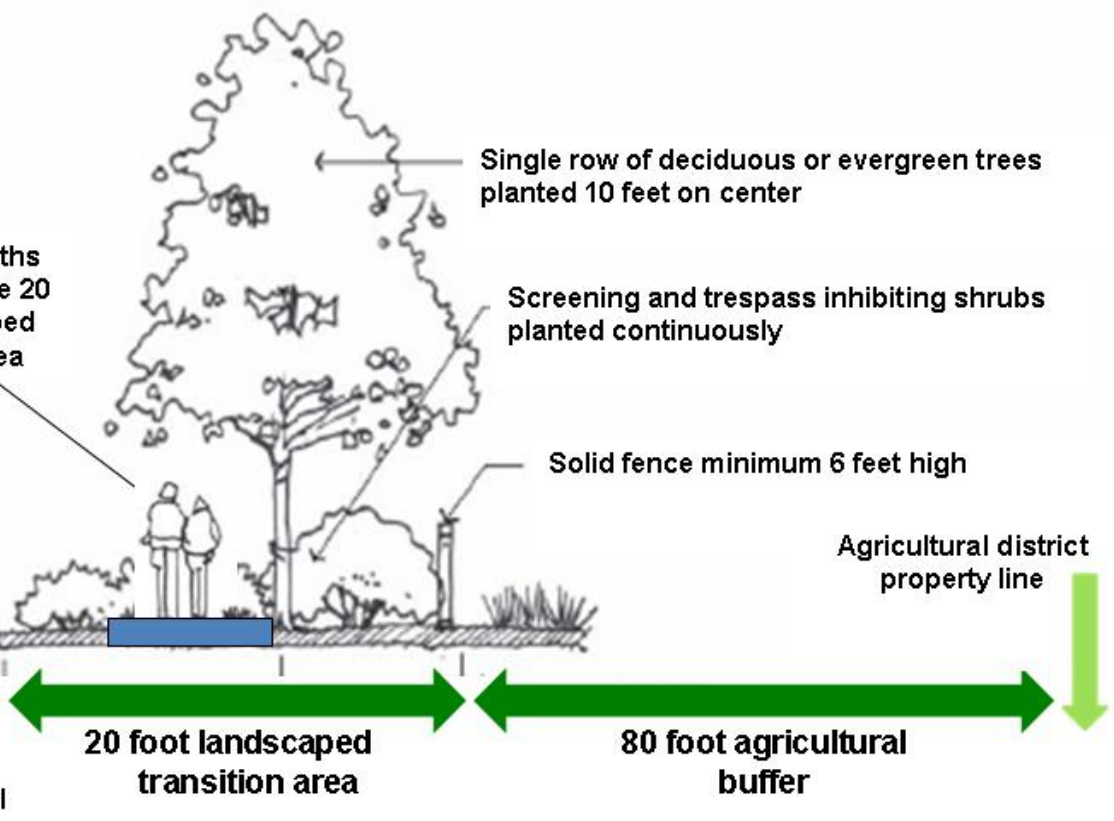

transition area buffer

Applies to sites with minimal risk of conflict. Vegetation should have between $50-75 \%$ porosity. Drought tolerant native species should be used and mature height of trees should be at least 15 feet. Pedestrian paths are permitted within the 20 foot landscaped transition area.

Image Source: City of Abbottsford Canada 


\section{EXAMPLE MODERATE BUfFER}

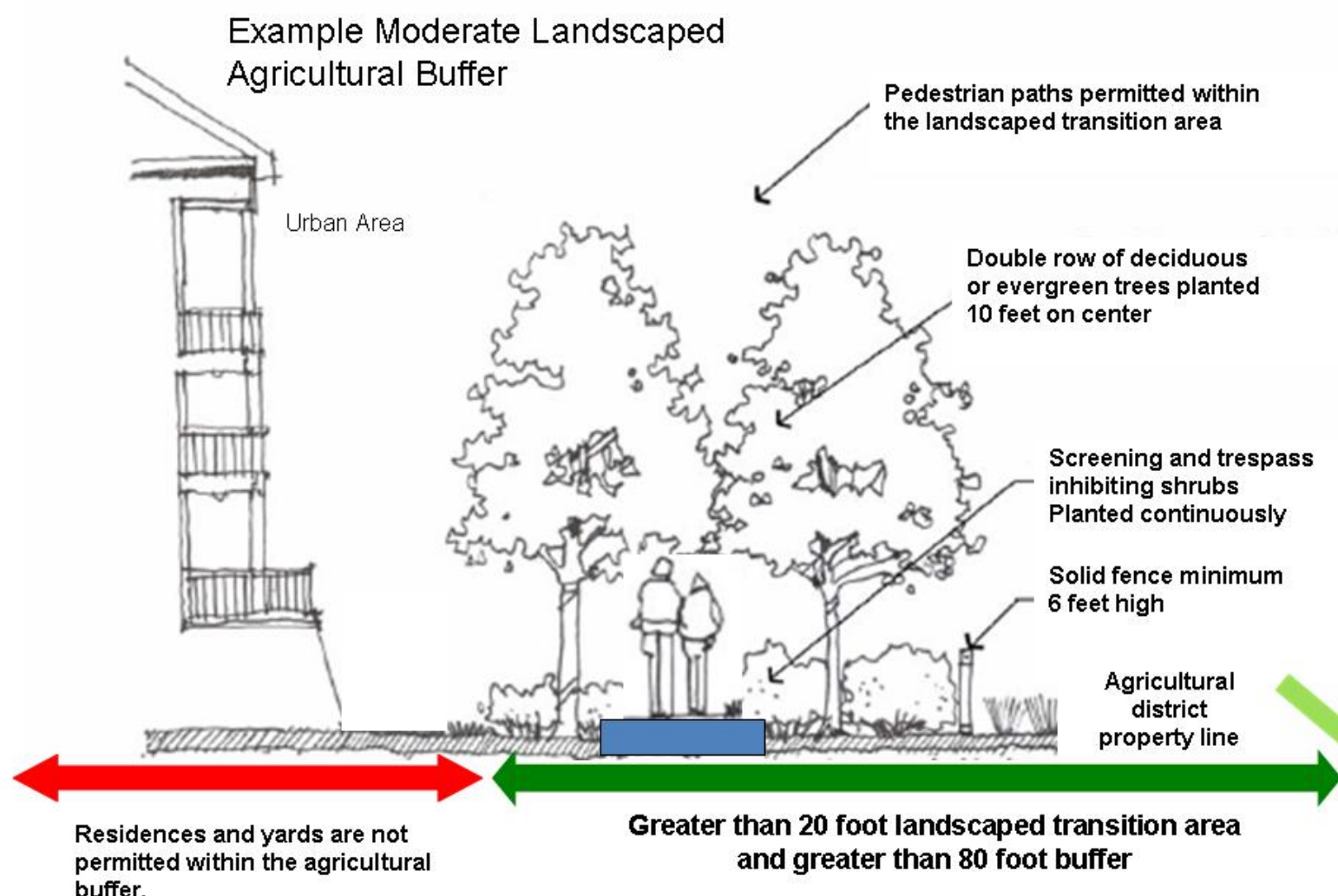

Image Source: City of Abbottsford Canada 
EXAMPLE MAXIMUM BUfFER

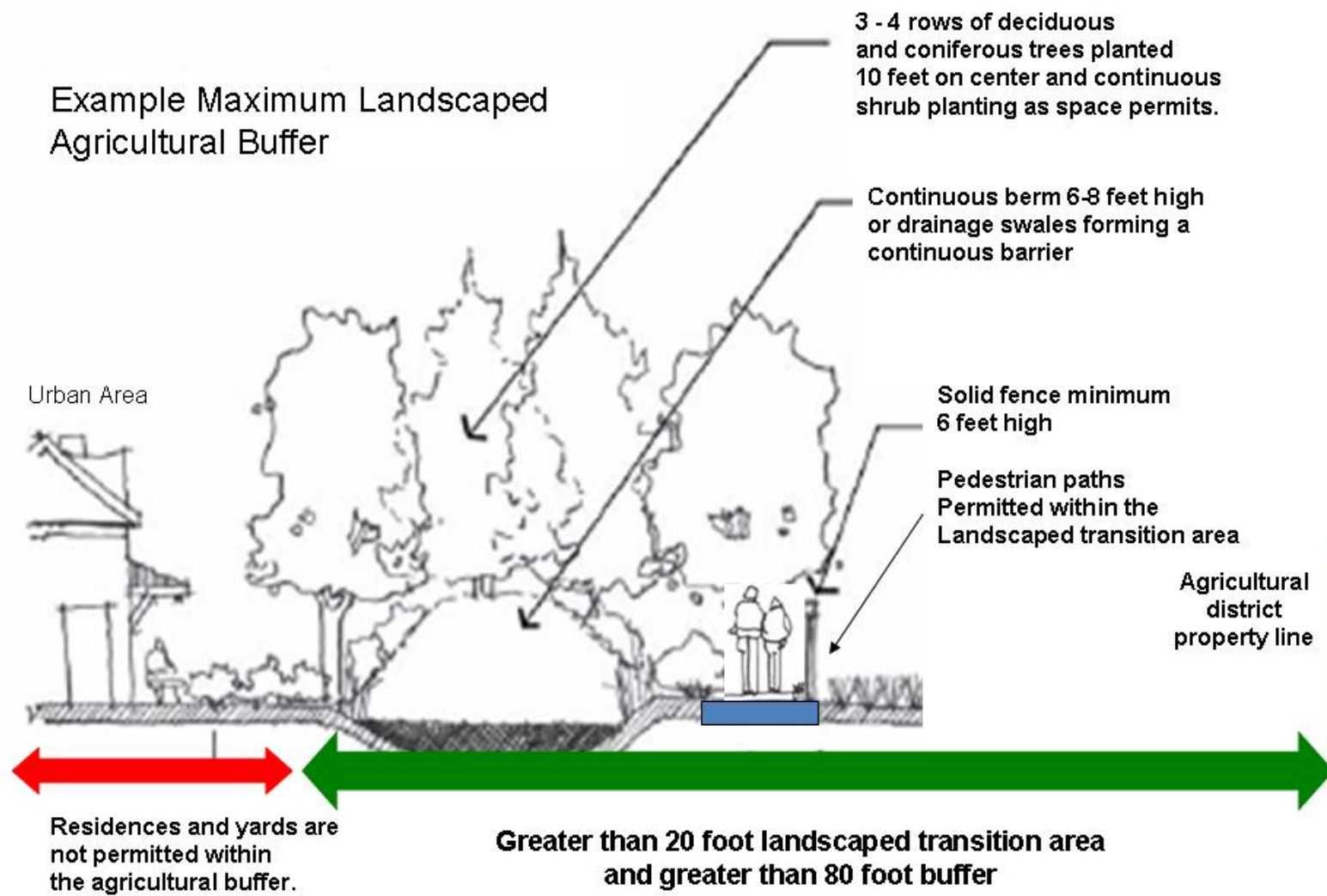

Image Source: City of Abbottsford Canada 


\section{REFERENCES}

Barry, J. W. (1984) Deposition of Chemical and Biological Agents in Conifers. American Chemical Society Symposium Series 238, 117-37.

British Columbia Ministry of Agricultural Lands. (2003). Vegetative Buffers in British Columbia: An Investigation of Existing Buffers and their Effectiveness in Mitigating Conflict. Retrieved October 15, 2008 from: http://www.agf.gov.bc.ca/resmgmt/sf/publications/Urb_Ag_Buffer 03.pdf

British Columbia Ministry of Agricultural Lands. (2008).Guide to Edge Planning - Promoting Compatibility along Urban-Agricultural Edges. Retrieved October 15, 2008 from: http://www.al.gov.bc.ca/resmgmt/sf/publications/8231002_Guide_to_Edge_Planning.pdf

City of Abbotsford British Columbia Canada. (2008). A Landscape Buffering Strategy for the Agricultural-Urban Interface. Retrieved October 7, 2008 from: http://www.abbotsford.ca/AssetFactory.aspx?did=8351

City of Arroyo Grande. (1997). Coordinated Agricultural Support Program (CASP) for the Arroyo Grande Valley. Prepared by Perspective Planning.

City of Arroyo Grande. (2004). General Plan Agriculture, Conservation and Open Space Element.

City of Arroyo Grande. (2008). Municipal Code Chapter 16.12.170 Right to Farm.

City of Davis. (2007a). General Plan Chapter 15 Agriculture, Soils and Minerals.

City of Davis. (2007b). Municipal Code Chapter 40A Right to Farm and Farmland Preservation.

City of Napa. (2006). General Plan Land Use Element.

City of Napa. (2003). Municipal Code Chapter 17.52.040 Agricultural Buffers.

Copprock, Ray and Kreith, Marcia. (1997) California's Future: Maintaining Viable Agriculture at the Urban Edge. University of California Agricultural Issues Center. University of California, Davis.

Department of Natural Resources, Local Government and Planning, Queensland Australia. (1997). Planning Guidelines Separating Agricultural and Residential Land Uses. DNRQ Publication No. 97088. Scientific Publishing. Queensland Australia.

Dorr, G., Woods, N. and Craig, I. (1998) Buffer Zones for Reducing Drift from the Application of Pesticides. Paper No. SEAg 98/008, International Conference on Engineering in Agriculture.

Dosskey, Michael G. (2002) Setting Priorities for Research on Pollution Reduction Functions of Agricultural Buffers. Environmental Management. 30(5), 641 - 650. 
Hammond, S.V. (2002) Can City and Farm Coexist? The Agricultural Buffer Experience in CA. Great Valley Center Agricultural Transactions Program, University of California Cooperative Extension Program. Modesto, CA. Retrieved online April 19, 2008 from: http://66.42.231/publications/agpubs/buffer_study.pdf

Handel, Mary E. (1994) Conflicts and Solutions When Agricultural Land Meets Urban Development. M.S. Thesis, Department of Human and Community Development, University of California, Davis.

Hewitt, A.J. (2001) Drift Filtration by Natural and Artificial Collectors: A Literature Review. Stewart Agricultural Research Services. Macon, MO.

Lowrance, Richard; Dabney, S.; Schultz, R. (2002) Improving Water and Soil Quality $\quad$ with Conservation Buffers. Journal of Soil and Water Conservation, 57(2), 36 - 44

Miller, P.C.H. and Lane, A.G. (1999) Relationship between spray characteristics and drift risk into field boundaries of different structure: Aspects of Applied Biology, Field Margins and Buffer Zones. Ecology, Management and Policy, 54, 45-51.

Nassauer, Joan I. (1989). Agricultural Policy and Aesthetic Objectives. Journal of Soil and Water Conservation. 44(5), 384 - 387

Owens, P.N.; Duzant, J.H.; Deeks, L.K.; Wood, G.A.; Morgan, R.P.; Collins, A.J. (2007) Evaluation of Contrasting Buffer Features Within an Agricultural Landscape for Reducing Sediment and Sediment-Associated Phosphorous Delivery to Surface Waters. Soil Use and Management. 23(1). 165-175

Popov, V.H.; Cornish, P.S.; Sun, H. (2006) Vegetated Biofilters: The Relative Importance of Infiltration and Adsorption in Reducing Loads of Water-Soluble Herbicides in Agricultural Runoff. Agriculture, Ecosystems \& Management. 114(2), 351

Provincial Agricultural Land Commission of British Columbia. (1993). Landscaped Buffer Specifications. Retrieved November 2, 2008 from: http://www.alc.gov.bc.ca/publications/buffer/lbs_main.htm

San Luis Obispo County (2005). Agricultural Buffer Policies and Procedures. Retrieved March 1, 2009 from: http://www.slocounty.ca.gov/AssetFactory.aspx?did=13199

San Luis Obispo County. (2006). County Approved Plant List. Retrieved March 1, 2009 from: http://www.slocounty.ca.gov/AssetFactory.aspx?did=3429

San Luis Obispo County. (2007a). General Plan Agriculture and Open Space Element.

Sloots, K.; Van der Vlies, A.W. (2007) Emission Reduction by Multipurpose Buffer Strips on Arable Fields. Water Science and Technology. 56(1), 81-88

Spillman, J. J. and Woods, N. (1989) cited by Dorr, G., Woods, N. and Craig, I. (1998) Buffer Zones for Reducing Drift from the Application of Pesticides. Paper No. SEAg 98/008, International Conference on Engineering in Agriculture. Perth, Western Australia.

Spray Drift Task Force. (1997). Retrieved March 1, 2009 from: www.agdrift.com 
Stanislaus County. (2007a). General Plan Agriculture Element Appendix A.

Sullivan, William C.; Anderson, Olin M.; and Lovell, Sarah Taylor. (2004) Agricultural Buffers at the Rural-Urban Fringe: An Examination of Approval by Farmers, Residents and Academics in the Midwestern United States. Landscape and Urban Planning, 69(2), 299

Sullivan, William C.; Lovell, Sarah Taylor. (2006) Environmental benefits of conservation buffers in the United States: Evidence, promise, and open questions. Agriculture, Ecosystems and Environment, 112, 249-260

Ventura County. (2006). Agricultural/Urban Buffer Policy. Retrieved March 6, 2009 from: http://portal.countyofventura.org/pls/portal/docs/PAGE/AGCOMMISSIONER/LAND_U SE_PLANNING/APACBUFFERPOLICY_0.PDF

Voller, P. (1999) Growing Trees on Cotton Farms, Rural Industries Research and Development Corporation, Canberra Press. Australia.

Vought, LBM; Pinnay, G.; Fuglsang, A.; Ruffinoni, C. (1995). Structure and Function of Buffer Strips from a Water Quality Perspective in Agricultural Landscapes. Landscape and Urban Planning. 31, 323 - 331.

Zande, J. C., Michielsen, J. M. G. P., Stallinga, H. and de Jong, A. (2004) The Effect of Windbreak Height and Air Assistance on Exposure of Surface Water Via Spray Drift. Proceedings from the British Crop Protection Conference - Pests and Diseases 2004, Brighton, U.K 


\section{AGRI CULTURE, CONSERVATI ON and OPEN SPACE ELEMENT}

\section{Principals:}

- That resources such as prime capability soils are highly productive whether for agricultural purposes, watershed or natural habitat.

- Resources that are irretrievable and/or irreplaceable need to be protected and preserved.

- Individuals and the community have a responsibility to future generations as well as to wildlife to preserve and protect finite natural resources.

- Resources lands contribute to overall public health, safety and welfare beyond provision of basic necessities such as food, fiber and livelihood.

- Land Use and urban development shall be managed and limited to that which can be sustained by the available resources and serviced by the circulation and other infrastructure systems.

\section{AGRICULTURE OBJ ECTI VES and POLICIES:}

\section{Ag1 Avoid and or mitigate loss of prime farmland soils and conserve non-prime Agriculture use and natural resource lands.}

Ag1-1 Designate prime farmland soils that are not predominately committed to nonAgricultural development as Agriculture (Ag) and/or Agriculture Preserve (AgP), whether or not in current agricultural productive use.

Ag1-1.1 Prime Farmland Soils shall include all land, whether a single parcel or contiguous parcels, that if irrigated, qualifies for rating as Class I or Class II in the USDA Natural Resources Conservation Service land use capability classification whether or not the land is actually irrigated, provided that irrigation is feasible. (This definition is derived from the Local Government Reorganization Act of 2000 as reorganized and amended in 2000. Section 56064(a)). Prime farmland soils shall also include farmland of Statewide importance as identified in the USDA, Natural Resources Conservation Services, outlined in the Land Inventory and Monitoring (LIM) Project Soil Survey for San Luis Obispo County, California, Coastal Part, September 1984.

Ag1-1.2 Public facilities are permitted on agricultural and natural resource land when required by health, safety, or welfare of the public.

Ag1-1.3 Either Agriculture or Agriculture Preserve zoning are consistent with the Agriculture classification of the plan.

Ag1-2 Designate as Conservation/Open Space (C/OS) or County Rural Lands all nonprime Ag lands with important natural resource or open space values that the community intends to conserve. 
Ag1-2.1 Areas with a C/OS designation shall be subject to special measures and/or programs designed to conserve natural resources and protect the community from their loss, including measures or programs that may be developed subsequent to adoption of this General Plan Update.

Ag1-3 Support existing programs and develop strategies to retain areas of farmland soils for agricultural use, and other Conservation/Open Space (C/OS) areas in a natural, undeveloped state.

Ag1-3.1 Encourage Williamson Act participation and acquisition of Agricultural Conservation Easements by agricultural landowners. An inventory of parcels under Williamson Act contract and those with easements within the City shall be maintained by the Community Development Department and the status of those contracts/easements reported to the Planning Commission and City Council. The City's objective shall be $100 \%$ of either Williamson Act enrollment of qualified parcels or agricultural conservation easement acquisition. The City's aim shall be to maintain contiguity of $\mathrm{Ag}$ and $\mathrm{C} / \mathrm{OS}$ parcels and avoid fragmentation of areas having prime farmland soils or non-prime Conservation/Open Space designation.

Ag1-3.2 Encourage dedication of conservation easements over parcels having Conservation/Open Space (C/OS) designation. An inventory of conservation easements and similar restrictions within the City shall be maintained by the Community Development Department and reported annually to the Planning Commission and City Council. The City's objective shall be to maintain $100 \%$ of the Conservation/Open Space designation under interim or permanent open space or conservation easements.

Ag1-4 Establish and apply a significance criterion (threshold of significance) for CEQA analysis, as provided by CEQA Guidelines Section 15064.7, that considers loss of prime farmland soils as a significant adverse environmental impact.

Ag1-4.1 Loss of prime farmland soils shall refer to their unavailability for agricultural use. Loss may occur through natural causes or development such as coverage (e.g., paving, construction of buildings, etc.), or conversion to urban/suburban use (including residential yards/gardens and recreational areas). Cessation of agricultural use shall not constitute loss so long as the parcel remains fallow or is allowed to revert to a natural undeveloped state. Site improvements that are intended to support agricultural operations - such as grading, irrigation or drainage facilities, unpaved roads, or farm buildings and structures -- shall not constitute loss so long as the improvements do not substantially diminish the capability of agricultural operations on the parcel or within the area and the improvements are directly related to agricultural production on the site.

Ag1-4.2 Possible mitigation for loss of areas having prime farmland soils may include permanent protection of prime farmland soils at a ratio of $1: 1$ with regard to the acreage of land removed from the capability for agricultural use. Permanent protection may involve, but is not limited to, 
dedication of a perpetual agriculture or conservation easement or other effective mechanism to ensure that the area chosen as mitigation shall not be subject to loss of its prime farmland soils. Suitability of location shall be determined by the City Council. The aim shall be to protect and preserve prime farmland soils primarily within and contiguous to City boundaries, secondly within the Urban Land Use Element area, and thirdly within the larger Arroyo Grande Valley and La Cienega Valley within the Area of Environmental Concern. Other potential mitigation measures for loss of areas having prime farmland soils include payment of in-lieu fees or such other mitigation acceptable to the City Council.

Ag1-4.3 Since prime farmland soils occur naturally and are geographically specific, the only means for mitigation to less than significant is preservation. The City's aim shall be to maintain contiguity of $\mathrm{Ag}$ and C/OS parcels and avoid fragmentation of areas having prime farmland soils. The City shall avoid development of prime farmland soil areas by directing growth potential to more suitable urban locations. Only after the imposition of available mitigation and consideration of alternatives to avoid the proposed action, may the City Council approve development on prime farmland soils subject to overriding considerations as permitted by California Government Code Section 15093.

Ag1-5 Conserve topsoil by encouraging cooperation between property owners, agriculture operators and growers, agencies and organizations that will result in effective soil conservation practices.

Ag1-5.1 Assure that city streets, drainage systems and other infrastructure do not adversely impact agricultural lands and that the roads, drainage and utility systems are properly maintained.

Ag1-5.2 Actively encourage conservation of soil resources.

Ag1-5.2.1 Make available to area farmers, in conjunction with Natural Resource Conservation Service, voluntary guidelines for farming operations on erodible soils.

Ag1-5.3 Minimize flood damage potential to farmland.

Ag1-5.3.1 Assure that urban developments incorporate adequate runoff and drainage detention and flood control.

\section{Ag2 Allocate and conserve ground and surface water resources for agricultural use and minimize potential Fringe Area and urban development that would divert such resources from agriculture.}

Ag2-1 Maintain water resources for production agriculture, both in quality and in quantity, so as to prevent the loss of agriculture due to competition for water with urban development. 
Ag2-1.1 Minimize County Fringe Area and urban development that would adversely affect: (1) water supplies and quality or (2) groundwater recharge capability needed for agricultural use.

Ag2-1.2 Support efforts to provide needed surface and/or ground water resources for agricultural irrigation to those properties zoned Agriculture, Very Low Density and Low Density.

Ag2-2 Identify groundwater recharge areas that are pertinent to agricultural water usage.

Ag2-2.1 For purposes of this policy, 'groundwater recharge area' refers to all areas with sufficient soil permeability or appropriate geologic structure such that surface water penetrates to one or more subterranean aquifers that are currently used or could reasonably be used in the future for agricultural irrigation.

Ag2-2.2 The location and suitability of groundwater recharge areas shall be identified in CEQA analyses and considered with regard to impacts on agricultural land uses.

Ag2-3 Ensure that urban land use and Residential Rural or Suburban development projects result in no net decrease in groundwater recharge and no adverse effect on agricultural water supplies.

Ag2-3.1 Require mitigation measures that result in no net decrease in groundwater recharge.

Ag2-4 Detention, retention and recharge basins shall be designed as open space and habitat resources in addition to flood control and other functions associated with a development. Their extent and engineering shall permit establishment of vegetative growth and utilization for passive recreation or compatible agricultural uses. The design of such Facilities shall include specific operation and maintenance programs that ensure that the capacity is not reduced.

Ag2-5 Encourage water conservation by both agricultural and urban water users.

Ag2-5.1 Require water-conserving design in urban development proposals.

Ag2-5.2 Distribute irrigation standards for urban area agricultural uses.

\section{Ag3 Current acreage of agricultural uses within Arroyo Grande's Area of Environmental Concern shall be maintained.}

Ag3-1 Designate all lands currently in agricultural use, and vacant lands having been in agricultural use for at least six (6) months within the past ten (10) years, as Agriculture (Ag) unless otherwise classified and partially developed for nonAgricultural uses.

Ag3-1.1 Agricultural use shall include grazing by domesticated animals (e.g. horses, cattle, sheep, goats, etc) or other animals (e.g. buffalo, ostrich, deer, etc.) managed for commercial or conservation purposes; tending 
of animals (e.g. chickens, rabbits, etc.) for commercial products (e.g., eggs, meat, fur) or for conservation purposes (e.g., wildlife refuge); cultivation of food crops intended for human or animal consumption, including products requiring substantial processing after harvest; cultivation of flowers, trees or ornamental flora, including landscaping materials; active management of orchards or vineyards; or any other activity where the soil and climate provide an essential component of commercial productivity.

Ag3-1.2 Commercial value and significance with regard to agricultural use shall refer to the purpose of the activity rather than to any particular economic threshold. The criterion is whether the activity is pursued with the intent to sell agricultural products, directly or indirectly and whether profitable or not. Activity pursued for personal consumption or pleasure (e.g., keeping a horse for family riding, a goat for household milk, or a small vineyard for home vinting) does not qualify as an agricultural use.

Ag3-1.3 Agricultural land shall encompass parcels with agricultural uses and one or more residential structures and/or outbuildings designed to shelter or contain animals or store agricultural products or equipment and supplies.

Ag3-1.4 Parcels with no agricultural uses, of a primarily residential nature, shall be considered residential. Parcels with no agricultural uses, which contain uses related to and supportive of agricultural operations, shall be considered agricultural.

Ag3-1.5 Vacant or undeveloped agricultural land shall refer to fallow cropland, grazing land or land supporting other agricultural uses as identified in AG3-1.1, that is not in productive use at the time of any designation action or re-designation request.

Ag3-2 Outside the City limits and within Arroyo Grande's Area of Environmental Concern, designate those lands identified in San Luis Obispo County's General Plan as Agriculture, which are currently in agricultural use or have been in agricultural use for at least six (6) months within the past ten (10) years, as Agriculture (Ag).

Ag3-2.1 County designation shall be as determined as of December 15, 1998, the date of adoption by the Board of Supervisors, of the County's Agriculture \& Open Space Element.

Ag3-2.2 Should landowners of parcels in this area request consideration for inclusion within the City's Sphere of Influence and/or annexation to the City of Arroyo Grande, the request shall be evaluated based on the City's criteria for Agriculture designation and zoning, and be subject to all policies and regulations pertaining to that use.

Ag3-3 Agricultural land shall be considered as two sub-types: Prime and non-prime. Because of soil and slope conditions, and non-expandable nature of these areas, prime Agriculture areas shall have the highest priority for protection from conversion to urban uses. 
Ag3-3.1 Prime Agriculture shall comprise what are commonly referred to as "bottom lands" within the Arroyo Grande Valley, Huasna Valley, Cienega Valley and Los Berros Valley. These are typically flat, irrigated, and in intensive crop production.

Ag3-3.2 Non-prime areas shall comprise what are commonly referred to as "grass lands" on hillsides and sloped areas generally southeast, east and north of the urban area. These are typically non-irrigated and support grazing or dry-land crops.

Ag3-4 Encourage the expansion of agricultural land uses.

Ag3-4.1 Encourage requests for re-classification of lands in Residential Rural and Residential Suburban and/or Urban land use districts to the Agriculture district.

Ag3-5 All Ag-designated lands shall be considered 'Agricultural Preserve' for Land Conservation Act (Williamson Act) purposes and eligible to enter into Williamson Act contracts to the extent that statutory qualifications are satisfied. The City shall encourage agricultural conservation easements for lands that are not eligible for Williamson Act contracts.

Ag3-5.1 Promote Williamson Act contracts, or agricultural conservation easements, on Ag-designated properties within the City limits and in the City's Area of Environmental Concern. The City's aim shall be $100 \%$ participation of qualified Ag-designated properties that are otherwise not protected in perpetuity.

Ag3-5.2 Encourage the County to support participation in the Williamson Act program by Ag-designated properties within the Area of Environmental Concern under jurisdiction of the County. The City's aim shall be $100 \%$ participation of qualified Ag-designated properties that are otherwise not protected in perpetuity.

Ag3-6 Encourage lot mergers and consolidations, within the Ag district, and among properties seeking inclusion into the Ag district, or meet minimum parcel size requirements for Williamson Act participation and City standards for Agriculture uses, and encourage joint participation in linked agricultural conservation easements.

Ag3-6.1 Establish incentives for lot mergers and consolidations. The City's aim shall be $100 \%$ of Ag-designated properties to be qualified for Williamson Act participation and compliant with City standards, or subject to agricultural conservation easements.

Ag3-7 Where lot mergers and consolidations are impractical, encourage the establishment and maintenance of small-scale agricultural uses, specialty crops, and specialized animal facilities.

Ag3-7.1 Discourage rural residences as the primary use on existing small $\mathrm{Ag}$ designated parcels. 
Ag3-7.2 Advise owners of legally non-conforming Ag parcels that City policy promotes continued agricultural use including specialty crops and rightto-farm adjoining Ag properties.

Ag3-8 Encourage the establishment and succession of agricultural usage.

Ag3-8.1 Cooperate with the County Agricultural Commissioner and Farm Advisors to distribute information encouraging establishment of agricultural uses and conversion to higher value crops to preserve Agriculture and conserve Conservation/Open Space lands.

Ag3-9 Discourage subdivision of Ag designated property.

Ag3-9.1 The minimum parcel size for new land division of Ag designated parcels that are irrigated shall be 20 acres.

Ag3-9.2 The minimum parcel size for new land division of Ag designated parcels that are non-irrigated shall be 40 acres.

Ag3-10 Where land division of an Ag designated property is proposed, the resulting parcels shall be designed to ensure the long-term protection of agricultural resources.

Ag3-10.1 Refer proposed divisions of Agriculture lands to the County Agricultural Commissioner for review and advisory comment as to whether the proposed parcels would be sustainable as agricultural parcels.

Ag3-10.2 Require that Ag parcels meet Williamson Act eligibility standards and enter into Williamson Act contracts if not otherwise protected in perpetuity.

Ag3-10.3 Require that divisions of $\mathrm{Ag}$ designated parcels include covenants, conditions and restrictions (CC\&Rs) notifying subsequent owners that land is an Agricultural reserve and that the City supports its 'Right-toFarm' Ordinance.

Ag3-10.4 Restrict the building sites of a subdivided Ag parcel to no more than 1 acre.

Ag3-10.5 Accessory buildings or structures shall be sited to minimize disruption of agricultural operations, avoid conversions of productive farmland, and take maximum advantage of existing infrastructure.

Ag3-10.6 Maintain existing irrigation infrastructure.

Ag3-11 Allow residential density of no more than two primary dwelling units on each legal parcel of 20 acres or larger within the Ag category. Accessory units for farmworker housing at a higher density may be allowed on parcels greater than 20 acres subject to obtaining a conditional use permit. Allow no more than one primary dwelling unit on each parcel of less than 20 acres; exceptions may be allowed for farmworker housing located on non-prime Agriculture designated lands subject to obtaining a conditional use permit. 
Ag3-12 Except as provided below, permit only Ag-related uses in areas designated Agriculture (Ag).

Ag3-12.1 Ag-related shall mean activities and structures associated with the growing and/or production of agricultural products for income.

Ag3-12.2 Incidental activities (such as roadside stands or bed-and-breakfast/farm stay accommodations) may be permitted, so long as those activities are related to the primary use, are clearly secondary to agricultural use, and that all building sites in the aggregate compose less than 1 acre of conforming (or less than $10 \%$ of the non-conforming) parcel size and are situated such that they do not impinge upon the agricultural activities of the parcel and/or the Ag district.

Ag3-13 Discourage conversion of land within Ag designated areas to non-Agriculture uses.

Ag3-13.1 Cooperate with the County, special districts, and agricultural organizations/agencies to establish urban service and urban reserve lines that will protect agricultural land and stabilize agricultural uses within the Area of Environmental Concern.

Ag3-14 Consider re-classification of an Ag parcel (or contiguous set of parcels), only if and when the parcel or set of such parcels is less than minimum size (e.g. legally nonconforming as to area) and is isolated from other agricultural uses.

Ag3-14.1 "Isolated" shall refer to a parcel or set of parcels being predominately separated from other nearby Agriculture areas, or predominately surrounded by existing non-agricultural uses, such that it lacks contiguity with or connection to other areas of existing or potential agricultural use.

Ag3-14.2 In cases considered for conversion, the parcel(s) shall be adequately served by appropriate infrastructure and any development application shall be subject to environmental analysis as referenced in AOSCE Policy Ag1-4.

Ag3-15 Re-designation requests shall avoid leapfrogging of parcels in agricultural use that would result in other $\mathrm{Ag}$ parcels being widowed, including uses within County jurisdiction as well as uses within City.

\section{Ag4 Support continued economic viability of agriculture as a specialized site-specific industry.}

Ag4-1 Support increased productivity and enhancement of markets and/or Ag uses, such as vineyards, in appropriate areas, especially in locations that would retain Ag. Lands and/or improve or reestablish agricultural productivity.

Ag4-1.1 Continue support of the Farmers Market in Arroyo Grande on a regular basis in one or more appropriate locations.

Ag4-2 Support the development of new techniques and new practices in agricultural production. 
Ag4-2.1 Favorably consider proposals for agricultural uses and practices that are compatible with surrounding uses.

Ag4-2.2 Minimize the burden to agricultural operators of any review and permitting requirements by the City.

Ag4-2.3 Affirm the City's Right to Farm Ordinance and its extension to new techniques and practices.

Ag4-3 Provide incentives for landowners to maintain land in productive agricultural uses.

Ag4-3.1 Encourage the establishment of small-scale agricultural uses, specialty crops, and specialized livestock facilities other than processing on existing small land parcels in the Ag category.

Ag4-4 Allow incidental visitor-serving and incidental retail use and facilities in $\mathrm{Ag}$ designated areas that are beneficial to the agricultural industry and are compatible with long-term agricultural use of the land. Such uses shall be clearly incidental and secondary to the primary agricultural uses of the site, and meet the criteria of Ag3-12.2.

Ag4-4.1 Visitor-serving uses may include tourism facilities such as bed-andbreakfast/farm stay lodging or food-serving establishments. Such uses shall be of a small-scale nature with discrete signage.

Ag4-4.2 Incidental retail uses may involve on-site, area-specific or productspecific promotion and marketing of agricultural products, such as wine tasting at a vineyard. Such uses shall be of a small-scale nature with discrete signage.

Ag4-4.3 Locate visitor-serving and incidental retail uses on the least productive agricultural lands unless there are no other feasible locations

Ag4-5 Promote the establishment of service commercial type uses related to the support of local agricultural production outside Ag areas.

Ag4-5.1 Locate Ag related service commercial uses in commercial or industrial districts with convenient access to areas of agricultural production. Service commercial type uses may include, but are not limited to, farm equipment rental and repair services, veterinary services, and bulk supplies.

Ag4-6 Promote the establishment of compatible industrial facilities that support local agricultural production, processing, packing, and related industries.

Ag4-6.1 Compatible industrial facilities include facilities that are fully enclosed and do not generate dust, odors or other emissions that may adversely affect residents or workers. Such facilities may include small-scale wineries, breweries, ice manufacturing, and other facilities as evaluated on a case-by-case basis. 
Ag4-6.2 Incompatible agricultural facilities of an industrial nature may include poultry operations, hog farms, feed lots, feed and grain mills, meatpacking plants, food processing plants, produce packing sheds, and certain types of transportation facilities for agricultural products and supplies, as evaluated on a case-by-case basis.

Ag4-6.3 Locate agriculturally related industrial facility uses in commercial or industrial districts with convenient access to areas of agricultural production.

\section{Ag5 Promote coexistence of agricultural and urban land uses.}

Ag5-1 Affirm the Right-to-Farm Ordinance.

Ag5-1.1 Extend Right-to-Farm provisions to new areas that are adjoining lands approved for addition to the Agriculture district.

Ag5-2 Establish criteria for buffers between Agriculture land use designations and nonAgriculture land use designations.

Ag5-2.1 Buffers shall be established on all parcels proposed for non-agricultural development adjacent to agricultural uses, when the property is exposed to agricultural operations.

Ag5-2.2 No portion of any new residential structure within a non-Agricultural land use designation shall be located closer than 100 feet from the site of agricultural operations within an Agricultural land designation. Greater distances may be required based upon site-specific circumstances, to include consideration of established or existing farming operations or practices.

Ag5-2.3 The buffer area shall be noticed and/or fenced and landscaped in such manner to discourage human and domestic animal movement between the urban and agricultural areas and to screen urban uses from dust and wind-borne materials.

Ag5-2.4 The buffer area shall contain a minimum 20 feet depth of landscaping. Plantings shall be sufficiently dense and mature to provide aerosol protection within the first year of establishment. Greater landscaping depth may be required based upon site-specific circumstances, to include consideration of established or existing farming operations or practices.

Ag5-2.5 Buffer standards associated with non-residential structures and roadways shall account for the type of use, building orientation and building and roadways design.

Ag5-3 Land use conversions shall not adversely affect existing or potential agriculture production on adjacent lands designated Ag.

Ag5-4 Design special assessments that are equitable with regard to benefits, such that agricultural landowners are not disproportionately assessed for services that accrue 
to urban residents more than farmers or ranchers. Examples of such urban services include fire protection, park and recreation services and neighborhood street lighting.

Ag5-5 Minimize trespassing into agricultural areas, through signage, access restrictions, fines and other available means

Ag5-6 Establish a grievance or arbitration committee to mediate land use disputes between farmers and adjoining non-farm residents.

\section{Ag 6 Agriculture classification shall include minimum development standards:}

Ag6-1 Ag zoning classifications shall prescribe minimum parcel sizes of 20-acres for cultivated, irrigated and/or prime agricultural land, and 40 acres for non-cultivated, non-irrigated and/or non-prime agricultural lands.

Ag6-2 Ag Zoning classifications shall allow 1 dwelling unit per 10 acres and accessory structures provided all buildings comply with Ag 3-10.4, Ag 3-10.5 and Ag 3-11.

\section{CONSERVATI ON and OPEN SPACE OBJ ECTI VES and POLICI ES}

\section{C/ OS1 Protect visually accessible scenic resources.}

C/OS1-1 Identify and protect scenic resources and view sheds associated with them

C/OS1-1.1 For purposes of this policy, a 'scenic resource' may refer to agricultural land, open spaces, hillsides, ridgelines, canyons, valleys, landmark trees, woodlands, wetlands, streambeds and banks, as well as aspects of the built environment that are of a historic nature, of unique to the City, or contribute to the rural, small town character of the City.

C/OS1-1.2 For purposes of this policy, a 'view shed' refers to locations from which a scenic resource is visible. Such locations may be privately owned but generally accessible to the public. Public vantage points, such as travel paths (roadways, trails) or public facilities (schools, parks, etc) are especially important view sheds to maintain.

C/OS1-1.3 Establish designated scenic corridors along public roads and highways that have unique or outstanding scenic attributes, such as views of prominent hills, mountains or canyons; views of stands of trees or wildflowers; views of the Pacific Ocean or streams.

C/OS1-1.4 Locate structures, roads and grading on portions of a site so as to minimize visual impact. Locate developments below prominent ridgelines and hilltops such that they are not silhouetted against the sky.

C/OS1-1.5 Use natural landforms and vegetation to screen development.

C/OS1-1.6 Minimize signs, especially freestanding signs. Secure removal of nonconforming signs within scenic corridors as part of discretionary development projects. 
C/OS 1-1.7 Prohibit off-premise advertising signs in all Agriculture, Conservation/Open Space, and Residential designated areas of the City and planning area.

C/OS1-2 Identify unique landforms and designate them as Conservation/Open Space $(\mathrm{C} / \mathrm{OS})$ to require or encourage their protection, conservation and/or preservation.

\section{C/OS2 Safeguard important environmental and sensitive biological resources contributing to healthy, functioning ecosystem.}

C/OS2-1 Designate all streams and riparian corridors as Conservation/Open Space (C/OS).

C/OS2-1.1 'Streams' and 'riparian corridors' shall include buffer area corresponding at least to natural vegetation and/or creek bank.

C/OS2-1.2 Preserve stream and riparian corridors in their natural state except that periodic flood control maintenance consistent with State and Federal permits shall be allowed.

C/OS2-1.3 Where feasible, maintain a grading and building setback of 25 feet from the top of stream bank. Locate buildings and structures outside the setback. Except in urban areas where existing development exists to the contrary, prevent removal of riparian vegetation within 25 feet of the top of stream bank.

C/OS2-1.4 Creekside trails may be designed within stream and riparian corridors and building setback providing design and grading are consistent with State and Federal permits and are sensitive to natural vegetation and include landscape mitigation.

C/OS2-2 Identify unique or sensitive habitat areas and designate them Conservation/Open Space (C/OS) overlay.

C/OS2-2.1 Designate wetlands as Conservation/Open Space.

C/OS2-3 Identify and designate Conservation/Open Space (C/OS) other public or private properties containing scenic resources or public vistas of scenic importance.

C/OS2-4 Identify and protect wildlife corridors that link habitat areas as Conservation/Open Space (C/OS).

C/OS2-4.1 Encourage agricultural landowners and managers of Conservation/Open Space to adopt range and farmland management practices that will not interfere with the movement of wildlife through their properties.

C/OS2-4.2 Public or private developments that require discretionary permit or propose a land division, shall avoid disturbance of significant wildlife corridors, and/or wetlands identified by City or County environmental studies. 
C/OS2-4.3 When evaluating discretionary proposals as part of the CEQA process, require mitigation measures that would re-establish damaged or disturbed corridors and provide for long-term viability.

\section{C/ OS3 Plan for a well-maintained system of footpaths and non-vehicular trails that provide access to areas of non-urban environment.}

C/OS3-1 In Residential Rural and Suburban County areas and developments in the unincorporated portions of the planning area, and in all urban land use developments adjoining possible trail alignments within the City, provide for equestrian, hiking and biking trails, particularly those providing access to schools, parks and community facility activity areas.

C/OS3-2 Access trails shall not conflict with Agriculture use or significantly disturb environmentally sensitive resources.

\section{C/ OS4 Preserve historic and cultural resources of public interest that reflect the legacy of earlier human settlement.}

C/OS4-1 Identify historic and cultural resources that should be protected as C/OS combining designations.

C/OS4-2 Avoid disturbance of archaeological and culturally sensitive sites.

C/OS4-3 Encourage acquisition of significant designated C/OS sites by public agencies, historical or conservation organizations for preservation and restoration where feasible, or require private conservation by adaptive reuse if not.

C/OS4-4 Protect the character of significant historical features and settings by C/OS designation. Maintain a listing of historic and cultural resources.

\section{C/ OS5 Conservation/ Open Space classification shall include minimum development standards:}

C/OS5-1 C/OS zoning classifications shall prescribe minimum parcel sizes of 5 acres, 10 acres or 20 acres (e.

+g. C/OS5) as determined appropriate by the City based on existing parcel size or sensitivity to development.

C/OS5-2 C/OS zoning classifications shall allow 1 dwelling unit per parcel provided all buildings and related grading and infrastructure complies with Ag3-10.4 and Ag3-10.5 related to conservation of natural resources.

C/OS6 The City of Arroyo Grande shall manage land use and limit its urban development potential to that which can be sustained by the available water resources and serviced by circulation and other infrastructure.

C/OS6-1 Water resources currently available include 1200 acre-feet annually of groundwater extraction from Arroyo Grande Basin, 2290-acre feet annual entitlement from Lopez Lake and 100 acre feet per year from the Pismo formation. The $3590 \mathrm{ac}$. ft/year minimum supply during drought conditions is 
estimated as capable of supporting a City of 20,000 residents (at $160 \mathrm{gpd}$ per capita average consumption).

C/OS6-1.1 The City shall consider more efficient water utilization and conservation measures in subsequent Water Management Master Plan amendments to reduce average annual per capita consumption including the Best Management Practices already identified. The City will monitor water use by type and density of land use including agriculture, residential, office and commercial. The City will reflect any changes to regional water resources available to the City by periodic amendment to the City's Water Master Plan.

C/OS6-2 Residential Rural and Residential Suburban uses in the unincorporated Arroyo Grande Fringe Area utilize individual wells and septic systems located in the Arroyo Grande Creek watershed which cumulatively impact water quantity and quality available for agriculture and urban uses.

\section{I mplementation Measures}

Ag/C/OS.1 Designate all deed-restricted open space, identified as part of a Planned Development entitlement or Specific Plan, as Permanent Open Space (P/OS).

$\mathrm{Ag} / \mathrm{C} / \mathrm{OS} .2$ Re-designate all open space, which becomes deed-restricted through voluntary dedication or in conjunction with development activities, as Permanent Open Space.

$\mathrm{Ag} / \mathrm{C} / \mathrm{OS} .3$ Maintain an inventory of $\mathrm{P} / \mathrm{OS}$ and $\mathrm{C} / \mathrm{OS}$ designated open space, along with specific restrictions.

$\mathrm{Ag} / \mathrm{C} / \mathrm{OS} .4$ Encourage private landowners to voluntarily protect and maintain open space resources on their properties.

$\mathrm{Ag} / \mathrm{C} / \mathrm{OS} .5$ Encourage and support efforts to protect lands containing open space resources by state and federal agencies, the County, special districts, and non-profit and conservation organizations.

Ag/C/OS.6 Encourage application of Williamson Act programs and Conservation/Open Space easements to all eligible private properties.

Ag/C/OS.7 Coordinate efforts to acquire significant conservation and Permanent Open Space lands with other public agencies and conservation organizations.

Ag/C/OS.8 Actively seek available grants and aid programs from state and federal agencies and private foundations to fund acquisition and maintenance of Open Space and Agriculture lands.

Ag/C/OS.9 Actively seek contributions of land, development rights, easements, and money from individuals and corporations, both for preservation of open space and recreation land in general and for acquisition of specific priority properties. Consider using San Luis Obispo Parks, Open Space and Trails Foundation as a vehicle for donations and gifts. 
$\mathrm{Ag} / \mathrm{C} / \mathrm{OS} .10$ Encourage the use of cluster land divisions and cluster development that will locate development on the least environmentally sensitive portions of properties where the balance of land is preserved in Permanent Open Space.

Ag/C/OS.11 Where a landowner proposes a land division, the proposed parcels shall maintain or enhance the long-term protection of Open Space.

Ag/C/OS.12 Park sites and recreation areas shall protect scenic and environmentally sensitive resources, and shall not conflict with Agriculture uses.

Ag/C/OS.13 Develop a Strategic Action Plan for Agriculture and Open Space preservation (prioritize locations, identify actions, responsible entities, funding, timing, and performance monitoring).

Ag/C/OS.14 Consider an impact mitigation fee program as adjunct to, or in lieu of, direct dedication of off-site Agriculture or conservation easement.

$\mathrm{Ag} / \mathrm{C} / \mathrm{OS} .15$ Establish a fund for the purchase of Permanent or Conservation/Open Space easements and investigate all available revenue sources for funding, including:

a. grants/loans from State or Federal agencies;

b. grants/loans from private foundations/organizations;

c. citywide tax or participation in countywide tax; and,

e. mitigation fees

$\mathrm{Ag} / \mathrm{C} / \mathrm{OS} .16$ Assist in developing a public education and outreach program relative to conservation easements (personal advantages) and permitted uses and activities on easement areas.

Ag/C/OS.17 Collaborate with the County, SLOCOG and/or adjacent jurisdictions (e.g., Cities of Pismo Beach, Grover Beach and Oceano CSD) to develop a "model agricultural conservation easement" document to be used as the basis for negotiation with individual property owners.

$\mathrm{Ag} / \mathrm{C} / \mathrm{OS} .18$ Establish a program that provides the City with a low cost option or contractual arrangements with agricultural landowners to acquire "right of first refusal" with regard to acquisition when the owner becomes interested in selling a property.

Ag/C/OS.19 Establish or contract with an existing Land Trust to administer ownership of Ag parcels and manage agricultural activities.

Ag/C/OS.20 The City should initiate a program for riparian corridor acquisition, wetland, restoration and storm Water Pollution Prevention programs.

Ag/C/OS.21 Support the establishment of a local funding mechanism, as identified by City Council, which allocates funds toward the voluntary purchase of agricultural, conservation, and open space easements. 


\subsubsection{Right to farm provisions.}

A. Purpose and Intent. It is the purpose of this section to:

1. Protect agricultural land uses and designations identified on the general plan and zoning map from conflicts with nonagricultural land uses that may result in financial hardship to agricultural operators or the termination of their operation;

2. Promote a good neighbor policy between agriculturalists and residents by advising purchasers and residents of property adjacent to or near agricultural operations of the inherent potential problems associated with such purchase or residence including, but not limited to, the sounds, odors, dust and chemicals that may accompany agricultural operations so that such purchasers and residents will understand the inconveniences that accompany living side by side to agriculture and be prepared to accept such problems as the natural result of living in or near agricultural areas.

It is the intent of the city council that no agricultural activity, operation or facility, or appurtenances thereof, conducted or maintained for commercial purposes, and in a manner consistent with proper and accepted customs and standards, as established and followed by similar agricultural operations in the same locality, shall be or become a nuisance, private or public, due to any changed condition in or about the locality on nonagricultural land after the same has been in operation for more than three years if it was not a nuisance at the time it began.

B. Applicability. "Agricultural land" means land use categories identified in the land use element, land zoned exclusively for agricultural use (as defined in Section 16.04.070), or land in agricultural production.

C. Policy. The city council finds that it is in the public's interest to preserve and protect agricultural land and operations within the city and to specifically protect these lands for exclusive agricultural use. The city council also finds that residential development adjacent to agricultural land and operations often leads to restrictions on farm operations to the detriment of the adjacent agricultural uses and economic viability of the city's agricultural industry as a whole. The purposes of this section, therefore, are to promote the general health, safety and welfare of the city; to preserve and protect for exclusive agricultural use those lands zoned for agricultural use; to support and encourage continued agricultural operations in the city; and to provide public information regarding this section which outlines the inherent potential problems associated with living, purchasing and/or residing adjacent to agricultural lands. These potential problems include, but are not limited to the sounds, odors, dust and chemicals that may accompany agricultural operations.

D. Public Information. Information concerning this section shall be made available by the city planning department, including the following notice:

The City of Arroyo Grande is an agricultural City with many areas zoned for and/or utilized for agricultural operations. The presence of farms yields significant aesthetic and economic benefits to the residents of the City. Thus, the City's agriculture must be protected, including areas where it is near residential development, and the City of Arroyo Grande has enacted an ordinance which provides that properly conducted agricultural operations will not be deemed a nuisance.

Accordingly, if the property you own, rent, or lease is located close to agricultural lands or operations, you may be subject to inconvenience or discomfort from the following Cultivation and tilling of the soil; burning of agricultural waste products; lawful and proper use of agricultural chemicals including, but not limited to, the application of pesticides and fertilizers; and production, irrigation, pruning, growing, harvesting and processing of any agricultural commodity, including horticulture, timber, apiculture, the raising of livestock, fish, poultry and commercial practices performed as incident to or in conjunction with such agricultural operation, including preparation for market, delivery to storage or market, or to carriers or transportation to market. These operations may generate dust, smoke, noise and odor.

The city is required to make information on section and its provisions available to the public upon request. 


\section{E. Agricultural Buffer.}

1. In conjunction with general plan policies outlined in the agriculture, conservation and open space element, and specifically Objective Ag5, the city has determined that the use of property for agricultural operations is a high priority. To minimize potential conflicts between agricultural and nonagricultural land uses, including the protection of public health, the reduction of noise and odor, and the reduction of risk to farm operations from domestic animal predation, crop theft and damage and complaints from neighboring urban dwellers, all new development adjacent to any designated agricultural district shall be required to provide an agricultural buffer. "Development" as used in this section, means subdivision of land, use permits and building permits for new residential units.

2. The buffer area shall be a minimum of one hundred (100) feet, measured from the edge of the designated agricultural district. Optimally, to achieve a maximum separation, a buffer wider than one hundred (100) feet is encouraged and may be required if it is determined through environmental review under CEQA and/or recommended by the San Luis Obispo County Agricultural Commissioner. A decreased buffer distance may be allowed if it can be demonstrated that a physical buffer exists (e.g. Arroyo Grande Creek) that is adequate and approved by the San Luis Obispo County Agricultural Commissioner.

3. The minimum one hundred (100) foot agricultural buffer area shall be comprised of two (2) components: a twenty (20) foot wide agricultural landscaped transition area contiguous to an eighty (80) foot wide agricultural buffer adjacent to the designated agricultural district. The twenty (20) foot transition area may include pedestrian access. The combined one hundred (100) foot agricultural buffer shall not qualify as farmland mitigation as required by Section 16.12.170.F.

4. The following shall be permitted in the one hundred (100) foot agricultural buffer: native plants, tree or hedge rows, roads, drainage channels, storm retention ponds, natural areas such as creeks or drainage swales, utility corridors, storage, and any use, including agricultural or limited commercial uses, determined by the planning commission to be consistent with the use of the property as an agricultural buffer. No new residential use shall be permitted within the buffer area unless it is determined there would be no other economically viable use of the property. Restoration of a damaged residence within the buffer area may be pursued in accordance with Section 16.48.110.

5. The one hundred (100) foot agricultural buffer shall be established by the developer pursuant to a plan approved by the community development director and the parks, recreation and facilities director. The plan shall include provisions for the use of integrated weed and pest management techniques and soil erosion control. An agreement in the form approved by the city attorney shall be recorded, which shall include the requirements of this section. 


\section{Appendix C}

\section{City of Davis, CA}

Agriculture, Soils and Minerals Element of the General Plan

Section 40A of the Municipal Code - Right to Farm and Farmland Protection Provisions 


\section{Chapter 15. Agriculture, Soils and Minerals}

\section{BACKGROUND}

\section{Agricultural Resources}

Much of the area surrounding Davis is used for agriculture, and agriculture is the most significant industry in the region. The Davis area has a temperate climate with sunny skies, cooling summer winds, and light rainfall during moderate winters, which is ideal for agriculture. There is adequate rainfall for crop growth during seven months of the year; irrigation is required for continued growth during the rest of the year. Approximately 275 days of the year have a minimum temperature of 32 degrees, which constitutes the growing season.

Figure 33 shows the agricultural soil classifications in the Davis Planning Area. "Prime agricultural land" in the Planning Area has been classified in three separate classification systems: the U.S. Natural Resources Conservation Service Land Capability Class System of I through VII; the State Department of Conservation's Important Farmland Inventory System; and the Cortese-Knox Local Governmental Reorganization Act of 1985 Criteria. The Natural Resources Conservation Service's system has seven classes of soils (ranging from a high of I to a low of VII) and Classes I and II are considered to be of prime agricultural significance. Most of the City of Davis is built on prime agricultural soils, Classes I and II soils. Class III and IV soils are found in the northern and eastern portions of the planning area, with a small area to the east.

Figure 34 shows the agricultural land surrounding Davis under Williamson Act contracts. Pursuant to the California Land Conservation Act of 1965 (Williamson Act), a landowner of prime agricultural land may receive a property tax advantage in exchange for entering into a contract to maintain the land in agricultural use for at least ten years. If the landowner notifies the County that he/she wishes to terminate the contract, it normally takes ten years for the development restriction to expire. The importance of Williamson Act contracts changed with Proposition 13 property tax laws, but the contracts remain an important tool for preserving farm land.

The provisions of AB 1190 (Chapter 97, Statutes of 1992) amending various provisions of the Civic Code of the State of California, provide that certain existing agricultural processing facilities do not constitute a nuisance as long as they continue to operate in a similar manner to that in which they have historically operated. AB 1190 provides for the protection of a wide range of existing agricultural operations including, but not limited to, food processing, crop cultivation and the raising of livestock. The Hunt-Wesson Cannery and the Simmons property in East Davis fall 
under the protection of this legislation. Similarly, existing agricultural operations adjacent to the Davis city limits in unincorporated Yolo County would be protected from nuisance complaints under AB 1190.

The city has found that agricultural processing facilities (including the Hunt-Wesson facility) located within the city meet the criteria of AB 1190 . The city has also found that the provisions set forth in the noise ordinance related to AB 1190 are necessary to make the provisions of $\mathrm{AB} 1190$ conform with the city's requirements to set noise standards for various activities.

\section{Mineral Resources}

The most important mineral resources in the region are sand and gravel, which are mined on Cache Creek and other channels in Yolo County. A survey of aggregate resources by the State Division of Mines and Geology showed no significant aggregate resources in the planning area. The only mineral resource known to exist in the Planning Area is natural gas, but resource areas have not been identified.

\section{AGRICULTURE}

GOAL AG 1. Maintain agriculture as an important industry around Davis.

Policy AG 1.1 Protect agricultural land from urban development except where the general plan land use map has designated the land for urban uses.

\section{Standards}

a. New residential subdivisions and other urban development are discouraged in areas of Class 1 and 2 soils except where the General Plan land use map has designated the land for urban uses.

\section{Actions}

b. Encourage participation in the Williamson Act and/or other farmland preservation programs.

c. Establish a 150-foot minimum agricultural buffer around the City. Require dedication from developers of lands to make up the buffer concurrently with any peripheral development.

d. Continue to work with the counties, other cities and the general public to minimize conflicts with land uses such as agriculture and wildlife habitat when developing agricultural buffers. 


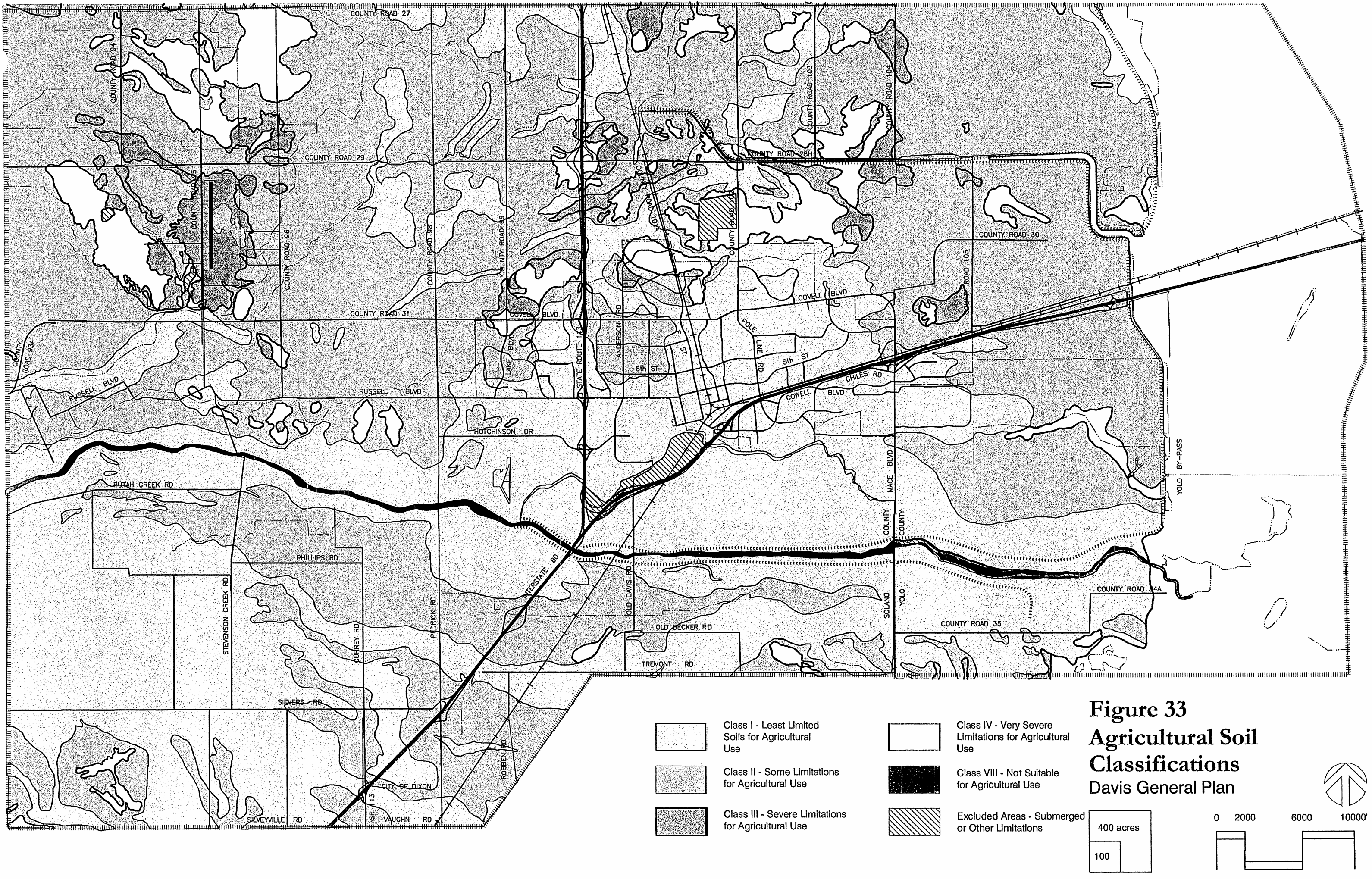




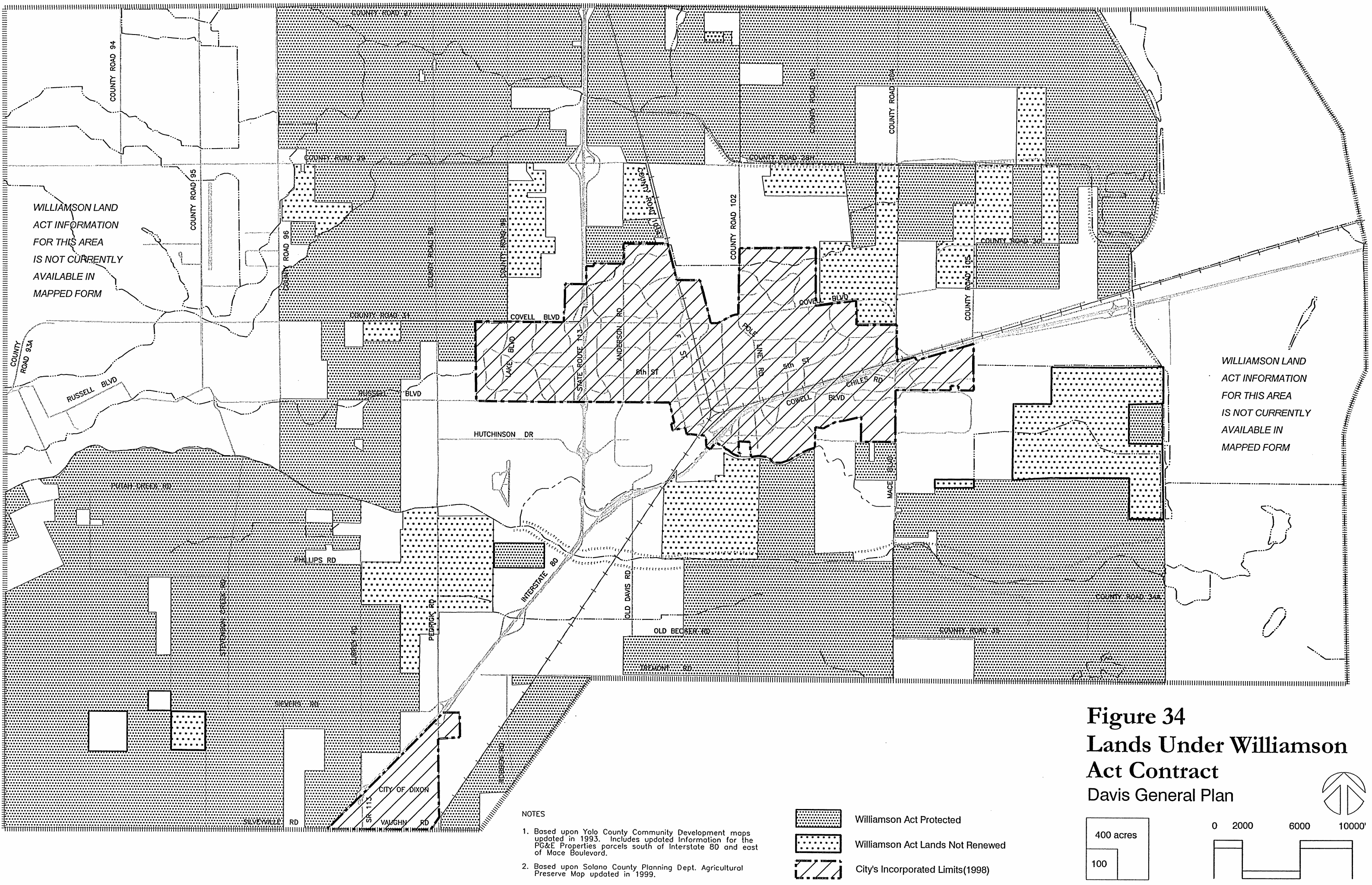


e. Implement the provisions of AB 1190 to provide that certain existing agricultural activities, operations, or facilities, or appurtenances thereof do not constitute a nuisance as long as they continue to operate in a similar manner to that in which they have historically operated.

f. Define land development guidelines for new projects proposed adjacent to existing agricultural activities, operations, or facilities. Such guidelines may include, but are not limited to, specific mitigation measures such as sound walls, landscaping, beams, and construction standards.

g. Continue to require disclosure agreements for new developments within 1,000 feet of agricultural land.

h. Urge Yolo County and Solano County to preserve agricultural land within the Davis Planning Area beyond that proposed for development.

i. Continue to implement the provisions of the Farmland Preservation Ordinance requiring buffering, notification and conflict resolution in the Planning Area. Maintain a strong right-to-farm policy.

j. In order to create an effective permanent agricultural and open space buffer on the perimeter of the City, immediately upon completion of the General Plan Update, pursue amendments of the Farmland Preservation ordinance to assure as a baseline standard that new peripheral development projects provide a minimum of 2:1 mitigation along the entire non-urbanized perimeter of the project. The proposed amendments shall allow for the alternate location of mitigations for such projects including but not limited to circumstances where the project is adjacent to land already protected by conservation easements or by some other form of public ownership that guarantees adjacent lands will not be developed.

Policy AG 1.2 Promote and enhance local agriculture.

\section{Standards}

a. Developers shall be required to reduce the impacts caused by their developments on adjacent agricultural lands in accordance with the city's right to farm and farmland preservation program. 


\section{Actions}

b. Continue to implement the farmland preservation ordinance to mitigate for the loss of agricultural land.

c. Use signage, access restrictions, fines, education and other available means to minimize trespassing into agricultural areas.

d. Maintain existing community gardens, and develop more where costs to the City are low.

e. Encourage residents to purchase produce from local farmers and community supported agriculture.

f. Support the establishment of projects to teach urban residents about the agricultural industry and to provide a forum for dialogue between urban residents and farmers.

\section{GOAL AG 2. Encourage sustainable and organic forms of agriculture.}

Policy AG 2.1 Foster the growth of environmentally friendly agricultural business and industry in Davis.

\section{Actions}

a. Maintain all City-owned community gardens as "organic" as defined by California law.

b. Develop a sustainable gardening ordinance to encourage users of city-owned community gardens to garden sustain ably.

c. With landowners, neighbors, the school district, and others, establish a "School Farm or Landscape Program" wherein schools establish and maintain an organic crop farm or landscape on nearby barren or idle sites within the City.

d. New apartment complexes should provide a gardening space for use by tenants. 


\section{SOILS}

GOAL AG 3. Conserve soil resources within the planning area.

Policy AG 3.1 Develop programs to help to conserve soil resources.

\section{Standards}

a. Tree rows or other windbreaks shall be required in buffers on the edges of urban development and in other areas as appropriate to reduce soil erosion.

b. Drainage facilities shall be designed to control runoff and minimize erosion.

\section{Actions}

c. Regulate activities that cause soil compaction and stratification.

d. Include information on soil erosion in the public water conservation program and school education program.

e. Coordinate with Yolo and Solano counties, the Resource Conservation District, and the Natural Resources Conservation Service in implementing programs to reduce soil erosion by wind and water and prevent soil contamination.

f. Work with area farmers and farming organizations to coordinate farming practices conducive to soil conservation. Provide assistance when appropriate.

\section{MINERAL RESOURCES}

GOAL AG 4. Maintain Davis' visual character and natural topography by minimizing mineral resource exploitation.

Policy AG 4.1 Discourage the extraction of mineral resources in the planning area.

\section{Actions}

a. Coordinate with County government in regulating mineral-resourceproduction operations, including sand-and-gravel mining, and oil and gas wells. 
Section VI: Community Resources Conservation

Chapter 15: Agriculture, Soils and Minerals
Davis General Plan

May 2001/ Amended Through January 2007 
40A.01.0 RIGHT TO FARM

40A.01.010 Purpose. (2)

(a)It is a goal of the city general plan to work cooperatively with the counties of Yolo and Solano to preserve agricultural land in the Davis planning area which is not otherwise identified in the general plan as necessary for development. It is the policy of the city to preserve and encourage agricultural land use and operations within the city and Yolo and Solano counties, and to reduce the occurrence of conflicts between agricultural and nonagricultural land uses and to protect the public health. One purpose of this law is to reduce the loss of agricultural resources by limiting the circumstances under which agricultural operations may be deemed a nuisance.

(b)It is also the policy of the city to provide purchasers and tenants of nonagricultural land close to agricultural land or operations with notice about the city's support of the preservation of agricultural lands and operations. An additional purpose of the notification requirement is to promote a good neighbor policy by informing prospective purchasers and tenants of nonagricultural land of the effects associated with living close to agricultural land and operations.

(c)It is further the policy of the city to require all new developments adjacent to agricultural land or operations to provide a buffer to reduce the potential conflicts between agricultural and nonagricultural land uses.

(d)Implementation of these policies can be strengthened by establishing a dispute resolution procedure designed to amicably resolve any complaints about agricultural operations that is less formal and expensive than court proceedings. (Ord. No. 1823, §1 (part).)

\section{A.01.020 Definitions. (3)}

For the purpose of this chapter, the following terms shall have the following meanings:

(a)Agricultural land. Those land areas of Yolo County specifically zoned as Agricultural Preserve (A-P), Agricultural Exclusive (A-E), and Agricultural General (A-1), as those zones are defined in the Yolo County zoning ordinances, those land areas of Solano County specifically zoned Exclusive Agricultural (A-40), as those zones are defined in the Solano County zoning ordinances, and those land areas of the city of Davis specifically zoned as Agricultural (A), Planned Development or any other zoned land as defined by the Davis Municipal Code where the land use on the land within the city limits is agricultural.

(b)Agricultural operations. Any agricultural activity, operation, or facility including, but not limited to, the cultivation and tillage of the soil, dairying, the production, irrigation, frost protection, cultivation, growing, harvesting, and processing of any commercial agricultural commodity, including timber, viticulture, apiculture or horticulture, the raising of livestock, fur-bearing animals, fish or poultry, agricultural spoils areas, and any practices performed by a farmer or on a farm as incidental to or in conjunction with such operations, including the legal application of pesticides and fertilizers, use of farm equipment, storage or preparation for market, delivery to storage or to market, or to carriers for transportation to market.

(c)Agricultural processing facilities or operations. Agricultural processing activity, operation, facility, or appurtenances thereof includes, but is not limited to, the canning or freezing of agricultural products, the processing of dairy products, the production and bottling of beer and wine, the processing of meat and egg products, the drying of fruits and grains, the packing and cooling of fruits and 
vegetables, and the storage or warehousing of any agricultural products, and includes processing for wholesale or retail markets of agricultural products.

(d)Property. Any real property located within the city limits.

(e)Transfer. The sale, lease, trade, exchange, rental agreement or gift.

(f)Transferee. Any buyer or tenant of property.

(g)Transferor. The owner and/or transferor of title of real property or seller's authorized selling agent as defined in Business and Profession Code section 10130 et. seq., or Health and Safety Code section 18006, or a landlord leasing real property to a tenant. (Ord. No. 1823, $§ 1$ (part).)

\section{A.01.030 Deed restriction. (4)}

As a condition of approval of a discretionary development permit, including but not limited to tentative subdivision and parcel maps, use permits, and rezoning, prezoning, and planned developments, relating to property located within one thousand feet of agricultural land, agricultural operations or agricultural processing facilities or operations, every transferor of such property shall insert the deed restriction recited below in the deed transferring any right, title or interest in the property to the transferee.

\section{RIGHT TO FARM DEED RESTRICTION}

The City of Davis, Yolo and Solano Counties permit operation of properly conducted agricultural operations within the City and the Counties.

You are hereby notified that the property you are purchasing is located within 1000 feet of agricultural land, agricultural operations or agricultural processing facilities or operations. You may be subject to inconvenience or discomfort from lawful agricultural or agricultural processing facilities operations. Discomfort and inconvenience may include, but are not limited to, noise, odors, fumes, dust, smoke, burning, vibrations, insects, rodents and/or the operation of machinery (including aircraft) during any 24 hour period.

One or more of the inconveniences described may occur as a result of agricultural operations which are in compliance with existing laws and regulations and accepted customs and standards. If you live near an agricultural area, you should be prepared to accept such inconveniences or discomfort as a normal and necessary aspect of living in an area with a strong rural character and an active agricultural sector.

Lawful ground rig or aerial application of pesticides, herbicides and fertilizers occur in farming operations. Should you be concerned about spraying, you may contact either the Yolo or Solano County Agricultural Commissioners.

The City of Davis' Right to Farm Ordinance does not exempt farmers, agricultural processors or others from compliance with law. Should a farmer, agricultural processor or other person not comply with appropriate state, federal or local laws, legal recourse is possible by, among other ways, contacting the appropriate agency.

In addition, the City of Davis has established a grievance procedure to assist in the resolution of disputes which arise between the residents of the City regarding agricultural operations. 
This Right To Farm Deed Restriction shall be included in all subsequent deeds and leases for this property until such time as the property is not located within 1000 feet of agricultural land or agricultural operations as defined by Davis City Code Section 40A.01.020.

(Ord. No. 1823, § 1 (part).)

\section{A.01.040 Notification to transferees. (5)}

(a)Every transferor of property subject to the notice recorded pursuant to section 40A.01.030 shall provide to any transferee in writing the notice of right to farm recited below. The notice of right to farm shall be contained in each offer for sale, counter offer for sale, agreement of sale, lease, lease with an option to purchase, deposit receipt, exchange agreement, rental agreement, or any other form of agreement or contract for the transfer of property; provided that the notice need be given only once in any transaction. The transferor shall acknowledge delivery of the notice and the transferee shall acknowledge receipt of the notice.

(b)The form of notice of right to farm is as follows:

\section{NOTICE OF RIGHT TO FARM}

The City of Davis, Yolo and Solano Counties permit operation of properly conducted agricultural operations within the City and the Counties.

You are hereby notified that the property you are purchasing/leasing/ renting is located within 1000 feet of agricultural land, agricultural operations or agricultural processing facilities or operations. You may be subject to inconvenience or discomfort from lawful agricultural or agricultural processing facilities operations. Discomfort and inconvenience may include, but are not limited to, noise, odors, fumes, dust, smoke, burning, vibrations, insects, rodents and/or the operation of machinery (including aircraft) during any 24 hour period.

One or more of the inconveniences described may occur as a result of agricultural operations which are in compliance with existing laws and regulations and accepted customs and standards. If you live near an agricultural area, you should be prepared to accept such inconveniences or discomfort as a normal and necessary aspect of living in an area with a strong rural character and an active agricultural sector.

Lawful ground rig or aerial application of pesticides, herbicides and fertilizers occur in farming operations. Should you be concerned about spraying, you may contact either the Yolo or Solano County Agricultural Commissioners.

The City of Davis' Right to Farm Ordinance does not exempt farmers, agricultural processors or others from compliance with law. Should a farmer, agricultural processor or other person not comply with appropriate state, federal or local laws, legal recourse is possible by, among other ways, contacting the appropriate agency.

In addition, the City of Davis has established a grievance procedure to assist in the resolution of disputes which arise between the residents of the City regarding agricultural operations.

This notification is given in compliance with Davis City Code section 40A.01.040. By initialling below, you are acknowledging receipt of this notification. 


\section{Transferor's InitialsTransferee's Initials}

(c)The failure to include the foregoing notice shall not invalidate any grant, conveyance, lease or encumbrance.

(d)The notice required by this section 40A.01.040 shall be included in every agreement for transfer entered into after the effective date of this chapter, including property subject to the deed restriction cited in section 40A.01.030. (Ord. No. 1823, § 1 (part).)

\section{A.01.050 Agricultural buffer requirement. (6)}

(a) In addition to the right to farm deed restriction and notice requirement, the city has determined that the use of property for agricultural operations is a high priority. To minimize future potential conflicts between agricultural and nonagricultural land uses and to protect the public health, all new developments adjacent to designated agricultural, agricultural reserve, agricultural open space, greenbelt/agricultural buffer, Davis greenbelt or environmentally sensitive habitat areas according to the land use and open space element maps shall be required to provide an agricultural buffer/agricultural transition area. In addition, development limits or restricts opportunities to view farmlands. Public access to a portion of the agricultural buffer will permit public views of farmland. Use of nonpolluting transportation methods (i.e., bikes), and use of the land to fulfill multiple policies including, but not limited to, agricultural mitigation and alternative transportation measures meets the policy objectives of the Davis general plan. The agricultural buffer/agricultural transition area shall be a minimum of one hundred fifty feet measured from the edge of the agricultural, greenbelt, or habitat area. Optimally, to achieve a maximum separation and to comply with the five hundred foot aerial spray setback established by the counties of Yolo and Solano, a buffer wider than one hundred fifty feet is encouraged.

(b) The minimum one hundred fifty foot agricultural buffer/agricultural transition area shall be comprised of two components: a fifty foot wide agricultural transition area located contiguous to a one hundred foot wide agricultural buffer located contiguous to the agricultural, greenbelt, or habitat area. The one hundred fifty foot agricultural buffer/transition area shall not qualify as farmland mitigation pursuant to article III of this chapter.

(c) The following uses shall be permitted in the one hundred foot agricultural buffer: native plants, tree or hedge rows, drainage channels, storm retention ponds, natural areas such as creeks or drainage swales, railroad tracks or other utility corridors and any other use, including agricultural uses, determined by the planning commission to be consistent with the use of the property as an agricultural buffer. There shall be no public access to the one hundred foot agricultural buffer unless otherwise permitted due to the nature of the area (e.g., railroad tracks). The one hundred foot agricultural buffer shall be developed by the developer pursuant to a plan approved by the parks and community services director or his/her designee. The plan shall include provision for the establishment, management and maintenance of the area. The plan shall incorporate adaptive management concepts and include the use of integrated pest management techniques. The property shall be dedicated to the city in fee title, or, at the discretion of the city, an easement in favor of the city shall be recorded against the property, which shall include the requirements of this article.

(d) The following uses shall be permitted in the fifty foot agricultural transition area: bike paths, community gardens, organic agriculture, native plants, tree and hedge rows, benches, lights, trash enclosures, fencing, and any other use determined by the planning commission to be of the same general character as the foregoing enumerated uses. There shall be public access to the fifty foot 
agricultural transition area. The fifty foot agricultural transition area shall be developed by the developer pursuant to a plan approved by the parks and community services director or his/her designee. Once the area is improved, approved, and accepted by the parks and community services department, the land shall be dedicated to the city.

(e) The city reserves its right to form a special benefit assessment district, or other applicable district as is permitted under state law, and to maintain the agricultural buffer and transition area once the land is improved, dedicated, and annexed.

(Ord. No. 1823, § 1 (part); Ord. No. 2300, § 2, Amended 11/27/2007) 


\section{Appendix D}

\section{City of Napa, CA}

Land Use Element of the General Plan - Goals, Policies and Implementation Programs for Agricultural Buffers

Development Code Chapter 17.52.040 - Agricultural Buffers 


\section{GoAls, Policies AND IMPLEMENTATION MEASURES}

The overall focus of this section is on setting standards and policies for future development and redevelopment in Napa, focusing on growth that is consistent with the city's small-town qualities and neighborhood character, and providing for continued open space.

This section is organized under the following major headings;

$v$ Community Character and Identity

$v$ Rural Urban Limit

$v$ Growth Management

$v$ Residential Neighborhoods

$v$ Economic Development/Nonresidential Development

- Commercial

- Downtown

- Industrial

- $\quad$ Mixed Use

$v \quad$ Napa River

$v$ Urban Form and Open Space

$v \quad$ Economic Development Strategies

\section{COMMUNITY CHARACTER AND IDENTITY}

While Napa by most measures is a medium-sized city, residents typically think of Napa as a small town. The city's small-town character and qualities are important to its identity. Key elements of Napa's small-town qualities are its stable and friendly neighborhoods, the mix of housing types and sizes, local schools, and a traditional central Downtown. Napa has a significant resource in its historic buildings and cultural assets. The surrounding open space is visible from almost everywhere in the city, and separates the community from other areas.

Goals, policies, and implementation programs throughout the General Plan focus on preserving and enhancing Napa's special community identity by managing future growth, maintaining the qualities of its neighborhoods, providing for maintenance of surrounding open space. This section also recognizes and urges particular actions to protect the city's gateways and its historic resources which contribute to its identity. (Also see Appendix F, Open Space Action Program)

To maintain and enhance Napa's small-

\section{GOAL town qualities and unique community LU-1}

\section{Policies}

LU-1.1 The City shall maintain the Rural Urban Limit (RUL) and Greenbelt designation to define the extent of urban development through the year 2020 and to provide for the maintenance of the city's surrounding open space/agriculture to separate Napa from other communities.

LU-1.2 The City shall strive to preserve and enhance the integrity of existing neighborhoods and to develop new neighborhoods with similar qualities as the existing neighborhoods.

LU-1.3 The City shall recognize downtown as an important asset of the city and seek to strengthen and revitalize it.

LU-1.4 The City shall recognize the importance of historic properties, districts, and aesthetic resources as contributors to the city's identity. See also Chapter 6, Historic Resources and Chapter 7, Natural Resources.

LU-1.5 The City shall refine the locations and concept of the key gateways to the city identified in Figure 1-3, and shall establish gateway and scenic corridor design guidelines for both public and private development to ensure attractive entrances to the city. Greenways, open space, riparian corridors, wetland areas and agricultural land shall be considered as important components when they exist in gateway locations.

LU-1.6 The City shall designate SR 29, SR 121, and SR 221 as scenic corridors. The City shall endeavor to improve the scenic character of these roads through undergrounding of utilities, increased landscaping, street tree planting, and other improvements.

LU-1.7 The City shall enhance the Napa River as a natural corridor and recreational spine connecting neighborhoods, employment areas, and other destinations. (See Chapter 5, Parks and Recreation). 


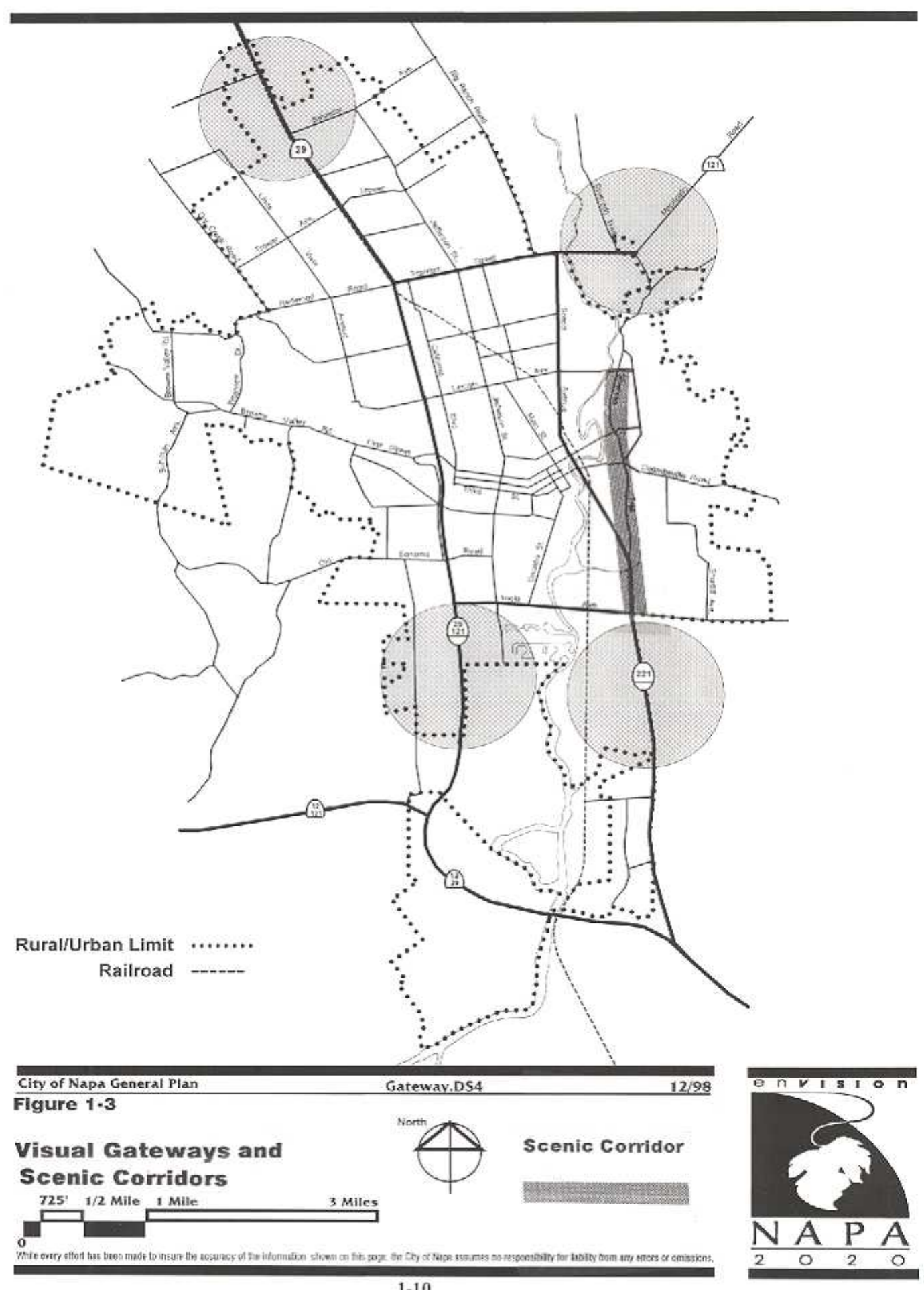


LU-1.8 The City shall strive to preserve its urban forest by maintaining its street tree program and encouraging the preservation of trees on private property.

LU-1.9 The City shall support cooperative planning with other Napa County jurisdictions to achieve common interests.

LU-1.10 The City shall work with the County to identify revenue-sharing opportunities.

\section{IMPLEMENTATION PROGRAMS}

LU-1.A The City shall initiate further study to: 1) define gateway locations, with consideration to the importance of all entrances to the city; and, 2) prepare and adopt gateway design guidelines for private and public development at the key gateway and scenic locations.

Responsibility: Planning Department; Redevelopment and Economic Development Coordinator; City Council

Time Frame: FY 03-05

LU-1.B The City shall revise the Zoning Ordinance to include a Scenic Corridor Overlay Zone to apply to the scenic corridors identified in Policy LU-1.5.

$\begin{array}{ll}\text { Responsibility: } & \text { Planning Department; } \\ & \text { Planning Commission; } \\ & \text { City Council } \\ \text { Time Frame: } & \text { FY 05-07 }\end{array}$

LU-1.C The City shall identify other major streets in the City which are important to the city's character, history, and identity (e.g., Soscol Avenue) and establish corridor streetscape design guidelines that will address adjacent land uses, signage, landscaping, street tree planting, and placement of public parking along these designated corridors.

$\begin{array}{ll}\text { Responsibility: } & \begin{array}{l}\text { Planning Department; } \\ \text { Cultural Heritage } \\ \text { Commission; }\end{array} \\ & \text { City Council } \\ \text { Time Frame: } & \text { FY 05-07 }\end{array}$

\section{RURAL URBAN LIMIT}

Napa has a long history as a self-contained city with its own industry, a diverse population, and a full range of services. In the 1970s, the residents of Napa felt that the character of their community was threatened by unrestrained development. Fueled by a burgeoning regional economy, communities throughout the Bay Area were sprawling onto irreplaceable agricultural land as pressures for development spread from the larger core cities. Previously distinct cities were blending together into undistinguishable suburbs.

Napa was perhaps the first city in the region to act to protect its agricultural, small-town heritage. In 1973 the voters established the basis for what became the Rural Urban Limit line (RUL), an urban growth boundary identifying a limited area subject to urban development. The RUL has remained in place, virtually unchanged, for the past 20 years. County initiatives and policy have cooperated in preserving the integrity of the RUL.

This plan retains the RUL virtually unchanged for the next 25 years. A critical element to making the RUL successful is continuing cooperation with the County and neighboring cities in protecting surrounding open space lands, which is promoted by various policies throughout this plan. Maintenance of the Greenbelt designation on lands outside the RUL furthers the General Plan objectives for protecting open space lands.

\section{GOAL To maintain the Rural Urban Limit LU2 (RUL) to contain urban development and support Napa County's agricultural and other resource uses.}

\section{Policies}

LU-2.1 The Rural Urban Limit (RUL) shall define the extent of urban development through the year 2020.

LU-2.2 The City shall continue to cooperate with the County to ensure that land proposed for development within the RUL is annexed to the city, and land outside of the RUL is conserved primarily for agriculture and other resource and open space uses.

See Chapter 10, Administration, for criteria for considering any General Plan amendments that would modify the RUL. 


\section{GROWTH MANAGEMENT}

As a result of Napa's RUL and other strategies, growth in Napa has been relatively slow by the standards of other communities on the fringe of the Bay Area. Rather than the 4 to 5 percent annual growth rates experienced by such communities as Fairfield or Vacaville, the city of Napa's housing stock grew at an annual average rate of 1.3 percent between 1980 and 1990, a rate comparable to the average for the Bay Area as a whole.

The RUL generally contains the incorporated lands of the city of Napa and "county pockets" where residents have declined to become incorporated into the city, even though these areas are surrounded by land under City jurisdiction.

Outside the city limits but still within the RUL is undeveloped land ultimately planned for development, such as the Big Ranch area, along with areas of unincorporated development.

To preserve its diversity and its economic vitality while limiting the city's outward expansion, the plan establishes a growth monitoring and management program.

\section{GOAL To maintain an even rate of LU development within the RUL over the LU-3 time frame of the General Plan.}

\section{POLICIES}

LU-3.1 The City shall prezone unincorporated land within the RUL to ensure the orderly transition of land uses within the city's urbanizable area.

LU-3.2 To minimize urban/rural conflicts (e.g., pesticides, odors, noise, vandalism, feral pets), the City shall ensure a buffer is provided (agricultural setback) between residential uses on the periphery of the RUL and productive agricultural land outside the RUL.

LU-3.3 (deleted 12/4/01; R2001 274)

LU-3.3 The City shall endeavor to maintain an even rate of development within the RUL over the plan period.

LU-3.4 The City shall provide for the efficient development and redevelopment of land within the RUL in order to allow job and housing growth through the end of the planning period.

LU-3.5 The City shall program land uses so as to maximize the use of available public facilities and minimize the need for new facilities.

LU-3.6 The City shall maintain adequate supply of land designated for residential uses to accommodate the plan's projected population growth. To this end, the City shall monitor the ability of the plan to achieve this growth through such means as monitoring of plan changes from residential to nonresidential designations, preparation and review of annual growth management reports, and other measures as appropriate, and shall undertake responsive actions as necessary.

LU-3.7 The City shall monitor county employment and housing development trends to evaluate their impacts on the city's jobs/housing balance.

LU-3.8 The City shall coordinate growth and development with surrounding jurisdictions, the Local Agency Formation Commission (LAFCO), Congestion Management Agency, Napa County Flood Control District, and other agencies as appropriate to maintain open space between communities and promote common goals.

LU-3.9 The City shall encourage the use of special committees, joint boards, and other efforts to coordinate the management of growth and development, especially in relation to jobs/housing balance, transportation, and flood control issues.

\section{IMPLEMENTATION PROGRAMS}

LU-3.A The City shall work with LAFCO to complete a sphere study and establish a revised sphere of influence consistent with the city's RUL, LAFCO laws, and applicable criteria.

\section{Responsibility: City Council; \\ Time Frame: FY 99-03}

LU-3.B The City shall institute a development monitoring program that will include annual growth monitoring reports to the City 
Council covering the rate, type and amount of residential, commercial, and industrial activity, comparing the rate to the previous one- and five-year periods.

$\begin{array}{ll}\text { Responsibility: } & \text { City Council; } \\ & \text { Planning Department } \\ \text { Time Frame: } & \text { Annually }\end{array}$

LU-3.C The City shall prepare projections of future absorption rates and employment development to guide future City Council policy.

Responsibility: City Council; Redevelopment and Economic Development Coordinator

Time Frame: Annually

LU-3.D The City shall review and strengthen its agricultural buffer standards (landscape buffer widths, plant materials within the landscape buffer and setback distances) to address new concerns such as Pierce's disease and to assure it continues to meet its purpose of minimizing conflicts between agricultural and urban residential uses. (amend 12/4/02; R2001 274)

$\begin{array}{ll}\text { Responsibility: } & \text { City Council; } \\ & \text { Planning Department } \\ \text { Time Frame: } & \text { FY 2001-2002 }\end{array}$

\section{RESIDENTIAL NeIGHBORHOODS}

Napa includes residents from all walks of life and a diverse housing stock to meet their needs. According to California Department of Finance estimates, of the city's 26,577 homes (1995), 62 percent were single-family detached homes, 25 percent were multiple family units, 7 percent attached single-family homes and another 5 percent mobile homes. The city's housing stock ranges from the merchant mansions built in the late 1800s in the "Old Town" area near downtown, to the working class cottages of the early 1900s, to the traditional ranch style subdivisions of the 1950s and 60s, to the large custom homes of the 1990s. Multi-family housing is found in different areas of the city, with most concentrated along major streets such as Soscol and Freeway Drive. Mobile home parks are also found throughout the city as are a variety of residential care facilities for the elderly.

Perhaps the strongest sentiment to arise from the extensive public outreach program conducted during the General Plan update process was the community's desire to conserve the character of existing neighborhoods. Accompanying the desire to conserve neighborhood character was the desire to ensure that the diversity of housing types and people that characterizes Napa today would be retained into the future.

The approach to neighborhood conservation used in this General Plan focuses on first identifying the special physical characteristics that define a neighborhood, and then applying strategies which conserve those qualities.

The plan strongly encourages new infill development to be patterned after existing nearby development; consistency with the design characteristics of the adjacent neighborhood is especially important.

Each city neighborhood is classified as one of seven neighborhood "types." Many factors were considered in defining those types: the age and type of homes, the relationship of homes to the street, and the diversity or homogeneity of housing styles. Some areas are highly diverse; other areas are homogenous where highly divergent styles would disrupt that neighborhood pattern. These seven typologies are summarized in Table 1-3 and explained more thoroughly in Appendix B.

Neighborhoods are further subdivided into "pods", smaller geographic units that are described in the Land Use Diagram with specific density standards. By requiring that new development conform to a few defining neighborhood characteristics and requiring that the density of new development be within specified ranges similar to existing development, the land use plan ensures that future infill development is consistent with the character of the surrounding neighborhood, while allowing enough flexibility to ensure that each new home need not look exactly like its neighbors.

Major new undeveloped areas (i.e., Big Ranch) include designations based on specific plans that have been adopted during the General Plan update process. 
Table 1-3

\section{NEIGHBORHOOD TYPOLOGIES}

TYPE A

Post War Tract Subdivisions

TYPE B

Estate Residential

top

TYPE C

Period Tract Subdivisions

TYPE D

Ranchettes

\begin{tabular}{l} 
\\
\hline
\end{tabular}

TYPE E

Deep Lot Subdivisions

TYPE F

Traditional Neighborhoods

TYPE G

Attached Unit Residential
Characterized by uniformity in platting patterns, street designs, building types, and relationship of home to lot (i.e., uniform setbacks).

Characterized by platting patterns with large, regularly shaped lots and custom homes that vary in lot placement and structural and landscape design. The pattern of these areas was generally established through subdivision of large tracts of vacant land. Irregular lot configurations and curvilinear street systems are a result of topography and other natural constraints.

Characterized by homogeneous platting patterns of lots up to one-half acre along gridiron or curvilinear streets. Include some diversity of building types and maintenance levels since structures were developed over time.

Land divided over time through multiple land partition actions. Include a large number of irregularly shaped and/or sized lots, typically from one to five acres in size. Diversity in physical neighborhood character factors (e.g., varying architectural style and period). Often lack public improvements such as streetscaping and sidewalks.

Characterized by large, regularly-shaped lots that are most often developed with post-1950 homes. Lot width to depth ratios typically exceed 1:3. Development patterns generally include regular individual lot setbacks and house sizes. Street patterns are usually gridiron and are often narrow.

Characterized by small lots laid out in a predominantly gridiron pattern; radial streets and alley may also be included in the street grid. These areas were typically platted before the 1930s, with "period" architecture. Uses include a mix of housing types.

Dominated by residential uses other than single-family detached homes; primarily attached unit residential structures that vary in scale from concentrations of duplexes and triplexes through areas dominated by apartment and condominium/townhome development. Irregular platting patterns and lot sizes, often with extensive public and private improvements. 
Chapter 17.52

\section{SITE AND USE REGULATIONS}

Sections:

17.52.010

17.52.020

17.52.030

17.52.040

17.52.050

17.52.060

17.52.070

17.52 .080

17.52 .090

17.52.095

17.52.100

17.52 .110

17.52.120

17.52.130

17.52.140

17.52.150

17.52.160

17.52 .170

17.52 .180

17.52.190

17.52.200

17.52.210

17.52.220

17.52.230

17.52.240

17.52 .250

17.52.260

17.52.270

17.52 .280

17.52 .290

17.52.300

17.52.310

17.52.320

17.52.330

17.52 .340

17.52 .350

17.52 .360

17.52.370

17.52 .380

17.52 .390

17.52 .400

17.52 .410

17.52 .420

17.52 .430

17.52.440

17.52 .450

17.52 .460

17.52 .470

17.52 .480
Specific Purposes and Applicability.

Accessory Structures including Second Units (Residential Districts).

Adult-Oriented Businesses.

Agricultural Buffers.

Agricultural Cultivation and Animal Keeping.

Bed and Breakfast Inns.

Cocktail Lounges, Bars and Commercial Recreation.

Condominium Conversion Use Permits.

Condominium Standards.

Condo-Hotels.

Conversion of Residential to Non Residential Uses.

Creeks and Watercourses.

Density and FAR Calculations.

Density Bonuses.

Density Flexibility.

Development Agreements.

Drive-Through Facilities/Uses.

Fences, Walls and Hedges.

Fire Hazard Areas.

Flag Lots.

Grading while Application Processed.

Height Bonus.

Height Limit Exclusions.

Historic Preservation.

Home Occupations.

House Moving.

Lot Access Requirement.

Lot Consolidation when Development Occurs.

Mixed Use Development Objectives.

Mobile Home Park Conversions.

Napa River/Napa Creek Flood Protection Project.

Noise Standards.

Nonconforming Uses and Structures.

Outdoor Display or Sale of Merchandise, Accessory.

Outdoor Dining.

Outdoor Storage Screening.

Pedestrian Friendly Street and Setback Standards.

Projections over Easements, Sidewalks.

Recycling Facility, Small.

Recycling/Solid Waste Areas.

Religious Institutions.

Satellite Dishes, Accessory.

Seismic/Landslide Hazard Areas.

Setback and Yard Determinations in Unusual Cases.

Setback and Yard Projections.

Setback Area Storage Limits.

Single Room Occupancies (SRO's).

Small Lot Development.

Telecommunication facilities. 
Temporary Uses and Structures.

17.52 .500

Time Shares.

17.52.510 Tree Protection.

17.52.515 Vacation Rental - Interim Permits.

17.52 .520

17.52 .530 Water Efficient Landscaping.

17.52.540 Wetlands/marshes.

Wineries.

\subsubsection{Specific Purposes and Applicability.}

Site and use regulations are applicable to sites in all or several districts. They are intended to ensure that new uses and development will contribute to and be harmonious with existing development and consistent with the policies of the General Plan. These regulations shall be applied as specified in this Title.

(O2003 12)

\subsubsection{Accessory Structures and Uses, including Second Units (Residential Districts).}

A. Detached structures not used as dwellings or living quarters shall comply with the following standards:

Standards- Detached Accessory Structures not used as Dwellings or Living Quarters

1. Coverage:

2. Height:

3. Front Setback:

4. Side Setback:

5. Side/Rear Yards:

6. Distance between principal dwelling and any detached accessory structure(s) at least partly within a required yard or setback:

B. Detached Accessory Structures with Plumbing shall meet the following requirements in addition to those described in 17.52.020A:

1. An Administrative Permit shall be required for the following construction:

a. Installation of a toilet or a 3 inch drain line required for a toilet;

b. The construction, expansion, or structural alteration (excluding ordinary maintenance) of an accessory structure that has a toilet or a three inch drain line;
Up to $50 \%$ of a required yard.

15 feet or 1.5 stories, whichever is more restrictive. The Community Development Director may grant an exception for an increase in height up to 18 feet. See 17.56 (Exceptions). Added height up to the Use Permit.

Not permitted, except fences or signs meeting fence or sign standards. For parking in setbacks, see 17.54 approved, in which case an accessory structure may be approved on the interior side of the fence up to 2 feet higher than the height of the fence. See 17.52.170 (Fences).

feet (except fences) unless a reduction is approved by the Chief Building Official after determining that fire containment, drainage and to building permit issuance for any accessory structure larger than 120 sq. ft. proposed closer than 3 feet to the property line, the owner shall provide a maintenance easement acceptable to the City for maintenance of the exterior wall in proximity to the common property line.

6 feet wall to wall, for structure separation, maintenance and accessible access. 
c. Prior to issuance of a building permit, the property owner shall sign an agreement acceptable to the City that the accessory structure shall not be used for living quarters, cooking or sleeping purposes.

C. Accessory Second Units (or Living Quarters). An Accessory Second Unit (or Living Quarter) shall meet standards in 1 below. (Such units are exempt from general plan density requirements).

1. An Administrative Permit is required to determine compliance with the following standards:

\begin{tabular}{|c|c|c|}
\hline \multicolumn{3}{|c|}{ Standards - Accessory Second Unit or Living Quarter } \\
\hline a. & Height limits: & Same as for the principal dwelling. \\
\hline b. & Setbacks and yards. & Same as for the principal dwelling, except for alley units. \\
\hline c. & Alley unit setbacks, yards: & $\begin{array}{l}0 \text { feet from alley minimum, provided that } 40 \% \text { of the alley } \\
\text { frontage has a } 5 \text { foot wide landscape area, and } 5 \text { feet } \\
\text { maximum. Side setbacks and side yards are same as for the } \\
\text { principal dwelling. }\end{array}$ \\
\hline d. & Number: & $\begin{array}{l}1 \text { accessory second unit per single family detached or single } \\
\text { family attached lot. Accessory second unit provisions do not } \\
\text { apply to duplex, triplex, or apartment lots. }\end{array}$ \\
\hline e. & Location: & $\begin{array}{l}\text { The accessory second unit may be within or detached from the } \\
\text { principal dwelling. }\end{array}$ \\
\hline f. & Size: & Up to 640 square feet. \\
\hline g. & Parking: & $\begin{array}{l}1 \text { space per unit or per bedroom, whichever is greater, covered } \\
\text { or uncovered onsite in addition to the required parking for the } \\
\text { principal dwelling. }\end{array}$ \\
\hline h. & Existing dwelling: & $\begin{array}{l}\text { There is an existing or a proposed principal dwelling (must } \\
\text { have submitted building plans) on the lot. }\end{array}$ \\
\hline i. & Owner Occupancy: & $\begin{array}{l}\text { The property owner shall occupy either the principal single } \\
\text { family dwelling or the accessory second unit. }\end{array}$ \\
\hline j. & Design statement. & $\begin{array}{l}\text { Applicants shall describe in writing how their proposal } \\
\text { addresses the city's adopted Residential Design Guidelines } \\
\text { section on Second Units. }\end{array}$ \\
\hline $\mathrm{k}$. & Design standards. & $\begin{array}{l}\text { All accessory second units/living quarters shall meet the } \\
\text { following design standards: } \\
\text {-Building materials, colors and windows shall match, i.e., have } \\
\text { the same appearance as, those of the principal dwelling. } \\
\text {-Roof slopes shall generally match those of the principal } \\
\text { dwelling, i.e., be within } 8 \% \text { of the roof slope. }\end{array}$ \\
\hline
\end{tabular}

2. The property owner, as part of the application for an Administrative Permit, shall execute a declaration acknowledging the requirement of owner occupancy. Upon granting of the Administrative Permit, the Community Development Director shall cause the declaration to be recorded in the office of the County Recorder. The Community Development Director may waive recordation of the declaration if a declaration acknowledging the requirement of owner occupancy has already been recorded for the property.

The declaration shall be in substantially the following form:

\section{"DECLARATION ACKNOWLEDGING OWNER OCCUPANCY}

The undersigned does hereby certify to be the owner(s) of certain real property located in the City of Napa, and more particularly described in Exhibit " $A$ " attached hereto and incorporated herein by this reference ("the subject property")

The undersigned does hereby acknowledge that the administrative permit that has been issued by the City of Napa for a second residential unit on the subject property requires the property owner to occupy either the principal single family 
dwelling or the accessory second unit.

This Declaration shall run with the subject property in perpetuity and shall be binding upon the undersigned and the undersigned's heirs, personal representatives, lessees, executors, successors, and assigns. This Declaration and the acknowledgements contained herein shall be disclosed to prospective transferees of any interest in the subject property prior to any such transfer.

IN WITNESS WHEREOF, the undersigned has/have executed this Declaration this day of , 20

DECLARANT (S)

Dated:

Dated:

NOTE: ACKNOWLEDGMENTS MUST BE ATTACHED FOR ALL SIGNATORIES"

3. Accessory second unit parking requirements may be considered for waiver by a Planning Commission Use Permit. The Use Permit shall only evaluate the parking issue. The Commission may approve the Use Permit if it finds:

a. Adequate curb parking is available adjacent to the property, or

b. Onsite parking for the accessory second unit is not needed.

4. If a second unit is proposed as an upper story addition, see Chapter 17.62 (Design Review), as all residential upper story additions require design review. The Design Review permit shall only evaluate the design of the addition. Similarly, remodel of an historic building must comply with the City's Historic Preservation Ordinance in Title 15.

5. Accessory Second Units between 641 and $900 \mathrm{sq}$. ft. may be considered with a Planning Commission Design Review Permit for compatibility with the Residential Design Guidelines and also using the following as a guide: up to 700 sq. ft. on lots $>7,000$ to 10,000 sq. ft; up to 800 sq. ft. on lots $>10,000$ sq. ft to 20,000 sq. ft; up to 900 sq. ft on lots $>20,000$ sq. ft.

(O2003 12)

\subsubsection{Adult-Oriented Businesses.}

A. Purpose. Studies conducted by cities around the country that have been reviewed by the City of Napa demonstrate that Adult-Oriented Businesses which are not regulated as to permissible locations often have a deleterious effect on nearby businesses and residential areas causing, among other adverse secondary effects, an increase in crime and a decrease in property values. Special regulation of AdultOriented Businesses is necessary, therefore, to ensure that their adverse secondary side effects will not contribute to an increase in crime rates or to the blighting or deterioration of the areas in which they are located or in surrounding areas. The purpose and intent of these special regulations is to prevent the concentration of AdultOriented Businesses, and other public places at which Adult-Oriented Performances are conducted, and thereby prevent such adverse secondary side effects. The location requirements established by these regulations do not unreasonably restrict the establishment or operation of constitutionally protected Adult-Oriented Businesses in the City of Napa, and a sufficient and reasonable number of appropriate locations for Adult-Oriented Businesses are provided by the Zoning Ordinance.

B. Definitions.

1. "Establishment of an Adult-Oriented Business" shall mean any of the following:

a. The opening or commencement of any Adult-Oriented Business as a new business; 
b. The conversion of an existing business, whether or not an Adult-Oriented Business, to any Adult-Oriented Business defined herein;

c. The addition of any of the Adult-Oriented Businesses defined herein to any other existing Adult-Oriented Business, or

d. The relocation of any such Adult-Oriented Business.

2. "Specified Anatomical Areas" shall mean and include any of the following:

a. Less than completely and opaquely covered human (i) genitals or pubic region; (ii) buttocks; and (iii) female breast below a point immediately above the top of the areola;

b. Human male genitals in a discernibly turgid state, even if completely and opaquely covered;

c. Any device, costume or covering that simulates any of the body parts included in sections 1 or 2 above.

3. "Specified Sexual Activities" shall mean and include any of the following, whether performed directly or indirectly through clothing or other covering:

a. The fondling or other erotic touching of human genitals, pubic region, buttocks, anus or female breast;

b. Sex acts, actual or simulated, including intercourse, oral copulation or sodomy;

c. Masturbation, actual or simulated;

d. Excretory functions as part of or in connection with any of the other activities described in section 1 through 3 above.

4. "Adult-Oriented Businesses" shall mean any one of the following:

a. Adult arcade. An establishment where, for any form of consideration, one or more still or motion picture projectors, or similar machines, for viewing by 5 or fewer persons each, are used to show films, computer generated images, motion pictures, video cassettes, slides or other photographic reproductions thirty percent (30\%) or more of the number of which are distinguished or characterized by an emphasis upon the depiction or description of specified sexual activities or specified anatomical areas.

b. Adult bookstore. An establishment that has thirty percent (30\%) or more of its stock in books, magazines, periodicals or other printed matter, or of photographs, films, motion pictures, video cassettes, slides, tapes, records or other form of visual or audio representations which are distinguished or characterized by an emphasis upon the depiction or description of specified sexual activities and/or specified anatomical areas;

c. Adult cabaret. A nightclub, restaurant, or similar business establishment which: (i) regularly features live performances which are distinguished or characterized by an emphasis upon the display of specified anatomical areas or specified sexual activities; and/or (ii) which regularly features persons who appear semi-nude; and/or (iii) shows films, computer generated images, motion pictures, video cassettes, slides or other photographic reproductions thirty percent (30\%) or more of the number of which are distinguished or characterized by an emphasis upon the depiction or description of specified sexual activities or specified anatomical areas;

d. Adult hotel/motel. A hotel or motel or similar business establishment offering public accommodations for any form of consideration which (i) provides patrons with closed-circuit television transmissions, films, computer generated images, motion pictures, video cassettes, slides or other photographic reproductions thirty percent $(30 \%)$ or more of the number of which are distinguished or characterized by an emphasis upon the depiction or description of specified sexual activities or specified anatomical areas and (ii) rents, leases or lets any room for less than a 6 
hour period, or rents, leases or lets any single room more than twice in a 24-hour period;

e. Adult motion picture theater. A business establishment where, for any form of consideration, films, computer generated images, motion pictures, video cassettes, slides or similar photographic reproductions are shown, and thirty percent (30\%) or more of the number of which are distinguished or characterized by an emphasis upon the depiction or description of specified sexual activities or specified anatomical areas;

f. Adult theater. A theater, concert hall, auditorium, or similar establishment which, for any form of consideration regularly features live performances which are distinguished or characterized by an emphasis on the display of specified anatomical areas or specified sexual activities;

g. Modeling studio. A business which provides, for pecuniary compensation, monetary or other consideration, hire or reward, figure models who, for the purposes of sexual stimulation of patrons, display "specified anatomical areas" to be observed, sketched, photographed, painted, sculpted or otherwise depicted by persons paying such consideration. "Modeling studio" further does not include a studio or similar facility owned, operated, or maintained by an individual artist or group of artists and which does not provide, permit or make available "specified sexual activities."

5. "Distinguished or Characterized by an Emphasis Upon" shall mean and refer to the dominant or essential theme of the object described by such phrase. For instance, when the phrase refers to films "which are distinguished or characterized by an emphasis upon" the depiction or description of specified sexual activities or specified anatomical areas, the films so described are those whose dominant or predominant character and theme are the depiction of the enumerated sexual activities or anatomical areas.

6. "Public place". Any area to which the public is invited or in which the public is permitted.

7. "Regularly Features" with respect to an adult theater or adult cabaret shall mean a regular and substantial course of conduct. The fact that live performances which are distinguished or characterized by an emphasis upon the display of specified anatomical areas or specified sexual activities occurs on 2 or more occasions within a 30 day period; 3 or more occasions within a 60 day period; or 4 or more occasions within a 180 day period shall to the extent permitted by law be deemed to be a regular and substantial course of conduct.

8. "Religious Institution". A structure which is used primarily for religious worship and related religious activities.

9. "School". For purposes of this section school shall mean any child or day care facility, or an institution of learning for minors, whether public or private, offering instruction in those courses of study required by the California Education Code and maintained pursuant to standards set by the State Board of Education. This definition does not include a vocational or professional institution of higher education, including a community or junior college, college or university.

10. "Semi-Nude". A state of dress in which clothing covers no more than the genitals, pubic region, buttocks, areola of the female breast, as well as portions of the body covered by supporting straps or devices.

C. Location of Adult-Oriented Businesses.

1. Adult-Oriented Businesses shall be permitted uses only in the Industrial Park IP-C zoning district, and in the Light Industrial IL District on Kaiser Road and Enterprise Way, and shall be prohibited in all other locations.

2. No Adult-Oriented Business shall be permitted within 300 feet of any (a) property zoned for residential use in existence on the effective date of this Chapter; (b) park listed in Section 12.32.010 of this Code on the effective date 
of this Chapter; (c) school or day care facility in existence on the effective date of this Chapter; or (d) State Highway or (e) other Adult-Oriented Business.

D. Signs. The following provisions shall apply to signs erected or maintained for or in connection with an Adult-Oriented Business:

1. No off-site signs shall be permitted.

2. The total sign area, as defined in Title 15, allowed in connection with any Adult-Oriented Business shall not exceed 15 square feet. The area of signs affixed to or placed within windows which are visible from any public area shall be included for the purposes of this restriction.

E. Public Display of Certain Matter Prohibited. Materials offered for sale from or by an Adult-Oriented Business shall not be displayed or exhibited in a manner which exposes to public view any pictures or illustrations depicting any "specified sexual activity" or any "specified anatomical area." Materials offered for sale or viewing at any AdultOriented Business shall not be displayed or exhibited in a manner which exposes any depiction of any "specified sexual activity" or any "specific anatomical area" to the view of persons outside the building or off the premises on which such Adult-Oriented Business is located.

F. Restrictions Cumulative. The restrictions set forth in this chapter are in addition to any other applicable provision of this code. In event of any conflict between any such provisions, the more restrictive shall apply.

(O2003 12)

\subsubsection{Agricultural Buffers.}

A. Specific Purpose. The specific purpose of these regulations is to minimize potential conflicts between agricultural and urban residential uses by providing appropriate agricultural buffer areas, thereby protecting the health, safety and welfare of the residents of the City and contributing to the long-term preservation and maintenance of agricultural activities in Napa County.

B. Required Provisions. Except as provided in subsection E of this section, the following provisions shall be required for all residentially zoned lots adjacent to the Rural Urban Limit (RUL) line when development is proposed.

1. An agricultural buffer plan to address the following requirements:

a. Setback: A special agricultural setback of between 80 and 120 feet wide between any dwellings or other buildings designed for human habitation and the nearest residential property line(s) adjoining the RUL. The exact distance shall be based on the overall density of the proposed residential project as follows:

$>0-6$ units/acre $=80$ foot setback

$>6-10$ units/acre $=100$ foot setback

$>10$ units/acre $=120$ foot setback

Within the special agricultural setback, a permanent landscape buffer area at least 20 feet wide measured from the residential property line(s) adjoining the RUL and nearest agricultural property line(s) shall provide a clear boundary between urban and agricultural uses. The landscape buffer shall consist of a mix of trees, shrubs, berms, fences, walls, etc. sufficient to reduce noise, dust and diffuse light and act as a physical separation between the housing and agricultural activities, in a design acceptable to the Planning Commission (or Community Development Director in the case of single-family dwellings exempt from Planning Commission review). Final landscape plans shall specify that all plant materials be certified by the Napa County Agricultural Commissioner inspection program for freedom from the glassy winged sharpshooter or other pests. Except for buffer fences and walls, pump stations or similar improvements, no accessory structures shall be located within the landscape buffer area. The permanence of the landscape buffer shall be assured through appropriate easements or equally effective 
restrictions, and ongoing maintenance and funding mechanisms

b. Noise. Sound/noise reducing design and construction techniques (e.g. window-door orientation, use of double pane windows, etc.) to reduce interior noise levels from adjoining farm operations to acceptable levels as defined in the noise element of the general plan;

c. Covenant: A recorded covenant (to run with the land) that the property may be subjected to inconveniences or discomfort arising from agricultural operations. Such discomfort or inconveniences may include, but are not limited to: noise, odors, dust, chemicals, smoke, pests, spraying operation of machinery during any 24-hour period, aircraft operation, and other potential nuisance problems associated with normal agricultural practices of adjoining properties. One or more of the inconveniences described above may occur even in the case of agricultural operations that are in conformance with existing laws and regulations and locally accepted customs and standards. The covenant shall also state that the farmer/grower/rancher has the right to farm and the adjoining property owner may not sue to prevent such activities normally associated with agricultural activities. For rental properties, the property owner shall agree to notify tenants of right to farm provisions as part of subsequent rental agreements;

d. Site design. A project layout with streets that do not end at the RUL, to preclude a future extension into unincorporated areas outside the RUL.

C. Submittal Requirements. The agricultural buffer plan shall be drawn to scale, be of sufficient clarity to indicate the nature and extent of proposed work including timing or phasing, and include the following information:

1. Name and address of owner.

2. Name, address, professional status, license number, and phone number of the person who prepared the plan.

3. Location and assessor's parcel number of the proposed site.

4. North arrow, scale, and the name and location of the nearest public road intersection.

5. Site plan showing special agricultural buffer in relation to property line(s) adjacent to the RUL line, adjacent property line(s), public streets and other features such as creeks or rivers, and lot(s), building envelopes and/or proposed buildings.

6. Plans. Detailed construction plans showing how the project complies with the requirements of an agricultural buffer plan including but not limited to building materials, construction techniques and landscaping.

7. Summary: A summary discussion of site design and proposed measures to mitigate the agricultural-urban residential land use conflicts including setbacks, landscaping, grading and special construction techniques, etc.

D. Conditions of Approval. All approved agricultural buffer measures to mitigate agricultural-urban residential land use conflicts shall become conditions of approval of the project.

E. Waivers.

1. The Planning Commission (or Community Development Director in the case of single-family dwellings which are exempt from review by the Planning Commission) may, after consultation with the Agricultural Commissioner, waive the requirement for an agricultural buffer plan for projects where it can be clearly demonstrated that no agricultural-urban residential land use conflicts will result from the development of the property or where the requirement for an agricultural buffer plan meeting the above requirements would preclude the use of the property. An applicant requesting such a waiver shall submit sufficient information to substantiate the waiver.

2. The Planning Commission (or Community Development Director in the case of single-family dwellings which are exempt from review by the 
Planning Commission) may, after consultation with the Agricultural Commissioner, also modify or substitute different requirements than those identified above for developments on a project specific basis if in their opinion different requirements will achieve the intended purpose of this section. In particular, the agricultural setback between any dwellings or other buildings designed for human habitation and the nearest residential property line(s) adjoining the RUL may be reduced where off-site roads, creeks or rivers provide additional setback distance between residential uses and agricultural activities.

3. Further, the requirements of this section are waived for construction within an existing dwelling involving no expansion.

(O2003 12)

\subsubsection{Agricultural Cultivation and Animal Keeping.}

A. Purpose. To provide for a range of accessory agricultural activities and maintenance of livestock on larger residentially-zoned properties within the City while minimizing impacts to surrounding properties. (Resource Area properties are subject to requirements of that district).

B. Required Provisions.

An Administrative Permit is required for agricultural cultivation or animal keeping.

"Agricultural cultivation" subject to these provisions shall include cultivation of more than $1 / 2$ acre of land for viticulture, horticulture or similar intensive farming initiated after the effective date of this ordinance.

"Agricultural animal keeping" for purposes of this section includes the raising of listed animals, birds or bees for personal or commercial use.

C. Standards.

1. Properties must be 1 acre in size or larger to incorporate such uses.

2. The following performance standards shall apply to the keeping of one or more horse, mule, donkey, cow, steer, goat, pig, sheep, duck, turkey; or the keeping of bees or fifteen or more chickens, rabbits, and similar small animals, but specifically excluding roosters, peacocks, guinea hens or geese prohibited by NMC 6.04.070.

a. Not more than one horse, mule, donkey, cow, steer, goat, pig or sheep shall be kept for each $1 / 2$ acre of lot area;

b. The closest point of any structure or fenced pasture where the animal(s) or bees are to be kept is 40 feet distant from any dwelling on an adjacent lot.

3. Animals, bees, birds listed in C.2 above are subject to individual case review, and may be subject to the following types of standards:

a. Requirements for fences or fenced stockade areas; requirements regarding provision of food and water supply, such as supply locations, requirements for closed, rodent-proof containers, etc.;

b. Requirements to secure or shelter animals at night to minimize possible noise impacts;

c. Requirements to maintain sanitary conditions by regular cleanup;

d. Limits on numbers of apiaries, animals;

e. Notice that the premises where the animal(s) is to be kept may require inspection by the County Agricultural Commissioner;

f. On :HS Hillside sites or other sensitive sites adjacent to watercourses or including wetlands, landscaped buffer areas and erosion control plans or other measures may be required to address environmental concerns. In approving the application, the Community Development Director may impose conditions deemed necessary to assure that the keeping of agricultural animals will not result in an adverse effect on the health, sanitation, safety or welfare of area residents or harm the environment. 
4. Cultivated agriculture activities shall require a grading and erosion control plan; notification to the Agricultural Commissioner, and, for development near watercourses or wetlands, notification to the Department of Fish and Game and/or Corps of Engineers, and consultation with the City's water division to address efficient use of water. The Community Development Director may impose conditions deemed necessary to assure that the cultivated agricultural activities will not result in an adverse effect on the health, sanitation, safety or welfare of area residents or harm the environment.

(O2003 12)

\subsubsection{Bed and Breakfast Inns.}

A. Purposes. The specific purposes of these standards are:

1. To assist in preservation and adaptive reuse of City historic resources.

2. To serve visitors to the Napa Valley.

3. To assure compatibility with residential neighborhood surroundings.

4. To mitigate impacts on local rental housing stock, to the extent permitted by State law.

B. Use Permit Required. Bed and breakfast inns may be established with a Use Permit in buildings designated as being of historic and/or architectural significance on the City's Historic Resources Inventory, or through a subsequent historic survey.

C. Standards. The following standards shall apply to the establishment of the bed and breakfast inn:

1. Onsite owner/manager: The building must be the primary residence of the owner or manager of the bed and breakfast use; and

2. Location and size: Principal and accessory buildings may be used for bed and breakfast guest rooms. The majority of the guest rooms shall be in the principal building. Additions to either the principal building or accessory buildings shall be visually subordinate to the principal building. New accessory buildings are not encouraged, but may be acceptable if the applicant provides evidence and the city finds that there is no economically feasible way to restore the principal building without new accessory buildings. A waiver to the standard that the majority of the guest rooms shall be in the principal building may be requested for buildings over 3,000 sq. $\mathrm{ft}$. if the applicant can provide evidence and the city finds that there is no economically feasible way to restore the building without the additional rooms.

3. Meals: There shall be only 1 meal, breakfast, served daily and limited to guests and owner/manager of the bed and breakfast inn.

4. Parking: One parking space shall be provided for the owner/manager's unit and each guest room. On-site parking shall be designed and located to not detract from the residential and historic character of the site's buildings and grounds. Credit may be given in limited instances for on-street parking fronting the structure where a survey documents such parking is available and does not affect adjacent residential uses.

5. Signs: Signs shall be limited to two square feet attached directly to the residential building or structure, unless a sign permit is obtained.

6. Number of Guest Rooms: The number of guest rooms permitted will be determined based on the size of the existing building, grounds and site; the relationship of the site to the character, size and scale of surrounding neighborhood buildings; and visitor access and parking. In general, the number of guest rooms should not exceed 10.

7. Concentration of Inns: When a new B\&B is proposed within 300 feet of another $\mathrm{B} \& \mathrm{~B}$, the decision-making body shall additionally find that the new B\&B doesn't harm the character and livability of adjacent residential properties. 


\section{Appendix E}

\section{San Luis Obispo County, CA}

Agriculture and Open Space Element of the General Plan - Goals, Policies and Implementation for Agricultural Buffers

Appendix D of the Agriculture and Open Space Element - Agricultural Buffer Policies

San Luis Obispo Department of Agriculture - Agricultural Buffer Policies and Procedures 


\section{AGRICULTURAL GOALS, POLICIES, IMPLEMENTATION MEASURES AND PROGRAMS}

\section{INTENT}

Through the following goals, policies, implementation measures and programs, it is the intent of San Luis Obispo County to promote and protect the agricultural industry of the County, to provide for a continuing sound and healthy agriculture in the county, and to encourage a productive and profitable agricultural industry. This can be done by:

1. Supporting increased sales of crops and livestock products produced by farmers, ranchers and processors of food, fiber and flowers in this county;

2. Supporting the efforts of the county's agricultural industry in developing and enhancing domestic and international markets for San Luis Obispo County products;

3. Supporting the creation of value added products and the development of new consumer products; and

4. Supporting long-term productivity and sustainability of the county's farms and ranches by conserving and protecting the soil, water and air which are agriculture's basic resources.

This chapter focuses on the agricultural resources of the county while recognizing that other valuable open space resources such as wetlands, riparian vegetation, or scenic resources can exist on those agricultural lands. Therefore, the goals, policies and implementation measures in this chapter address agriculture first, but also address the protection of open space resources on private lands designated Agriculture by the LUE and this element and on other lands used for production agriculture. Open space resources found on public lands and private non-agricultural lands are addressed in chapter 3, The Open Space Element.

\section{AGRICULTURAL GOALS (AG)}

\section{AG1: Support County Agricultural Production.}

a. Support and promote a healthy and competitive agricultural industry whose products are recognized in national and international markets as being produced in San Luis Obispo County.

b. Facilitate agricultural production by allowing a broad range of uses and agricultural support services to be consistently and accessibly located in areas of prime agricultural activity. 
c. Support ongoing efforts by the agricultural community to develop new techniques and new practices.

d. Develop agricultural permit processing procedures that are rapid and efficient. Do not require permits for agricultural practices and improvements that are currently exempt. Keep the required level of permit processing for non-exempt projects at the lowest possible level consistent with the protection of agricultural resources and sensitive habitats.

\section{AG2: Conserve Agricultural Resources.}

a. Maintain the agricultural land base of the county by clearly defining and identifying productive agricultural lands for long-term protection.

b. Conserve the soil and water that are the vital components necessary for a successful agricultural industry in this county.

c. Establish land-use policies in this element that support the needs of agriculture without impeding its long-term viability.

AG3: Protect Agricultural Lands.

a. Establish criteria in this element for agricultural land divisions that will promote the long-term viability of agriculture.

b. Maintain and protect agricultural lands from inappropriate conversion to non-agricultural uses. Establish criteria in this element and corresponding changes in the Land Use Element and Land Use Ordinance for when it is appropriate to convert land from agricultural to non-agricultural designations.

c. Maintain and strengthen the county's agricultural preserve program (Williamson Act) as an effective means for long-term agricultural land preservation.

d. Provide incentives for landowners to maintain land in productive agricultural uses. 


\section{AG4: Encourage Public Education and Participation.}

a. Encourage ongoing public education programs by such organizations as the County Department of Agriculture, U.C. Cooperative Extension, Farm Bureau and industry organizations, to provide information about agriculture in San Luis Obispo County and help the public better understand the importance of the agricultural industry.

b. Encourage public participation through the public hearing process in the on-going development of county plans, policies, and ordinances affecting agricultural lands. Utilize the resources of such organizations as the County Agricultural Liaison Board, community advisory groups, and conservation organizations.

\section{AGRICULTURAL POLICIES (AGP)}

The policies to attain the preceding goals are interrelated, therefore, they are addressed under the following headings: use of agricultural lands; resource conservation and management; protection of agricultural lands; and protection of open space resources on agricultural lands. These policies apply primarily to land designated Agriculture on the land use designations map in this element, unless otherwise specified. The policies are intended to be consistent with adopted policies, standards and ordinances of the Local Coastal Program (LCP) and are in addition to all applicable LCP policies, standards and ordinances.

To the maximum extent possible, the following policies, implementation measures and programs try to balance protection of open space resources and the needs of production agriculture, and minimize the impacts to ongoing production agriculture. It is the intent to not require permits for agriculturally-related projects that are currently exempt, and to keep the required level of permit processing for non-exempt projects at the lowest possible level consistent with the protection of agricultural resources and sensitive habitats. The policies and recommended implementation measures apply to discretionary land use permits for new development (see Glossary for definition of development) and proposed land divisions. 
Long-term Conservation Lease. Where agricultural lands also contain open space resources that are worthy of protection, such as riparian habitat, scenic qualities, etc., but the land owner is not interested in selling the property or the development rights, an alternate approach may be to enter into long-term conservation leases. Similar to the provisions of a Williamson Act contract, such a lease could offer protection of the resources for an extended period of time, while also offering the property owner a revenue stream that will enable maintenance of the agricultural activities. The lease could be held by a conservation organization, with the term of the lease automatically renewed annually for another year similar to a Williamson Act contract. This, and other creative methods of resource conservation, should be explored more fully.

\section{Implementation:}

1. The Department of Planning and Building, in cooperation with the county Agriculture Department and U.C. Cooperative Extension, should assist agricultural and conservation organizations in developing and implementing programs to conserve agricultural land. The agencies should prepare a public information brochure for distribution to the agricultural community making them aware of the advantages of participating in such programs.

Timeframe: 12 months from plan adoption.

2. In cooperation and coordination with conservation organizations and other jurisdictions, the county should explore the possibility of establishing a program to protect agricultural lands by purchasing development rights and conservation easements from willing sellers, by offering long-term conservation easements, or through other innovative programs.

Timeframe: To be determined by Board of Supervisors after plan adoption.

3. The County should actively pursue grant funds under provisions of the Agricultural Land Stewardship Program Act of 1995, to assist with the implementation measures contained in this Agriculture and Open Space Element.

Timeframe: Ongoing after plan adoption.

\section{AGP17: Agricultural Buffers.}

a. Protect land designated Agriculture and other lands in production agriculture by using natural or man-made buffers where adjacent to non-agricultural land uses in accordance with the agricultural buffer policies adopted by the Board of Supervisor (see Appendix D). 
Discussion: New residential and other non-agricultural uses that are proposed adjacent to agricultural land or uses may result in land use conflicts. Residential and other nonagricultural uses can be adversely affected by odors, noise, dust and pesticide use. Farmers and ranchers are affected by resident complaints and lawsuits, pilferage of vegetables and fruits, increased incidence of trespass, theft and vandalism, disturbance of livestock by dogs and people, introduction of plant and animal pests and diseases harmful to agricultural uses, increased potential for fire on dry farm and grazing lands, and competition for available water resources.

The LUO contains a number of location and setback standards to separate existing residential areas and uses from potentially incompatible agricultural uses such as feedlots, poultry ranches, or hog farms. In addition, the Board of Supervisors has adopted policies for establishing buffers between agricultural areas and non-agricultural development in order to minimize possible land use conflicts. A further modification to those policies should be considered that would include a provision for public disclosure that a buffer has been applied to a property as part of the county's approval of a discretionary land use permit. The disclosure would provide notice to prospective buyers and sellers that such a restriction applies.

\section{Implementation:}

1. The County Department of Agriculture shall review applications for land division, lot line adjustments, land use permits and proposed general plan amendments for consistency with the agricultural buffer policies adopted by the Board of Supervisors (see Appendix D).

Timeframe: Ongoing.

2. The Department of Planning and Building, the County Department of Agriculture, and agricultural industry groups should develop proposed amendments to the Agricultural Buffer Policy establishing a disclosure process (similar to that found in the Right-to-Farm Ordinance, Title 5 of the County Code) that would inform potential buyers and sellers of properties that, as part of the county's approval of a discretionary land use permit, an agricultural buffer has been applied to a property.

Timeframe: 24 months from plan adoption. 


\section{APPENDIX D: AGRICULTURAL BUFFER POLICIES}

The following ag buffer policies have been adopted by the Board of Supervisors.

\section{$\underline{\text { Policy Statement }}$}

It is the policy of the Agricultural Commissioner through the county's land use planning programs to:

1. Promote and protect agriculture

2. Protect the public's health and safety

3. Provide the Board of Supervisors and City Councils with technical information and assistance in dealing with land use compatibility and capability issues affecting agriculture.

This is accomplished through the review of certain land use proposals in/or near agricultural areas and providing recommended mitigational measures where necessary.

\section{Objectives}

1. The department will make a determination of "significant land use conflict" on project referrals. The basis for the determination will also be provided.

2. Recommended mitigation measures will be provided if a significant land use conflict determination is made.

\section{$\underline{\text { Land Use Compatibility Issues and Mitigation Benefits }}$}

1. Pesticide Use
A. Provides for a margin of safety for the public and sensitive non-target areas.
B. Reduces the need for spray buffers or other governmental restrictions which negatively impact agriculture.
C. Helps maintain the feasibility of pesticide use as an alternative for sustainable agriculture.


2. Noise
A. Reduces the potential for nuisance from a variety of agricultural sources such as bird frightening devices, pumps, heavy equipment, wind machines, etc.
B. Reduces local neighbor conflict and complaints to governmental agencies.
C. Reduces the disturbance from noise and light associated with night harvesting.

3. Dust

A. Creates distance or screening for dust to settle out before affecting homes or people.

4. Trespass/Vandalism/Theft/Litter/Liability

A. Helps reduce the potential negative impact that people and pets can have on agricultural property.

5. Rodent Control

A. Helps maintain the use of agricultural rodent control materials which may be otherwise prohibited in close proximity to homes, schools, and other urban areas.

B. Reduces the likelihood of accidental poisoning of pets.

6. Agricultural Burns

A. Helps maintain agricultural burning as a cultural management tool. Otherwise, burns may be prohibited or further regulated if dwellings are built too close to agricultural property.

B. Protects the public's health and safety.

7. Beekeepers

A. Helps preserve the use of bees for honey production and pollination. Otherwise, beekeepers may be forced to move hive sets out of agricultural areas due to close proximity to urban areas.

B. Protects the publics health and safety from bees searching for food and water.

8. Erosion and Development

A. Reduces the sources of soil erosion in agricultural areas.

B. Reduces impacts on agriculture from flooding and siltation. 
9. Other sources of land use conflict unique to certain situations.

\section{$\underline{\text { Referral Process }}$}

1. The Agricultural Commissioner's office responds to referrals sent by the Environmental Coordinator's Office, Planning Department, or city government. Issues usually relate to proposed development, land divisions, zoning or general plan changes adjacent to or in the vicinity of existing agricultural land use. Responses are in writing and advisory only.

2. An on-site evaluation is conducted usually with the applicant and/or agent. Nearby agricultural operators are contacted whenever possible.

3. Existing agricultural use, within an appropriate range, is evaluated for potential significant land use conflict with the proposal. Realistic future agricultural uses on agricultural zoned parcels may also be considered.

4. Buffer determinations and other mitigation measures are made on a case by case basis considering all relevant factors. County wide standard or minimum setback distances are not used. However, this procedural guideline is followed to provide for maximum consistency.

5. Recommended mitigation measures are subject to review and modification by our staff as long as the margin of safety is maintained, potential nuisance issues are adequately addressed and potential land use conflict is maintained at a level below significance.

6. Agricultural Commissioner land use reports will also identify potential land use conflicts and negative impacts to agriculture in situations which may be partially or not at all mitigated. Even with buffer setbacks, etc., agriculturalists may be further restricted in their production practices or experience losses due to adjacent development.

7. Agricultural Commissioner's staff is available for testimony at public hearings upon the request of the Board of Supervisors, Planning Department, Environmental Coordinator, or city government.

\section{$\underline{\text { Procedural Guidelines }}$}

Introduction

Type and extent of agricultural use, zoning, site specific non-crop factors, and the nature of the land use proposal are the most significant factors in a determination of significant land use conflict and subsequent mitigation measures. 
1. Agricultural Use

A. Extent: An evaluation is made if existing agricultural use is of a "production agriculture" scope. This differentiates "hobby farms", "ranchettes", or other smaller non-commercial type agricultural uses.

B. Type: Farming practices vary considerably by type of agricultural use. Subsequently, land use conflict determinations and recommended mitigation measures are often directly related to the type of agricultural use potentially impacted by the referred land use proposal.

C. Historical/Current/Future: An evaluation may be made concerning the suitability of a particular parcel or area for certain types of agricultural uses.

2. Zoning

Zoning on agricultural use parcels adjacent/near the referred land use proposal are evaluated. The zoning of the referred parcels and the overall zoning of the area may also be evaluated.

A. Parcels adjacent to the referral project, zoned agriculture, with an existing or realistic future agricultural use normally provides a basis for a land use conflict determination and subsequent mitigation measures.

B. Parcels adjacent to the referral project zoned for development (anything other than agriculture or open space) may provide a basis for a land use conflict determination only if a "production agriculture" use exists at the time of evaluation.

3. Site Specific Non-Crop Factors

Various site specific factors are evaluated and potentially utilized in land use conflict determinations and mitigation measures. These include, but are not limited to: topography, prevailing wind direction, natural screening (e.g.; vegetation, stream channels), soil type, and the extent of existing development.

4. Nature of the Proposal

Specific factors related to the referred land use proposal that may be significant include, but are not limited to: parcel size, configuration, density of development, and intended type of land use. 


\section{$\underline{\text { Mitigation Measures }}$}

\section{Objective}

Building setbacks (buffers) and/or screening techniques (walls, landscaping, etc.), are useful to increase the likelihood of compatibility between development (homes, schools, etc.) and agricultural property. Buffers are the most effective mitigation measure.

\section{Scope}

Building setbacks specify distance between agricultural property and future building sites. The buffer will allow for such land uses as landscaping, barns, storage buildings, orchards, pastures, etc., while protecting the agricultural use and the public's health and safety.

The County does not have the authority to restrict the agricultural land use in order to accomplish the recommended buffer. However, the Agricultural Commissioner does have the authority, and has at times, imposed spray buffers and other restrictions to pest management practices due to development or other potential hazards near agricultural operations.

\section{$\underline{\text { Agricultural Buffer Distance Determinations }}$}

1. General Guidelines

A. Determinations are made based on all relevant site and project criteria, practical knowledge of agricultural practices, technical literature, contact with other professionals within the University, industry, government agencies and training.

B. "Margin of safety" and "probability" concepts are used in determining setback distances.

C. The department's land use reports will identify recommended mitigation measures and will not provide alternatives.

D. Existing dwellings adjacent to agricultural use may already negatively impact agriculture. Buffer mitigations deal with reducing future or additional impacts and aren't necessarily affected by existing dwellings unless the extent of existing development is such that the proposal does not significantly worsen the land use conflict already present.

2. Buffer Distance Ranges by Crop

Agricultural practices associated with the production of crops are the most important contributing factor to land use conflict when development occurs in close 
proximity to agricultural areas. Since production practices vary considerably by type of crop, buffer distances may vary accordingly. Ranges in distance are necessary due to the influence that site or project specific factors may have.

\section{Buffer Distance Range by Crop}

Type of Agricultural Use

Vineyard

Irrigated orchards

Irrigated vegetables and berries

Field Crops

Dry farm almonds

Rangeland/pasture

Wholesale nurseries

Animal Husbandry

\section{Buffer Distance Range}

$400-800$ feet

$300-800$ feet

200 - 500 feet

100 - 400 feet

100 - 200 feet

50 - 200 feet

100 - 500 feet

See L.U.E.

Site specific non-crop factors and proposal specifications often affect the final buffer distance recommendation within the above range. Other mitigation measures such as screening, may also affect buffer distance recommendations. Significant overriding factors could justify buffers outside the indicated range.

3. Buffers and Development Potential

Potential development entitlement on the referred land use proposal will always be considered. However, with certain types of production agricultural crop uses on agricultural zoned land, the analysis may lead to a recommendation to: deny a portion or all of a proposal; redesign the project to mitigate impacts; or project phasing.

\section{Zoning and Buffers}

A. Effect of Agricultural Use Zoning on Project Mitigation.

The zoning on agricultural use parcels adjacent to the proposed land use referral may affect buffer determinations.

The following table applies to the zoning of parcels potentially affected by proposed projects. These parcels usually adjoin the proposed project, but may also encompass other parcels in the nearby area (regional considerations). 


\section{ZONING AND BUFFER RECOMMENDATIONS}

$\underline{\text { Adjacent Parcel }}$

Buffers May Be

Zoning

Ag. Zone

Ag. Zone

Ag. Zone

Non-Ag. Zone Production

Ag. Use

Non-Ag. Zone

Non-Production

Ag. Use

Recommended

Yes

Yes

Yes

Realistic

Future Ag. Use

Yes

No

Development

Entitlement

Possibly Effected

Yes

Non-Ag. Zone Realistic Future

Prod. Ag. Use
Yes

*Yes
No

No

*Production agricultural use parcels in non-agriculturalzones which have historic agricultural value, prime soils, or other unique agricultural characteristics, will receive 8the same level of recommended mitigation protection as do agricultural zoned parcels.

For other production ag use parcels in non-agricultural zones, preferred buffer distances may need to be reduced to allow for potential development entitlement. Factors which then are evaluated to reduce the buffer are: the smallest parcel size entitled by the zoning on the subject property; locating a reasonable building site; or reconfiguration. 
B. Use of Project Mitigation on Agriculturally Zoned Parcels

Buffers will only be recommended on parcels zoned agriculture which are under 20 acres in size (substandard sized lots commonly known as antiquated subdivisions). Maximum appropriate buffer distance within approved ranges will be recommended, but distances may need to be reduced to allow for reasonable home sites on existing parcels.

\section{Specific Situational Issues}

1. When buffers are recommended for proposed land use projects adjacent to production agriculture on non-agriculturally zoned property, the report will normally state: "In the event farming on the adjacent agricultural land use is discontinued in the future, the potential for significant land use conflict may cease and the mitigation measures may not be necessary."

2. Concerning screening, the department will not recommend the specific type of plant material or construction material for a wall or fence, but may state objectives and evaluate the applicants written proposal.

3. Organic farming practices will not typically influence mitigation measures.

4. Proposed industrial land uses adjacent to agricultural areas may also present significant land use conflict. Specific types of industrial use will be evaluated on a case by case basis through the normal referral process.

5. Land use conflict may be significantly reduced if the agricultural use and the proposed use is owned/operated by the same party (eg: Winery or a roadside stand added to an existing agricultural operation.)

6. Home sites that already exist within a "buffer zone" are not effected by the buffer restrictions. Buffers will only effect location of new home sites. Mobile homes are considered home sites and subsequently can be replaced by permanent home construction within the buffer zone. Permanent home replacement (e.g., fire destruction) would also be unaffected by the buffer. 


\title{
COUNTY OF SAN LUIS OBISPO Department of Agriculture/Measurement Standards
}

\author{
2156 SIERRA WAY, SUITE A, SAN LUIS OBISPO, CALIFORNIA 93401-4556 \\ ROBERT F. LILLEY \\ (805) 781-5910 \\ AGRICULTURAL COMMISSIONER/SEALER \\ FAX: (805) 781-1035 \\ AgCommSLO@co.slo.ca.us
}

November 2005

\section{Agricultural Buffer Polices And Procedures}

\section{$\underline{\text { Policy Statement }}$}

It is the policy of the Agricultural Commissioner and Planning Director through the county's Agriculture and Open Space Element to:

1. Promote and protect agriculture

2. Protect the public's health and safety

3. Provide the Board of Supervisors, LAFCO, School Districts, and City Councils with technical information, assistance, and buffer recommendations to address land use compatibility and issues affecting agriculture.

\section{$\underline{\text { Objectives }}$}

The Agricultural Commissioner will evaluate referrals to determine if potential "significant land use conflict" between agricultural lands and non-agricultural lands will occur with the proposed project. The basis for the determination and recommended mitigation measures will be provided in a written report. Determinations and recommendations are advisory and made on a site-specific basis within the established buffer policies and procedures.

\section{Buffers Reduce Land Use Conflict from:}

1. Pesticide Use
A. Provides for a margin of safety for the public and sensitive non-target areas.
B. Reduces the need for spray buffers or other governmental restrictions, which negatively impact agriculture.
C. Helps maintain the feasibility of pesticide use as a tool for agriculture.
D. Reduces local neighbor conflict and complaints to agriculturalist and government agencies.

2. Noise and Night time lighting

A. Reduces the potential for nuisance from a variety of agricultural sources such as bird frightening devices, pumps, heavy equipment, wind machines, etc.

B. Reduces local neighbor conflict and complaints to governmental agencies.

C. Reduces the disturbance from noise and light associated with night harvesting. 
3. Dust

A. Creates distance or screening for dust to settle out before affecting homes or people.

4. Trespass/Vandalism/Theft/Litter/Liability

A. Helps reduce the potential negative impact that people and pets can have on agricultural property.

B. Helps reduce the impact that stray livestock can have on neighbor's property.

\section{Rodent Control}

A. Helps maintain the use of agricultural rodent control materials, which may be otherwise prohibited in close proximity to homes, schools, and other urban areas.

B. Reduces the likelihood of accidental poisoning of pets.

6. Agricultural Burns

A. Helps maintain agricultural burning as a cultural management tool. Otherwise, burns may be prohibited or further regulated if dwellings are built too close to agricultural property.

B. Protects the public's health and safety.

7. Beekeepers

A. Helps preserve the use of bees for honey production and pollination. Otherwise, beekeepers may be forced to move hive sets out of agricultural areas due to close proximity to urban areas.

B. Protects the public's health and safety from bees searching for food and water.

8. Erosion and Development Impacts

A. Reduces the sources of soil erosion in agricultural areas from development activities on adjacent lands.

B. Reduces impacts on agriculture from flooding and siltation.

9. Harborage and introduction of agricultural disease and pests

A. Protects agriculture by reducing the incident of insect and diseases moving from backyard situations to adjacent agriculture.

10. Other sources of land use conflict unique to certain situations. 


\section{$\underline{\text { Referral Process }}$}

1. The Agricultural Commissioner's office responds to referrals sent by the Planning Department, Public Works, LAFCO, School Districts, or city government. Issues usually relate to proposed development, land divisions, lot line adjustments, zoning or general plan changes adjacent to or in the vicinity of existing agricultural land use. Responses are in writing and advisory only.

2. An on-site evaluation shall be conducted with the applicant and/or agent. Nearby agricultural operators are contacted whenever possible.

3. Existing agricultural use, within an appropriate range, is evaluated for potential significant land use conflict with the proposal. Realistic future agricultural uses on agricultural zoned parcels shall also be considered.

4. Buffer determinations and other mitigation measures are made on a case-by-case basis considering established buffer distance ranges and all relevant factors. Countywide standards or minimum setback distances are used only when specified in the LUO. However, this procedural guideline is followed to provide for maximum consistency.

5. Recommended mitigation measures are subject to review and modification by the department as long as the margin of safety is maintained, potential nuisance issues are adequately addressed and potential land use conflict is maintained at a level below significance.

6. Agricultural Commissioner land use reports shall also identify potential land use conflicts and negative impacts to agriculture in situations, which may be partially or not at all mitigated. Even with buffer setbacks, etc., agriculturalists may be further restricted in their production practices or experience losses due to adjacent development.

7. Agricultural Commissioner's staff is available for testimony at public hearings upon the request of the Board of Supervisors, Planning Commission, Subdivision Review Board, Planning and Building Department, LAFCO, or city government. 


\section{$\underline{\text { Procedural Guidelines }}$}

\section{Introduction}

The type and extent of agricultural use, zoning, site specific non-crop factors, and the nature of the land use proposal are the most significant factors in a determination of significant land use conflict and subsequent mitigation measures.

1. Agricultural Use

A. Extent: An evaluation is made if existing agricultural use is of a "production agriculture" scope. This differentiates "hobby farms", "ranchettes", or other smaller non-commercial type agricultural uses.

B. Type: Farming practices vary considerably by type of agricultural use. Subsequently, land use conflict determinations and recommended mitigation measures are often directly related to the type of agricultural use potentially impacted by the referred land use proposal.

C. Historical/Current/Future: An evaluation shall be made concerning the suitability of a particular parcel or area for certain types of agricultural uses.

\section{Zoning}

Zoning on agricultural use parcels adjacent/near the referred land use proposal are evaluated. The zoning of the referred parcels and the overall zoning of the area may also be evaluated. (See Table 2, Page 7)

A. Parcels adjacent to the referral project, zoned agriculture, with an existing or realistic future agricultural use normally provides a basis for a land use conflict determination and subsequent mitigation measures.

B. Parcels adjacent to the referral project not zoned agriculture may provide a basis for a land use conflict determination only if a "production agriculture" use exists at the time of evaluation.

\section{Site Specific Non-Crop Factors}

Various site-specific factors are evaluated and potentially utilized in land use conflict determinations and mitigation measures. These include, but are not limited to: topography, prevailing wind direction, natural screening (e.g.; vegetation, stream channels), soil type, location of existing roads, and the extent of existing development.

\section{Nature of the Proposal}

Specific factors related to the referred land use proposal that may be significant include, but are not limited to: parcel size, configuration, density of development, and intended type of land use. Developments, which include dwellings or schools, may need larger buffers than businesses where the presence of people may be limited. 


\section{$\underline{\text { Mitigation Measures }}$}

\section{Objective}

Building setbacks (buffers) and/or screening techniques (walls, landscaping, etc.), are useful to increase the likelihood of compatibility between development (homes, schools, etc.) and agricultural property. Buffer distances are the most effective mitigation measure.

\section{Scope}

The buffer is placed on the developer's property and will be recorded as a distance from the property line to the proposed occupied structure. However, the total buffer distance calculation and recommendation is measured from proposed occupied structure to the edge of the agricultural operation. The buffer will allow for such land uses as landscaping, barns, storage buildings, orchards, pastures, etc., while protecting the agricultural use and the public's health and safety.

The County does not have the authority to restrict the agricultural land use in order to accomplish the recommended buffer. However, the Agricultural Commissioner does have the authority, and has at times, imposed spray buffers and other restrictions to pest management practices due to development or other potential hazards near agricultural operations.

\section{$\underline{\text { Agricultural Buffer Distance Determinations }}$}

1. General Guidelines

A. Determinations are made within this policy based on all relevant site and project criteria, practical knowledge of agricultural practices, technical literature, contact with other professionals within the University, industry, government agencies and training.

B. "Margin of safety" and "probability" concepts are used in determining setback distances.

C. The department's land use reports will identify recommended mitigation measures and will not provide alternatives.

D. Existing dwellings or other development adjacent to agricultural use may already negatively impact agriculture. Buffer mitigations address reducing future or additional impacts and aren't necessarily affected by existing dwellings unless the extent of existing development is such that the proposal does not significantly worsen the land use conflict already present.

2. Buffer Distance Ranges by Crop

Agricultural practices associated with the production of crops are the most important contributing factor to land use conflict when development occurs in close proximity to agricultural areas. Since production practices vary considerably by 
type of crop, buffer distances may vary accordingly. Ranges in distance are necessary due to the influence that site or project specific factors may have.

\section{Buffer Distance Range by Crop}

Table 1

Type of Agricultural Use

Buffer Distance Range

1. Intensive Agricultural Uses

Vineyards

$200-600$ feet

Irrigated orchards

200 - 600 feet

Irrigated vegetables and berries

200 - 600 feet

Irrigated Forage and Field Crops

100 - 400 feet

Wholesale nurseries - Outdoors

100 - 500 feet

Greenhouses

100 - 300 feet

2. Non-Intensive Agricultural Uses

Dry farm field crops, orchards and vineyards $\quad 100$ - 200 feet

Rangeland/pasture

50 - 200 feet

Site-specific non-crop factors (such as topography, prevailing wind direction, and elevation differences) and proposal specifications often affect the final buffer distance recommendation within the ranges listed above in Number 1 and 2. Significant overriding factors or land unsuitable for agricultural use could justify recorded buffers less than the indicated range.

3. Buffers and Development Potential

Potential development on the referred land use proposal will always be considered. However, with certain types of production agricultural crop uses as defined in Table 2 below on agricultural zoned land, the analysis may lead to a recommendation to alter the project.

4. Zoning and Buffers

A. Affect of Agricultural Use Zoning on Project Mitigation.

The zoning on agricultural use parcels adjacent to the proposed land use referral may affect buffer determinations.

The following table applies to the zoning of parcels potentially affected by proposed projects. These parcels usually adjoin the proposed project, but may also encompass other parcels in the nearby area (regional considerations). 
Zoning and Buffer Recommendations

Table 2

\begin{tabular}{|lllc|}
\hline \multicolumn{2}{|c|}{ Adjacent Parcel } & \multicolumn{1}{c|}{$\begin{array}{c}\text { Project Parcel } \\
\text { Mitigation }\end{array}$} \\
\hline Zoning & Ag Use & $\begin{array}{l}\text { Buffers May Be } \\
\text { Recommended }\end{array}$ & $\begin{array}{l}\text { Proposed Development } \\
\text { Possibly Affected }\end{array}$ \\
\hline Ag. Zone & Production Ag. Use & Yes & Yes \\
Ag. Zone & Prime Soils & Yes & Yes \\
Ag. Zone & Realistic Future Ag. Use & Yes & No \\
Non-Ag. Zone & Production Ag. Use & Yes & $*$ Yes \\
Non-Ag. Zone & Non-production Ag. Use & No & No \\
Non-Ag. Zone & Realistic Future & No & No \\
& Production Ag. Use & & \\
\hline
\end{tabular}

*Production agricultural use parcels in non-agricultural zones which have historic agricultural value, prime soils, or other unique agricultural characteristics, will receive the same level of recommended mitigation protection as do agricultural zoned parcels.

B. Use of Project Mitigation on Agriculturally Zoned Parcels

Typically, buffers are not necessary on parcels zoned agriculture. However, buffers will be recommended on parcels zoned agriculture which are under 20 acres in size (substandard sized lots commonly known as antiquated subdivisions). Maximum appropriate buffer distance within approved ranges will be recommended, but distances may need to be reduced to allow for reasonable home sites on existing parcels. 


\section{$\underline{\text { Specific Situational Issues }}$}

1. When buffers are recommended for proposed land use projects adjacent to production agriculture on non-agriculturally zoned property, the report will normally state: The buffer shall become null and void if future development on adjacent parcel(s) precludes production agriculture." Such a determination shall be made in consultation with the Department of Agriculture.

2. The Agricultural Commissioner will not recommend the specific type of plant material or construction material for a wall or fence for screening purposes, but may state objectives and evaluate the applicants written proposal.

3. Organic farming practices will not typically influence mitigation measures.

4. Proposed industrial land uses adjacent to agricultural areas may also present significant land use conflict. Specific types of industrial use will be evaluated on a case-by-case basis through the normal referral process.

5. Land use conflict may be significantly reduced if the agricultural use and the proposed use is owned/operated by the same party (e.g., winery or a roadside stand added to an existing agricultural operation.)

6. Occupied structure(s) that already exist within a "buffer zone" are not affected by the buffer restrictions. Buffers will only affect the location of proposed occupied structures. Mobile homes are considered home sites and subsequently can be replaced by permanent home construction within the buffer zone. Permanent home replacement (e.g., fire destruction) would also be unaffected by the buffer.

\section{$\underline{\text { Disclosure }}$}

The agricultural buffer document will be duly recorded in the chain of title of the subject property. 


\section{Appendix F \\ Stanislaus County, CA \\ Agriculture Element of the General Plan}

Appendix A of the General Plan - Stanislaus County Agricultural Buffer \& Setback Guidelines 


\section{Agricultural Element}

\section{Chapter 7}

\section{AGRICULTURAL ELEMENT}

Agriculture is the leading industry in Stanislaus County generating an annual gross agricultural value in excess of a billion dollars into the local economy. This initial value of farm production has a ripple, or multiplier, effect in the economy by generating related activities such as food processing, retail and wholesale trade, marketing, transportation, and related services. Located in the Central Valley, which has long been known as California's agricultural heartland, Stanislaus County consistently ranks among the top ten agricultural counties in the state. Stanislaus County also plays a major role in agriculture at the national level, based on market value of agricultural product sold.

The success of agriculture in Stanislaus County is largely due to our favorable climate and the flat, fertile soils that comprise the resource base of our biggest industry. The availability of affordable, high quality irrigation water and low-cost electrical power also gives local agriculture a competitive advantage. Agriculture in Stanislaus County is characterized by a broad diversity of commodities. While overall production trends for leading commodities have continued to grow, these trends are not always reflective of the overall health of agriculture in Stanislaus County.

The same elements that make Stanislaus County so well suited for agriculture - favorable climate, flat land, available water and low-cost power - also make the County attractive for urban development. Like other areas of the Central Valley, the County has become a magnet for those in search of affordable housing within commuting distance of the San Francisco Bay Area and other major employment centers.

Confronted with unprecedented population growth, diminishing agricultural resources, and increased production costs, it can no longer be assumed local agriculture will always be a major supplier to the nation with fresh fruits and vegetables and remain the mainstay of our economy. The challenge of solving the problems confronting agriculture in Stanislaus County requires the coordinated efforts of both government and private citizens. The goals to sustain a healthy agricultural economy, conserve our agricultural land, and protect our natural resources are goals for which our community as a whole can strive, from which our community as a whole will benefit.

\section{Purpose}

The purpose of the Agricultural Element is to promote and protect local agriculture through the adoption of policies designed to achieve three main goals:

1. Strengthen the agricultural sector of our economy.

2. Conserve our agricultural lands for agricultural uses.

3. Protect the natural resources that sustain agriculture in Stanislaus County.

The policies are intended to provide clear guidelines for County decision-making. The policies also are intended to express the County's commitment to specific programs and strategies that will ensure the continued success of our agricultural industry and productivity of our agricultural lands. 


\section{Focus}

The overall focus of the Agricultural Element is on the mitigation of negative economic and environmental impacts to agricultural land and the natural resources needed to support local agriculture. The Agricultural Element establishes policies to protect the economy of Stanislaus County by minimizing conflicts between agriculture, the environment, and urban development. By minimizing the impacts of urbanization on agriculture, the County will help protect local agriculture and ensure its continued success.

\section{Scope}

This document represents a broad-based effort to analyze the status of local agriculture, address agricultural issues, consolidate existing County policies and propose strategies to solve problems that exist. Not limited to land use issues, this document goes beyond the scope of most agricultural elements to include strategies for economic development and resource protection related to agriculture. Because of its comprehensive approach, this document can be considered a strategic plan for agriculture in Stanislaus County.

\section{Authority \& Relationship to Other General Plan Elements}

In recognition of the importance of agriculture to our local economy, the Stanislaus County General Plan includes an Agricultural Element to promote and protect local agriculture. Under Section 65303 of the California Government Code, optional elements of the General Plan, are authorized but not mandated by the state legislature. The Agricultural Element is coordinated with several other elements of the General Plan and must be consistent with the entire General Plan. It interacts primarily with agriculture-related policies of the Land Use, Conservation/Open Space, and Housing Elements. To avoid duplication, policies in these elements that affect or relate to agriculture are not repeated in this element. However, such policies are cross-referenced whenever appropriate. The policies in this document have the same legal status as any state-mandated element of the general plan.

\section{Review Period}

The adoption of the Agricultural Element reflects the County's commitment for a strong agricultural economy. As a means of insuring the goals, objectives, policies, and implementation measures of this document remain relevant to the needs of local agriculture, periodic review of the this document is required. Adoption of this document includes a commitment to reviewing it every five years. Reviews shall be conducted by the Agricultural Advisory Board with assistance from both the County Agricultural Commissioners Office and the Planning Department. 


\section{GOAL ONE}

Strengthen the agricultural sector of our economy.

Growth in Stanislaus County is both an opportunity for local agriculture and a threat to its stability. There are opportunities to expand markets for local agricultural products and opportunities for the expansion of existing businesses and the formation of new enterprises. However, growth typically results in increased conflicts between farm and non-farm residents as well as contributing to the loss of productive farmland, the deterioration of air quality, increased competition for water supplies and other resource problems.

Goal One addresses these opportunities and threats by presenting strategies for agriculture-related economic development. These strategies include ways to improve marketing and promotion, provide education and technical assistance, minimize conflicts between farm and non-farm residents, provide adequate housing for farm workers, and ensure food safety.

Because many of these issues are not unique to Stanislaus County alone, but involve the entire Central Valley, the close cooperation of local governments through a voluntary multi-county association or confederation is essential for the continued success of agriculture and the health of our regional economy as a whole.

\section{Objective Number 1.1: Enhance the marketing and promotion of agriculture in Stanislaus County}

The ability to market and promote agriculture on both a county-wide and farm level is essential to the success of agriculture in Stanislaus County. Direct marketing is one method farmers can use to gain market control, but for many crops a local infrastructure for marketing and promotion is needed for success. This local infrastructure is comprised of land, services, and the workforce needed for support industries such as food-processors, manufactures, distributers, suppliers, and retailers. A key factor to attracting and retaining the necessary infrastructure includes a strong local focus on economic development.

Stanislaus County plays an active role in economic development through its participation with private industry in efforts to add value to existing local economic development programs. The ability to market the productivity of agriculture in Stanislaus County is essential to the development of the support industry needed to enhance the sales of agricultural products. Marketing boards for the various agricultural commodities grown and raised in Stanislaus County serve as a link between the farmer, processor, and consumer.

Efforts to highlight the rich agricultural heritage of Stanislaus County help to bridge the gap between consumers and farmers by promoting the value of agriculture to the community as a whole. With the increase in population, the majority of Stanislaus County citizens now reside in urban areas. Clearly community education of farming practices and the economic role of agriculture is important to the long-term health of agriculture as an industry in Stanislaus County. Direct marketing provides an opportunity for farmers to deliver their products directly to consumers, while allowing the farmer to maximize revenues. 
The County supports direct marketing opportunities through the permitting of produce stands and produce markets meeting adopted standards and incidental retail sales and tasting rooms in conjunction with authorized agricultural processing facilities in the agricultural zoning district. For many consumers farm-based direct marketing offers them their only physical connection to agriculture. However, to limit the potential for conflict, the county must take measures to insure direct marketing is conducted in a manner which promotes the health, safety, and welfare of both county residents and agricultural business in the county.

In addition to a strong local market, a strong export market for Stanislaus County agricultural products is a key element to sustaining our agricultural economy. Each year an increasing amount of agricultural products grown in and raised in Stanislaus County are shipped worldwide. Economic development efforts assist companies interested in exporting local agricultural products. In addition to local efforts, the County encourages state and federal efforts to expand agricultural export programs.

\section{Policy 1.1}

Efforts to promote the location of new agriculture-related business and industry in Stanislaus County shall be supported.

\section{Implementation Measure}

1. The County shall continue to participate in economic development efforts to bring new agriculture-related business and industry to Stanislaus County

Responsible Departments: Board of Supervisors

\section{Policy 1.2}

The marketing and promotion of local agricultural products shall be encouraged.

\section{Implementation Measures}

1. The County shall continue to implement existing ordinance provisions relating to directmarketing of locally grown produce.

Responsible Departments: Agricultural Commissioner, Department of Environmental Resources, Planning Department, Planning Commission, Board of Supervisors

2. The County shall encourage efforts to establish direct marketing programs and a market identity for Stanislaus County.

Responsible Departments: Planning Department, Chief Executive Office and Board of Supervisors

3. The County shall encourage the presence of agricultural marketing boards in Stanislaus County.

Responsible Departments: Planning Department, Chief Executive Office and Board of Supervisors

\section{Policy 1.3}

Efforts to expand markets for the export of local agricultural products shall be encouraged. 


\section{Implementation Measure}

1. The County shall support and encourage efforts to create and expand export programs which seek to expand markets for commodities produced in Stanislaus County.

Responsible Departments: $\quad$ Agricultural Commissioners Office, Board of Supervisors.

\section{Objective Number 1.2: $\quad$ Support the development of agriculture-related uses}

Given its broad diversity, Stanislaus County agriculture involves a variety of commercial and industrial activities and requires a range of supplies and services. Roadside stands, processing services, maintenance and repair of farm machinery and equipment, custom farming services and similar agriculture-related uses are all important for the success of agriculture.

Some of these activities and support services may be most appropriately located on agricultural lands, where they are convenient and accessible to farmers and ranchers. On the other hand, some of these uses may interfere with agricultural operations. The determination of which commercial activities and support services belong on agricultural lands depends on their connection to agriculture, the potential for conflicts, the size, scale and adaptability of the use, and the amount of land lost to farming.

The A-2 (General Agriculture) zoning district of the County Zoning Ordinance encourages vertical integration of agriculture by organizing uses requiring use permits into three tiers based on the type of uses and their relationship to agriculture. Tier one includes uses closely related to agriculture such as nut hulling and drying, wholesale nurseries, and warehouses for storage of grain and other farm produce grown on-site or in proximity to the site. Tier two includes uses such as agricultural service establishments serving the immediately surrounding area and agricultural processing plants of limited scale. Tier three includes uses that are not directly related to agriculture but may be necessary to serve the A-2 district or difficult to locate in urban areas. Since tier three uses can be people-intensive and thus can adversely impact agriculture, they are generally directed to lands within LAFCO-adopted Spheres of Influence.

Agricultural service establishments designed to serve the immediate area and agricultural processing plants such as wineries and canneries are allowed when the Planning Commission finds that (1) they will not be substantially detrimental to or in conflict with the agricultural use of other property in the vicinity; (2) the establishment as proposed will not create a concentration of commercial and industrial uses in the vicinity; and (3) it is necessary and desirable for such establishment to be located within the agricultural area as opposed to areas zoned commercial or industrial. Limited visitor-serving commercial uses including retail sales, tasting rooms and/or facilities for on-site consumption of agricultural products are allowed in conjunction with agricultural processing facilities.

In general, agricultural service establishments can be difficult to evaluate due to their wide diversity of service types and service areas. This diversity often leads to requests for uses which provide both agricultural and non-agricultural services and/or have a wide-spread service area. Maintaining a focus on production agriculture is key to evaluating agricultural service establishments in the agricultural area. In order to control the scale and intensity of processing facilities, such as wineries and canneries, the County requires such facilities in the agricultural area to show a direct connection to production agriculture in Stanislaus County and applies limitations on the number of employees. 
Visitor-serving commercial uses can be especially problematic. Direct marketing and promotion of local products is beneficial to the agricultural industry, yet the people who come to enjoy the rural setting may interfere with necessary farming practices. This "people versus practice" conflict makes it necessary to limit the location and intensity of visitor-serving commercial uses in agricultural areas.

\section{Policy 1.4}

Limited visitor-serving commercial uses shall be permissible in agricultural areas if they promote agriculture and are secondary and incidental to the area's agricultural production.

\section{Policy 1.5}

Agricultural service establishments shall be permissible in agricultural areas if they are designed to serve production agriculture in the immediately surrounding area as opposed to having a widespread service area, and if they will not be detrimental to agricultural use of other property in the vicinity.

\section{Policy 1.6}

Processing facilities and storage facilities for agricultural products either grown or processed on the site shall be permissible in agricultural areas.

\section{Policy 1.7}

Concentrations of commercial and industrial uses, even if related to surrounding agricultural activities, are detrimental to the primary use of the land for agriculture and shall not be allowed.

\section{Policy 1.8}

To encourage vertical integration of agriculture, the County shall allow research, production, processing, distribution, marketing, and wholesale and limited retail sales of agricultural products in agricultural areas, provided such uses do not interfere with surrounding agricultural operations.

\section{Implementation Measure}

1. The County will continue to implement its existing General Agriculture (A-2) zoning provisions for agriculture-related uses consistent with policies $1.6-1.10$ of the Agricultural Element.

Responsible Departments: Planning Department, Planning Commission, Board of Supervisors

\section{Objective Number 1.3: $\quad$ Minimizing Agricultural Conflicts:}

Urbanization and the proliferation of rural residences throughout the County has led to increased conflicts over agricultural operations. Homeowners complain about noise, odors, flies, chemical spraying and similar impacts of commercial agricultural practices; farmers complain about vandalism, theft and trespassing on farm properties. To minimize these conflicts, the County can implement a variety of tools designed to minimize the interaction between people and agriculture which results in the conflict. These tools include continuing to implement its right-to-farm ordinance, requiring buffers between non-agricultural development and adjacent agricultural operations, and establishing setbacks from agricultural zones. 
Stanislaus County is one of many counties in California to have enacted a right-to-farm ordinance to protect farmers from nuisance suits as a result of normal farming practices. The ordinance requires disclosure to home buyers in farming areas that they are subject to noise, dust, odors, and other impacts of commercial agricultural operations. The ordinance also provides a notification system to make residents more aware of the right-to-farm policy and provides a voluntary agricultural grievance procedure as an alternative to court proceedings.

In practice, the right-to-farm ordinance primarily serves as a tool for making adjacent landowners aware of a right which cannot be fully protected by the ordinance. When faced with non-agricultural development in agricultural areas, farmers often lose their rights to implement normal farming practices, such as spraying, due to the increased risk of exposure to surrounding people. Without question, the right-to-farm ordinance is a critical tool in the effort to protect agricultural land, but beyond awareness it is limited in the true protection it can provide. The success of the right-to-farm ordinance is dependent on supporting policies limiting non-agricultural development in and around agricultural areas.

To lessen the impacts of development by minimizing conflicts between agricultural and nonagricultural uses, buffers should be required when incompatible development is approved in or adjacent to agricultural areas. A buffer is a physical separation such as a topographic feature, a substantial stand of trees, a water course, a landscaped berm or similar feature. Buffers serve as both a physical and visual barrier between agricultural uses and the people in non-agricultural areas. By separating incompatible uses, a buffer minimizes the impacts of non-agricultural development on surrounding agricultural operations and decreases the likelihood of conflict. Buffers are not intended to stop people from entering an area, but rather to limit people as a means of avoiding a situation where conflict is known. Buffers need to take into account 'no spray' policies enforced by the Agricultural Commissioner.

Setbacks from agricultural zones also help minimize conflicts over agricultural practices. For example, standards for residential zones may be amended to require all structures be setback a specified distance from an adjacent agricultural zone. Standards will need to take into account existing residential areas where lots may be too small to accommodate effective setbacks. However, the purpose for adopting setback standards is to insure existing circumstances which have resulted in conflict over agricultural practices are not repeated. As with buffers, setbacks need to take into account 'no spray' policies.

Impacts to agriculture also occur when lands are removed from agricultural production and remain fallow or crops are abandoned. While this type of impact generally occurs on the edge of urban development, it can also occur in the middle of an agricultural area. Fallow and abandoned farmland becomes habitat to invasive and noxious pests which may damage plants, lower production, and cause the need to increase the use of pesticides and rodenticides on adjacent farmland. State law grants authority to the County Agricultural Commissioner to address these type of nuisances, but it ultimately is the responsibility of individual property owners to avoid impacting adjacent farmland.

\section{Policy 1.9}

The County shall continue to protect agricultural resources by limiting the circumstances under which agricultural operations may be deemed to constitute a nuisance.

\section{Implementation Measures}

1. The County shall continue to implement the Right-to-Farm ordinance. Responsible Departments Tax Collector, Clerk Recorder, Planning Department (Planning and Building Permits Divisions), Planning Commission, Board of Supervisors 
2. The County shall utilize complaints related to agricultural activities as educational opportunities.

Responsible Departments: Agricultural Commissioner, Planning Department, Board of Supervisors

\section{Policy 1.10}

The County shall protect agricultural operations from conflicts with non-agricultural uses by requiring buffers between proposed non-agricultural uses and adjacent agricultural operations.

\section{Implementation Measures}

1. The County shall require buffers and setbacks for all discretionary projects introducing or expanding non-agricultural uses in or adjacent to an agricultural area consistent with the guidelines presented in Appendix "A".

Responsible Departments: Planning Department, Agricultural Commissioner, Planning Commission, Board of Supervisors

\section{Policy 1.11}

The County shall support state regulations requiring landowners to manage noxious weeds and pests on fallow or abandoned lands.

\section{Implementation Measure}

1. The Agricultural Commissioner shall enforce state regulations requiring landowners to manage noxious weeds and pests on fallow or abandoned lands.

Responsible Departments: Agricultural Commissioner, Board of Supervisors

\section{Objective Number 1.4: $\quad$ Provide Housing for Farmworkers}

Efficient farm management requires a stable work force to provide labor when needed. To ensure the availability of that labor, adequate numbers of employees must be housed on both a temporary and a permanent basis. Farmworker housing issues involve the location, amount and type of housing for seasonal and year-round farm workers.

State and federal housing programs for farm workers in Stanislaus County are administered by the Stanislaus County Housing Authority, which is an independent public agency entirely separate from County government. Farmworker housing projects currently administered by the Housing Authority are located throughout the County. Other efforts to provide farmworker housing come mainly from individual farmers. The Stanislaus County Department of Environmental Resources is the local agency responsible for enforcing state regulations of farmworker housing.

The County appoints the Housing Authority Board, which is the agency's policy-making body, and otherwise assists the Housing Authority as outlined in a cooperative agreement. The Housing Element of the General Plan includes a commitment that the County shall continue to assist the Housing Authority in its administration of state and federal housing programs for farm workers.

The General Agriculture (A-2) zoning district allows, with use permit, farm labor camps and permanent housing for persons employed on a full-time basis in connection with any agricultural work or place where agricultural work is being performed. The County Zoning Ordinance also recognizes the use of manufactured housing (mobile homes) under a temporary permit when specific criteria can be met to substantiate the need to provide housing for a full-time employee. Manufactured housing (mobile homes) are preferred over standard housing because they can be moved off the property if circumstances change and the employees are no longer needed. 


\section{Policy 1.12}

To help provide a stable work force for agriculture, the County shall continue to facilitate efforts of individuals, private organizations and public agencies to provide safe and adequate housing for farm workers.

\section{Implementation Measures}

1. The County shall continue to implement the farm worker housing policies of the Housing Element of the General Plan. The County also shall facilitate the efforts of other public agencies, private organizations and individuals to provide safe and adequate housing for farm workers.

Responsible Departments: Planning Department, Board of Supervisors

2. The Stanislaus County Department of Environmental Resources shall continue to enforce state regulations regarding farmworker housing.

Responsible Departments: Department of Environmental Resources

3. The County shall consider adoption of expedited permitting procedure for construction of temporary farmworker housing.

Responsible Departments: Department of Environmental Resources, Planning Department, Planning Commission, Board of Supervisors

\section{Policy 1.13}

Temporary housing for full-time farm employees in connection with any agricultural work or place where agricultural work is being performed shall be supported.

\section{Policy 1.14}

Permanent, new housing for seasonal farm workers preferably shall be located in areas supplied with public sewer and water services.

\section{Policy 1.15}

Housing for year-round, full-time farm employees shall be permissible in addition to the number of dwellings normally allowed by the density standard.

\section{Implementation Measure}

1. The County shall continue to implement existing General Agriculture (A-2) zone provisions for farmworker housing consistent with policies 1.16 - 1.18 of the Agricultural Element.

Responsible Departments: Planning Department, Planning Commission, Board of Supervisors

\section{Objective Number 1.5: $\quad$ Support Education and Technical Assistance}

Farmers and ranchers often lack the means to undertake the wide range of activities necessary to pursue new agricultural market opportunities and develop new products. Public educational institutions, including the University of California, California State University Stanislaus, and Modesto Junior College all provide some form of technical assistance to agriculture. However, 
these public institutions can be better utilized to help agricultural groups and individuals conduct market analyses, identify direct marketing opportunities, promote exports, and coordinate other economic development activities in support of local agriculture.

Vocational agriculture programs provide education and hands-on experience for high school and MJC students in Stanislaus County. The 4-H and Future Farmers of America (FFA) programs also play an important role in agricultural education. 4-H programs are part of the U.C. Cooperative Extension, which receives County funding. FFA programs operate in conjunction with vocational agriculture programs in the public high schools and are not directly related to U.C. Cooperative Extension. However, U.C. Cooperative Extension works with vocational agriculture teachers and provides assistance to vocational agriculture programs, both at the high school and the junior college levels.

Several public agencies conduct agricultural research and provide educational services at the County level: the U.S.D.A. Natural Resource Conservation Center, the East and West Stanislaus Resource Conservation Districts, U.C. Cooperative Extension and the Stanislaus County Agricultural Commissioners office. Three of these agencies are centrally located in the County Agricultural Center.

\section{Policy 1.16}

Public education institutions shall be encouraged to provide more technical assistance related to agricultural economic development in Stanislaus County.

\section{Policy 1.17}

The County shall continue to encourage vocational agriculture programs in local high schools and at Modesto Junior College.

\section{Policy 1.18}

Public agencies providing agricultural services shall be encouraged to continue agricultural research and education.

\section{Policy 1.19}

The County shall continue to encourage 4-H and FFA programs for local youth.

\section{Implementation Measures}

1. Local 4-H programs will be encouraged by continued support of U.C. Cooperative Extension.

Responsible Departments: U.C. Cooperative Extension, Agricultural Advisory Board, Board of Supervisors

2. The County will continue to support the County fair, which involves vocational agriculture, FFA and 4-H programs.

Responsible Departments: U.C. Cooperative Extension, Agricultural Advisory Board, Board of Supervisors 


\section{Policy 1.20}

The County shall continue to support the Agricultural Center where offices of public agencies providing agricultural services are centrally located.

\section{Implementation Measure}

1. The County will continue to support the County Agricultural Center that houses the public agencies directly related to agriculture, including the U.C. Cooperative Extension, the Agricultural Commissioner, the U.S. Department of Agriculture, and the California Department of Food and Agriculture.

Responsible Departments: U.C. Cooperative Extension, Agricultural Commissioner, Board of Supervisors

\section{Objective Number 1.6: $\quad$ Protect Food Safety}

The lack of consumer confidence in food can be costly to the agricultural community. The use of chemicals in growing and storing crops, the use of antibiotics and hormones in raising poultry and livestock, and the use of radiation to prolong the shelf-life of our food are types of agricultural practices that worry consumers who are concerned about food safety and its long-term impacts on their health. The public is also concerned about the impact of agricultural chemicals on the environment. Air, soil and water quality problems can result from the unsafe application and disposal of agricultural chemicals. A viable agricultural industry requires a sustainable regulatory framework promoting economic viability and environmental safety.

The primary responsibility for regulating and monitoring the sale and use of pesticides rests with the California Department of Pesticide Regulation, which classifies and registers pesticides, and the Stanislaus County Agricultural Commissioner, who issues permits to possess and use restricted pesticides. In general, no restricted material can be possessed or used in any way until the applicator has obtained a permit from the Agricultural Commissioner. The Agricultural Commissioner also operates programs for the inspection of fruits, vegetables and eggs to ensure quality produce; the inspection of nurseries and seed crops to guard against diseases and inferior plants; pest exclusion to prevent crop-destroying pests from becoming established in California; and pest detection to find pests at the lowest population and in the smallest area possible in order to minimize the effects and costs of an eradication program.

The U.C. Cooperative Extension conducts educational and applied-research programs in integrated pest management and all other aspects of pest control.

\section{Policy 1.21}

The County shall continue to work with local, state and federal agencies to ensure the safety of food produced in Stanislaus County and to maintain a local regulatory framework promoting environmental safety while ensuring the economic viability of agriculture.

\section{Implementation Measures}

1. The Agricultural Commissioner will continue to work with government agencies and farmers to ensure the safe use of agricultural chemicals.

Responsible Departments: Agricultural Commissioner, U.C. Cooperative Extension 
2. The U.C. Cooperative Extension will continue to conduct educational and applied-research programs to promote food safety and agricultural practices that are environmentally sound. Responsible Departments: Agricultural Commissioner, U.C. Cooperative Extension

\section{Objective Number 1.7: $\quad$ Encourage Regional Coordination in the Central Valley}

The Central Valley has long been one of the premier agricultural regions in the world. Yet the Central Valley's population is growing rapidly, resulting in far-reaching demographic, social and economic changes. Some of the most obvious changes include crowded highways, polluted air, and homes and shopping centers sprouting from what used to be farmland. These types of regional impacts will likely have cumulative effects on agriculture, exerting a powerful influence over its future viability in the Central Valley.

One way to address regional impacts of growth and help ensure the continued success of agriculture in the Central Valley is to encourage regional coordination among the various counties and cities in the Central Valley. Currently there are nine councils of government in the Central Valley, including Stanislaus Council of Governments (StanCOG). These groups provide a forum for communication between the County government and municipalities within the County. However, there is no agency that coordinates planning and development activities of counties and cities for the entire Central Valley.

\section{Policy 1.22}

The County shall encourage regional coordination of planning and development activities for the entire Central Valley.

\section{Implementation Measure}

1. The County shall participate in regional efforts to address long-range planning, infrastructure, conservation and economic development issues facing the Central Valley.

Responsible Departments: Board of Supervisors 


\section{GOAL TWO}

Conserve our agricultural lands for agricultural uses.

Agricultural land is a finite, irreplaceable resource. Once agricultural land has been taken out of production and paved over to provide streets for residential subdivisions and parking lots for shopping centers, it is not likely to be farmed again. The urbanization of productive agricultural land means the permanent loss of an irreplaceable resource.

With population in the Central Valley projected to increase dramatically, Stanislaus County faces greater pressure to convert agricultural lands to non-farm residential, commercial and industrial uses. The policies presented in Goal Two of this document are intended to provide a practical, effective framework for land-use decisions regarding agricultural lands, with the overall goal of conserving agricultural lands for agricultural uses.

While not all agricultural land in Stanislaus County can be conserved, it is possible to protect agricultural areas through a combination of agricultural zoning and policies that clearly direct growth to cities and unincorporated communities with appropriate services to foster a sustainable community. By balancing the need to create housing and job opportunities for an expanding population with the need to protect our agricultural lands, we will help ensure the continued success of local agriculture.

Unlike urbanization, the parcelization of farmland has the potential to result in a gradual loss of farmland associated with the creation of parcels for 'residential purposes' and not 'agricultural purposes'. Parcels created in the agricultural area for 'residential purpose' are commonly referred to as 'ranchette' parcels. Ranchettes are characterized as rural homesites valued primarily for their residential development potential. What is classified as a ranchette size will vary based on soil type, terrain, irrigation water availability and other such factors. The land costs associated with ranchettes are driven by residential potential which cannot be supported by the agricultural income potential of the land. As the use of land transitions from production agriculture to ranchettes, landowner priorities in the areas shift from the protection of agricultural rights to the protection of residential rights.

In recognition of the legitimate agricultural reasons for parcelization of farmland there are options available to insure ranchettes are not inadvertently created. These options include maintaining minimum parcel size requirements suitable for production agriculture, restricting use of farmland to production agriculture, and establishing 'no build' provisions for the development of dwellings on newly created parcels which are not used for production agriculture or capable of production agriculture. These option may also be applied to lot line adjustments of farmland, which also have the potential to result in the creation of ranchette parcels.

\section{Objective Number 2.1: $\quad$ Continued Participation in the Williamson Act}

The California Land Conservation Act of 1965, commonly referred to as the Williamson Act, is a tax relief measure for owners of farmland. The Williamson Act permits a landowner, whose land is used for farming, to sign a contract with the County guaranteeing that the land will continue to remain in farming for a period of at least ten years. In return for this guarantee, the County assesses taxes based on the agricultural value of the land rather than the market value. Generally, this means taxes for a farmer are reduced, sometimes greatly. Participation in the Williamson Act, has been a fundamental part of Stanislaus County's agricultural land conservation program. 
Local jurisdictions implement the Williamson Act by adoption of agricultural preserves and rules governing the administration of the agricultural preserves. Adopted rules must be applied uniformly throughout the preserves and, as such, are commonly termed uniform rules. Stanislaus County has adopted the A-2 (General Agricultural) zoning district as its agricultural preserve. While the Williamson Act itself does not establish permitted uses within an agricultural preserve, permitted uses must be consistent with Principles of Compatibility outlined within the Williamson Act. The Williamson Act does establish presumed minimum parcel sizes for lands enrolled under contract. Minimum parcel sizes apply to both the creation of new parcels and parcels involved in a lot line adjustment.

The local governing jurisdiction has the ability to establish compatible uses, alternative minimum parcel sizes, and criteria for lot line adjustment based on the individualized needs of the community, provided the overall purpose and minimum standards of the Act are maintained.

Generally, the Williamson Act enjoys widespread support among landowners and government officials. The Williamson Act has helped to stabilize farm income and keep many operators in business by limiting the tax burden on contracted parcels. The Open Space Subvention Program, which is the companion to the Williamson Act, requires the State to partially reimburse local governments for forgone property tax revenues.

Stanislaus County has voluntarily participated in the Williamson Act program since 1970. Although the County's participation rate is one of the highest in the state, the percentage of land enrolled under contract has declined by four percent since the height of enrollment in 1981-82. The decline is primarily attributed to lands annexed by cities and contracts which have expired as result of notices of nonrenewal filed by property owners. Notices of nonrenewal are common in areas adjacent to city boundaries and unincorporated communities where development pressures are increasing. The passage of state legislation in 2003 establishing procedures and penalties for material breach of contracts have resulted in an increase of notices of nonrenewal throughout the entire A-2 zoning district.

Despite the trend of increasing notices of nonrenewal, cancellation requests in Stanislaus County have remained low. Generally, the Williamson Act continues to be an effective tool to help keep agricultural land in agricultural use. One reason for the increase in notices of nonrenewal may be attributed to the significant number of undersized parcels currently enrolled under contract. Since the County started participating in the Williamson Act, there have been periods when no minimum parcels size requirements existed for enrollment under contract. Currently, a minimum of 10-acres is required for enrollment under contract. While these undersized parcels may not benefit, they do face restrictions. The County has taken action to notify owners of undersized parcels of the process of nonrenewal, but few have taken advantage of the process. Increases in notices of nonrenewal in recent years have been the result of changes in State legislation.

\section{Policy 2.1}

The County shall continue to provide property tax relief to agricultural landowners by participating in the Williamson Act.

\section{Implementation Measure}

1. The County shall continue to participate in the Williamson Act, thereby providing property tax relief to farmers and ranchers who volunteer to keep their land in agricultural use.

Responsible Departments: Planning Department, Planning Commission, Board of Supervisors. 


\section{Policy 2.2}

The County shall support reasonable measures to strengthen the Williamson Act, making it a more effective tool for the protection of agricultural land.

\section{Implementation Measures}

1. The County shall encourage the State Legislature to increase Williamson Act subvention payments to local governments based on cost-of-living increases and/or a restructuring of the Williamson Act subventions schedule.

Responsible Departments: Chief Executives Office, Board of Supervisors.

2. The County will supplement the Williamson Act with other conservation tools in a comprehensive program for the protection of agricultural land.

Responsible Departments: Planning Department, Planning Commission, Board of Supervisors

\section{Policy 2.3}

The County shall ensure all lands enrolled in the Williamson Act are devoted to agricultural and compatible uses supportive of the long-term conservation of agricultural land.

\section{Implementation Measure}

1. The County shall initiate the filing of notices of nonrenewal on any parcel being used, or of a size, inconsistent with adopted uniform rules and applicable state regulations.

Responsible Departments: Planning Department, Assessors Office, Board of Supervisors

Objective Number 2.2: Discourage urbanization and the conversion of agricultural land in unincorporated areas of the County

In Stanislaus County, urbanization and farmland conversion are like two sides of the same coin. As urban areas expand to accommodate a growing population, surrounding farmland is converted to residential subdivisions, shopping centers and industrial parks.

Like many other farming areas, the towns in Stanislaus County began as agricultural service centers and located where the farms were, on the valley floor. As these towns have expanded beyond their original functions, they have expanded outward onto our richest, most productive soils. Today, population growth continues to push urban development onto farmland once in agricultural production. If the trend continues outward onto productive agricultural land to accommodate population growth, the resource base of our biggest industry will be seriously threatened.

Remote development, or development that takes place away from existing cities or urban centers, has traditionally been discouraged by planners and County officials in favor of the compact expansion of already existing urban centers. Existing County policy regarding remote development is stated in Policy Ten of the Land Use Element: "New areas for urban development (as opposed to expansion of existing areas) shall be limited to less productive agricultural areas." In theory remote development offers a better alternative to the unlimited expansion of established cities and towns into our most productive agricultural areas. However, the benefits of remote development are diminished by the impact to surrounding agricultural uses and the introduction of urban infrastructure in an agricultural area. 
In defining the County's most productive agricultural areas, it is important to recognize that soil types alone should not be the determining factor. With modern management techniques, almost any soil type in Stanislaus County can be extremely productive. At the same time, many of our most valuable agricultural commodities are produced on lesser quality soils. For example, milk is the County's top-grossing commodity and yet most of the dairy farms in Stanislaus County are located in areas that might be considered less productive agricultural lands, based solely on soil capability. Although soil types should be considered, the designation of "most productive agricultural areas" also should be based on existing uses and their contributions to the agricultural sector of our economy.

Conversion of agricultural land also occurs when nonagricultural uses are introduced into agricultural areas and when agricultural land is parceled or adjusted into sizes too small to sustain an agriculturally viable independent farming operation. The County's Agricultural land use designation and corresponding A-2 (General Agriculture) zoning recognize ranchette areas with minimum lot size requirements of $3,5,10$, and 20 acres. Ranchette areas have been identified based on significant existing parcelization of property, poor soil, location, and other factors which limit the agricultural productivity of the area. The inclusion of ranchette minimum parcel sizes in the A-2 zoning district creates the potential for future expansion of ranchette areas without the need to amend the lands Agricultural land use designation.

\section{Policy 2.4}

To reduce development pressures on agricultural lands, higher density development and in-filling shall be encouraged.

\section{Implementation Measure}

1. The County shall encourage higher density development and in-filling of already-existing urban areas.

Responsible Departments: Planning Department, Board of Supervisors

\section{Policy 2.5}

To the greatest extent possible, development shall be directed away from the County's most productive agricultural areas.

\section{Implementation Measure}

1. Until the term "Most Productive Agricultural Areas" is defined on a countywide basis, the term will be determined on a case-by-case basis when a proposal is made for the conversion of agricultural land. Factors to be considered include but are not limited to soil types and potential for agricultural production; the availability of irrigation water; ownership and parcelization patterns; uniqueness and flexibility of use; the existence of Williamson Act contracts; existing uses and their contributions to the agricultural sector of the local economy. As an example, some grazing lands, dairy regions and poultry-producing areas as well as farmlands can be considered "Most Productive Agricultural Areas." Failure to farm specific parcels will not eliminate them from being considered "Most Productive Agricultural Areas." Areas considered to be "Most Productive Agricultural Areas" will not include any land within LAFCO-approved Spheres of Influence of cities or community services districts and sanitary districts serving unincorporated communities.

Responsible Departments: Planning Department, Agricultural Commissioner, Planning Commission, Board of Supervisors 
2. Uses on agricultural land located outside a LAFCO-adopted Sphere of Influence shall be primarily devoted to agricultural and compatible uses supportive of the long-term conservation of agricultural land. Agriculturally - related uses needed to support production agriculture and uses which by their unique nature are not compatible with urban uses, may be allowed on agricultural land provided they do not conflict with the agricultural use of the area.

\section{Responsible Departments: Planning Department, Planning Commission, Board of Supervisors}

\section{Policy 2.6}

Agricultural lands restricted to agricultural use shall not be assessed to pay for infrastructure needed to accommodate urban development.

\section{Implementation Measure}

1. The County shall continue to exempt agricultural buildings designed and constructed to house farm implements, hay, grain, poultry, livestock or other horticultural products from payment of Public Facility Fees. Exempt structures shall not be a place of human habitation or a place of employment where agricultural products are processed, treated or packaged, nor shall it be a place used by the public.

Responsible Departments: Board of Supervisors

\section{Policy 2.7}

Proposed amendments to the General Plan Diagram (map) that would allow the conversion of agricultural land to non-agricultural uses shall be approved only if they are consistent with the County's conversion criteria.

\section{Implementation Measure}

1. Procedures for processing General Plan amendments shall incorporate the following requirements for evaluating proposed amendments to the General Plan Diagram (map) that would allow the conversion of agricultural land to urban uses:

Conversion Consequences. The direct and indirect effects, as well as the cumulative effects, of the proposed conversion of agricultural land shall be fully evaluated.

Conversion Considerations. In evaluating the consequences of a proposed amendment, the following factors shall be considered: plan designation; soil type; adjacent uses; proposed method of sewage treatment; availability of water, transportation, public utilities, fire and police protection, and other public services; proximity to existing airports and airstrips; impacts on air and water quality, wildlife habitat, endangered species and sensitive lands; and any other factors that may aid the evaluation process.

Conversion Criteria. Proposed amendments to the General Plan Diagram (map) that would allow the conversion of agricultural land to urban uses shall be approved only if the Board of Supervisors makes the following findings:

A. Overall, the proposal is consistent with the goals and policies of the General Plan.

B. There is evidence on the record to show a demonstrated need for the proposed project based on population projections, past growth rates and other pertinent data. 
C. No feasible alternative site exists in areas already designated for the proposed uses.

D. Approval of the proposal will not constitute a part of, or encourage, piecemeal conversion of a larger agricultural area to non-agricultural uses, and will not be growth-inducing (as used in the California Environmental Quality Act).

E. The proposed project is designed to minimize conflict and will not interfere with agricultural operations on surrounding agricultural lands or adversely affect agricultural water supplies.

F. Adequate and necessary public services and facilities are available or will be made available as a result of the development.

G. The design of the proposed project has incorporated all reasonable measures, as determined during the CEQA review process, to mitigate impacts to agricultural lands, fish and wildlife resources, air quality, water quality and quantity, or other natural resources.

Responsible Departments: Planning Department, Planning Commission, Board of Supervisors

\section{Policy 2.8}

In order to further the conservation of agricultural land, the subdivision of agricultural lands shall not result in the creation of parcels for 'residential purposes'. Any residential development on agriculturally zoned land shall be incidental and accessory to the agricultural use of the land.

\section{Implementation Measure}

1. The subdivision of agricultural land consisting of unirrigated farmland, unirrigated grazing land, or land enrolled under a Williamson Act contract, into parcels of less than 160-acres in size shall be allowed provided a "no build" restriction on the construction of any residential development on newly created parcel(s) is observed until one or both of the following criteria is met:

- $\quad 90 \%$ or more of the parcel shall be in production agriculture use with its own on-site irrigation infrastructure and water rights to independently irrigate. For land which is not irrigated by surface water, on-site irrigation infrastructure may include a selfcontained drip or sprinkler irrigation system. Shared off-site infrastructure for drip or sprinkler irrigation systems, such as well pumps and filters, may be allowed provided recorded long-term maintenance agreements and irrevocable access easements to the infrastructure are in place .

- Use of the parcel includes a confined animal facility (such as a commercial dairy, cattle feedlot, or poultry operation) or a commercial aquaculture operation.

Responsible Departments: Planning Department, Planning Commission, Board of Supervisors.

\section{Policy 2.9}

Lot-line adjustments involving agricultural land shall be primarily created and properly designed for agricultural purposes without materially decreasing the agricultural use of the project site. 


\section{Implementation Measure}

1. In terms of minimum parcel size and residential building intensity, a greater number of nonconforming parcels shall not be created by lot-line adjustment. The following criteria shall apply when nonconforming parcels are involved in a lot-line adjustment:

- $\quad$ Nonconforming parcels greater than 10-acres in size shall not be adjusted to a size smaller than 10-acres, unless the adjustment is needed to address a building site area or correct for a physical improvement which is found to encroach upon a property line. In no case shall a parcel enrolled in the Williamson Act be reduced to a size smaller than 10 -acres.

- $\quad$ Nonconforming parcels less than10-acres in size may be adjusted to a larger size, 10 acres or greater in size if enrolled in the Williamson Act, or reduced, if not enrolled in the Williamson Act, as needed to address a building site area or correct for a physical improvement which is found to encroach upon a property line.

Responsible Departments: Planning Department, Planning Commission, Board of Supervisors.

\section{Policy 2.10}

Minimum parcel sizes allowed for lands designated Agriculture shall not promote the expansion of existing, or creation of new, ranchette areas.

\section{Implementation Measures}

1. Minimum parcel sizes of 40 - or 160 - acres shall be appropriate for lands designated Agriculture.

Responsible Departments: Planning Department, Planning Commission, Board of Supervisors

2. In recognition of 3-, 5-, 10, and 20- acre minimum parcel sizes being appropriate for ranchette areas, no additional land designated as Agriculture shall be rezoned to A-2-3, 5, 10 , or 20.

Responsible Departments: Planning Department, Planning Commission, Board of Supervisors

3. The County shall evaluate and modify as needed, the remote development policy of the Land Use element as part of a comprehensive General Plan update to insure such development does not impact surrounding agricultural uses or introduce urban infrastructure into an agricultural area.

Responsible Departments: Planning Department, Planning Commission, Board of Supervisors

\section{Objective Number 2.3: Expansion of Cities and Unincorporated Communities}

The Stanislaus Local Agency Formation Commission (LAFCO) is the local agency responsible for coordinating logical and timely changes in local governmental boundaries, including Spheres of Influence (SOI). The spheres of influence delineate the probable ultimate boundaries and service areas of the cities, and are intended to promote the efficient provision of urban services, including sewer, water, police protection and fire protection. Similarly, community services districts and sanitary districts serving unincorporated communities also have adopted spheres of influence that indicate their probable ultimate boundaries. LAFCO's efforts are directed to seeing that services are provided efficiently and economically while agricultural and open-space lands are protected. 
With the approval of LAFCO, spheres of influence can be expanded to accommodate growth. The question of whether or not proposed expansions should be allowed is decided solely by LAFCO. LAFCO is an independent agency created by state law. In Stanislaus County the LAFCO is composed of two county supervisors; two city council representatives; and one public member. As an independent agency, LAFCO is not required to adhere to county policies, but state law requires LAFCO to consider conformity with all applicable general plans in the review of all proposals. As such, this agricultural element, and the county general plan as a whole, can have an effect on the actions of LAFCO.

In recognition that unincorporated land within the established spheres of influence will be urbanized, these lands generally are designated Agriculture and zoned General Agriculture (A-2) until annexed by the city or special district.

Existing policy in the Land Use Element delineates the County's role in managing the development of agriculturally zoned lands within city spheres of influence. Reflecting agreements between the County and all nine cities, these policies provide that the County shall refer all development proposals to the appropriate city to determine whether or not the proposal should be approved. Development, other than agricultural uses and churches, cannot be approved by the County unless written communication is received from the city memorializing their approval.

The Land Use Element also includes policies regarding the development of unincorporated communities and the expansion of urban boundaries (Policies Six and Thirteen). The County is actively encouraging the upgrading of unincorporated communities through the redevelopment and community development block grant programs, which provide significant tools for improving infrastructure and enhancing the quality of life in these areas.

\section{Policy 2.11}

The County recognizes the desire of cities and unincorporated communities to grow and prosper and shall not oppose reasonable requests consistent with city and county agreements to expand, provided the resulting growth minimizes impacts to adjacent agricultural land.

\section{Implementation Measures}

1. The County shall continue to urge LAFCO to strengthen its policies, standards and procedures for evaluating proposed annexations of agricultural land and proposed expansions of service districts or spheres of influence onto agricultural land to insure resulting urban growth minimizes impacts to adjacent agricultural lands.

Responsible Departments: Planning Department, Planning Commission, Board of Supervisors, Agricultural Commissioner

2. The County shall actively review LAFCO referrals to insure proposed projects are consistent with County General Plan polices.

Responsible Departments: Planning Department, Agricultural Commissioner, Board of Supervisors

\section{Policy 2.12}

In order to minimize impacts to adjacent agricultural land, the County shall encourage LAFCO to use physical features such as roads and irrigation laterals as the boundaries for sphere of influence expansions. 


\section{Implementation Measure}

1. The County shall encourage LAFCO to consider buffer guidelines adopted by the County when cities or community services districts and sanitary districts serving unincorporated communities propose to expand their boundaries.

Responsible Departments: Planning Department, Planning Commission, Board of Supervisors, Agricultural Commissioner

\section{Policy 2.13}

In recognition that unincorporated land within spheres of influence of cities or community services districts and sanitary districts serving unincorporated communities ultimately will be urbanized, the County shall cooperate with cities and unincorporated communities in managing development in sphere of influence areas.

\section{Implementation Measures}

1. The County will continue to implement its policies and agreements with cities regarding the development of unincorporated lands within spheres of influence.

Responsible Departments: Planning Department, Planning Commission, Board of Supervisors

2. The County will continue to implement policies in the Land Use Element regarding the development of unincorporated communities and expansion of their urban, or service district, boundaries.

Responsible Departments: Planning Department, Planning Commission, Board of Supervisors

\section{Objective Number 2.4: $\quad$ Assessing and mitigating Impacts of farmland conversion}

The conversion of agricultural land to non-agricultural uses has far-reaching impacts on the land, water and air resources that support our biggest industry. For example, taking out an almond orchard to accommodate urban development may involve paving over groundwater recharge areas, which will have a long-term effect on groundwater resources. Similarly, new roads providing access to the development may increase traffic congestion, resulting in a cumulative impact on air quality.

The California Environmental Quality Act (CEQA) requires the County to consider the environmental consequences of development-related projects and to ensure that adverse environmental impacts are avoided or minimized as much as possible. If the County determines in its Initial Study that a project could have a significant adverse environmental effect, the County must require preparation of an Environmental Impact Report (EIR) to fully assess potential impacts, propose ways to minimize or mitigate those impacts, and consider alternatives to the proposed project. The County may approve a project only if mitigation measures are adopted whenever feasible to avoid or reduce all significant environmental impacts or findings of 'overriding considerations' are adopted.

Under CEQA Guidelines, the County has some discretion in determining whether the conversion of agricultural land will have a significant adverse effect on the environment. A project will normally have a significant effect on the environment if it will convert prime agricultural land to nonagricultural use or impair the productivity of prime agricultural land. "Prime agricultural land" is not defined under CEQA. Several attempts have been made in years past to allow or require local governments to establish a threshold of agricultural land loss for the purpose of determining a 
significant effect on the environment and thereby necessitating an EIR. However, instead of using an arbitrary threshold such as 100 acres to trigger an EIR, the County prefers to evaluate each project on a case-by-case basis. When the County determines that under the specific circumstances of the proposed project the conversion of agricultural land could have a significant effect, the County requires preparation of an EIR.

The analysis of the impacts of farmland conversion are often limited to a discussion of the prime soils that the project would make unavailable for farming, but rarely identifies the impacts on surrounding farming operations. Neither CEQA nor the State CEQA Guidelines contain detailed procedures or guidance concerning when and how agencies should address farmland conversion impacts. The County may amend its own CEQA Guidelines to include local guidelines for assessing the impacts of farmland conversion.

A common strategy for mitigating the loss of farmland is to require the permanent protection of farmland based on an identified ratio to the amount of farmland converted. A viable option for permanent protection is purchase of an agricultural conservation easement on farmland. Agricultural conservation easements generally restrict the non-agricultural use of property in perpetuity and are overseen by a trust established with a goal of promoting farmland conservation. The purchase of agricultural conservation easements is typically accomplished in one of two methods: 1) the developer works directly with a trust to purchase the required conservation easement prior to development or 2) the developer pays a fee to be used by a trust to purchase an agricultural conservation easement at a later date. While payment of a fee is typically easier for the developer, it is not always a guaranteed method to attaining the desired results. Fees paid at current cost may not keep pace with the escalating land costs and trusts must recover the cost of administering fees until a conservation easement is purchased. At the same time, a landowner wanting to sell an agricultural conservation easement may not be available at the time a development project is approved. A mitigation program focused on agricultural conservation easements must maintain a balance between the practical acquisition and actual cost of agricultural conservation easements.

To be effective, lands placed under easement must be strategically located to insure the viability of the surrounding farmland is protected. An isolated island of agricultural land surrounded by development or agriculturally non-viable parcels has little positive impact on efforts to protect farmland.

\section{Policy 2.14}

When the County determines that the proposed conversion of agricultural land to non-agricultural uses could have a significant effect on the environment, the County shall fully evaluate on a projectspecific basis the direct and indirect effects, as well as the cumulative effects of the conversion.

\section{Implementation Measures}

1. The County will continue to evaluate each project on a case-by-case basis to determine whether the conversion of agricultural land will have a significant adverse effect on the environment.

Responsible Departments: Agricultural Commissioner, UC Cooperative Extension, Planning Department, Planning Commission, Board of Supervisors. 
2. When it determines that the conversion of agricultural land will have a significant adverse effect on the environment, the County will continue to require preparation of an EIR to fully assess the impacts of the conversion, propose mitigation measures, and consider alternatives to the proposed project.

Responsible Departments: Planning Department, Planning Commission, Board of Supervisors.

\section{Policy 2.15}

In order to mitigate the conversion of agricultural land resulting from a discretionary project requiring a General Plan or Community Plan amendment from 'Agriculture' to a residential land use designation, the County shall require the replacement of agricultural land at a 1:1 ratio with agricultural land of equal quality located in Stanislaus County.

\section{Implementation Measure}

1. Mitigation shall be applied consistent with the Farmland Mitigation Program Guidelines presented in Appendix "B".

Responsible Departments: Agricultural Commissioner, UC Cooperative Extension, Planning Department, Planning Commission, Board of Supervisors.

\section{Policy 2.16}

The County shall participate in local efforts to identify strategic locations for the purchase of agricultural conservation easements by land trusts and shall promote the long-term viability of farmland in areas surrounding existing farmland held under conservation easements.

\section{Implementation Measure}

1. To facilitate the mitigation of the impacts of farmland conversion, the County may make information available on private, non-profit agricultural land trusts, may serve on committees that are formed for the purpose of establishing an agricultural land trust, and may coordinate County mitigation programs with the land trust once it is established.

Responsible Departments: Agricultural Commissioner, UC Cooperative Extension, Planning Department, Planning Commission, Board of Supervisors.

\section{Policy 2.17}

The County shall work cooperatively with the nine cities within the County and to encourage them to adopt agricultural conservation policies or ordinances which are consistent with County policies or ordinances in order to undertake an integrated, comprehensive Countywide approach to farmland conservation. It is the ultimate goal of the County to have all nine cities participate in or adopt an agricultural mitigation ordinance that is the same as or substantially similar.

\section{Implementation Measure}

1. The County shall facilitate efforts to have all nine cities participate in or adopt an agricultural mitigation ordinance that is the same as or substantially similar to adopted County ordinances addressing agricultural mitigation. 


\section{Objective Number 2.5: $\quad$ Limit the Impact of Antiquated Subdivisions}

One of the biggest threats to Stanislaus County's agricultural economy is the potential creation of hundreds of ranchettes in antiquated subdivisions.

Antiquated subdivisions are subdivisions created in the early part of the 1900's and exist on paper but have never been developed or sold in lots. Numerous antiquated subdivisions are located throughout Stanislaus County, involving more than 3,000 lots ranging in size from 3,250 square feet to 20 acres or more. If these lots were sold and developed, the loss of agricultural land coupled with the impact on surrounding agricultural operations could be devastating to the long-term viability of the agricultural economy.

Created prior to enactment of the State Subdivision Map Act and the California Environmental Quality Act, antiquated subdivisions were created without any kind of formal review to evaluate their economic and environmental consequences to the County. In addition to having adverse impacts on agriculture, antiquated subdivisions pose a variety of environmental threats including groundwater contamination from the concentration of on-site septic systems and the generation of dust and auto emissions from increased traffic on unimproved access roads. The County's ability to provide emergency services such as fire protection, sheriff and ambulance services also could be adversely affected. Similarly, potential impacts of antiquated subdivisions on schools, parks and recreation have never been fully evaluated.

In 2000 the Stanislaus County Board of Supervisors amended the County Zoning Ordinance to address antiquated subdivisions. The amendment addresses antiquated subdivisions in the General Agriculture (A-2) zoning district by limiting the ability to place a dwelling on parcels of less than 20-acres in size without approval of a discretionary permit. The ordinance is based on the need to find the dwelling will be consistent with the County's General Plan, will not likely create a concentration of residential uses in the vicinity or induce other similarly situated parcels to become developed with single-family dwellings, and will not be substantially detrimental to or in conflict with agricultural uses of other property in the vicinity.

\section{Policy 2.18}

Construction of a dwelling on an antiquated subdivision parcel shall only be allowed when such development does not create a concentration of residential uses or conflict with agricultural uses of other property in the vicinity.

\section{Implementation Measure}

1. The County shall continue to implement existing zoning ordinance provisions addressing antiquated subdivisions.

Responsible Departments: Planning Department, Planning Commission and Board of Supervisors 


\section{GOAL THREE}

Protect the natural resources that sustain our agricultural industry.

Agriculture depends directly on the land, air, water and soil resources to sustain its productivity. The success of agriculture in Stanislaus County can be largely attributed to the availability of these resources for the production of a wide variety of products.

The continued availability of soil, high quality water and clean air cannot be taken for granted. In the process of urbanization to accommodate a booming population, Stanislaus County is losing farmlands to urban development by cities. At the same time, there is increasing competition between agriculture and urban uses for limited water resources. Ultimately these problems threaten the County's agricultural economy and our ability to help feed the nation.

Urbanization and the conversion of agricultural land are addressed under Goal Two, which focuses primarily on land-use issues regarding our agricultural lands. Other resource problems such as air quality, water quality and supply, and soil quality are addressed in the following section of this document. The policies presented under Goal Three are intended to ensure the long-term protection of the natural resources that sustain our agricultural industry.

\section{Objective Number 3.1: $\quad$ Air Quality}

Air quality in the San Joaquin Valley is monitored and standards are enforced by the California Air Resources Board and the San Joaquin Valley Air Pollution Control District, which is composed of the eight counties in the San Joaquin Valley air basin. The District was formed in recognition of the fact that air pollution is not limited by County lines--it is a regional problem affecting the entire valley. The lack of consistent standards and enforcement from one County to another makes it difficult to effectively address the cumulative impacts of pollution.

The Conservation/Open Space and Circulation Elements of the General Plan include policies and implementation measures to improve air quality by promoting communication, cooperation and coordination among agencies involved in air quality programs; working to accurately determine and mitigating air quality impacts of proposed projects; to ensure that circulation systems shall be designed and maintained to minimize traffic congestion and air pollution; and to support efforts to increase public awareness of air quality problems and solutions.

\section{Policy 3.1}

The County shall continue to coordinate with the San Joaquin Valley Air Pollution Control District.

\section{Implementation Measure}

1. The County shall continue to refer development proposals to the San Joaquin Valley Air Pollution Control District for their review and analysis of impacts on air quality.

\section{Policy 3.2}

The County shall assist the San Joaquin Valley Air Pollution Control District in implementation of adopted plans and regulations. 


\section{Implementation Measure}

1. The County shall require development proposals to incorporate all applicable air quality regulations and, where required, to include reasonable mitigation measures.

Responsible Departments: Planning Department, Planning Commission, Board of Supervisors

\section{Policy 3.3}

The County shall encourage the development and use of improved agricultural practices that improve air quality and are economically feasible.

\section{Implementation Measure}

1. The County shall encourage and support the development and use of improved agricultural practices aimed at reducing the production of fine particles and other sources of air pollution.

Responsible Departments: Agricultural Commissioner, U.C. Cooperative Extension, Board of Supervisors

\section{Objective Number 3.2: $\quad$ Water Resources}

Water is the lifeblood of agriculture in Stanislaus County. To supplement an average rainfall of just 12 inches per year, local agriculture relies on a network of irrigation water delivery systems to sustain its broad diversity of valuable crops.

Compared to many other areas of the arid Central Valley, Stanislaus County has abundant water resources, at least in times of normal rainfall. The availability of high-quality, low-cost irrigation water traditionally has given local agriculture a competitive edge and has been largely responsible for its success. The main sources of irrigation water are the Stanislaus, Tuolumne and San Joaquin River watersheds, all of which originate in the Sierra Nevada Mountains. Groundwater is used to supplement irrigation supplies, and is the major source of domestic and industrial water.

The quality of groundwater is determined by the geological formations through which it filters and thereby cannot be controlled. Groundwater recharge occurs by water conducting through the gravels of major streams and rivers, seepage from reservoirs, irrigations and rainfall of well drained alluvial soils in the valley portions of the County. Decreasing groundwater quality in areas of the county is having adverse effects on domestic water suppliers, as well as the agricultural lands. As groundwater becomes unavailable for domestic use, other sources have to be found. As a result, urban and agricultural users are becoming more competitive for water supplies.

Conservation is the most cost-effective way to ensure adequate water supplies for all residents of Stanislaus County. Local farmers long have practiced conservation methods, and their ability to survive dry years is indicative of their success. Research is continually improving agricultural technology, and water-saving innovations are continually being adapted by local growers.

Domestic and industrial users also need to be informed about the need for conservation and methods of lowering their water requirements. All types of water sources in the County are increasingly interdependent. The availability of irrigation water is affected by the use of water by city-dwellers and businesses; the availability of drinking water and industrial water is affected by agricultural practices. 


\section{Policy 3.4}

The County shall encourage the conservation of water for both agricultural and urban uses.

\section{Implementation Measures}

1. The County shall encourage water conservation by farmers by providing information on irrigation methods and best management practices and coordinating with conservation efforts of the Farm Bureau, Resource Conservation Districts, Natural Resource Conservation Service, and irrigation districts.

Responsible Departments: Agricultural Commissioner, U.C. Cooperative Extension, Board of Supervisors

2. The County shall encourage urban water conservation and coordinate with conservation efforts of cities, local water districts and irrigation districts that deliver domestic water.

Responsible Departments: Department of Environmental Resources, Board of Supervisors

3. The County shall continue to implement adopted landscape and irrigation standards designed to reduce water consumption in the landscape environment.

Responsible Departments: Planning Department, Planning Commission, Board of Supervisors

4. The County shall work with local irrigation districts to preserve water rights and ensure that water saved through conservation may be stored and used locally, rather than "appropriated" and moved to metropolitan areas outside of Stanislaus County.

Responsible Departments: Board of Supervisors

\section{Policy 3.5}

The County will continue to protect the quality of water necessary for crop production and marketing.

\section{Implementation Measures}

1. The County shall continue to require analysis of groundwater impacts in Environmental Impact Reports for proposed developments.

Responsible Departments: Department of Environmental Resources, Planning Department, Planning Commission, Board of Supervisors

2. The County shall investigate and adopt appropriate regulations to protect water quality. Responsible Departments: Department of Environmental Resources, Planning Department, Planning Commission, Board of Supervisors

\section{Objective Number 3.3: $\quad$ Soil Resources}

The continued success of agriculture in Stanislaus County depends on conserving our soil resource. In addition to supporting the production of crops and livestock forage, soil is a vital part of the ecosystem and a record of past biological and physical processes. Formed slowly through the interaction of climate, living and decomposing organisms, local geology and erosion, soil is considered a non-renewable resource that requires proper management to ensure its continued productivity. 
There are two main soil management problems in Stanislaus County: salinity, or the build-up of salts, and erosion caused by wind, water and irrigation. Salinity and irrigation induced salinity is especially problematic west of the San Joaquin River. Low quality irrigation water and poor drainage have resulted in the build up of salt and mineral concentrations in the soil. Wind erosion is more widespread in the coarse textured soils east of the San Joaquin River, resulting in the loss of productive topsoil and contributing to air and water quality problems.

Resource Conservation Districts (RCDs) provide assistance to control soil erosion and runoff, water conservation, stabilize soils, and protect water quality through cooperative agreements and grants with the USDA Natural Resources Conservation Service (NRCS). Through these agreements, the RCDs can prioritize resource concerns so that funding for conservation practices can be directed through NRCS.

The county is served by two Resource Conservation Districts. The East Stanislaus Resource Conservation District sphere of influence is east of the San Joaquin River and extends to the county lines. The West Stanislaus Resource Conservation District is located west of the San Joaquin River and extends to the county lines.

\section{Policy 3.6}

The County shall encourage the conservation of soil resources.

\section{Implementation Measures}

1. The County shall continue to provide soil management information and coordinate with soil conservation efforts of local, state, and federal agencies.

Responsible Departments: Agricultural Commissioner, U.C. Cooperative Extension

2. The County shall support efforts of local Resource Conservation Districts in their activities to support local agriculture.

Responsible Departments: Board of Supervisors

3. The County shall continue to refer proposed developments whenever appropriate to Resource Conservation Districts and irrigation districts for their review and analysis of impacts on soil resources.

Responsible Departments: Planning Department 


\section{DEFINITIONS}

Agricultural Land - Any land suited for agriculture.

Agricultural Uses - Land uses that are directly connected with or customarily incidental to agriculture.

Agriculture - The tilling of the soil, the raising of crops, horticulture, viticulture, small livestock farming, dairying, aquaculture, or animal husbandry, including all uses customarily incidental thereto but not including slaughterhouses, fertilizer yards, bone yards or plants for the reduction of animal matter or any other industrial use which is similarly objectionable because of noise, odor, smoke, dust or fumes.

Agricultural Service Establishment - A business engaging in activities designed to aid production agriculture. Service does not include the provision of tangible goods except those sold directly to farmers and used specifically to aid in production of farm animals or crops. Nor does service include any business which has the primary function of manufacturing products.

Buffer - A physical separation such as a topographic feature, a substantial stand of trees, a water course or similar feature that serves to protect or insulate one type of land use from another.

Clustering - A development technique that involves the grouping together of residences and other structures in a relatively small area, as opposed to dispersing those structures over a larger area.

Farmland - The type of agricultural land best suited for growing crops. In this document, "farmland" is used synonymously with "agricultural land" to mean any land suited for agriculture.

Grazing Land - Land on which existing vegetation is suited for the grazing of livestock.

Non-Agricultural Uses - Land uses that are not directly connected with or customarily incidental to agriculture.

Production Agriculture - Agriculture for the purpose of producing any and all plant and animal commodities for commercial purposes.

Ranchette - An individual parcel of land in an agricultural zone valued for its residential potential which cannot be supported by the agricultural income potential of the land.

Remote Development - Development that takes place away from existing cities or urban centers.

Right-to-Farm Ordinance - Stanislaus County Ordinance Code, Section 9.32.010, Chapter 9. A local ordinance that protects the rights of farmers to carry on their "normal" agricultural practices with a decreased risk of nuisance lawsuits.

Rural - Characteristic of the country, as distinguished from city or town.

Setback - The distance between the nearest point of the building or structure and the right-of-way or easement borderline or property line. 
Urban - Characteristic of the city, as distinguished from the country.

Urban Development - In incorporated areas, development that is served by both public water and public sewer services; in unincorporated areas, development that is served by public water and/or public sewer services.

Urbanization - The process of changing from rural to urban in character.

I:IPLANNINGIGENERAL PLANIAgriculture ElementIAG Element Final.wpd 


\section{APPENDIX "A" STANISLAUS COUNTY BUFFER AND SETBACK GUIDELINES}




\section{Stanislaus County Buffer and Setback Guidelines}

\section{Purpose and Intent:}

The purpose of these guidelines is to protect the long-term health of local agriculture by minimizing conflicts resulting from normal agricultural practices as a consequence of new or expanding nonagricultural uses approved in or adjacent to the A-2 (General Agriculture) zoning district.

The intent of these guidelines is to establish standards for the development and maintenance of buffers and setbacks designed to physically and biologically avoid conflicts between agricultural and non-agricultural uses.

\section{Applicability:}

These guidelines shall apply to all new or expanding non-agricultural uses approved by discretionary permit ${ }^{1}$ in the A-2 zoning district or on a parcel adjoining the A-2 zoning district. Nonagricultural uses located within a Local Agency Formation Commission (LAFCO) adopted Sphere of Influence (SOI) for an incorporated city shall be subject to these guidelines if the project site is located within 300 feet of any production agriculture operation, as defined by the Stanislaus County General Plan Agricultural Element, or the outer boundary of the SOI at the time of approval.

Buffer and setback requirements established by these guidelines shall be located on the parcel for which a discretionary permit is sought and shall protect the maximum amount of adjoining farmable land.

\section{Buffer Design Standards for New Non-Agricultural Uses:}

- $\quad$ All projects shall incorporate a minimum 150-foot wide buffer. Projects which propose people intensive outdoor activities, such as athletic fields, shall incorporate a minimum 300foot wide buffer. All buffers shall incorporate a solid wall and vegetative screen consistent with the following standards:

Fencing: $\quad$ A 6-foot high solid wall of uniform construction shall be installed along any portion of a buffer where the project site and the adjoining agricultural operation share a common parcel line.

Vegetative Screen: (minimum standards)

- Two staggered rows of trees and shrubs characterized by evergreen foliage extending from the base of the plant to the crown. Fast growing plants with a shortlife span shall be discouraged.

- $\quad$ Trees and shrubs should be vigorous, drought tolerant and at least 6-feet in height at the time of installation.

- Plants shall have $50 \%$ to $70 \%$ porosity (i.e., approximately $50 \%$ to $75 \%$ of the plant is air space).

- $\quad$ Plant height shall vary in order to capture drift within 4-feet of ground application.

- A mature height of 15 -feet or more shall be required for each tree.

${ }^{1}$ For purposes of these guidelines discretionary permit shall mean any general plan amendment, community plan amendment, rezone, tentative map, parcel map, use permit (excluding single-family dwellings in the A-2 zoning district), or variance processed by the County Planning \& Community Development Department. 
- $\quad$ To ensure adequate coverage, two staggered rows shall be located 5-feet apart and consist of minimum 5 gallon plants at least 6 -feet tall planted 10 -feet on center. Alternative spacing between rows may be authorized to accommodate the needs of specific plant species.

- $\quad$ Permitted uses within a buffer area shall include: public roadways, utilities, drainage facilities, landscaping, parking lots and similar low human intensity uses. Walking and bike trails shall be allowed within buffers provided they are designed without rest areas.

- $\quad$ Landscaping shall be designed to exclude turf areas which could induce activities and add to overall maintenance costs and water usage.

\section{Buffer and Setback Design Standards for Expanding Non-Agricultural Uses:}

- Where existing development on a project site will allow, accommodation of a buffer as required for new non-agricultural uses shall be provided.

- Where existing development on a project site will not allow a buffer as required for new nonagricultural uses, fencing and vegetative screening as required for new non-agricultural uses shall be provided within the area available.

- A minimum building setback of 150-feet, measured from the property line of any adjoining property located in the A-2 zoning district, shall be required for any addition to an existing building or any new building associated with the expansion of a non-agricultural use.

\section{Buffer and Setback Maintenance:}

- $\quad$ Projects subject to these guidelines shall be conditioned to require the property owner(s) be responsible for all aspects of on-going maintenance of buffers and setback areas. The property owner(s) shall be responsible for maintaining landscape plants in a healthy and attractive condition.

- $\quad$ A landowners association or other appropriate entity shall be required to maintain buffers to control litter, fire hazards, pests, and other maintenance problems when a project consists of multiple parcels which may be held under separate ownership.

- $\quad$ The property owner, landowners association, or responsible entity shall be responsible for maintaining landscape plants in a healthy and attractive condition. Dead or dying plants shall be replaced with materials of equal size and similar variety within 30-days of weather permitting.

- When buffers are required as part of a specific plan, the County may require dedication of buffer areas and formation of service district to insure long-term up keep and maintenance of the buffer.

\section{Agricultural Transition:}

- $\quad$ The Board of Supervisors may authorize the abandonment and reuse of buffer areas if agricultural uses on all adjacent parcels within 150-foot radius of the project site have permanently ceased. 


\section{Alternative Buffer and Setback Design Standards:}

- $\quad$ Any alternative buffer and setback design standards proposed by a project applicant shall be reviewed and supported by the Stanislaus County Agricultural Advisory Board prior to consideration by the Stanislaus County Planning Department. In no case, shall the required standards be reduced, unless the proposed alternative is found to provide equal or greater protection to surrounding agricultural uses.

I:IPLANNINGIGENERAL PLANIAgriculture Element|Appendix A - Ag Element Buffer Guidelines.wpd 


\begin{abstract}
Appendix G
Ventura County, CA

Resources Element of the General Plan - Farmland Resources Goals, Policies and Programs
\end{abstract}

Ventura County Department of Agriculture - Agricultural/Urban Buffer Policy 


\subsection{Farmland Resources}

Agriculture plays an important role in the National, State, and County economy. Ventura County is one of the principal agricultural counties in the State, ranking tenth in 1987, with a total income of over 610 million dollars and ranked seventeenth in farm earnings out of 3,175 counties nationally.

This high productivity is made possible by the County's abundance of the natural resources required for agricultural production; primarily soils, water, climate and topography.

The first step in evaluating and preserving farmland is to inventory existing resources. For inventorying County farmlands, the Federal Important Farmlands Inventory (IFI) system is used. This system generally evaluates farmland in light of its productive capabilities rather than the mere presence of ideal soil conditions. The system effectively recognizes a great deal of land in California and Ventura County which would not ordinarily be classified as "prime" under the old evaluation system, but which is, nevertheless, among the most productive land in the country.

The Important Farmland Inventory uses five classifications: Prime Farmland, Farmland of Statewide Importance, Unique Farmland, Farmland of Local Importance, and Grazing Land. The minimum mapping unit is 10 acres, except for Grazing Land which is 40 acres. Areas smaller than the minimum mapping unit are not considered as agricultural land.

Prime Farmland and Farmland of Statewide Importance were identified by the Department of Conservation in cooperation with the United States Department of Agriculture Soil Conservation Service. Both Unique Farmland and Farmland of Local Importance are identified by local advisory committees composed of members of the agricultural community, citizens groups, and concerned public agencies. (For a map of Important Farmlands Inventory, refer to Resources Appendix.)

Erosion of soil is a problem in much of the County. This erosion problem is closely correlated with steep slopes or areas subject to flooding. Agricultural development on hillsides has caused erosion and the subsequent siltation.

The County has adopted a number of programs designed to preserve farmland. These programs include:

- The Agricultural land use designation (see Land Use Chapter), which established a forty acre minimum parcel size and A-E zoning;

- Participation in Greenbelt Agreements and the Guidelines for Orderly Development with the cities which seek to prevent urban encroachment into agricultural areas (see Land Use Chapter).

- Widespread use of Land Conservation Act Contracts to provide tax rate reductions as an incentive for maintaining agriculture.

- Participation in numerous water resource development and conservation programs to ensure longterm availability of water for agriculture.

The goals, policies, and programs which apply to farmland are as follows:

\subsubsection{Goals}

1. Preserve and protect irrigated agricultural lands as a nonrenewable resource to assure the continued availability of such lands for the production of food, fiber and ornamentals.

2. Encourage the continuation and development of facilities and programs that enhance the marketing of County grown agricultural products.

\subsubsection{Policies}

1. Discretionary development located on land designated as Agricultural (see Land Use Chapter) and identified as Prime Farmland or Farmland of Statewide Importance on the State's Important Farmland Inventory, shall be planned and designed to remove as little land as possible from potential agricultural production and to minimize impacts on topsoil.

2. Hillside agricultural grading shall be regulated by the Public Works Agency through the Hillside Erosion Control Ordinance. 
3. Land Conservation Act (LCA) Contracts shall be encouraged on irrigated farmlands.

4. The Public Works Agency shall plan transportation capital improvements so as to mitigate impacts to important farmlands to the extent feasible.

5. The County shall preserve agricultural land by retaining and expanding the existing Greenbelt Agreements and encouraging the formation of additional Greenbelt Agreements.

6. Discretionary development adjacent to Agricultural-designated lands shall not conflict with agricultural use of those lands.

\subsubsection{Programs}

1. The Planning Division, in conjunction with the Agricultural Commissioner, Farm Advisor, Agricultural Advisory Committee and Assessor's Office, will administer, periodically review, and update as necessary the County's Land Conservation Act Guidelines and standard contract language.

2. The Planning Division, in conjunction with the Agricultural Commissioner, Farm Advisor and Agricultural Advisory Committee, will develop and implement standards governing development adjacent to agricultural uses. The standards should address fencing and spray buffers between agricultural areas and residences, off-site flood control measures, siltation control from grading operations and the development of a standard County-imposed entitlement condition which notifies new property owners of County and State laws protecting agricultural operations. After the development of standards, they could be added as policies into the General Plan to guide future land use decisions.

3. The Planning Division will continue to work with State and Federal agencies to periodically update the Important Farmlands Inventory Map to reflect current conditions.

4. The Planning Division will prepare an annual status report on Land Conservation Act Contracts (LCA), agricultural acreage, and other agriculture related information.

\subsection{Scenic Resources}

The visual beauty and aesthetic quality of the natural landscape in Ventura County are significant resources. The County's natural visual resources are largely composed of the varied topography, exposed geological formations, heterogeneous vegetation, beaches and waterways. The man-made environment of parks, golf courses, harbors, public buildings, and major commercial, industrial, and residential developments can also contribute to, or detract from, scenic resource quality. The scenic resources of Ventura County, especially the coastline, within the viewshed of the County's lakes, and along designated State and County Scenic Highways, are of considerable value both in providing a pleasurable environment for local citizens and in stimulating tourism. Coastline resources are discussed in the Coastal Area Plan, and the viewshed of lakes and scenic highways are discussed herein.

Conservation of scenic resources is most critical where the resources will be frequently and readily viewed, as from a highway, or where the resource is particularly unique.

Ventura County has identified the viewsheds of lakes and State or County designated scenic highways as being worthy of special protection. These protected areas are described as Scenic Resource Areas which are depicted in Resource Protection Map (Figure 1). In addition, area plans may identify local scenic resources as Scenic Resource Areas unique or of significant importance to that area.

The goals, policies and programs which apply to scenic resources include:

\subsubsection{Goals}

1. Preserve and protect the significant open views and visual resources of the County.

2. Protect the visual resources within the viewshed of lakes and State and County designated scenic highways, and other scenic areas as may be identified by an area plan.

3. Enhance and maintain the visual appearance of buildings and developments. 


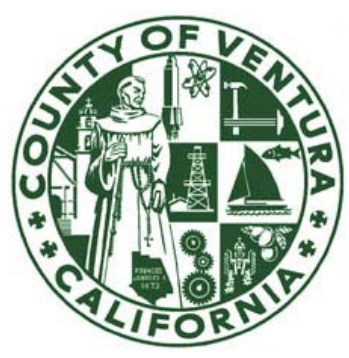

Office of

AGRICULTURAL COMMISSIONER

P.O. Box 889, Santa Paula, CA 93061

815 East Santa Barbara Street

Telephone: (805) 933-3165, (805) 647-5931

FAX: (805) 525-8922
Agricultural Commissioner

W. Earl McPhail

Chief Deputy

David Buettner

\section{County of Ventura Agricultural/Urban Buffer Policy - Revised 7/19/06}

The purpose of this policy is to protect the public health, safety and welfare of the citizens of Ventura County and protect the economic viability and long-term sustainability of the Ventura County agricultural industry.

New urban developments (and non-farming activities) should be required to lessen public and animal exposure to agricultural chemicals, dust, noise and odors and protect agricultural operations and land from vandalism, pilferage, trespassing and complaints against standard legal agricultural practices.

This Policy provides guidelines to prevent and/or mitigate conflicts that may arise at the agricultural/urban interface. It applies where urban structures or ongoing non-farming activities are permitted adjacent to land 1) in crop or orchard production; or 2) classified by the California Department of Conservation Important Farmland Inventory as Prime, Statewide Importance, Unique or Local Importance farmland. These guidelines apply to projects requiring discretionary approval by the county or a city where the proposed non-farming activity is abutting or on land zoned AE, OS or RA, and the farming activity is located outside a Sphere of Influence, as adopted by LAFCO. The Agricultural Policy Advisory Committee (APAC) or the Agricultural Commissioner may grant an exemption to these policies on a case-bycase basis, where physical factors prevent or alleviate the need for compliance.

Where applicable, urban developments or non-agricultural uses shall be conditioned to provide and maintain a 300-foot setback and chain-link fence on the non-agricultural property between the urban use and the agriculture, or a 150-foot buffer/setback if a vegetative screen as described below is used.

\section{APPLYING THE POLICY TO NEW DEVELOPMENT}

New dwellings, non-agricultural work sites and ongoing outdoor public activities potentially conflict with agricultural operations. A buffer/setback and fencing are therefore needed on these sites when they are developed adjacent to the qualifying agricultural land. A 300-foot setback to new structures and sensitive uses is required on the non-agricultural property unless a vegetative screen is installed. With a vegetative screen the buffer/setback is a minimum of 150-feet.

\section{Fencing requirements:}

A reinforced 8-foot chain link fence with top bar is required on applicable urban developments to deter pilferage and vandalism of crops. Placement is nearest the agricultural side. If the agricultural field has a fence, the requirement may be satisfied.

\section{Minimum standards for vegetative screen (shelter belt):}

- Two staggered rows of trees and shrubs characterized by evergreen foliage that extends from the base of the plant to the crown

- Trees and shrubs should be vigorous, drought tolerant and at least 6 feet in height at the time of installation

- Plants should have $50 \%$ to $75 \%$ porosity (i.e., approximately $50 \%$ to $75 \%$ of the plant is air space)

- Plant height should vary in order to capture drift within 4 feet of ground applications

- A mature height of 15 feet or more is required for trees 
- To ensure adequate coverage, 2 staggered rows should be located 5 feet apart and consist of minimum 5 gallon plants at least 6 feet tall planted 10 feet on center

- Recommended plants include: Toyon (Heteromeles arbutifolia), Sugarbush (Rhus ovata), Laurel sumac (Malosma laurina) and Italian cypress (Cupressus sempervirens)

- A long-term plan shall be in place for maintaining the vegetative shelter belt

\section{The following uses are acceptable within 300 feet of agriculture:}

- Parking lots and garages

- Landscaping/hardscape

- Storage sheds or open storage

- Greenhouse structures with venting away from the non-agricultural area

- Wooden or chain link fencing

- Some types of livestock such as range cattle or sheep (other livestock only as approved by APAC)

- Roads and drainage facilities

- Farmworker dwellings where notification between farmer and occupants can easily occur prior to spraying

- Low human-intensity uses as approved by APAC

The following uses are acceptable within 150 feet of agriculture with a vegetative screen (shelter belt):

- All uses acceptable within 300 feet

- Front yard setbacks

- Hiking, bike or bridle paths

- Single-use facilities for government, institutional or educational use where agreements and notification between parties can easily occur prior to spraying

- Farm and produce stands where notification between farmers and occupants can easily occur prior to spraying

- Agricultural Tourism in accordance with a Conditional Use Permit (CUP)

\section{APPLYING THE POLICY TO MODIFICATIONS OF EXISTING USES/ACTIVITIES}

- All Policy guidelines apply where feasible

The following apply where existing structures do not allow a 300-foot or 150-foot setback:

- Installation of a reduced vegetative screen

- Reinforced 8-foot chain link fence (minimum requirement)

- Information exchange for agricultural spraying notification

- Posting of Right-to-Farm Ordinance at the site of existing uses/activities

- Agreement to modify existing cooperative practices, if needed

The following apply where a school is located directly within 300 feet of agriculture:

- All K-12 school construction within 300 feet of agriculture requires a public meeting by APAC - and is strongly discouraged within $1 / 4$-mile of agriculture

- When a school is located directly within 300 feet of agriculture, the recommendations in Farming Near Schools, A Community Guide for Protecting Children (available from the Agricultural Commissioner's Office or www.agfuturesalliance.net) shall be followed by both the farmer and the school

These Guidelines were developed in part from data from Spray Drift Task Force (1997), established in response to EPA spray drift data requirements. 